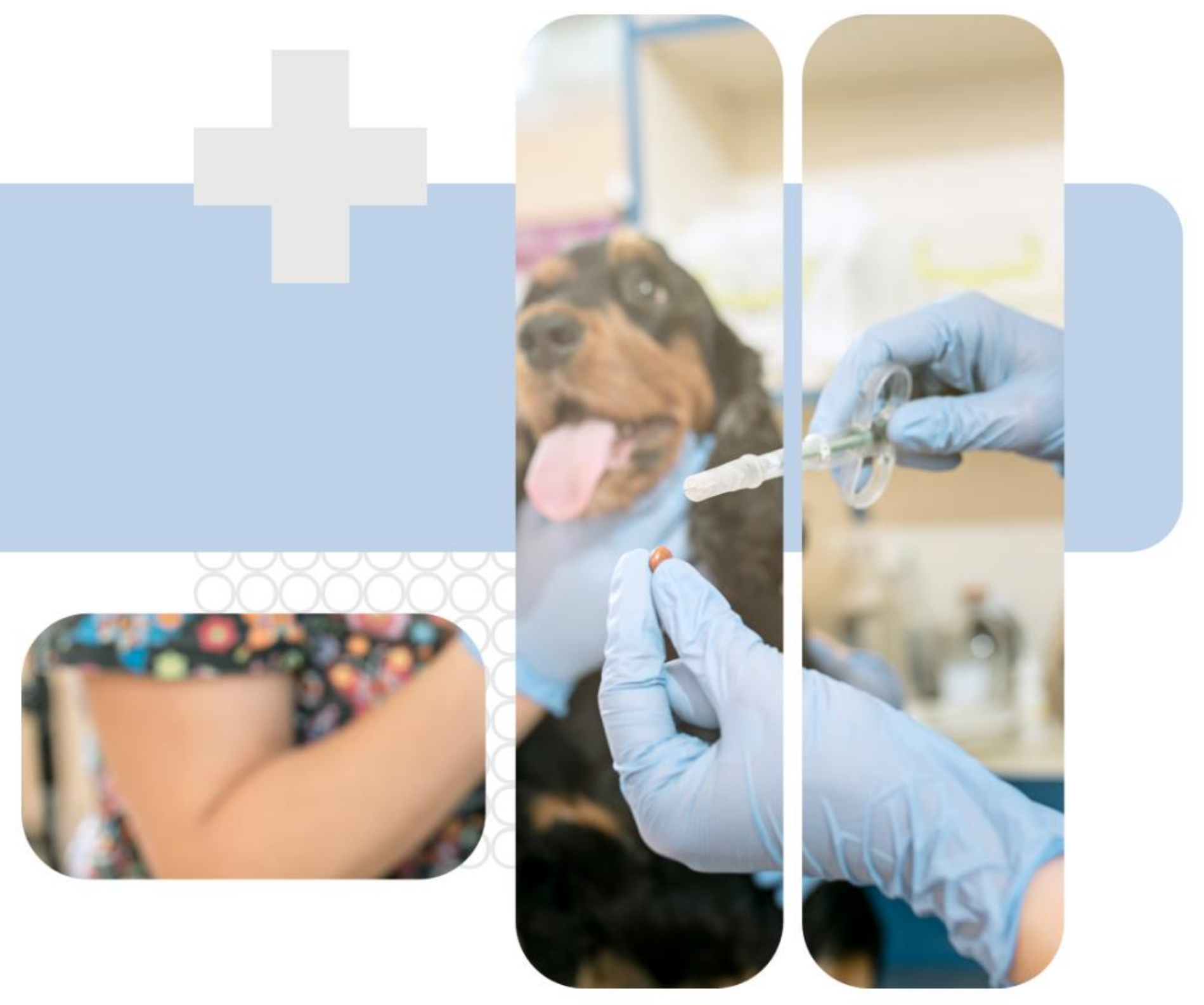

\title{
PRINCIPAIS DOENÇAS INFECCIOSAS E PARASITÁRIAS DE IMPORTÂNCIA EM MEDICINA VETERINÁRIA REVISÕES DE LITERATURA
}

ORGANIZADOR

ERIC MATEUS NASCIMENTO DE PAULA 


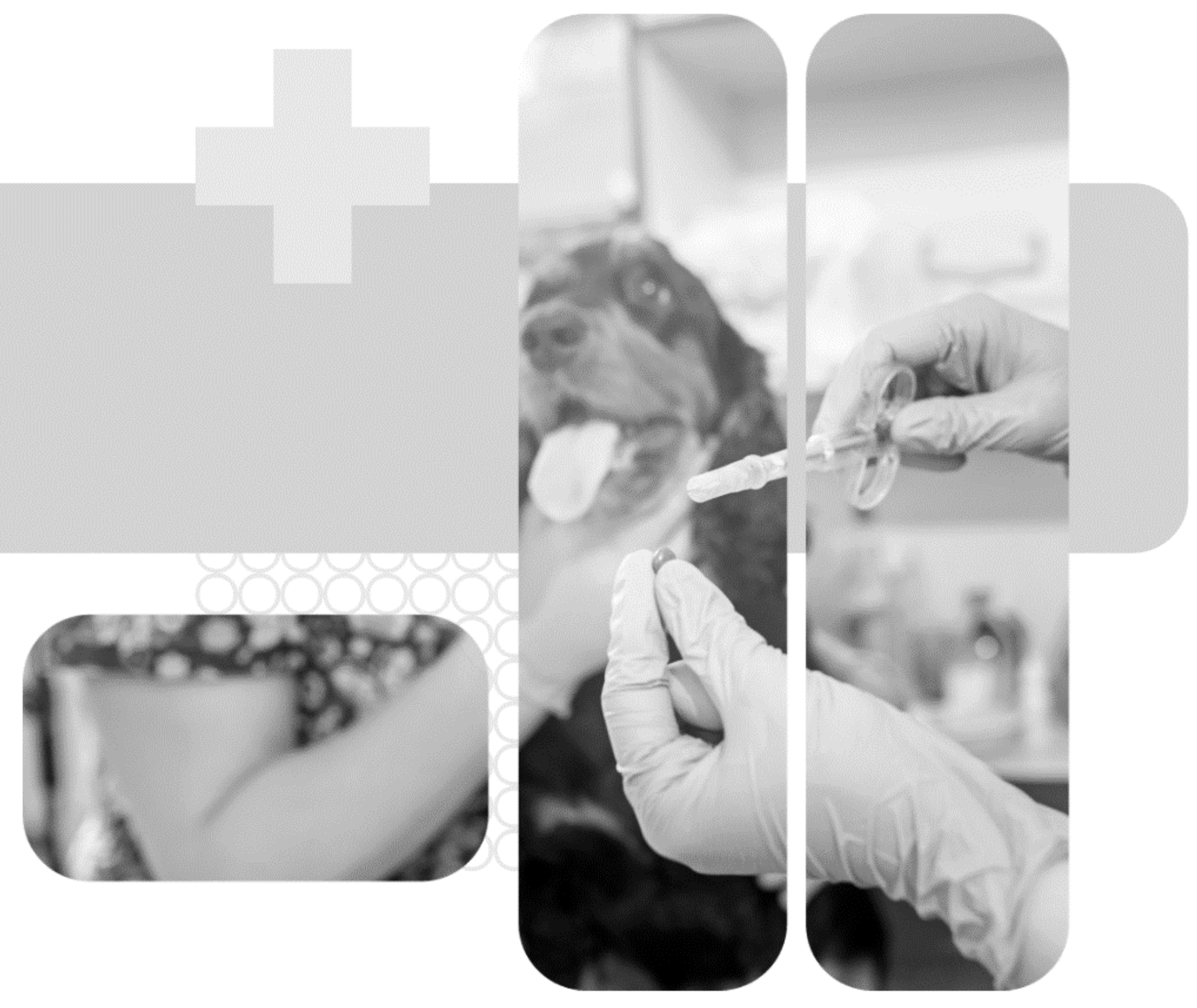

\section{PRINCIPAIS DOENÇAS INFECCIOSAS E PARASITÁRIAS DE IMPORTÂNCIA EM MEDICINA VETERINÁRIA REVISÕES DE LITERATURA}

ORGANIZADOR

ERIC MATEUS NASCIMENTO DE PAULA 


\section{Z}

2021 - Editora Amplla

Copyright @ Editora Amplla

Editor Chefe: Leonardo Pereira Tavares

Design da Capa: Editora Amplla

Diagramação: Yáscara Maia Araújo de Brito

Projeto Gráfico: Higor Costa de Brito

Principais doenças infecciosas e parasitárias de importância em medicina veterinária: revisões de literatura está licenciado sob CC BY 4.0.

(c) (i) Esta licença exige que as reutilizações deem crédito ao criador. Ele permite que os ou formato, mesmo para fins comerciais.

O conteúdo da obra e seus dados em sua forma, correção e confiabilidade são de responsabilidade exclusiva dos autores, não representando a posição oficial da Editora Amplla. É permitido o download da obra e o compartilhamento desde que sejam atribuídos créditos aos autores. Todos os direitos para esta edição foram cedidos à Editora Amplla.

ISBN: 978-65-88332-44-3

DOI: 10.51859/amplla.pdi443.1121-0

Editora Amplla

Campina Grande - PB - Brasil contato@ampllaeditora.com.br www.ampllaeditora.com.br 


\section{CONSELHO EDITORIAL}

Andréa Cátia Leal Badaró - Universidade Tecnológica Federal do Paraná Andréia Monique Lermen - Universidade Federal do Rio Grande do Sul Antoniele Silvana de Melo Souza - Universidade Estadual do Ceará Bergson Rodrigo Siqueira de Melo - Universidade Estadual do Ceará Bruna Beatriz da Rocha - Instituto Federal do Sudeste de Minas Gerais Caio César Costa Santos - Universidade Federal de Sergipe Carina Alexandra Rondini - Universidade Estadual Paulista Carla Caroline Alves Carvalho - Universidade Federal de Campina Grande Carlos Augusto Trojaner - Prefeitura de Venâncio Aires Carolina Carbonell Demori - Universidade Federal de Pelotas Cícero Batista do Nascimento Filho - Universidade Federal do Ceará

Clécio Danilo Dias da Silva - Universidade Federal do Rio Grande do Norte Daniela de Freitas Lima - Universidade Federal de Campina Grande Denise Barguil Nepomuceno - Universidade Federal de Minas Gerais Dylan Ávila Alves - Instituto Federal Goiano Edson Lourenço da Silva - Instituto Federal de Educação, Ciência e Tecnologia do Piauí Elane da Silva Barbosa - Universidade Estadual do Ceará Érica Rios de Carvalho - Universidade Católica do Salvador Gilberto de Melo Junior - Instituto Federal do Pará Higor Costa de Brito - Universidade Federal de Campina Grande Italan Carneiro Bezerra - Instituto Federal da Paraíba Ivo Batista Conde - Universidade Estadual do Ceará Jaqueline Rocha Borges dos Santos - Universidade Federal Rural do Rio de Janeiro Jessica Wanderley Souza do Nascimento - Instituto de Especialização do Amazonas João Henriques de Sousa Júnior - Universidade Federal de Santa Catarina João Manoel Da Silva - Universidade Federal de Alagoas João Vitor Andrade - Universidade de São Paulo Joilson Silva de Sousa - Instituto Federal do Rio Grande do Norte José Cândido Rodrigues Neto - Universidade Estadual da Paraíba Jose Henrique de Lacerda Furtado - Instituto Federal do Rio de Janeiro Josenita Luiz da Silva - Faculdade Frassinetti do Recife Josiney Farias de Araújo - Universidade Federal do Pará Karina de Araújo Dias - SME/Prefeitura Municipal de Florianópolis Laíze Lantyer Luz - Universidade Católica do Salvador Lindon Johnson Pontes Portela - Universidade Federal do Oeste do Pará Lucas Capita Quarto - Universidade Federal do Oeste do Pará Lúcia Magnólia Albuquerque Soares de Camargo - Unifacisa Centro Universitário Luciana de Jesus Botelho Sodré dos Santos - Universidade Estadual do Maranhão Luís Paulo Souza e Souza - Universidade Federal do Amazonas Luiza Catarina Sobreira de Souza - Faculdade de Ciências Humanas do Sertão Central Manoel Mariano Neto da Silva - Universidade Federal de Campina Grande Marcelo Alves Pereira Eufrasio - Centro Universitário Unifacisa Marcelo Williams Oliveira de Souza - Universidade Federal do Pará Marcos Pereira dos Santos - Faculdade Rachel de Queiroz Marcus Vinicius Peralva Santos - Universidade Federal da Bahia Marina Magalhães de Morais - Universidade Federal de Campina Grande Nadja Maria Mourão - Universidade do Estado de Minas Gerais Natan Galves Santana - Universidade Paranaense Nathalia Bezerra da Silva Ferreira - Universidade do Estado do Rio Grande do Norte Neide Kazue Sakugawa Shinohara - Universidade Federal Rural de Pernambuco Neudson Johnson Martinho - Faculdade de Medicina da Universidade Federal de Mato Grosso Patrícia Appelt - Universidade Tecnológica Federal do Paraná Paulo Henrique Matos de Jesus - Universidade Federal do Maranhão Rafael Rodrigues Gomides - Faculdade de Quatro Marcos 
Reângela Cíntia Rodrigues de Oliveira Lima - Universidade Federal do Ceará Rebeca Freitas Ivanicska - Universidade Federal de Lavras Renan Monteiro do Nascimento - Universidade de Brasília Ricardo Leoni Gonçalves Bastos - Universidade Federal do Ceará Rodrigo da Rosa Pereira - Universidade Federal do Rio Grande Sabrynna Brito Oliveira - Universidade Federal de Minas Gerais Samuel Miranda Mattos - Universidade Estadual do Ceará Shirley Santos Nascimento - Universidade Estadual Do Sudoeste Da Bahia Silvana Carloto Andres - Universidade Federal de Santa Maria Silvio de Almeida Junior - Universidade de Franca Tatiana Paschoalette Rodrigues Bachur - Universidade Estadual do Ceará Telma Regina Stroparo - Universidade Estadual do Centro-Oeste Thayla Amorim Santino - Universidade Federal do Rio Grande do Norte Virgínia Maia de Araújo Oliveira - Instituto Federal da Paraíba Virginia Tomaz Machado - Faculdade Santa Maria de Cajazeiras Walmir Fernandes Pereira - Miami University of Science and Technology Wanessa Dunga de Assis - Universidade Federal de Campina Grande Wellington Alves Silva - Universidade Estadual de Roraima Yáscara Maia Araújo de Brito - Universidade Federal de Campina Grande Yasmin da Silva Santos - Fundação Oswaldo Cruz Yuciara Barbosa Costa Ferreira - Universidade Federal de Campina Grande 


\section{ZIAMPLLA}

2021 - Editora Amplla

Copyright (c) Editora Amplla

Editor Chefe: Leonardo Pereira Tavares

Design da Capa: Editora Amplla

Diagramação: Yáscara Maia Araújo de Brito

Projeto Gráfico: Higor Costa de Brito

Dados Internacionais de Catalogação na Publicação (CIP)

Sueli Costa CRB-8/5213

Principais doenças infecciosas e parasitárias de importância em medicina veterinária [livro eletrônico] : revisões de literatura / organização Eric Mateus Nascimento de Paula. Campina Grande : Editora Amplla, 2021.

$233 \mathrm{p}$.

Formato: $\mathrm{PDF}$

ISBN : $978-65-88332-44-3$

1. Doenças zoonóticas 2. Doenças emergentes 3. Microbiologia ambiental 4. Agentes patogênicos I. Paula, Eric Mateus Nascimento de II. Título

\section{Índices para catálogo sistemático:}

1. Medicina veterinária : Doenças de animais 636.089

Editora Amplla

Campina Grande - PB - Brasil

contato@ampllaeditora.com.br www.ampllaeditora.com.br

\section{DAMPLLA}




\section{PREFÁCIO}

O objetivo principal deste livro é fornecer aos médicos veterinários e estudantes de veterinária uma revisão concisa dos fatos salientes das doenças infecciosas e parasitárias dos animais. Incluem-se as doenças causadas por bactérias, fungos, vírus e protozoários. Muitos textos sobre doenças infecciosas utilizam uma orientação sistêmica na apresentação do material. Isso geralmente resulta na sobreposição de discussões, pois várias doenças infecciosas afetam mais de um sistema. Pode-se então selecionar a doença ou doenças que deseja consultar por meio do sumário. As discussões sobre doenças são listadas em ordem alfabética.

O material é organizado e apresentado para referência rápida e, portanto, também é útil para técnicos de laboratório e estudantes de veterinária que tenham alguma dúvida sobre o assunto. A ênfase principal está nas doenças que mais acometem os animais no Brasil. A maioria dessas doenças também ocorre em outras partes do mundo, mas a extensão de sua ocorrência pode variar de uma região para outra. Um pequeno número de doenças pode ocorrer apenas em determinadas regiões geográficas. Essas doenças são discutidas, mas recebem menos ênfase.

O risco de exposição a agentes zoonóticos é inerente à prática da Medicina Veterinária. Este livro fornece também uma breve descrição de algumas zoonoses relevantes encontradas na rotina de Médicos Veterinários na prática de pequenos e grandes animais.

A ideia de desenvolver uma obra que aborde discussões sobre as doenças infecciosas e parasitárias no âmbito da Medicina Veterinária, versa sobre a missão que profissionais e acadêmicos da área têm de controlar a propagação e a gravidade dessas enfermidades por meio da criação e disseminação de conhecimentos, práticas e produtos. O presente livro, utiliza da estratégia de redes multidisciplinares ativas em áreas programáticas de alto impacto para disseminação dos conhecimentos.

O controle de doenças infecciosas e parasitárias em animais domésticos e silvestres requer uma compreensão da ecologia das enfermidades - as relações entre os hospedeiros animais e humanos, seus patógenos e o ambiente circundante. Esta obra está focada na ecologia e epidemiologia de doenças infecciosas e parasitárias, que inclui os estudos de doenças zoonóticas e emergentes, microbiologia ambiental e transmissão 
de agentes patogênicos através da cadeia alimentar (ou seja, segurança alimentar). Essas áreas são sinérgicas com áreas de mecanismos de resistência antimicrobiana, patobiologia, tratamento e prevenção de vírus, fungos, bactérias e protozoários de interesse em Saúde Única.

\section{Uma boa leitura a todos!}

Prof. Dr. Eric Mateus Nascimento de Paula

Docente do Curso de Medicina Veterinária do Centro Universitário de Mineiros - UNIFIMES

Bacharel em Medicina Veterinária pela Universidade Federal de Goiás - UFG Especialização em Epidemiologia e Saúde pela Universidade Federal de Goiás - UFG Especialização em Gestão da Sala de Aula no Ensino Superior pelo Centro Universitário de Mineiros - UNIFIMES Mestrado em Medicina Veterinária pela Universidade Estadual Paulista "Júlio de Mesquita Filho" - Unesp/FCAV Doutorado em Medicina Veterinária pela Universidade Estadual Paulista "Júlio de Mesquita Filho" - Unesp/FCAV 


\section{SUMÁRIO}

CAPÍTULO I - ABORTAMENTO EM BOVINOS NO BRASIL - PRINCIPAIS CAUSAS INFECCIOSAS E PARASITÁRIAS 9

DOI: 10.51859/AMPLLA.PDI443.1121-1

CAPITULO II - ADENITE EQUINA - IMPACTOS CLÍNICOS E EPIDEMIOLÓGICOS. .47

DOI: 10.51859/AMPLLA.PDI443.1121-2

CAPÍTULO III - BRUCELOSE BOVINA - ASPECTOS EPIDEMIOLÓGICOS E REPRODUTIVOS .67

DOI: 10.51859/AMPLLA.PDI443.1121-3

CAPÍTULO IV - CARBÚNCULO SINTOMÁTICO - DISCUSSÕES CLÍNICO-EPIDEMIOLÓGICAS 86

DOI: 10.51859/AMPLLA.PDI443.1121-4

CAPÍTULO V - CINOMOSE CANINA - ETAPAS DO PROCESSO SAÚDE-DOENÇA E PATOGENIA. 99

DOI: 10.51859/AMPLLA.PDI443.1121-5

CAPÍTULO VI - COINFECÇ̃̃O POR HEPATOZOON SP. E DIROFILARIA IMMITIS EM CÃES .122

DOI: 10.51859/AMPLLA.PDI443.1121-6

CAPÍTULO VII - COINFECÇOES POR HEMOPARASITAS EM CÃES. 137

DOI: 10.51859/AMPLLA.PDI443.1121-7

CAPÍTULO VIII - DERMATÓFILOS ISOLADOS DA PELE DE CÃES. .148

DOI: 10.51859/AMPLLA.PDI443.1121-8

CAPÍTULO IX - DOENÇA DE MAREK - ASPECTOS EPIDEMIOLÓGICOS .167

DOI: 10.51859/AMPLLA.PDI443.1121-9

CAPÍTULO X - ERLIQUIOSE MONOCíTICA CANINA - ABORDAGEM CLÍNICA E TERAPÊUTICA DA INFECÇÃO. .182

DOI: 10.51859/AMPLLA.PDI443.1121-10

CAPÍTULO XI - LEISHMANIOSE VISCERAL CANINA E SEUS ASPECTOS EM SAÚDE PÚBLICA .196 DOI: 10.51859/AMPLLA.PDI443.1121-11 CAPÍTULO XII - TRIATOMÍDEOS DO BRASIL E SUA IMPORTÂNCIA EM SAÚDE .212 


\title{
CAPÍ́TULO I
}

\section{ABORTAMENTO EM BOVINOS NO BRASIL - PRINCIPAIS CAUSAS INFECCIOSAS E PARASITÁRIAS}

DOI: $10.51859 /$ amplla.pdi443.1121-1

\author{
Vítor Lopes Barros ${ }^{1}$ \\ Vantuil Moreira de Freitas ${ }^{2}$ \\ Priscila Chediek Dall'Acqua ${ }^{2}$ \\ Eric Mateus Nascimento de Paula ${ }^{2}$
}

${ }^{1}$ Médico Veterinário Autônomo. Egresso do Curso de Medicina Veterinária do Centro Universitário de Mineiros UNIFIMES

${ }^{2}$ Docente do Curso de Medicina Veterinária do Centro Universitário de Mineiros - UNIFIMES.

\section{RESUMO}

A eficiência reprodutiva do rebanho está relacionada intimamente com a rentabilidade econômica do modelo de produção, fator importante para sequência da atividade pecuarista. Dentre as várias enfermidades que geram perdas, o abortamento é a que mais causa impacto, mas não a que mais causa prejuízo. $O$ abortamento ocorre entre os 42 e 280 dias de gestação por diversos fatores, como causas não infecciosas e infecciosas como vírus, protozoários, bactérias e fungos, e ainda por causas não especificas. Este trabalho trata-se de uma revisão bibliográfica sobre as principais causas de abortamento em bovinos. O objetivo deste trabalho é discutir as possíveis causas infecciosas e parasitárias de abortamento em bovinos, descrevendo a etiologia, epidemiologia, modo de transmissão, diagnóstico, tratamento e medidas de prevenção. Além de fazer um levantamento epidemiológico comparando dados antigos com os atuais entre regiões, revelando a incidência e os indicadores da prevalência dessas doenças. São vários os desafios dos profissionais a campo, como, animais falso negativos, persistentemente infectados, abortamentos esporádicos e o não diagnóstico etiológico. Saber a causa do abortamento é imprescindível e a complexidade está justamente no diagnóstico, muito por conta de a autólise fetal começar ainda no útero, e por existir múltiplas causas que levam ao abortamento, dificultando assim o diagnóstico. Vale salientar que somente 30 a $40 \%$ dos casos são atribuídos a uma causa específica, destes diagnósticos definitivos $80 \%$ são atribuídos às causas infecciosas. O conhecimento sobre essas causas, dados estatísticos, relevância econômica e impacto na saúde pública, favorecem a construção de formas de manejo e prevenção cada vez mais eficientes e direcionadas. Um manejo sanitário eficiente associado a um controle dos dados de cada animal, pode ajudar e muito nas tomadas de decisões e controle das falhas reprodutivas. Deve-se ter em mente que a vacinação é uma medida de controle muito importante, mas que sozinha não consegue ser totalmente eficiente, sendo necessário mais estudos como estes, para verificar a eficácia das medidas tomadas e se há ou não necessidade desta prática na 
propriedade, região e ou estado. Por fim, fica exposto a necessidade de conhecer a fundo as principais enfermidades reprodutivas, os métodos de controle e os pontoschaves de cada doença, sabendo que os impactos e perdas econômicas gerados estão muito além da perda fetal.

Palavras-chave: Abortamento. Causas infecciosas. Falhas reprodutivas. Levantamento epidemiológico.

\section{INTRODUÇÃO}

O Brasil tem um dos maiores rebanhos comerciais de bovinos do mundo, com cerca de 213,5 milhões de cabeças. A região Centro-Oeste é responsável por abranger 73,8 milhões dessas cabeças, o que significa 34,6 \% da criação nacional (IBGE, 2018), sendo a região com mais bovinos no Brasil. O destaque da região é o estado do Mato Grosso que detém o maior plantel com 30,2 milhões de cabeças. A atividade de bovinocultura de corte e de leite no Brasil é intensa, e após muitos anos de pesquisa e desenvolvimento, o país conseguiu tornar-se um dos maiores exportadores de carne bovina do mundo, exportando este produto para mais de 150 países (ABIEC, 2019).

A bovinocultura no Brasil ainda é em grande parte extensiva, mas com a redução da área destinada a pecuária pela crescente atividade da agricultura, a implementação de tecnologias e estudos da incidência de enfermidades que levam a diminuição da rentabilidade é imprescindível para tornar viável a criação de bovinos. As doenças reprodutivas influenciam e muito nos índices de natalidade, retorno ao cio, taxa de prenhez, natimortos e outros, gerando inúmeros impactos (JUFFO, 2010).

Com a economia voltada para a pecuária, a importância dos estudos de enfermidades que trazem perdas econômicas na criação de bovinos é inquestionável. Dentre as várias enfermidades que geram perdas, o abortamento é a que mais causa impacto, mas não a que mais causa prejuízo (JUFFO, 2010). O abortamento ocorre entre os 42 e 280 dias de gestação por diversos fatores, como causas não infecciosas e infecciosas como vírus, protozoários, bactérias e fungos, e ainda por causas não especificas (MASCARENHAS et al., 2019).

O desafio maior dos profissionais é distinguir as causas de abortamento para que assim o Médico Veterinário possa elaborar um plano de ação, pois, mesmo que os órgãos e placenta sejam encaminhados de forma correta aos laboratórios, deve-se ter em mente que o feto entra em processo de autólise ainda no útero antes do 
abortamento após sua morte, dificultando o diagnóstico em muitos casos (ORLANDO, 2013).

Existem diversas causas de abortamento, dentre as causas infecciosas podemos citar as doenças bacterianas (Brucelose, Leptospirose, Campilobacteriose), por protozoários (Neosporose e Tricomoníase), virais (Rinotraqueíte Infecciosa Bovina e Vírus da Diarreia Bovina). Vale salientar que somente 30 a $40 \%$ dos casos são atribuídos a uma causa específica, destes diagnósticos definitivos $80 \%$ são atribuídos às causas infecciosas (ANTONIASSI et al., 2013).

Os episódios de abortamento nos bovinos podem desencadear relevantes prejuízos econômicos, sanitários e eventualmente de saúde pública. A incidência de abortamentos no rebanho até $2 \%$ é considerada aceitável para bovinos; entretanto, acima de 3\% representa importância na investigação da possível causa. Contudo, menos da metade dos fetos bovinos abortados apresentam diagnóstico etiológico definido em virtude das múltiplas causas envolvidas (PAULA et al., 2014).

Portanto, a pesquisa e levantamento epidemiológico dessas causas se tornam valiosos, devido ser um problema reprodutivo comum, com epidemiologia e diagnóstico negligenciados e desconhecimento de muitos profissionais das diversas causas do abortamento. O objetivo deste trabalho é discutir as possíveis causas infecciosas e parasitárias de abortamento em bovinos, descrevendo a etiologia, epidemiologia, modo de transmissão, diagnóstico, tratamento e medidas de prevenção. Além de fazer um levantamento epidemiológico comparando dados antigos com os atuais entre regiões, revelando a incidência e os indicadores da prevalência dessas doenças.

\section{REVISÃO DE LITERATURA}

\subsection{Impactos e prejuízos dos abortamentos em bovinos no Brasil}

Na pecuária de leite e corte, a eficiência é o que define a continuidade da atividade e interesse dos produtores, para que o modelo continue sendo rentável a implementação de tecnologias, medidas preventivas, seleção genética e alimento ajustado são de suma importância (LOPES, 2013). A eficiência reprodutiva do rebanho está relacionada intimamente com a rentabilidade econômica do modelo de produção, fator importante para sequência da atividade pecuarista (OLIVEIRA et al., 2006). 
O abortamento em bovinos pode ser definido como a expulsão do feto vivo ou morto entre o $42^{\circ}$ dia e o $280^{\circ}$ dia de gestação, quando este é incompatível com a vida no meio extrauterino (MASCARENHAS et al., 2019). Este interfere no número de bezerros por ano, retarda o desenvolvimento genético e impacta economicamente os modelos de cria e recria (JUFFO et al., 2010; SILVA, 2016). No entanto, muitas causas de abortamento são infecciosas, provocando não apenas prejuízo econômico, mas impactos sanitários, podendo o feto abortado, placenta e anexos serem meios de transmissão para outros animais e seres humanos (ROMANI, 2012; JÚNIOR, 2017).

Muitas outras causas podem ser relacionadas as perdas gestacionais, 0 conhecimento sobre essas causas, dados estatísticos, relevância econômica e impacto na saúde pública, favorecem a construção de formas de manejo e prevenção cada vez mais eficientes e direcionadas. Um manejo sanitário eficiente associado a um controle dos dados de cada animal, pode ajudar e muito nas tomadas de decisões e controle das falhas reprodutivas (SILVA et al., 2017).

Segundo Antoniassi et al. (2007) e Juffo (2010), devido a múltiplas causas de abortamento, a coleta do material deve ser sistemática independente da suspeita inicial ou do diagnóstico presuntivo. Em caso de abortamento a placenta e seus anexos, o baço, rins, fígado, pulmão e conteúdo estomacal dos fetos são materiais de eleição utilizados para o diagnostico direto pelos testes de cultura e PCR (RUIBAL, 2009; SOLA et al., 2014).

\subsection{Causas de abortamento de origem infecciosa}

\subsubsection{Brucelose:}

As bactérias do gênero Brucella spp. pertencem ao filo Proteobacteria, e são classificadas como gram-negativas, aeróbicas, intracelulares que se apresentam em forma de bastonete (PROBERT et al., 2004; LICURGO, 2016).

A brucelose é considerada uma importante zoonose por acometer várias espécies de animais e ser potencialmente transmissível ao ser humano, sendo de interesse na saúde pública (LI et al., 2013; SOARES et al., 2015). Atualmente existem onze espécies do gênero Brucella (LPS, 2015), podendo apresentar espécies lisas ou rugosas. As bruceloses ocasionadas por espécies lisas são mais comuns nos humanos como Brucella abortus, $B$. suis e $B$. mellitensis sendo consideradas mais patogênicas aos hospedeiros (BRASIL, 2006; SOLA et al., 2014). 
A B. abortus não é a mais patogênica e não é a que possui maior potencial zoonótico entre as Brucellas spp. (WHO, 2006; PAULIN; FERREIRA NETO, 2008), no entanto torna-se uma bactéria de relevância por ser difundida nos rebanhos e muitas vezes subdiagnosticada. Os seres humanos podem contrair a enfermidade pelo consumo do leite e seus subprodutos que não foram submetidos a etapa de pasteurização ou fervura do leite, e pelo contato direto com os materiais do abortamento (BRASIL, 2006; JÚNIOR, 2017).

A brucelose bovina, causada pela B. abortus, possui grande influência negativa nas taxas reprodutivas, e tem papel importante na saúde pública por ser uma zoonose (TERRA, 2017; JÚNIOR, 2017). Segundo Brasil (2010) a maioria dos casos humanos de brucelose está relacionada a B. abortus no país. Os grupos mais afetados são pessoas da área rural, principalmente da pecuária leiteira, Médicos veterinários, e trabalhadores de frigoríficos que entram em contato com fetos e seus anexos, sangue, vísceras e a própria carcaça que são fontes de infecção (CARDOSO; COSTA, 2011).

A brucelose se difunde nos rebanhos pela obtenção de animais positivos, sendo transmitida para outros animais de forma horizontal ou vertical (RADOSTITS et al., 2006; MONTES, 2017). A forma horizontal é a mais comum e ocorre pelo contato via oronasal com as secreções do abortamento ou parto, pastagem e água contaminados. Os hábitos de cheirar e lamber os recém-nascidos e os anexos fetais, contribuem para a disseminação (LAGE et al., 2008; ROMANI, 2012). Os machos reprodutores positivos devem ser descartados pois a bactéria pode ser encontrada no sêmen, a transmissão por cópula dificilmente ocorre pelas barreiras naturais da vagina, no entanto pela inseminação artificial a infecção se torna facilitada pelo sêmen ser depositado diretamente no útero (PAULIN; FERREIRA NETO, 2003; LAGE et al., 2008). A infecção via vertical ocorre durante a gestação, durante o parto, ou por consumo de colostro e leite pelo recém-nascido (PAULIN; FERREIRA NETO, 2008; BARBOSA, 2014).

Os pesquisadores Chate et al. (2009), encontraram resultados elevados da brucelose com prevalência de $41,5 \%$ de propriedades foco e $8,55 \%$ de animais positivos no Mato Grosso do Sul. No entanto em um estudo também realizado no Mato Grosso do Sul por Leal Filho et al. (2016), constatou consecutivamente propriedades foco e animais positivos $39,1 \%$ e $8,9 \%$ na região do Pantanal, na região do Planalto $25,3 \%$ e $6,1 \%$, e para região do Planalto Norte $32,1 \%$ e 6,4\%, mostrando que medidas de controle 
impostas pelo PNCEBT estão surtindo efeito vagarosamente, e que pesquisas devem ser constantemente atualizadas para que os índices se tornem menos defasados e mais confiáveis.

Em Goiás Rocha et al. (2009), encontraram 17,54\% (145/895) de propriedades foco e 3,01\% (240/10.738) animais positivos. Na pesquisa de Montes (2017), na região do Rio das Antas, Goiás, evidenciou que 13 das 95 (16,68\%) propriedades eram foco de brucelose e 21 dos 992 (2,11\%) animais acima de 24 meses analisados eram positivos. Esses dados quando comparados também demonstraram efeito positivo das medidas de controle e erradicação impostas pelo PNCEBT.

A principal sintomatologia em fêmeas positivas é o abortamento a partir do $5^{\circ}$ mês de gestação em animais não imunizados e susceptíveis. Nas gestações seguintes há maiores chances de nascimento de animais fracos e debilitados, podendo ocorrer subfertilidade, infertilidade, aumento do período de serviço, diminuição da taxa de concepção, retenção de placenta e infecções uterinas (BANDEIRA, 2011; TERRA, 2017). Os sinais clínicos em humanos podem ser inespecíficos ou mesmo não existir, mas pode levar a esterilidade e ser facilmente confundida com outras doenças (LAWINSKY et al., 2010).

O Programa Nacional de Controle e Erradicação da Brucelose e Tuberculose (PNCEBT) criado em 2001, estabelece o teste de antígeno acidificado tamponado (ATT) também conhecido teste de rosa bengala, e teste do anel em leite (TAL) como de eleição para triagem, e os testes 2 Mercaptoetanol (2M) e fixação de complemento (FC) como confirmatórios (BRASIL, 2006). O entrave no diagnóstico da brucelose é os falsopositivos e os falso-negativos, pois fêmeas vacinadas com a B19 em época errada são reagentes positivas (ALVES, 2011), mas Organização Mundial de Saúde Animal (OIE) introduziu a RB51 como alternativa do controle da zoonose, uma vacina que não reage aos testes de aglutinação de anticorpos e que pode ser utilizada em qualquer idade a partir de terceiro mês de vida (MONTES, 2017).

Desde a criação do PNCEBT, pelo MAPA, uma das medidas profiláticas para o controle da brucelose é a vacinação obrigatória em todos os estados brasileiros de fêmeas com idade entre 3 e 8 meses. Atualmente existem duas vacinas opcionais a B19 e a RB51 implantada no programa em 2017. Ainda como profilaxia têm-se a identificação de propriedades livres, monitoramento de rebanhos com testes de eleição, transporte 
de animais com Guia de Trânsito Animal (GTA), abate sanitário dos animais positivos aos testes confirmatórios e destino correto das carcaças e fetos abortados, bem como desinfecção correta dos objetos e ambiente. A introdução de animais com histórico desconhecido é um risco, devendo-se realizar o diagnóstico preventivo com antecedência para garantir que a brucelose não se instale em rebanhos livres. (BRASIL, 2006; POESTER et al., 2009; MAPA, 2017).

\subsubsection{Leptospirose}

A leptospirose é causada por uma bactéria gram-negativa e helicoidal, do gênero Leptospira spp., sendo a espécie L. interrogans de importância patogênica. Estima-se a existência de aproximadamente 250 sorovariedades desta espécie. Os sorovares Wolffi, Hardjo e Pomona são os mais encontrados em bovinos (LOMAR et al., 2005; PAES, 2018). Segundo os autores Adler e Moctezuma (2010), as sorovariedades são classificadas de acordo com sua estrutura de epítopos em um mosaico de lipopolissacarídeo (LPS) de antígenos, e sua especificidade depende da composição estrutural e do açúcar que o compõe.

A leptospirose é uma zoonose de distribuição mundial, relacionada principalmente a países com condições tropicais e subtropicais, que oferecem altas temperaturas e umidade. A ocorrência dessa doença em bovinos está relacionada a locais próximos a lavouras, pela propagação de roedores, ou em regiões com extensões de áreas alagadas, onde a bactéria pode persistir por até 180 dias. Ainda é descrita a possibilidade de interação entre animais silvestres e bovinos, bem como a falta higiene e controle dos roedores durante o armazenamento dos alimentos (RADOSTITS et al., 2006; MIASHIRO et al., 2018).

As pesquisas de Pasqualotto; Sehnem e Winck (2015) na região oeste de Santa Catarina, obtiveram uma incidência de 31,67\% (229/723) amostras positivas para Leptospira spp, as amostras de sangue foram coletadas entre 2011 e 2012, o estudo foi focado em bovinos leiteiros e é uma das poucas fontes de informação daquela região. Em 2019 Santana (2019) realizou um estudo focado em uma única propriedade localizada no município de Sacramento (MG), sendo coletado 100 amostras do rebanho leiteiro onde 11 destas testaram positivo para leptospirose, ou seja, uma ocorrência de $11 \%$, resultado este considerado baixo comparando com outros autores. 
A leptospirose se mostrou ocorrente mesmo em animais da raça Curraleiro e Pantaneiro, em 2012 foi feito um estudo por Romani (2012) com 1280 amostras provenientes de 20 propriedades dos estados de Goiás, Tocantins e Piauí, o resultado foi uma ocorrência de 44,8\% (573 amostras positivas) para a raça curraleiro. O mesmo estudo coletou também 248 amostras da raça pantaneiro de quatro propriedades dos estados de Mato Grosso e Mato Grosso do Sul, testando 121 amostras positivas, ou seja, $51,2 \%$ dos animais apresentaram reação sorológica. Observou-se que $100 \%$ dos criatórios testados tiveram pelo menos um animal positivo para Leptospira spp. Um outro estudo no pantanal foi analisado 246 propriedades e 2.766 animais. A prevalência obtida nos animais foi de $66 \%(1.826 / 2.766)$, e $98 \%(241 / 246)$ dos rebanhos testados tinham pelo menos um animal positivo para Leptospira spp. (MIASHIRO et al., 2018). Estes resultados mostram a alta ocorrência da leptospirose no pantanal, devido as condições ambientais favoráveis como a elevada temperatura e áreas alagadas (GENOVEZ, 2018; MIASHIRO et al., 2018).

Em um estudo mais abrangente, Bastos et al. (2016) encontraram 821 amostras positivas das 1.300 coletadas de seis estados brasileiros (Goiás, Maranhão, Minas Gerais, São Paulo, Sergipe e Tocantins), uma ocorrência de 63,1\%. Resultados condizentes com os apresentados por Miashiro et al. (2018) no pantanal.

Os animais infectados eliminam o agente etiológico na urina contaminando fômites, alimentos, água e solo. (ROLIM et al., 2012). Segundo Machado; Coelho; Rezende (2010) a bactéria também é potencialmente eliminada pelos bovinos durante as descargas uterinas após o abortamento, placenta e feto, e pelo sêmen de touros. Os bovinos em lactação eliminam a bactéria no leite durante a fase aguda sistêmica (SIMÕES et al., 2016). A infecção ocorre após o contato direto pela monta natural ou inseminação artificial, e de forma indireta com o ambiente contaminado, como bebedouros, poças de água e comedouros (GOMES, 2015). A penetração do agente acontece através da pele lesionada ou integra e pelas mucosas, se multiplicando no sangue e linfa, posteriormente se espalha para órgãos como pulmões, fígado, baço, rins e sistema reprodutor através da via sanguínea desencadeado pelo quadro de leptospiremia (SIMÕES et al., 2016; GENOVEZ, 2018).

A leptospirose pode se apresentar de três formas: aguda, subaguda e crônica (RADOSTITS et al., 2006). A fase aguda geralmente ocorre em animais jovens, podendo 
apresentar hipertermia, hemólise intravascular, nefrite, hemoglobinúria, anemia, icterícia, e mastite com redução significativa da produção de leite podendo levar a morte (ROLIM et al., 2012; ROMANI, 2012). Em casos subclínicos, o animal não apresenta sintomatologia, sendo mais comum em animais adultos que desenvolveram imunidade após o contato, no entanto continuam a eliminar o agente de maneira intermitente no ambiente contribuindo para disseminação (RADOSTITS et al., 2006). Romani (2012) cita a forma crônica como a mais importante economicamente por causar abortamentos, infertilidade, nascimento de animais fracos ou natimortos, além dos gastos com medicamentos, mão de obra veterinária, e maior número de inseminações se considerarmos as tecnologias atuais. Segundo Teixeira (2019), a perda gestacional ocorre geralmente no 5으 e 6으 mês de gestação.

O histórico de abortamento e problemas reprodutivos são necessários para uma suspeita da presença de leptospirose no rebanho (FÁVERO et al., 2017), acompanhado de dados epidemiológicos da região e presença de fatores sugestíveis a aparição da doença, como áreas alagadas e presença de roedores (GENOVEZ, 2018).

Entre os métodos de diagnósticos para a leptospirose, podemos citar os que buscam encontrar anticorpos da bactéria, e os que buscam o DNA do antígeno ou a própria bactéria em fluidos e tecidos. O teste sorológico considerado padrão é o SAM (Soroaglutinação Microscópica), em que os anticorpos reagem aos antígenos vivos formando aglutinações visíveis ao microscópio de campo escuro (LEVETT, 2004; ROMANI, 2012; SANTANA, 2019). O teste de ELISA (Ensaio Imunoenzimático) e imunofluorescência direta também podem ser utilizados como formas alternativas, este último é feito através de imprints dos rins, pulmão, fígado e ou placenta (ANTONIASSI et al., 2007).

O controle da doença se baseia no tratamento dos animais infectados com estreptomicina, antibiótico de eleição que visa impedir a septicemia e futura contaminação do ambiente, mas a principal forma de profilaxia é a vacinação, indicada para locais onde a enfermidade é prevalente (JUFFO, 2010).

\subsubsection{Campilobacteriose}

O agente causador da campilobacteriose é uma bactéria que possui duas subespécies, a Campylobacter fetus subsp. venerealis relacionado a campilobacteriose 
genital bovina (CGB) (PELLEGRIN, 2001; JAGUSZESKI et al., 2017), e a Campylobacter fetus subespécie fetus que pode causar abortamentos esporádicos em bovinos e infertilidade em ovinos (ZIECH et al. 2014). A C. fetus subsp. venerealis é um bastonete gram-negativo, em formato de vírgula ou em "S", espiralado, não formador de esporos e com um ou dois flagelos polares (ALVES et al., 2011).

Nas últimas décadas a prevalência de abortamentos por Campilobacteriose nos rebanhos brasileiros tem se mostrado elevada (NASCIMENTO; SANTOS, 2011). Frias et al. (2017) não constataram a presença de Campylobacter fetus em reprodutores de alta genética no estado de Mato Grosso do Sul, foram 210 amostras coletadas e o resultado foi negativo para todas as amostras de esmegma. Este conflitou resultados obtidos por autores como Ziech et al. (2014) que encontraram 9\% da bactéria entre as 816 amostras que se distribuíam em coletada de esmegma (480 amostras), aspirados de muco cervical (324 amostras) e aspirados de conteúdo abomasal de fetos bovinos abortados (12 amostras), este estudo foi realizado na região do Rio Grande do Sul entre 1999-2010. Já Botelho (2014) detectou o patógeno em 17,5\% das amostras coletadas de touros enviados para um abatedouro situado na região sul de Minas Gerais.

Leal et al. (2012) realizaram um estudo em um abatedouro e locais próximos na região do Distrito Federal, a ocorrência de C. fetus foi considerada elevada, pois 44 animais testaram positivo dos 398 animais, ou seja, uma ocorrência de 11,1\% de animais positivos. Dentre as 258 amostras de fêmeas 27 foram reagentes, e das 140 dos machos 17 deram positivas. Apesar dos resultados terem sido considerados elevados, este estudo é concomitante com resultados apresentados anteriormente por Botelho (2014) e Ziech et al. (2014) embora em regiões distintas, sendo que Botelho (2014) obteve a maior porcentagem de prevalência.

Na região de Pernambuco Oliveira et al. (2015) pesquisaram a presença da bactéria Campylobacter fetus spp venerealis e encontraram uma prevalência de 1,8\% (7/383). A pesquisa foi abrangente, e usou amostras de 21 rebanhos entre 19 municípios. O resultado foi abaixo do esperado, no entanto, foram resultados próximos aos de Frias et al. (2017) no estado do Mato Grosso do Sul.

A CGB é uma doença de distribuição cosmopolita que traz prejuízos reprodutivos e perdas econômicas. É disseminada de forma venérea dos touros para vacas e viceversa durante a cópula (ALVES et al., 2011; ZIECH et al. 2014), mas podendo ser 
transmitido pela inseminação artificial com utilização de sêmen ou material contaminado (RIET-CORREA et al., 2007). Cerca de 30\% das vacas infectadas tornam-se portadoras (QUINN et al., 2005). Os touros com mais de cinco anos de idade se tornam portadores assintomáticos e importantes disseminadores após sua infecção, enquanto touros jovens podem se infectar e ocorrer cura de forma espontânea (RIET-CORREA et al., 2007).

Nos machos, ocorre colonização da mucosa do prepúcio, estando a bactéria presente apenas no meio externo; não sendo de caráter invasivo e não induzindo a produção de anticorpos (ZIECH et al., 2014). Nas fêmeas o agente coloniza a mucosa vaginal, cervical e dos ovidutos (PELLEGRIN, 2001; JAGUSZESKI et al., 2017), afetando o tecido epitelial do útero (CHIAPPARRONE et al., 2011).

Os sinais clínicos são observados somente nas vacas, podendo ocorrer endometrite, prolongado intervalo entre partos, repetição de cio, salpingite, ciclos longos, e rebanhos apresentando baixa produtividade (LEAL et al., 2012), associados principalmente a novilhas ou vacas jovens que não receberam imunização prévia. 0 abortamento ocorre em cerca de $10 \%$ dos animais acometidos, entre o quarto e o sétimo mês de gestação (PELLEGRIN, 2001; ALVES et al., 2011).

A suspeita da presença da enfermidade se dá pela ocorrência de distúrbios reprodutivos associados aos fatores epidemiológicos e de risco, utilização de touros velhos para a cópula, ou repasse. O diagnóstico laboratorial pode ser feito pelo teste de imunofluorescência direta que constata a presença do agente no material muco cervical, ou por meio da cultura bacteriana, que tem resultados melhores a partir da coleta do esmegma do prepúcio de touros, fazendo a aspiração com a pipeta de inseminação (HIRSH; ZEE, 2009; ALVES et al., 2011). Em casos de abortamentos, o conteúdo do abomaso e fragmentos do pulmão e do fígado do feto são de eleição para o isolamento bacteriano. O PCR também pode ser utilizado como meio de diagnóstico (JUFFO, 2010).

O tratamento da CGB é de alto custo, sendo indicado para animais de alto valor zootécnico, como animais doadores de sêmen e embrião. Segundo Alves et al. (2011), o uso de sulfato de dihidroestreptomicina na dosagem de $22-25 \mathrm{mg} / \mathrm{kg}$ por via intramuscular ou subcutânea no primeiro, terceiro e quinto dia, e aplicação diretamente no pênis e prepúcio de uma solução contendo $5 \mathrm{~g}$ de sulfato de dihidroestreptomicina no segundo e quarto dia de tratamento, demonstraram efeitos satisfatórios. 
A principal forma de controle é a implementação da biotecnia de inseminação artificial, que substitui o contato sexual, eliminando a principal forma de transmissão (BONDURANT, 2005; RIET-CORREA et al., 2007; ALVES et al., 2011). Evitar a utilização de touros de repasse, descartar fêmeas vazias e/ou positivas ao final do período de monta (PELLEGRIN et al., 2002), descarte de touros com mais de cinco anos, são fatores importantes para a mantença do rebanho livre, bem como a aquisição de animais negativos (BONDURANT, 2005; RIET-CORREA et al., 2007). A vacinação de vacas pode ser implementada como forma de prevenção e controle nos rebanhos, mesmo em locais endêmicos e com altas taxas de infecção a proteção imunológica têm sido muito eficiente (BONDURANT, 2005; FRIAS et al., 2017).

\subsubsection{Rinotraqueíte Infecciosa Bovina}

O herpesvírus bovino tipo 1 (BHV-1) é o agente relacionado a Rinotraqueite Infecciosa Bovina (IBR) pertence ao complexo herpesvírus bovino, é causador de abortamento e outras enfermidades em bovinos (ANTONIASSI et al., 2007). Etiologicamente é um vírus envelopado pertencente à família Herpesviridae, Subfamília Alphaherpesvirinae e Gênero Varicellovirus (MUYLKENS et al., 2007).

Em São Paulo Crespo et al. (2016) evidenciaram que 100\% dos 12 touros de uma propriedade apresentavam anticorpos contra o BoHV-1, isto foi constatado pela técnica de vírus neutralização (VN). A sorologia apesar de não ser a ferramenta ideal para o diagnóstico etiológico demonstra a presença da enfermidade reprodutiva nos rebanhos, inclusive em infecções latentes (FINO et al., 2012). No estado de Espírito Santo, estudos encontraram $66,8 \%$ de amostras positivas entre os 59 rebanhos leiteiros não vacinados dos 23 municípios avaliados (SANTOS et al., 2014).

Dados do início do século 20 mostraram uma soropositividade de $83 \%$ segundo Vieira et al. (2003) e 51,9\% perante Barbosa et al. (2005) nos rebanhos da região CentroOeste. Urzêda e colaboradores (2018) detectaram uma soroprevalência de 96,4\% (55/57) dos animais testados em Goiás, na microrregião Vale do Rio dos Bois. Esse resultado difere dos apresentados anteriormente, isso se deve ao fato dos animais terem passado por uma análise clínica, selecionando os mesmos com histórico de problemas reprodutivos e sintomas sugestivos. Complementando, estudos nos estados 
de Goiás e Rio Grande do Sul com amostras de sêmen fresca, revelaram 44,7\% de positividade para o BoHV-1 (OLIVEIRA et al., 2011).

No estado do Mato Grosso Quinteiro (2016) avaliou 99 touros de oito diferentes propriedades de seis das sete macrorregiões do estado, este estudo recente achou 21,2\% (21/99) de amostras de sêmen positivas do genoma BoHV-1 pelo teste PCR, constatando a infecção viral e que o patógeno estava sendo excretado pelo sêmen no momento da coleta. A eliminação do vírus pelo sêmen constitui um importante via de transmissão da infecção entre os rebanhos, sendo importante ter conhecimento sobre o estado dos touros quanto a infecção pelo BoHV-1 antes da utilização destes na reprodução, seja para monta natural ou coleta de sêmen para a inseminação artificial (QUINTEIRO, 2016).

Na região Oeste do Estado do Paraná 1930 fêmeas com idade $\geq 24$ meses, providas de 295 rebanhos não vacinados contra o BoHV-1, foram submetidas ao teste de ELISA-indireto verificando uma prevalência de $64,41 \%$ (190/295) de foco entre as propriedades (DIAS et al., 2008). Vale ressaltar que a coleta das amostras foi feita no período de dezembro de 2001 a julho de 2002. Já Dias et al. (2013) verificaram 71,3\% de propriedades foco, sendo encontrado $59,0 \%$ das fêmeas soropositivas também no estado do Paraná.

Na bacia leiteira da Ilha de São Luís-MA região Nordeste, 156 animais de 16 propriedades foram submetidos a técnica de ELISA-indireto, o teste sorológico revelou 67,5\% de positividade, ou seja, 108 das 156 das amostras analisadas apresentaram anticorpos contra o BHV-1, ainda foi testemunhado que $100 \%$ das propriedades analisadas possuíam pelo menos um animal positivo, sendo propriedades foco (SOUSA et al., 2011). Segundo Bezerra et al. (2012) o BoHV-1 está amplamente distribuído pelas regiões do Brasil, resultando em elevados índices de infecção nos rebanhos.

A infecção pode ocorrer pelo contato direto entre as mucosas nasais, por aerossóis, pela monta natural ou inseminação artificial com sêmen contaminado (VIU et al., 2014), e transferência de embrião com o vírus aderido à zona pelúcida ou meios de cultura contaminados (RUFINO; SENEDA; ALFIERI, 2006). Após a infecção o agente entra em um período de latência, que é interrompido após a queda da imunidade, seja pelo parto, estresse ou uso prolongado de corticoides, secretando o vírus pelos líquidos genitais e nasais, tornando o animal um disseminador intermitente (TERRA, 2017). 
Pituco (2009) afirma que diversas enfermidades podem levar aos sinais respiratórios e reprodutivos o que dificulta o diagnóstico da IBR nos rebanhos. Segundo Terra (2017) os abortamentos seguidos de retenção de placenta são sinais sugestíveis e ocorrem após o sexto mês de gestação. No curso agudo da doença, o herpesvírus bovino tende a aparecer como vulvovaginite, conjuntivite e rinotraqueíte. Mumificação, nascimentos de bezerros fracos e natimortos, são sinais comuns em casos de infecção por BHV-1.

Durante o curso agudo aos quais os animais apresentam evidências clínicas da infecção viral, pode-se coletar amostras de secreções oculares, nasais, vaginais, de prepúcio ou de áreas com lesões evidentes utilizando swabs (COSTA et al., 2017). Em fetos abortados fragmentos dos rins, fígado e dos pulmões podem ser coletados e encaminhados (FRANCO; ROEHE, 2007; OIE, 2009). O teste de isolamento em cultivo celular é o melhor para o diagnóstico viral, sendo considerado "padrão ouro", no entanto requer um exame confirmatório por meio de ensaios de imunofluorescência ou imunoperoxidase (FLORES; CARGNELUTTI, 2012). O PCR também pode ser utilizado, entretanto, não se consegue detectar o vírus latente se as amostras não forem de locais de latência ou também denominados de sítios de latência (gânglio sacral e trigêmeo principalmente) (TERRA, 2017).

De acordo com Hamzé et al. (2011) o prognóstico é favorável nos casos com sinais respiratórios. O tratamento é apenas sintomático, visando controlar infecções secundárias com utilização de antibióticos de amplo espectro, antiinflamatórios, antitérmicos e mucolíticos (VIU et al., 2014).

Para a erradicação da doença pode ser adotado o abate dos animais soropositivos, e algumas vezes até dos animais saudáveis, pois mesmo que curados clinicamente eles podem estar em período de latência e eliminar o vírus no ambiente quando a imunidade abaixar (ACKERMANN; ENGELS, 2006). Porém, por ser uma alternativa custosa se torna pouco viável, sendo mais efetivo o uso de medidas preventivas como a imunização prévia evitando perdas econômicas (PATEL, 2005).

Os autores Franco e Roehe (2007), recomendam duas estratégias de controle, com o sem utilização da vacina: um programa de vacinação deve ser feito em propriedades com elevada porcentagem de aquisição de animais, propriedades com histórico positivo da enfermidade, rebanhos com sorologia elevada e sistemas de recria 
e confinamento que reúnem novilhos de várias procedências. Nos rebanhos que não possuem histórico de problemas reprodutivos e sinais clínicos do complexo, a vacinação não precisa ser empregada, no entanto, o monitoramento deve ser constante dos parâmetros clínicos e reprodutivos. A vacina pode ser utilizada a partir dos 6 meses de idade, deve-se fazer a segunda dose 28 dias após a primeira, é necessário ainda o reforço anual, e sendo indicada sua utilização antes da estação reprodutiva (VIU et al., 2014).

No Brasil são comercializadas e autorizadas vacinas com vírus inativado ou termossensível (atenuada). O uso de vacinas atenuadas pode resultar em possíveis infecções latentes nos animais vacinados (JONES; CHOWDHURY, 2008; JONES; DA SILVA; SINANI, 2011). Segundo Jones; Da Silva; Sinani, (2011), as vacinas inativadas não são capazes de causar infecção latente nos animais e não provocando nenhum sinal clínico como o abortamento, podendo ser usada em gestantes. No entanto, vacinas inativadas não são efetivas na proteção primaria do bezerro concedida apenas pela colostragem (MOREIRA et al., 2001). De acordo com Pituco (2009), as vacinas atenuadas e inativadas conseguem prevenir a aparição dos sinais clínicos e reduzir a liberação do vírus no ambiente, mas não evitar a infecção. Mas por meio de estudos, Newcomer et al. (2017), observaram que ambas as vacinas, seja inativada ou atenuada, diminuem o risco de abortamento.

Nos rebanhos com alta prevalência a utilização de vacina com marcador genético é a melhor opção, conseguindo diferenciar os animais infectados naturalmente e os vacinados pelo teste de ELISA. No entanto essa vacina não está autorizada a ser utilizada no Brasil (COSTA et al., 2017).

\subsubsection{Diarreia Viral Bovina (BVD)}

O Vírus da Diarreia Viral Bovina (BVDV) é encontrado no mundo todo e é relatado no Brasil desde 1960 (ANTONIASSI et al., 2007). Pertence à família Flaviviridae, gênero Pestvirus, possui RNA de fita simples e é classificado perante seu efeito citopatogênico e não citopatogênico nas células, e ainda por sua capacidade antigênica em 1 e 2 (RIETCORREA et al., 2007; CANÁRIO et al., 2009). Apesar de ter importância reprodutiva, esse também pode levar a sinais clínicos referentes ao sistema respiratório e gastrointestinal (BRITO et al., 2010). 
Quando fêmeas prenhes se infectam entre 90 e 120 dias de gestação pelo vírus não citopatogênico, o feto se torna persistentemente infectado (PI) não reconhece o vírus e não forma anticorpos (FULTON et al., 2005). Animais PI são a principal fonte de contaminação, eliminando o vírus de forma contínua pelas secreções nasais e oculares, saliva, leite, sêmen, urina e fezes (TERRA, 2017), deve ser considerado o ponto-chave da enfermidade, por contribuir para a mantença e não erradicação da doença nos rebanhos, já que não forma anticorpos dificulta o diagnóstico, e o seu posterior descarte. Animais positivos disseminam de forma contínua o vírus pelos fluidos corporais, estes muitas vezes apresentam sinais brandos e inespecíficos sendo o abortamento e malformações fetais muitas vezes os únicos indicadores da presença viral (VIEIRA, 2015).

Sobre a Diarreia Viral Bovina o oeste do estado do Paraná obteve um resultado inexpressivo, onde 696 animais foram testados e somente 29 (4,19\%) amostras de soro avaliadas pela RT-PCRO deram positivo (DEZEN et al., 2013). Foi relatado que $89,65 \%$ das amostras positivas eram provenientes de vacas em produção e 10,35\% de bezerras ou novilhas.

Em um estudo feito por Antoniassi et al. (2013) avaliou-se os fetos, placentas e fragmentos providos de abortamento em bovinos enviados ao setor de patologia da Universidade Federal do Rio Grande do Sul, das 490 amostras apenas 227 (46,32\%) foi possível obter o diagnóstico conclusivo. Das causas de abortamento identificadas, apenas $1(0,44 \%)$ único caso foi atribuído ao BVD, este ainda estava associado ao protozoário Neospora canis. Este resultado é intrigante, pois indica a baixa taxa de abortamento causada pelo BVD nos rebanhos, no entanto, devemos ter em mente que esta pode levar a repetição de cio, perdas embrionárias e fetais, baixo índice de concepção, defeitos congênitos (VIEIRA, 2015) sendo de grande relevância na reprodução e na atividade bovina.

A ocorrência dessa enfermidade varia muito de região para região, o trabalho de Sousa et al. (2013) encontrou 100\% de rebanhos bovinos foco na ilha de São Luiz-MA, com 67,3\% (105/156) dos animais estudados reagentes para BVD. Já em Goiás, a soroprevalêcia encontrada foi de 64\% das fêmeas acima de 24 meses, e 88,3\% (784/888) das 888 propriedades testadas possuíam animais reativos (BRITO et al., 2010). 
Quincozes et al. (2007) no Rio Grande do Sul, descobriram que 82\% (70/85) das 85 propriedades possuíam bovinos reagentes, testando no total 1734 amostras sendo 1150 (66,32\%) positivas, sendo concordante com Brito et al. (2010). No mesmo estado Piovesan et al. (2013) encontraram resultados mais elevados, com $85,4 \%$ dos animais sorologicamente positivos para BVD. Este comparativo mostra uma evolução na taxa de prevalência do vírus no Rio Grande do Sul, no entanto mais pesquisas com estas devem ser desenvolvidas para realmente se afirmar estes, uma vez que ambos os trabalhos coletaram amostras de rebanhos não vacinados e vacinados. O teste de soroneutralização não é capaz de diferenciar se os anticorpos foram gerados pela vacina ou pelo vírus (PIOVESAN et al., 2013). Para causar ainda mais curiosidade, os dados da triagem feita por Possebon et al. (2015) na região nordeste do Rio grande do Sul não foram concordantes com os autores citados, já que das 75 amostras coletadas somente $29,3 \%(22 / 75)$ foram positivas à detecção de anticorpos.

A infecção antes ou pós inseminação artificial ou cobertura pode resultar em problemas reprodutivos, ocorre repetição de cio, perdas embrionárias e fetais, baixo índice de concepção, defeitos congênitos (hipoplasia cerebelar, microftalmia, ulcerações no trato alimentar, braquignatismo, hidrocefalia, porencefalia, artrogripose e desmielinização da medula espinhal entre outros), abortamento, nascimento de bezerros fracos, natimortos e ainda fetos mumificados (POTGIETER, 2004; VIEIRA, 2015). O abortamento ocorre geralmente até o quarto mês de prenhez, infecção após esse período raramente levam ao abortamento, favorecendo o nascimento de bezerros fracos, no entanto, o abortamento pode ser atribuído ao BVDV em qualquer fase de gestação (FLORES, 2007; RIDPATH et al., 2012; PIOVESAN et al., 2013).

O diagnóstico pode ser feito através do isolamento do viral (cultura), detecção de antígenos (ELISA), ou RNA viral (PCR) (JUFFO, 2010). A técnica de imunoistoquímica é considerada de eleição para triagem de animais $\mathrm{PI}$, detectando os antígenos nos fragmentos de orelha coletados para análise, pode ser usada também em casos de abortamentos (tecidos de fetos abortados, placentomas, e fragmentos coletados na necropsia).

O tratamento não é indicado sendo o descarte uma medida de controle. A vacinação é implementada em locais endêmicos como forma de prevenção, e em países que não usam a vacina como medida de controle, as propriedades livres fazem o 
monitoramento sorológico e impedem a entrada de animais infectados, e em rebanhos com presença do vírus, busca-se a eliminação dos animais persistentemente infectados e reagentes, (LINDBERG, 2003; GROOMS et al., 2007). No Brasil a vacina é usada, buscando proteger os animais da doença clínica, impedir a infecção fetal e a consequente produção de animais PI (QUINCOZES et al., 2007; TERRA, 2017). A eficácia da vacina é contestada, uma vez que a imunidade com cepas norte americanas e europeias não garante reação cruzada sorológica em amostras de campo brasileiras (FLORES et al., 2005).

\subsubsection{Fungos e micóticos}

As enfermidades micóticas estão amplamente distribuídas e geram perdas econômicas significativas, podendo ocasionar placentite necrosante e abortamento em várias espécies (JUFFO, 2010; ANTONIASSI et al., 2013). O Aspergillus fumigatus é a espécie mais relacionada aos abortamentos micóticos 60-75\% dos casos (ANTONIASSI et al., 2013).

Não existem muitos trabalhos recentes que relatam a ocorrência de infecções fúngicas que levaram ao abortamento. As pesquisas relacionadas aos fungos em bovinos são mais direcionadas a presença nos alimentos, como no caso a silagem, feno e grãos, pois, estes são os meios propícios ao seu desenvolvimento e relacionado a futuros casos de toxinfecções. Em uma análise realizada no estado de São Paulo, foram coletadas 120 amostragens de silagens de milho, de 30 silos diferentes. A pesquisa se estendeu de janeiro 2009/2010/2011 a outubro 2009/2010/2011. Foram avaliadas silagens de milho e de sorgo pré e pós-fermentadas (após 30 dias de compactação). Verificou-se a presença de Aspergillus sp. em $48 \%$ das amostragens de silo de milho e $59 \%$ nas amostragens de silo de sorgo (KELLER, 2013).

Resultados obtidos no Rio Grande do Sul, acentuam a importância do fungo como causa de abortamento. Dos 147 fetos bovinos abortados, 5 foram conclusivos para Aspergillus sp. Sendo 4 destes atribuídos ao Aspergilus fumigatus e 1 caso ao Aspergillus niger. Totalizando uma prevalência de 3,4\% (5/147) das causas de abortamento diagnosticadas (CORBELLINI et al., 2003).

Antoniassi et al. (2013) também conduziram um estudo parecido, objetivando isolar e diagnosticar a causa etiológica dos abortamentos, através das amostras enviadas 
ao setor de patologia da Universidade Federal do Rio Grande do Sul. Dos 490 fetos abortados, em apenas 227 (46,32\%) foi possível identificar a causa, destes 2,64\% (6/227) foram causados por agentes fúngicos. Este trabalho também afirma o A. fumigatus como o mais importante fungo causador de abortamento em bovinos. Grande parte das amostras foram provenientes do estado do Rio Grande do Sul, no entanto, amostras de Goiás, Minas Gerais, Paraná, Mato Grosso do Sul, São Paulo, Rio de Janeiro, Alagoas, Mato Grosso e Santa Catarina fizeram parte da pesquisa.

A infecção dos animais ocorre em grande parte pela ingestão de grãos ou silagem mofada (NEILAN et al. 1982; CORBELLIN et al., 2003). Os patógenos também podem entrar pelo sistema respiratório, migrar para a circulação sistêmica e levar a uma placentite, causando abortamento (GIVENS; MARLEY, 2008). Acreditasse que esta enfermidade esteja intimamente relacionada a fatores imunodepressores (KNUDTSON; KIRKBRIDE, 1992).

No Brasil já foram descritos casos de broncopneumonias em bovinos por Aspergillus sp. (SANTOS; FARIAS, 1959). A retenção de placenta e placentite são frequentes em casos de abortamentos fúngicos em bovinos (GIVENS; MARLEY, 2008). abortamentos fúngicos acontecem em grande parte entre o sexto e o oitavo mês de gestação (GIVENS; MARLEY, 2008).

O diagnóstico deve ser baseado no exame macroscópico, histopatológico e de cultivo, do conteúdo abomasal e placenta. A coloração de Grocott pode ser usada para revelar a presença de hifas em tecidos hepáticos e pulmonares do feto, e placenta (CORBELLINI et al., 2003). Hillman (1969), destaca que a placenta é o principal tecido afetado, ou seja, o principal meio de diagnóstico conclusivo.

\subsection{Causas de abortamento de origem parasitária}

\subsubsection{Neosporose}

A Neosporose bovina causa elevado prejuízo econômico na bovinocultura de leite e corte, sendo de distribuição cosmopolita (GOODSWEN; KENNEDY; ELLIS, 2013; LLANO, 2013), é considerada atualmente a principal enfermidade infecciosa relacionada a problemas reprodutivos (DUBEY; SCHARES, 2006). Neospora caninum é um protozoário que pertence ao filo apicomplexa e a família sarcocystidae (JUFFO, 2010; LLANO, 2013), pode infectar várias espécies de animais, tais como, canídeos domésticos 
e selvagens, equídeos, bovinos (ADREOTTI et al., 2010) e caprinos (VARASCHIN et al., 2012; MESQUITA et al., 2013).

A Neosporose pode ser considerada uma das principais causas infecciosas que levam ao abortamento em bovinos, isso fica claro na pesquisa realizada por Antoniassi et al. (2013) onde das 490 amostras de abortamento enviadas para o setor de patologia da Universidade federal do Rio Grande do Sul, 160 foram atribuídas ao agente infeccioso. O equivalente a $32,6 \%(160 / 490)$ do total de amostras.

Altas taxas de prevalência em bovinos têm sido encontradas, os anticorpos para N. caninum foi presente em $100 \%$ (10/10) das amostras no estado de Mato Grosso do Sul, 93,7 \% (30/32) no estado de São Paulo, e 85\% (34/40) (17/20) nos estados de Minas Gerais e Goiás respectivamente (ZANATTO et al., 2019).

Em Goiás, anticorpos para N. caninum foi encontrado em 30,43\% das amostras de soro (283/930) (GARCIA, 2005). Todas as 21 propriedades das microrregiões de Anápolis e Goiânia testadas foram consideradas propriedades foco. O ponto interessante deste trabalho foi a relação da porcentagem de animais positivos de rebanhos leiteiros $(30,41 \%)$, de corte $(29,61 \%)$ e misto $(43,30 \%)$, os resultados obtidos não mostram uma frequência maior nos rebanhos leiteiros, divergindo afirmações de autores como Paré et al. (1998) e Álvarez-Garcia (2003) sobre uma maior incidência nos rebanhos e raças leiteiras (citado por GARCIA, 2005).

No estado de Minas Gerais, 60 fetos foram necropsiados após o histórico de abortamento, destes 19 tinham lesões compatíveis, no entanto, somente 14 fetos tiveram o diagnóstico definitivo comprovado para N. caninum, o que relata uma taxa de 23,33\% de positividade para fetos abortados no Sul de Minas Gerais (ORLANDO et al., 2013).

Complementando, um estudo sorológico de N. caninum foi feito comparando amostras de dois abatedouros com Inspeção Municipal, sendo um localizado na cidade de Viçosa, Alagoas e o outro na cidade de São Joaquim do Monte, Pernambuco. Das 133 amostras pertencentes ao estado de Pernambuco, 23 (17,3\%) testaram positivas e das 173 amostras originárias do matadouro de Alagoas, 16 (9,3\%) foram positivas, uma soropositividade de $12,7 \%$ (39/306). O mesmo estudo também comparou amostragens de sangue fetal, das 30 amostras 27 eram provenientes do Estado de Alagoas, e 3 de 
Pernambuco. Encontrou-se 16,7\% (5/30) de amostras positivas, sendo todas do estado de Alagoas (AMARAL et al., 2012).

A transmissão pode ocorrer de forma horizontal pelo consumo de alimentos e/ou água contaminada, e vertical ou transplacentária, principal forma de manutenção do protozoário nos rebanhos bovinos (Garcia, 2005; DUBEY; SCHARES; ORTEGA-MORA, 2007; HEIN et al., 2012). Sendo assim, é possível encontrar rebanhos persistentemente infectados por várias gerações, mesmo sem a presença do hospedeiro definitivo (MALDONADO RIVERA et al., 2020; SANTOS et al., 2011).

O N. caninum invade as células uterinas onde se multiplica e destrói o tecido fetal e materno, gerando resposta imune que leva ao abortamento ou morte embrionária (BUXTON et al., 2002; ORLANDO et al., 2013), definida como a perda desde a concepção até o 42 dia de gestação e se configura como uma das maiores causas de falhas reprodutivas (DUNNE; DISKIN; SREENAN, 2000). Quando a infecção ocorre em vacas não gestantes pode ocorrer formação de cistos na musculatura que entram em latência. Durante a gestação ocorre a recrutância ou reativação dos cistos contendo bradizoítos (GOODSWEN; KENNEDY; ELLIS, 2013; CARVALHO et al., 2014), levando a quadros de abortamentos, repetição de cio, natimortos e nascimento de bezerros fracos persistentemente infectados (FLORES, 2012; SANTANA et al., 2013) O abortamento entre o quinto e sexto mês de prenhez é a manifestação clínica mais importante da enfermidade. Quando a vaca se infecta no início da gestação a morte fetal é muito provável, já no meio da gestação pode ocorrer morte fetal ou nascimento de bezerro congenitamente infectado com sinais clínicos nervosos (ataxia, reflexos patelares diminuídos e exoftalmia) (MEGID; RIBEIRO; PAES, 2016; MALDONADO RIVERA et al., 2020). No terço final da gestação o feto tende a ter mais chances de sobreviver por ter um sistema imune mais responsivo, no entanto, as chances de nascer infectado é alta (BUXTON et al., 2002; FLORES, 2012).

O diagnóstico conclusivo é baseado nas alterações histopatológicas, associado a identificação do protozoário pelo teste imunoistoquímico. O coração, cérebro, fígado e placenta são os órgãos mais indicados (MELO, 2008). A miocardite multifocal e encefalite são lesões microscópicas indicativas de abortamento por N. caninum, sendo as lesões no cérebro as mais constantemente encontradas (DUBEY, 2003; ALMERIA et al., 2010).). Testes sorológicos podem ser usados para a detecção dos anticorpos nos 
animais adultos, no entanto, um resultado negativo não descarta a presença da doença, pois os anticorpos séricos podem variar conforme a idade e o estado da gestação (DUBEY; SCHARES, 2006; MELO, 2008). Dentre eles, os testes de ensaio imunoenzimático (EIE), imunofluorescência indireta (IFI) e aglutinação direta (NAT) (MELO, 2008).

Não existe nenhum tratamento efetivo para Neosporose bovina atualmente (CECHIN; DIAZ, 2013). O controle da doença nos rebanhos se baseia na eliminação dos animais positivos, na introdução de animais livres, e destinação correta dos produtos de abortamentos, evitar o contato entre cães e os rebanhos bovinos (HEIN et al., 2012).

\subsubsection{Tricomonose}

A Tricomonose é uma doença infectocontagiosa de distribuição mundial que acomete bovinos de várias idades, é transmitida de forma venérea, e causada por um protozoário flagelado Tritrichomonas foetus (T. foetus) (ALVES et al., 2011; GOMES, 2015). Este protozoário possui característica móvel e anaeróbio, e se multiplica por divisão binária. Não consegue sobreviver no ambiente por muito tempo, sendo sensível ao calor, e aos desinfetantes comuns (SPOSITO FILHA; OLIVEIRA, 2009).

A Tricomonose por sua vez, foi uma das doenças mais importantes no passado, e após um período de esquecimento, o momento é de incerteza e pouca informação da prevalência nos rebanhos, o entendimento real sobre sua importância e prejuízos devem ser estudados. Paz Júnior et al. (2010) não encontraram a enfermidade no município de Sanharó - PE, neste estudo foi analisado um total de 157 amostras, sendo 150 amostras de fêmeas e apenas 7 de touros. No Distrito Federal também foi obtido resultados semelhantes, o Tritrichomonas foetus não foi isolado em nenhuma das 385 amostras obtidas (LEAL et al., 2012). Neste último trabalho pode-se alegar que o tempo de transporte das amostras e o não repouso sexual prévio possa ter influenciado, outra analogia foi a não realização dos três testes consecutivos, com intervalos de 7 a 15 dias de repouso sexual, o que poderia aumentar a sensibilidade do diagnóstico (LEAL et al., 2012). Ambos os resultados são condizentes com os de Botelho (2014) em Minas Gerais.

Já Botelho e colaboradores (2018) fizeram uma pesquisa no Sul do estado de Minas Gerais, 200 amostras de esmegma de touros ativos foram coletadas nos matadouros de Campo Belo (116 amostras), Boa Esperança (64 amostras) e Perdões (20 
amostras). O estudo revelou positividade de $8 \%(16 / 200)$ para T.foetus, e destas, quatro foram positivas também para C. fetus subsp. venerealis, mostrando que é possível acontecer infeç̧ões mistas, tornando os efeitos reprodutivos mais acentuados nos rebanhos.

Em Pernambuco o teste de PCR foi usado para identificar amostras positivas ao T. Foetus, uma prevalência de 33,4\% (128/383) foi diagnosticada. Dos 21 rebanhos estudados $90,5 \%$ (19/21) foram considerados foco, com pelo menos um animal positivo (OLIVEIRA et al., 2015). Uma maneira de explicar as variações entre os estudos citados, são as diferenças entre os métodos de diagnóstico utilizados e os fatores como distância e transporte das amostras. Segundo Leal et al. (2012) e Oliveira et al. (2015) a adoção de técnicas mais sensíveis como o PCR, diminui essas variações por identificar diretamente $o$ agente.

A transmissão se dá pelo contato genital entre o touro infectado e a vaca, ou vice-versa, ao qual ocorre infecção em quase $100 \%$ dos casos (ALVES et al., 2011). Além da cópula, acreditasse que o protozoário possa ser veiculado por meio de instrumentos obstétricos, cama de feno e vagina artificial contaminada (SPOSITO FILHA; OLIVEIRA, 2009), ou ainda por meio da inseminação artificial com utilização de equipamentos ou sêmen contaminados (RIET-CORREA et al., 2007). Os autores Paz Júnior et al. (2010), destacam que os touros são portadores assintomáticos e importantes disseminadores da doença nos rebanhos.

Os principais sinais clínicos nas fêmeas são foliculite e vestibulite, devido a uma maior predileção do protozoário pela vagina e o vestíbulo (GOMES, 2015). Outros sinais também podem ser observados, como a endometrite, piometra, vaginite, cervicite, alterações do estro, esterilidade temporária, morte embrionária, feto macerado e abortamento precoce (SPOSITO FILHA; OLIVEIRA, 2009). Em rebanhos positivos observase frequente morte do embrião e alterações no ciclo estral, e casos em que a gestação continua a termo, o abortamento acontece entre o terceiro e quinto mês de gestação, associado a persistência de corpo lúteo, feto macerado e piometra (RIET-CORREA et al., 2007).

O diagnóstico é baseado no histórico com problemas reprodutivos e no isolamento do agente. Para isolamento do T. foetus pode ser coletado amostras pelo lavado prepucial ou mucovaginal, sêmen e conteúdo estomacal de feto abortado, e pelo 
swab prepucial (SPOSITO FILHA; OLIVEIRA, 2009). Segundo Pellegrin (2003), o período ideal para a coleta do lavado mucovaginal, são de 2 a 3 dias antes ou 2 a 3 dias depois do cio, pois o agente está em multiplicação durante esse período na mucosa vaginal.

Nas fêmeas a infecção é temporária, tendo duração de três a seis ciclos estrais, não necessitando de medidas terapêuticas, apenas descanso sexual durante esse período (ALVES et al., 2011). No entanto, segundo Rae; Crews (2006) essa prática não é o suficiente, pois, algumas vacas podem manter a infecção por vários meses. Os tratamentos medicamentosos não asseguram a cura, e por ser oneroso é usado apenas para touros com valor zootécnico (PELLEGRIN, 2003), no entanto, o abate deve ser indicado (MARCHIORETTO, 2017).

O controle da Tricomonose Bovina é baseado na implementação da inseminação artificial que substitui a monta natural, principal forma de contágio (GOMES, 2015). A alta prevalência dessa enfermidade está intimamente ligado a regiões onde a monta natural é o principal método reprodutivo (BONDURANT, 2005). Recomenda-se descarte dos touros acima dos sete anos e reposição por touros jovens, de preferência virgens ou com pelo menos três exames negativos consecutivos (SPOSITO FILHA; OLIVEIRA, 2009; GOMES, 2015). A vacina pode ser uma alternativa preventiva nas propriedades, no entanto, a imunidade conferida não dura por muito tempo, apresentando resultados insatisfatórios (SPOSITO FILHA; OLIVEIRA, 2009).

\section{CONSIDERAÇÕES FINAIS}

Esta pesquisa se torna uma fonte valiosa para o aluno de medicina veterinária, Médico Veterinário, produtor, consumidor e público geral, para sanar dúvidas, relacionar informações novas e atualizadas, e perceber a relevância de diagnosticar a causa do abortamento para se tomar medidas de prevenção eficientes e direcionadas, revelar a enfermidade mais diagnosticada nos rebanhos brasileiros, para reafirmar sua importância econômica e relacionar informações entre regiões, comparando os dados entre os anos anteriores e os mais atuais, possibilitando afirmar e/ou contestar a eficiência de medidas preventivas.

Deve-se ter em mente que a vacinação é uma medida de controle muito importante, mas que sozinha não consegue ser totalmente eficiente, sendo necessário 
mais estudos como estes, para verificar a eficácia das medidas tomadas e se há ou não necessidade desta prática na propriedade, região e ou estado.

São vários os desafios dos profissionais a campo, como, animais falso negativos, persistentemente infectados, abortamentos esporádicos e o não diagnóstico etiológico. Saber a causa do abortamento é imprescindível e a complexidade está justamente no diagnóstico, que é definitivo em somete $30-40 \%$ dos casos, muito por conta de a autólise fetal começar ainda no útero, e por existir múltiplas causas que levam ao abortamento, dificultando assim o diagnóstico.

É verdade que este estudo serve como análise da situação epidemiológica no Brasil e a efetividade das medidas de controle impostas. No entanto, existe a necessidade de levantamentos constantes para mensuração das enfermidades mais presentes em cada região, e ainda ampliação dos estudos para definir de fato a capacidade de cada enfermidade infecciosa e parasitária de causar o abortamento nos bovinos.

Por fim, fica exposto a necessidade de conhecer a fundo as principais enfermidades reprodutivas, os métodos de controle e os pontos chaves de cada doença, sabendo que os impactos e perdas econômicas gerados estão muito além da perda fetal.

\section{REFERÊNCIAS}

ABIEC-Associação Brasileira das Indústrias Exportadoras de Carnes. Beef Report: o perfil da pecuária no Brasil. 2019. Disponível em $<$ http://abiec.com.br/publicacoes/beef-report-2019/>. acesso em 28 de agosto de 2020.

ACKERMANN, M.; ENGELS, M. Pro and contra IBR-eradication. Veterinary Microbiology, Amsterdam, v. 113, n. 3-4, p. 293-302, 2006.

ADLER, B.; MOCTEZUMA, A. P. Leptospira and leptospirosis. Veterinary Microbiology, v.140, p.287-296, 2010.

ADREOTTI, R. et al. Association between seropositivy for Neospora caninum and reproductive performance of beef heifers in the Pantanal of Mato Grosso do Sul, Brazil. Revista Brasileira de Parasitologia Veterinária. v. 19, p. 119-123, 2010.

ALMERIA, S. et al. Fetal death in cows experimentally infected with Neospora caninum at 110 days of gestation. Veterinary Parasitology, 169(3-4), p. 304-311, 2010. DOI: https://doi.org/10.1016/j.vetpar.2009.12.044 
ÁLVAREZ-GARCIA, G. Identificación y caracterización de antígenos de neospora caninum con interés inmunodiagnóstico en bovinos. 2003. $301 \mathrm{f}$. Tese (Doutorado em Veterinária) - Facultad de Veterinaria, Universidad Complutense de Madrid, Espanha.

ALVES, T. M. et al. Campilobacteriose genital bovina e tricomonose genital bovina: epidemiologia diagnóstico e controle. Pesquisa Veterinária Brasileira, Belo Horizonte, Minas Gerais, v. 31, n. 4, p. 336-344, 2011.

AMARAL, R. L. G. Neospora caninum em bovinos em matadouros de Pernambuco e Alagoas. Pesquisa Veterinária Brasileira, Recife, Pernambuco, v. 32(10), p. 963966, 2012.

ANTONIASSI, B. A. N. et al. Diagnóstico das causas infecciosas de aborto em bovinos. Biológico. São Paulo, v.69, n.2, p.69-72, 2007.

ANTONIASSI, N. A. B. et al. Causas de aborto bovino diagnosticadas no setor de Patologia Veterinária da UFRGS de 2003 a 2011. Pesquisa Veterinária Brasileira, Porto Alegre, Rio Grande do sul, 33(2): p. 155-160, fevereiro, 2013.

BANDEIRA, K.K; BRUCELOSE BOVINA. 2011. 23 f. Monografia (Especialização) - Curso de Especialização em Produção de Leite, Universidade Tuiuti do Paraná Faculdade de Ciências Biológicas e de Saúde, Cascavel, Paraná.

BARBOSA, A. A. Uso da vacina cepa rugosa contra brucelose em fêmeas bovinas em diferentes estágios da gestação. 2014. 62 f. Dissertação (Mestrado em Reprodução, Sanidade e Bem Estar Animal) - Universidade José do Rosário Vellano, Alfenas, Minas Gerais.

BARBOSA, A. C. V. C. et al. Soroprevalência e fatores de risco para a infecção pelo herpesvírus bovino tipo 1 (BHV-1) no Estado de Goiás, Brasil. Ciência Rural, Santa Maria, v. 35, n. 6, p. 1368-1373, 2005.

BASTOS, C. R. et al. A leptospirose bovina: ocorrência e sorovares predominantes em amostras provenientes de seis estados brasileiros. Ciência \& Tecnologia FatecJB, v. 8, n. esp., 2016.

BEZERRA, D. C. et al. Fatores de risco associados à infecção pelo herpesvírus bovino tipo 1 em rebanhos bovinos leiteiros da região amazônica maranhense. Arquivos do Instituto Biológico, São Paulo, v.79, n.1, p.107-111, 2012.

BONDURANT, R. H. Venereal diseases of cattle: Natural history, diagnosis, and the role of vaccines in their control. Veterinary Clinics of North America: Food Animal Practice, 21:383-408, 2005. 
BOTELHO, M. P. A. Detecção de Tritrichomonas foetus e Campylobacter fetus ssp. veneralis em touros por meio da PCR e PCR multiplex. 2014. 72 f. Dissertação (Mestrado) - Universidade Federal de Lavras, Minas Gerais.

BOTELHO, M. P. A. et al. Prevalence of Tritrichomonas foetus and Campylobacter fetus subsp. venerealis among bulls slaughtered in the state of Minas Gerais, Brazil. Semina: Ciências Agrárias, Londrina, v. 39, n. 5, p. 2039-2048, 2018. DOI: 10.5433/1679-0359.2018v39n5p2039

BRASIL. Doenças infecciosas e parasitárias: guia de bolso. 8. ed. 448p. Ministério da Saúde. Secretaria de Vigilância em Saúde. Departamento de Vigilância Epidemiológica. Revista Brasília, Brasília, Distrito Federal, 2010.

BRASIL. Manual Técnico do Programa Nacional de Controle e Erradicação da Brucelose e Tuberculose Animal (PNCEBT). Ministério da Agricultura, Pecuária e Abastecimento (MAPA). Secretaria de Defesa Agropecuária, Departamento de Defesa Animal. Brasília, 2006.

BRITO, W. M. E. D. et al. Prevalência da infecção pelo vírus da diarréia viral bovina (BVDV) no esta do de Goiás, Brasil. Revista de Patologia Tropical. Vol. 39 (1): 718, 2010.

BUXTON, D. et al. The comparative pathogenesis of neosporosis. Scienc Direct: Trends in Parasitology, v. 18, p. 546-552, 2002.

CANÁRIO, R. et al. Diarreia Viral Bovina: uma afecção multifacetada. Veterinaria.com.pt, Vol. 1 n. 2: e6. 2009.

CARDOSO, S. C. T.; COSTA, L. M. C. A brucelose no Brasil sob o enfoque da saúde pública. Pós-Graduação em Vigilância Sanitária, Universidade Católica de Goiás, Goiás, 2011.

CARVALHO, R. P. et al. Neosporose bovina-revisão de literatura. Revista Científica de Medicina Veterinária, 23(7), p. 1-23, 2014.

CECHIN, D.; DIAZ, J. D. S.; Neosporose bovina: relato de caso. XV Seminário Internacional de Educação no Mercosul, Unicruz, 2013.

CHATE, S. C. et al. Situação epidemiológica da brucelose bovina no Estado do Mato Grosso do Sul. Arquivo Brasileiro de Medicina Veterinária e Zootecnia, Belo Horizonte, v. 61, suplemento 1, p. 46-55, 2009.

CHIAPPARRONE, M. L. et al. Quantitative anlysis of Campylobacter fetus veneralis adhesion to bovine reproductive tract cell cultures. Brazilian Journal of Veterinary Research and Animal Science, v. 48, n. 1, p. 73-78, 2011. 
CORBELLINI, L. G. et al. Aborto por Aspergillus fumigatus e A. niger em bovinos no sul do Brasil. Pesquisa Veterinária Brasileira, v. 23(2), p. 82-86, 2003.

COSTA, E. P. et al. BoHV-1 (o vírus da IBR) e sua relação com estruturas e órgãos genitais da fêmea bovina. Revista Brasileira de Reprodução Animal, Belo Horizonte, v.41, n.1, p.254-263, 2017.

CRESPO, S.E.I. et al. Caracterização molecular de BoHv-1.1 em touros com balanopostite pustular infecciosa. In: I Congresso de Pesquisa em Saúde Animal e Humana, 2016, Paraná. Anais do I COPESA. Universidade Estadual de Londrina, 2016. p. 117- 120.

DEZEN, S. et al. Perfil da infecção pelo vírus da diarreia viral bovina (BVDV) em um rebanho bovino leiteiro de alta produção e com programa de vacinação contra o BVDV1. Pesquisa Veterinária Brasileira, v. 33(2) p. 141-147, 2013.

DIAS, J. A. et al. Fatores de risco associados à infecção pelo herpesvírus bovino 1 em rebanhos bovinos da região Oeste do Estado do Paraná. Pesquisa Veterinária Brasileira, Rio de Janeiro, v.28, p.161-168, 2008.

DIAS, J. A. et al. Seroprevalence and Risk Factors of Bovine Herpesvirus 1 Infection in Cattle Herds in the State of Paraná, Brazil. Transboundary and Emerging Diseases, v.60, p.39- 47, 2013.

DUBEY, J. P. Review of Neospora caninum and neosporosis animals. The Journal Korean of Parasitology, v. 41, n. 1, p. 1-16, 2003.

DUBEY, J. P.; SCHARES, G. Diagnosis of bovine neosporosis. Veterinary Parasitology, v. 140, p. 1-24, 2006.

DUBEY, J. P.; SCHARES, G.; ORTEGA-MORA, L. M. Epidemiology and control of neosporosis and Neospora caninum. Clinical Microbiology Reviews, 20(2), p. 323-367, 2007.

DUNNE, L. D.; DISKIN, M. G.; SREENAN, J. M. Embryo and foetal loss in beef heifers between day 14 of gestation and full term. Animal Reproduction Science, v. 58, p. 39-44, 2000.

FÁVERO, J. F et al. Bovine leptospirosis: Prevalence, associated risk factors for infection and their cause-effect relation. Microbial Pathogenesis, Amsterdam, v. 107, p.149-154, 2017.

FINO, T.C.M. et al. Infecções por herpesvírus bovino tipo 1 (BoHV-1) e suas implicações na reprodução bovina. Revista Brasileira de Reprodução Animal, Belo Horizonte, v.36, n.2, p.122-127, 2012. 
FLORES, E. F. et al. A infecção pelo vírus da Diarréia Viral Bovina (BVDV) no Brasil histórico, situação atual e perspectivas. Pesquisa Veterinária Brasileira, n. 25, v. 3, p. 123-134, 2005.

FLORES, E. F. Virologia veterinária. Ed. da Universidade Federal de Santa Maria, Santa Maria, 2012.

FLORES, E. F. Virologia Veterinária. Ed. UFMS, Santa Maria, p.435-462, 2007.

FLORES, E. F; CARGNELUTTI, J. F. Diagnóstico laboratorial das infecções víricas, In: Flores E.F. (2Ed.), Santa Maria Editora (Ed), Virologia Veterinária. Editora UFSM, capítulo 11, 2012.

FRANCO, A. C.; ROEHE, P. M. Herpesviridae, In: Flores E.F., Virologia Veterinária. Editora UFSM, Santa Maria, p.433-488, 2007.

FRIAS, R. et al. Pesquisa de agentes causadores da campilobacteriose e trichomonose genital bovina em reprodutores puros de origem do estado de mato grosso do sul. Revista de la Sociedad Venezolana de Microbiología, Caracas, Venezuela, vol. 37, n. 2, p. 50-53, 2017.

FULTON, R. W. et al. Transmission of bovine viral diarrhea virus $1 \mathrm{~b}$ to susceptible and vaccinated calves by exposure to persistently infected calves. Canadian Journal of Veterinary Research, 69: 161-169, 2005.

GARCIA, D. P. Neosporose bovina: prevalência, transmissão e diagnóstico em fetos abortados, nas microrregiões de Anápolis e Goiânia - Goiás. 2005. 41 f. Dissertação (Mestrado) - Escola de Veterinária da Universidade Federal de Goiás, Goiânia.

GENOVEZ, M. E. Leptospirose em Animais de Produção. In: MEGID, J; RIBEIRO, M. G; PAES. A. C. Doenças Infecciosas em Animais de Produção e de Companhia. 1. Ed. Rio de Janeiro: Roca, 2018. p. 378-387.

GIVENS, M. D.; MARLEY, M.S.D. Infectious causes of embryonic and fetal mortality. Scienc direct: Theriogenology, 70, p. 270-285, 2008.

GOMES, M. J. Gênero Leptospira spp. Faculdade de Veterinária, Universidade Federal de Rio Grande do Sul, 2015.

GOODSWEN, S. J.; KENNEDY, P. J.; ELLIS, J. T. A review of the infection, genetics, and evolution of Neospora caninum: from the past to the present. Infection, Genetics and Evolution, 13, 133-150, 2013. DOI: 10.1016/j.meegid.2012.08.012

GROOMS et al. Fetal protection against continual exposure to bovine viral diarrhea virus following administration of a vaccine containing an inactivated bovine viral 
diarrhea virus fraction to cattle. American Journal of Veterinary Research, v. 68, n. 12, p. 1417-1422, 2007.

HAMZÉ, A. L. et al. Rinotraqueíte Bovina. Revista cientifica eletrônica de Medicina Veterinária, $\quad$ n.12, 2011. Disponível em: $<$ https://silo.tips/download/rinotraqueite-bovina>. Acesso em: 30 de agosto de 2020.

HEIN, H. E. et al. Neosporose bovina: avaliação da transmissão vertical e fração atribuível de aborto em uma população de bovinos no Estado do Rio Grande do Sul. Pesquisa Veterinária Brasileira, 32(5), p. 396-400, 2012.

HILLMAN, R. B. Bovine mycotic placentitis in New York State. Cornell Veterinary. V. 59, p. 269-288, 1969.

HIRSH, D. C.; ZEE, Y. C. Microbiologia Veterinária. Rio de Janeiro: Guanabara Koogan, 2009, 446p.

IBGE-Instituto Brasileiro de Geografia e Estatística. Produção da Pecuária Municipal/efetivo rebanho. Rio de Janeiro, 2018. Disponível em <https://cidades.ibge.gov.br/brasil/go/goiania/pesquisa/18/16459?indicador=1 $6533 \&$ tipo=ranking\&ano=2018 $>$. acesso em 28 de agosto de 2020

JAGUSZESKI, M. Z. et al. Tricomonose e Campilobacteriose em bovinos: revisão de literatura. Arquivos de Ciências Veterinárias e Zoologia da UNIPAR, Umuarama, v. 20, n. 1, p. 41-44, 2017.

JONES, C.; CHOWDHURY, S. A review of the biology of bovine herpesvirus type 1 (BoHV$1)$, its role as a cofactor in the bovine respiratory disease complex and development of improved vaccines. Animal Health Research Reviews, v. 8, n. 2, p. 187-205. 2008.

JONES, C.; DA SILVA, L. F.; SINANI, D. Regulation of the latency-reactivation cycle by products encoded by the bovine herpesvirus 1 (BHV-1) latency-related gene. Journal For Neurovirology, v.17, p.535-45, 2011.

JUFFO, G. D. Abortamento em Bovinos principais causas infecciosas. Trabalho de conclusão de curso (Monografia) - Faculdade de Medicina Veterinária, Universidade Federal do Rio Grande do Sul. Porto Alegre, Rio Grande do Sul, 2010.

JÚNIOR, A. A. J. BRUCELOSE EM BOVINOS NO ESTADO DA PARAÍBA (2006 - 2015). 2017. 49 f. Trabalho de Conclusão de Curso (Monografia) - Curso de Graduação em Zootecnia, Universidade Federal da Paraíba. Areia, Paraíba.

KELLER, L. A. M. Contaminação fúngica toxígena e qualidade micotoxicológica de silagens destinadas a alimentação de bovinos no Estado de São Paulo. 2013. 180 
f. Tese (doutorado) - Universidade Federal Rural do Rio de Janeiro, Curso de PósGraduação em Ciências Veterinárias, Seropédica, Rio de Janeiro.

KNUDTSON, W. U.; KIRKBRIDE, C. A. Fungi associated with bovine abortion in the northern plains states (USA). Journal of Veterinary Diagnostic Investigation, 4:181-5, 1992.

LAGE, A. P. et al. Brucelose bovina: uma atualização. Revista Brasileira de Reprodução Animal. Belo Horizonte, Minas Gerais, v.32, n.3, p.202-212, 2008.

LAWINSKY, M. L. J. et al. Estado da arte da brucelose em Humanos. Revista PanAmazônia de saúde, Brasília, Distrito Federal, 4 ed., p. 75-84, 2010.

LEAL FILHO, J. M. et al. Control of bovine brucellosis from 1998 to 2009 in the state of Mato Grosso do Sul, Brazil. Semina: Ciências Agrárias, v. 37, Supl. 2, p. 3467-3478, 2016.

LEAL, D. R et al. Prevalência da campilobacteriose e da tricomonose genitais bovinas no Distrito Federal e em seu entorno. Universidade de Brasília, Faculdade de Agronomia e Medicina Veterinária, Brasília, DF, Brasil. Revista Brasileira de Reprodução Animal, Belo Horizonte, v.36, n.4, p.256-259, 2012.

LEVETT, P. N. Leptospirosis: A forgotten zoonosis? Clinical Applied Immunology Reviews, p. 435-448, 2004.

LI, Z. J. et al. Molecular Typing of Brucella Suis Collected from 1960s to 2010s in China by MLVA and PFGE. Biomedical and Environmental Sciences. China, v.26, n. 6, p. 504-8, 2013.

LICURGO, J. B. Prevalência e Fatores de Risco da Brucelose Bovina no Distrito Federal, Brasil, 2015. 2016. 54 f. Dissertação (Mestrado em Saúde Animal) - Universidade de Brasília, Brasília, Distrito Federal.

LINDBERG, A. L. E. Bovine viral Diarrhoea virus infections and its control. A review. Veterinary Quarterly, v. 25, n. 1, p. 1-16, 2003.

LLANO, H. A. B. Revisão e situação atual da brucelose e leptospirose em bovinos no Brasil e na Colômbia. 2013. 50 f. Seminário Apresentado Junto à Disciplina Seminários Aplicados. Programa de Pós Graduação Em Ciência Animal (Mestrado) - Escola de Veterinária e Zootecnia Da Universidade Federal de Goiás. Goiânia.

LOMAR, A.V. et al. Leptospiroses. In: FOCACCIA, R. Tratado de Infectologia. 3.ed. São Paulo: Atheneu, 2005. p. 1239-1256.

LOPES, J. Gemelaridade em vacas leiteiras: incidência e a sua influência no desempenho produtivo em explorações do Litoral Norte de Portugal. 2013. 13- 28 f. 
Dissertação (Mestrado em Medicina Veterinária) - Universidade de Trás-osMontes e Alto Douro, Vila Real.

LPS, List of prokayortic name with standing in nomenclature. Naming of Brucella Species. Disponível em < http://www.bacterio.net/brucella.html>. Acesso em agosto de 2020.

MACHADO, F. M. E; COELHO, H. E; REZENDE, R. S. Plano de ação para o controle da leptospirose no zoológico municipal de Uberaba-MG. Bioscience Journal, Uberlândia, v. 26, n. 6, p. 981-989, 2010.

MALDONADO RIVERA, J. E. et al. Bovine neosporosis in dairy cattle from the southern highlands of Ecuador. Veterinary Parasitology: Regional Studies and Reports, 20(1), p. 1-15, 2020. DOI:https://doi.org/10.1016/j.vprsr.2020.100377

MAPA. Manual Técnico do Programa Nacional de Controle e Erradicação da Brucelose e Tuberculose Animal (PNCEBT). Instrução Normativa SDA no 10, de 3/03/2017.

MARCHIORETTO, V. P. Principais doenças infecciosas que acarretam em perdas reprodutivas em bovinos de corte: uma revisão. 62 f. 2017. Monografia (Graduação em Medicina Veterinária). Universidade Federal do Rio Grande do Sul, Porto Alegre, Rio Grande do Sul.

MASCARENHAS, R. et al. Causas de abortos em animais de produção. Revista interdisciplinar de ensino, pesquisa e extensão. Cruz alta, Rio Grande do Sul, v. 7, p. 11 - 20, 2019.

MEGID, J.; RIBEIRO, M. G.; PAES, A. C. Doenças infecciosas em animais de produção e de companhia. Roca, 2016.

MELO, D. P. G. Isolamento de Neospora Caninum de bovinos e caracterização biológica de isolados em Camundongos Balb/C. 2008. 71 f. Tese (Doutorado em Ciências Agrárias) - Universidade Federal de Goiás, Goiânia, 2008.

MESQUITA, L. P. et al. Antibody kinetics in goats and conceptuses naturally infected with Neospora caninum. Journal Veterinary Parasitology, v. 196, p. 327-332, 2013.

MIASHIRO, A. F. et al. Prevalência de leptospirose em rebanhos bovinos no Pantanal de Mato Grosso do Sul. Pesquisa Veterinária Brasileira, 38(1):41-47, janeiro 2018.

Ministério da Agricultura, Pecuária e Abastecimento, Diário Oficial da União. Brasília, Distrito Federal, 2017.

MONTES, T. M. Estudo epidemiológico da brucelose em fêmeas bovinas adultas na regional Rio das Antas, Goiás. 2017. 71 f. Dissertação (Mestrado em Ciência Animal) - Escola de Veterinária e Zootecnia, Universidade Federal de Goiás. Goiânia. 
MOREIRA, S. P. G. et al. Monitoração de anticorpos neutralizantes para o vírus da rinotraqueíte infecciosa bovina em bezerros. Brazilian Journal of Veterinary Research and Animal Science, São Paulo, v. 38, n. 3, p. 127-130, 2001.

MUYLKENS, B. et al. Bovine herpesvirus 1 infection and infectious bovine rhinotracheitis. Veterinary Researc, v.38, p.181-209, 2007.

NASCIMENTO, E. F.; SANTOS, R. L. Patologia da reprodução dos animais domésticos. 3 ed. Rio de Janeiro: Guanabara Koogan, 2011, 153p

NEILAN, M. C. et al. Mycotic pneumonia, placentitis and neonatal encephalitis in dairy cattle caused by Mortierella wolfii. Australian Veterinary Journal, 59:48-49, 1982.

NEWCOMER, B. W. et al. Prevention of abortion in cattle following vaccination against bovine herpesvirus 1: A meta-analysis. Preventive Veterinary Medicine, v.138, p.1-8, 2017.

OIE. World Organization For Animal Health. Manual of Diagnostic Tests and Vaccines for Terrestrial Animals, 2009.

OLIVEIRA, J. M. B et al. Prevalence and risk factors associated with bovine genital campylobacteriosis and bovine trichomonosis in the state of Pernambuco, Brazil. Tropical Animal Health and Production, v. 47, n 3 47, p. 549-555, 2015. DOI 10.1007/s11250-015-0761-3

OLIVEIRA, M. T. et al. Detection of bovine herpesvirus 1 and 5 in semen from Brazilian bulls. ScienceDirect: Theriogenology, Stoneham, v.75, n. 6, p. 1139-1145, 2011.

OLIVEIRA, R. L. et al. Nutrição e manejo de bovinos de corte na fase de cria. Revista Brasileira de Saúde e Produção Animal, v.7, p.57-86, 2006.

ORLANDO, D. R. et al. Abortos por Neospora caninum em bovinos do sul de Minas Gerais. Pesquisa Veterinária Brasileira, Lavras, Minas Gerais, 33(11): p. 13321338, 2013.

PAES, A. C. Leptospirose Canina. In: MEGID, J; RIBEIRO, M. G; PAES. A. C. Doenças Infecciosas em Animais de Produção e de Companhia. 1. Ed. Rio de Janeiro: Roca, 2018. p. 356-377.

PARÉ, J. et al. Seroepidemiologic study of Neospora caninum in dairy herds. Journal of American Veterinary Medical Association, v. 213, p. 1595-1598, 1998.

PASQUALOTTO, W.; SEHNEM, S.; WINCK, C. A. incidência de Rinotraqueíte Infecciosa Bovina (IBR), Diarreia Viral Bovina (BVD) e leptospirose em bovinos leiteiros da região oeste de Santa Catarina - Brasil. Revista em Agronegócio e Meio 
Ambiente, Maringá, Paraná, v.8, n.2, p. 249-270, 2015. DOI:http://dx.doi.org/10.17765/2176-9168.2015v8n2p249-270

PATEL, J. R. Characteristics of live bovine herpesvirus-1 vaccines. Veterinary Journal, London, v. 169, n. 3, p.404-416, 2005.

PAULA, E.M.N. et al. Principais causas bacterianas de abortamento em bovinos. Publicações em Medicina Veterinária e Zootecnia. Londrina, Paraná, V. 8, N. 7, Ed. 256, Art. 1699, abril, 2014.

PAULIN, L. M. S.; FERREIRA NETO, J. S. Brucelose em búfalos. Arquivos do Instituto Biológico. São Paulo, v.75, n.3, p.389-401, 2008.

PAULIN, L.M.S.; FERREIRA NETO, J. S. O combate à brucelose bovina: Situação brasileira. Fundação de Apoio a Pesquisa, Ensino e Extensão. Jaboticabal, São Paulo, p. 154. 2003.

PAZ JÚNIOR, C. J. et al. Frequência de infecção por Tritrichomonas foetus (RIED MULLER, 1928) em bovinos leiteiros do município de Sanharó - Pernambuco, Medicina Veterinária, v. 4, n.1, p. 6-11, 2010.

PELLEGRIN, A. O. Campilobacteriose genital bovina na sub-região da Nhecolândia Pantanal Matogrossense e proposição de novas técnicas diagnósticas. 2001. 74 f. Tese (Doutorado em Ciência Animal). Escola de Veterinária, Universidade Federal de Minas Gerais, Belo Horizonte.

PELLEGRIN, A. O. et al. Imunofluorescência direta: um teste sensível e específico para o diagnóstico da campilobacteriose genital em touros. Embrapa Pantanal: Circular Técnica, 44. Corumbá, MS, 2003.

PELLEGRIN, A.O. et al. Bovine Genital Campylobacteriosis in Pantanal, Mato Grosso do Sul State, Brazil. Revue d'élevage et de médecine vétérinaire des pays tropicaux, 55(3)160-173, 2002.

PIOVESAN, M. et al. Anticorpos contra o herpesvírus bovino tipo 1, vírus da diarreia viral bovina e vírus da leucose enzoótica bovina na região da campanha do estado do Rio Grande do Sul. Scienc and Animal Heart, v.1 n. 1, p. 38-49, 2013.

PITUCO, E.M. Aspectos clínicos, prevenção e controle da IBR. Instituto Biológico Secretária de Agricultura e Abastecimento de São Paulo, n. 94, 2009.

POESTER F. P. et al. Estudos de prevalência da brucelose bovina no âmbito do Programa Nacional de Controle e Erradicação de Brucelose e Tuberculose: Introdução. Arquivo Brasileiro de Medicina Veterinária e Zootecnia. Brasília, Distrito Federal, 31 v.61, supl. 1, p.1-5, 2009. 
POSSEBON, K. F.; MRTINS, L. R. V. Soroprevalência da Diarreia Viral Bovina na região noroeste do estado do Rio Grande do Sul. XXII Seminário de Iniciação Científica, Relatório técnico-científico, Santa Rosa, 2014.

POTGIETER, L. N. D. Bovine viral diarrhea and mucosal disease. In: Infectious Diseases of Livestock. 2 ed. Oxford University Press Southern África, Cape Town, v.2. p.946969, 2004.

PROBERT, W.S. et al. Real-time multiplex PCR assay for detection of Brucella spp., B. abortus, and B. melitensis. Washington, v. 42, n. 3, p.1290-1293, 2004. Disponível em: <www.ncbi.nlm.nih.gov/pubmed/15004098>. acesso em 20 de agosto de 2020.

QUINCOZES, C. G. et al. Prevalência e fatores associados à infecção pelo vírus da diarréia viral bovina na região Sul do Rio Grande do Sul. Semina: Ciências Agrárias, Londrina, v. 28, n. 2, p. 269-276, 2007.

QUINN, P. J. et al. Microbiologia veterinária e doenças infecciosas. Porto Alegre: Artmed, 2005, 512p.

QUINTEIRO, R. C. Avaliação molecular da excreção do herpesvírus bovino tipo 1 (BoHV1) no sêmen de touros do Estado de Mato Grosso. 2016. 52 f. Dissertação (Mestrado) - Pós-graduação em Biociência Animal, Universidade de Cuiabá.

RADOSTITS, O. M. et al. Veterinary Medicine: a textbook of the diseases of cattle, sheep, goats, pigs and horses. 10. ed. Saunders, 2006.

RAE, D. O.; CREWS, J. E. Tritrichomonas foetus. Veterinary Clinics Food Animal Practice, v. 22, p. 595-611, 2006.

RIDPATH, J. F. et al. Flaviviridae. In: FLORES, E. F (Org.) Virologia Veterinária. Santa Maria: Ed. da UFSM, 2012.

RIET-CORREA, F. et al. Doenças de ruminantes e equídeos. v.1. 3 ed. São Paulo: Varela, 2007, 722p.

ROCHA, W. V. et al. Situação epidemiológica da brucelose bovina no Estado de Goiás. Arquivo Brasileiro de Medicina Veterinária e Zootecnia, v. 61, supl 1, p. 27-34, 2009.

ROLIM, M. B. Q. et al. Leptospirose em bovinos: revisão. Medicina Veterinária, Recife, Pernambuco, v.6, n.2, p.26-31, 2012.

ROMANI, A. F. Investigação soroepidemiológica e molecular de brucelose e leptospirose em núcleos de conservação de gado curraleiro pé duro e pantaneiro. 2012. Tese (Doutorado em Ciência Animal) - Universidade Federal de Goiás, Escola de Veterinária e Zootecnia, Goiânia. 
RUFINO, F. A.; SENEDA, M. M.; ALFIERI, A. A. Impacto do Herpesvírus Bovino 1 e do vírus da Diarréia Viral Bovina na transferência de embriões. Archives of Veterinary Science, v. 11, n. 1, p. 78-84, 2006.

RUIBAL, M. D. P. V. Avaliação de diferentes protocolos de extração de DNA para detecção de Brucella abortus a partir de diferentes tecidos de vacas infectadas experimentalmente com a cepa 2308. 2009. 79 f. Dissertação (Mestrado em Epidemiologia Experimental e aplicada às Zoonoses) - Faculdade de Medicina Veterinária e Zootecnia, Universidade de São Paulo.

SANTANA, P. V. Investigação da ocorrência de leptospirose e sua relação com dados reprodutivos e produção de leite em um rebanho bovino no município de Sacramento, MG. Trabalho de Conclusão de Curso (Monografia). Faculdade de Medicina Veterinária, Universidade Federal de Uberlândia. Uberlândia, 2019.

SANTANA, R. C. M. et al. Estudo epidemiológico sobre as perdas reprodutivas em bovinos leiteiros: ocorrência de Neospora Caninum, Brucella Abortus, Herpesvírus Bovino Tipo-1 e Leptospira Spp. em uma propriedade do Município de São Carlos-SP. Ars Veterinaria, p. 153-160, 2013.

SANTOS, D. S. et al. Neospora caninum in bovine fetuses of Minas Gerais, Brazil: genetic characteristics of rDNA. Revista Brasileira de Parasitologia Veterinária, 20(4), p. 281-288, 2011. DOI: https://doi.org/10.1590/s1984- 29612011000400005

SANTOS, J. A.; FARIAS, J. F. Aspergilose do aparelho respiratório de bezerros. Arquivos do Instituto Biológico Animal, Rio de Janeiro, v. 2. p. 15-20, 1959.

SANTOS, M. R. et al. Antibodies against Bovine herpesvirus 1 in dairy herds in the state of Espírito Santo, Brasil. Revista Ceres, v. 61, p. 280-283, 2014.

SILVA, V. L. Estudo retrospectivo da ocorrência de falhas reprodutivas em vacas leiteiras. Trabalho de conclusão de curso (Graduação) - Bacharelado em Zootecnia, Instituto Federal Goiano Campus Morrinhos, Morrinhos, Goiás, 2016.

SILVA, V. L. et al. Falhas reprodutivas em vacas leiteiras. Colloquium Agrariae. Morrinhos, Goiás, vol. 13, n. Especial 2, p. 199-212, 2017.

SIMÕES, L. S. Leptospirose - Revisão. Publicações em Medicina Veterinária e Zootecnia. São Paulo, v.10, n.2, p. 138-146, 2016. DOI: 10.22256/pubvet.v10n2.138-146

SOARES, C. P. O. C. et al. Prevalência da Brucella spp em humanos. Revista LatinoAmericana de Enfermagem, Maceió, Alagoas, v. 23, ed. 5, p. 919-26, 2015.

SOLA, M. C. et al. Brucelose bovina: revisão. Enciclopédia Biosfera. Goiânia, v. 10, n. 18; p. 686, 2014. 
SOUSA, E. V. et al. Frequência de anticorpos e fatores de risco associados à infecção pelo vírus da Diarréia Viral Bovina (BVDV) e Herpesvírus Bovino tipo 1 (BOHV-1) em fêmeas bovinas leiteiras criadas em sistema de produção semi-intensivo. Revista Brasileira de Ciência Veterinária, v. 35 n. 1, p. 21-25, 2013.

SOUSA, V. E. et al. Frequência de anticorpos contra Herpesvírus Bovino tipo 1 (BoHV-1) em bovinos não vacinados da Bacia Leiteira de Imperatriz-MA, Brasil. Arquivo Brasileiro de Medicina Veterinária e Zootecnia, Belo Horizonte, v.35, n. 1, p.775778, 2011.

SPOSITO FILHA, E.; OLIVEIRA, S. M. Divulgação técnica: Tricomonose bovina. O Biológico, 71(1), p. 9-11, 2009.

TEIXEIRA, C. C. L. Prevalência de leptospirose em vacas leiteiras no município de João Pinheiro, Minas Gerais. Trabalho de Conclusão de Curso (Monografia) - Centro Universitário do Planalto Central Aparecido dos Santos - Doenças Infecciosas dos Animais Domésticos, Gama, Distrito Federal, 2019.

TERRA, M. L. Perdas Gestacionais na Bovinocultura de Corte do Rio Grande do Sul. Trabalho de conclusão de Curso (Monografia). Faculdade de Medicina Veterinária, Universidade Federal do Rio Grande do Sul. Porto Alegre, Rio Grande do Sul, 2017.

URZÊDA, M. et al. Soroprevalência de herpesvírus bovino tipo 1 em fêmeas bovinas na microrregião do Vale do Rio dos Bois, Goiás, Brasil. Veterinária Notícias, Uberlândia, Minas Gerais, v.24 n.2, p.72-85, 2018. DOI: http://dx.doi.org/10.14393/VTN-v24n2-2018.6-

VARASCHIN, M. S. et al. Congenital Neosporosis in Goats from the State of Minas Gerais, Brazil. The Journal Korean of Parasitology, v. 50, p. 63-67, 2012.

VIEIRA, A. S. Levantamento epidemiológico sobre Diarréia Viral Bovina em bovinos leiteiros no município de Ametista do Sul. 57 f. 2015. Dissertação (Mestrado). Universidade de Cruz Alta, Rio Grande do Sul.

VIEIRA, S. et al. Anticorpos para o herpesvírus bovino 1 (BHV-1) em bovinos do Estado de Goiás. Ciência Animal Brasileira, v. 4, p. 131- 137, 2003.

VIU, M.A.O. et al. Rinotraqueíte infecciosa bovina: revisão. Publicação em Medicina Veterinária e Zootecnia, Londrina, V. 8, N. 4, Ed. 253, Art. 1678, 2014.

WHO, World Health Organization. The Control of Neglected Diseases: A route to poverty alleviation. Disponível em <http://www.who.int/zoonoses/ReportSept06.pdf>. Acessado em agosto de 2020.

ZANATTO, D. C. S. et al. Coxiella burnetii associated with BVDV (Bovine Viral Diarrhea Virus), BoHV (Bovine Herpesvirus), Leptospira spp., Neospora caninum, 
Toxoplasma gondii and Trypanosoma vivax in reproductive disorders in cattle. Brazilian Journal of Veterinary Parasitology, Jaboticabal, v. 28, n. 2, p. 245-257, 2019. Doi: https://doi.org/10.1590/S1984-29612019032

ZIECH, R. E. et al. Campylobacter fetus em bovinos no estado do Rio Grande do Sul. Ciência Rural, v. 44, n. 1, p. 141-146, 2014. 


\section{CAPÍTULO II}

\section{ADENITE EQUINA - IMPACTOS CLÍNICOS E EPIDEMIOLÓGICOS}

DDI: 10.51859/amplla.pdi443.1121-2

Jorge Felipe Gomes Dallabrida ${ }^{1}$

Rodrigo Martins Ribeiro ${ }^{2}$

Priscila Chediek Dall'Acqua ${ }^{2}$

Eric Mateus Nascimento de Paula ${ }^{2}$

${ }^{1}$ Médico Veterinário Autônomo. Egresso do Curso de Medicina Veterinária do Centro Universitário de Mineiros UNIFIMES

${ }^{2}$ Docente do Curso de Medicina Veterinária do Centro Universitário de Mineiros - UNIFIMES.

\section{RESUMO}

No Brasil, a criação de equinos é uma atividade de grande importância econômica, gerando empregos e renda a população, visto que ela está em incessante crescimento. Dentre as enfermidades que agridem os equinos, as afecções do sistema respiratório é o segundo grupo com maior ocorrência, sendo a principal estudo a Adenite. Dessa forma, o objetivo do presente estudo foi realizar um levantamento bibliográfico sobre os principais aspectos da Adenite Equina, através de um levantamento bibliográfico exploratório. Abordando assuntos inerentes a doença, como: o agente etiológico, epidemiologia, etapas da patogênese, bem como as implicâncias sintomatológicas da doença e principais condutas diagnósticas e terapêuticas frente ao garrotilho. A doença possui um elevado índice de morbidade e grande potencial em ocasionar sequelas ao animal. Nota-se a grande relevância dos estudos realizados nessa área, diante a importância da doença frente ao comércio, o qual aumenta cada dia mais e consequentemente agride o animal devido as mudanças em seu estilo de vida.

Palavras-chave: Sistema Respiratório. Garrotilho. Equinos.

\section{INTRODUÇÃO}

No Brasil, a criação de equinos é uma das atividades com animais, que mais geram empregos e renda a população, ela está em incessante crescimento. Dessa forma, o cuidado com esses animais diante, das inúmeras patologias existentes são de extrema importância para o comércio, a fim de evitar possíveis prejuízos (SILVA; VARGAS, 2016). 
$\mathrm{Na}$ infectologia equina, as afecções do sistema respiratório é o segundo grupo de enfermidades com maior ocorrência, e quando pensamos especialmente na adenite equina, esta representa aproximadamente 30\% das notificações de doenças em equídeos em todo o globo (LIBARDONI, 2015).

A adenite equina, ou popularmente conhecida como garrotilho, é uma moléstia infectocontagiosa majoritariamente aguda, definida pela inflamação mucopurulenta do trato respiratório superior dos equídeos (LIBARDONI, 2015). Essa patologia é ocasionada pela bactéria Streptococcus equi, a qual atinge o trato respiratório dos equinos em todas as faixas etárias, entretanto, com maior ocorrência nos mais jovens. Outros fatores que debilitam o sistema imune do animal, juntamente com aglomerações (animais doentes e sadios), condições higiênicas do ambiente e do animal podem potencializar os riscos de infecção (AMARAL et al., 2018).

O garrotilho é uma doença de grande importância econômica na exploração equina brasileira que apresenta, dificuldades em seu diagnóstico laboratorial pela presença de cepas atípicas de S. equi, subsp. equi, assim como em sua prevenção (MORAES et al., 2009).

O diagnóstico e prevenção das doenças infecciosas nessa espécie adquirem, portanto, especial significação. A detecção precoce de problemas respiratórios é essencial para o rápido retorno dos animais a sua atividade, bem como na prevenção de complicações secundárias que podem encerrar prematuramente a carreira do animal. O controle da enfermidade requer a detecção precoce e segura de animais portadores, é necessário padronizar métodos e interpretações. Técnicas baseadas na moderna biologia molecular, tais como PCR, clonagem e expressão de proteínas de interesse devem ser validadas, visando a aprimorar sua eficiência e rapidez (MORAES et al., 2009).

Desta maneira, o objetivo do presente estudo é construir uma revisão bibliográfica geral sobre os principais aspectos relacionados a etiologia, epidemiologia, sintomatologia e prevenção da Adenite Equina. 


\section{REVISÃO DE LITERATURA}

\subsection{Definição}

Adenite equina ou garrotilho é uma enfermidade de caráter infectocontagioso, que tem como principal característica um quadro de linfadenite e infecção do trato respiratório superior de equídeos, causada pela bactéria Streptococcus equi (RIBEIRO; VARGAS, 2016). Robinson et al. (2016) afirma que é a doença infecciosa de equinos mais frequentemente diagnosticada em todo o mundo.

O nome popular da enfermidade advém, historicamente, de equídeos acometidos e não tratados que apresentavam aspecto de garroteamento ou sufocamento, em virtude da dificuldade respiratória provocada pela obstrução da faringe devido ao intumescimento dos linfonodos que drenam a região cervical (RIBEIRO; VARGAS, 2016).

\subsection{Histórico}

Sendo umas das primeiras doenças a serem relatadas em publicações cientificas veterinária (SWEENEY, 1990, p.519). No ano de 1664, SOLLEYSEL, descreveu a adenite como uma doença contagiosa em equinos jovens. Concluiu que, a doença era contagiosa e era indicado o isolamento dos animais acometidos e, que os cochos de água utilizados pelos animais seria uma fonte de infecção. Já no ano de 1790, LAFARSE provou que se tratava de uma doença contagiosa e, VIBORG confirmo em 1802 (SWEENEY et al 1987, p.689).

RIVOLTA em 1873 foi o primeiro a observar cadeias de cocos na secreção purulenta do abscesso de um equino com a doença. Mas em 1888 SCHUTZ quem fez a primeira publicação com a descrição do microrganismo que o Streptococcus equi seria o agente causador da adenite equina SWEENEY et al (1987, p.689).

\subsection{Agente Etiológico}

Estreptococos são bactéria gram positiva que pertencem a família Streptococcaceae, em formato de cocos distribuídos em cadeias, que se estruturam em apenas um plano (Figura 1). Além disso, são anaeróbios facultativos, não se movem e são negativos para o teste da catalase (RIBEIRO; VARGAS, 2016). 
Figura 1 - Exame microscópio de Streptococcus equi corado com coloração de Gram mostrando cocos Gram-positivos disposto em pares

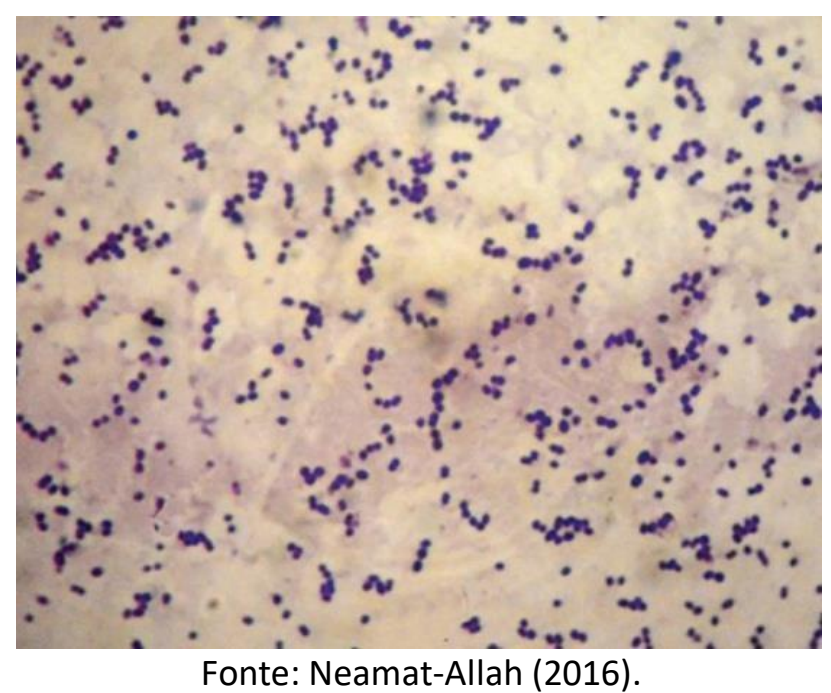

São reconhecidas 37 espécies de estreptococos isoladas tanto em humanos e animais podem ser encontradas no ambiente. Estreptococos. Dentre a classificação dos estreptococos dos grupos de Lancefield, podemos destacar o grupo C que compreendem bactérias de interesse na medicina equina, o que incluem $\mathrm{S}$. equi subesp equi e S. equi subesp. zooepidemicus. Ambas envolvidas na adenite equina e em outras afeç̧ões de equídeos. Além dessas espécies de estreptococos, de forma geral, equídeos também podem ser acometidos pelo $S$. dysgalactiae subesp. equisimilis, suas diferenças bioquímicas estão na tabela 1. De todas, a subespécie equi é a mais patogênica para esses animais (RIBEIRO; VARGAS, 2016).

Tabela 1 - Padrão de hemólise e fermentação de açúcares das espécies de estreptococos do grupo $\mathrm{C}$ de Lancefield

\begin{tabular}{|l|c|c|c|c|}
\hline \multicolumn{1}{|c|}{ Espécie } & Hemólise & Sorbitol & Trealose & Lactose \\
\hline S. equi subesp equi & Beta & Negativo & Negativo & Negativo \\
\hline S. equi subesp. zooepidemicus & Beta & Negativo & Positivo & Negativo \\
\hline S. dysgalactiae subesp. equisimilis & Beta & Positivo & Negativo ou positivo & Positivo \\
\hline
\end{tabular}

Fonte: Adaptado de Fonseca et al. (2010).

De maneira geral, o ciclo de vida do S. equi nos equídeos caracterizam- se por uma enfermidade aguda de pouca duração, que pode persistir por vários meses no interior das bolsas guturais. Essa habilidade aprimora a virulência e disseminação do agente para animais suscetíveis (ROBINSON et al., 2016). 
A adenite propriamente dita é causada pela S. equi subesp. equi. Ocasionalmente, uma sintomatologia semelhante da doença pode ser provocada pelo S. equi subesp. zooepidemicus. Além disso, alguns pesquisadores sugerem que "as condições nesses diferentes ambientes do hospedeiro, provavelmente, influenciaram a perda ou aquisição de genes que moldaram o genoma do S. equi", (HOLDEN et al., 2009).

As subespécies equi e zooepidemicus são extremamente semelhantes quanto às propriedades fenotípicas. Eles produzem colônias de 0,5 a $1 \mathrm{~mm}$ de diâmetro, caracterizadas por beta-hemólise e de coloração dourada, ou como descrito na literatura "cor de mel". Após 18 a 24 horas de cultura em ágar sangue (ovino ou bovino $5 \%$ ), em condições de aerobiose e a $37^{\circ} \mathrm{C}$ (Figura 2). Durante o cultivo, o S. equi subesp. equi produz hialuronidase que hidrolisa a cápsula, resultando em colônias mucoides. S. equi subesp. equi também se caracteriza por não fermentar lactose e trealose (RIBEIRO; VARGAS, 2016).

Como fatores de virulência do S. equi subesp. equi podemos citar: cápsula de ácido hialurônico, hialuronidase, estreptolisina, estreptoquinase $S$, proteínas receptoras para a região Fc de imunoglobulinas da classe das IgG's, peptidioglicano, proteína M antifagocitária, hemolisinas e leucotoxinas. Recentemente foram identificadas também a presença de proteína CNE (do inglês collagen binding protein), duas outras proteínas que se ligam à fibronectina (chamadas de cell surface bound fibronectin binding protein e secreted fibronectin binding protein). Todos relacionados com a capacidade da bactéria de aderir às células do hospedeiro (RIBEIRO; VARGAS, 2016).

Figura 2 - Streptococcus equi e meios de ágar sangue mostrando colônia beta- hemolítica

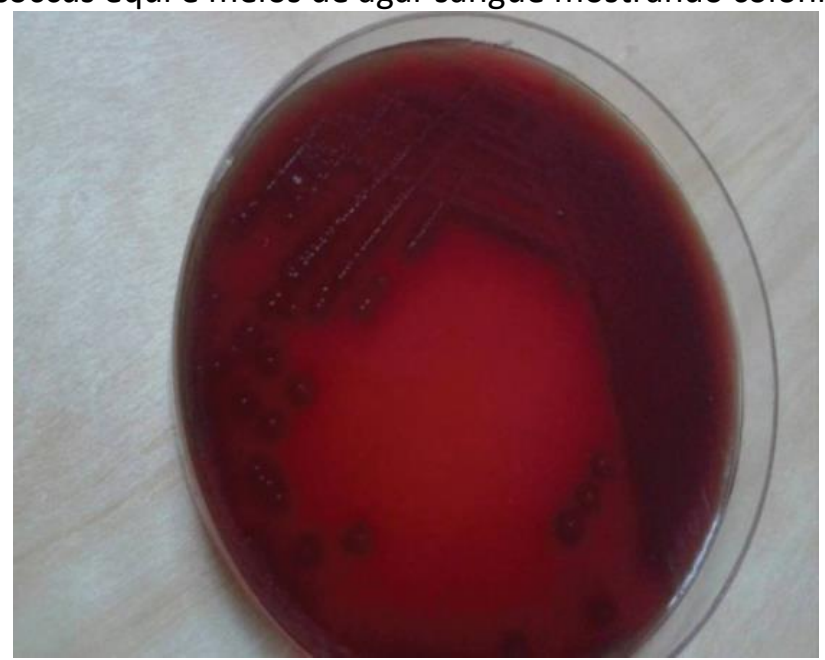

Fonte: Neamat-Allah (2016). 
A cápsula de ácido hialurônico impede a fagocitose pelo fato de reduzir o contato das bactérias com os neutrófilos, também por promover um ambiente redutor, ela protege as 11 proteases e proteínas lábeis de oxigênio. A proteína de ligação de colágeno realiza a adesão da bactéria a fibronectina o que promove a internalização dos estreptococos às células epiteliais. As proteínas de colágeno-like podem ser responsáveis pela resposta imunogênica, elas são expressas durante a infecção. As proteínas de ligação no fibrinogênio fazem uma interação deste com a serina, formando plasmina ativa que hidroxila fibrina, facilitando a disseminação nos tecidos do animal. As proteínas M-like são o principal fator de proteção e de virulência do S. equi, também se ligam ao fibrinogênio evitando a fagocitose. A proteína diminui a atividade bactericida dos neutrófilos dos equinos e a deposição de C3 na superfície da bactéria. A estreptolisina S é responsável pela atividade $\beta$-hemolítica, para exercer essa função ela se liga à albumina o que leva a formação de poros na membrana causando a lise dos glóbulos vermelhos (GUTIÉRREZ, 2013, p.146).

No ambiente, o S. equi subesp. equi pode se manter viável por até três meses desde que haja abrigo da luz solar direta e até 2 meses na vegetação (RIBEIRO; VARGAS, 2016). Contudo, em uma recente pesquisa, Poulin et al. (2017) conseguiram manter o S. equi viável por 72 horas em material orgânico oriundo de baias de cavalos que passou por processo de autoclavagem, em contrapartida o agente manteve-se viável por apenas 12 horas no mesmo material não autoclavado. Dessa maneira os autores sugerem que outros microrganismos presentes do ambiente tenham a capacidade de inativar o S. equi.

\subsection{Epidemiologia}

\subsubsection{Distribuição Geográfica}

A adenite equina figura entre as enfermidades que mais acontecem na criação de equídeos em todo o planeta. Os prejuízos em criatórios e propriedades são atribuídos à suspensão do trabalho dos animais utilizados para tração e transporte, à queda dos rendimentos de animais atletas, além dos gastos com o atendimento clínico veterinário. Ainda é citado o impacto negativo estético pelo enfartamento e abscedação dos linfonodos, e em alguns poucos casos a morte dos animais (RIBEIRO; VARGAS, 2016). 
Apresenta morbidade variável (entre 10 e 100\%), mortalidade de $10 \%$ em animais sem assistência e de 1 a $2 \%$ em animais tratados, e virtude das complicações possíveis. A entrada do agente nas propriedades que criam equídeos se dá pela introdução recente de animais com a doença clínica ou animais portadores que não respeitaram o período de quarentena (RIBEIRO; VARGAS, 2016).

Em um estudo epidemiológico recente, realizado no Rio Grande do Sul, estimouse que a prevalência de equídeos portadores seja de aproximadamente 2,3\% (a nível animal) e 5,86\% (a nível de rebanho) (LIBARDONI et al., 2016). Os animais assintomáticos desenvolvem um papel importantíssimo na disseminação do agente para outros equídeos e com relevância para a introdução da doença em novos países (WALLER, 2016).

\subsubsection{Cadeia Epidemiológica}

As fontes de infecção do garrotilho são os próprios equídeos doentes ou portadores. Como via de eliminação tem-se secreções nasais e o conteúdo de linfonodos (RIBEIRO; VARGAS, 2016). A eliminação do agente ocorre pelas secreções do trato respiratório. No ato de tossir, de relinchar e de espirrar favorecendo a distribuição do agente sob a forma de aerossóis que irão contaminar o ambiente e objetivos e infectar outros animais (THOMASSIAN, 2005). A transmissão de se dá pelo contato direto e indireto. Os meios de transmissão relacionados no contato indireto são água, ração, pastos, cordas, arreios, raspadeiras de crina, tesouras e outros utensílios de manejo animal, além dos calçados e roupas de pessoas que tenham contato com os animais doentes. Os equinos, muares e asininos são os hospedeiros susceptíveis. Acometendo animais entre 1 e 5 anos de idade, especialmente em animais com cerca de 1 ano de idade, o que está relacionado com a faixa etária de desmame dos potros (RIBEIRO; VARGAS, 2016).

\subsection{Patogenia}

Depois de alcançar o organismo animal por via oral ou nasal, o S. equi subesp. equi se aderem às células das mucosas e se multiplicam, atingindo a faringe, tecido tonsilar e tecidos mais profundos (MALLICOTE, 2015). Poucas horas depois, o microrganismo é levado para os linfonodos regionais (retrofaríngeos e submandibulares), onde multiplicam-se extracelularmente. Ocorre atração dos 
neutrófilos e tentativa de fagocitose sem sucesso, devido os fatores de virulência. Essa fase do processo inflamatório é caracterizada pela tentativa de fagocitose pelos neutrófilos sem sucesso, devido os fatores de virulência. Há liberação de enzimas que atraem mais neutrófilos, destruição da parede das células-alvo e morte celular, resultando em um processo altamente piogênico nos focos da infecção (RIBEIRO; VARGAS, 2016).

A febre pode se desenvolver de três a 14 dias pós-infecção, e a circulação bacteriana no sangue de seis a 12 dias pós-infecção. O corrimento nasal pode se dar com dois a três dias e geralmente durando de duas a três semanas (MALLICOTE, 2015). A presença do S. equi subesp. equi nos linfonodos regionais determina quimiotaxia de neutrófilos, com aumento da permeabilidade vascular, formação de edema e abcessos com acúmulo de pus. A coleção purulenta, em alguns animais, é liberada após abscedação dos linfonodos ou quando a região da nasofaríngea é afetada (secreção nasal purulenta). Marcam esse processo o aumento do fibrinogênio e contagem de leucócitos totais (RIBEIRO; VARGAS, 2016). A reinfecção pode ocorrer entre 10 e 20\% dos animais que apresentaram manifestações clínicas, denotando que a imunidade pósinfecção não ocorre na totalidade dos animais expostos (RIBEIRO; VARGAS, 2016).

\subsection{Sinais Clínicos}

O período de incubação da adenite equina compreende variavelmente de uma a três semanas. E, de forma geral, os animais apresentam febre (39 a 41 으), linfoadenopatia (submandibular e retrofaríngea), descarga nasal (de mucosa a mucopurulenta), inapetência e tosse. Há ainda dificuldade respiratória e de deglutição. Ressalta-se que animais que apresentam tosse, essa torna-se mais frequente e produtiva a medida que a doença evolui. Em adultos, a sintomatologia é mais branda: febre transitória e poucas descargas nasais. (RIBEIRO; VARGAS, 2016).

O quadro clínico clássico do garrotilho é o enfartamento de linfonodos da região da cabeça, com destaque para os submandibulares, retrofaríngeos e parotídeos, totalmente em virtude do processo inflamatório local que obstrui o fluxo linfático, tendo ainda edema e intumescimento dos linfonodos (Figura 3). Vale ressaltar que as lesões podem ser uni ou bilaterais (RIBEIRO; VARGAS, 2016). 
Figura 3 - Empiema das bolsas guturais

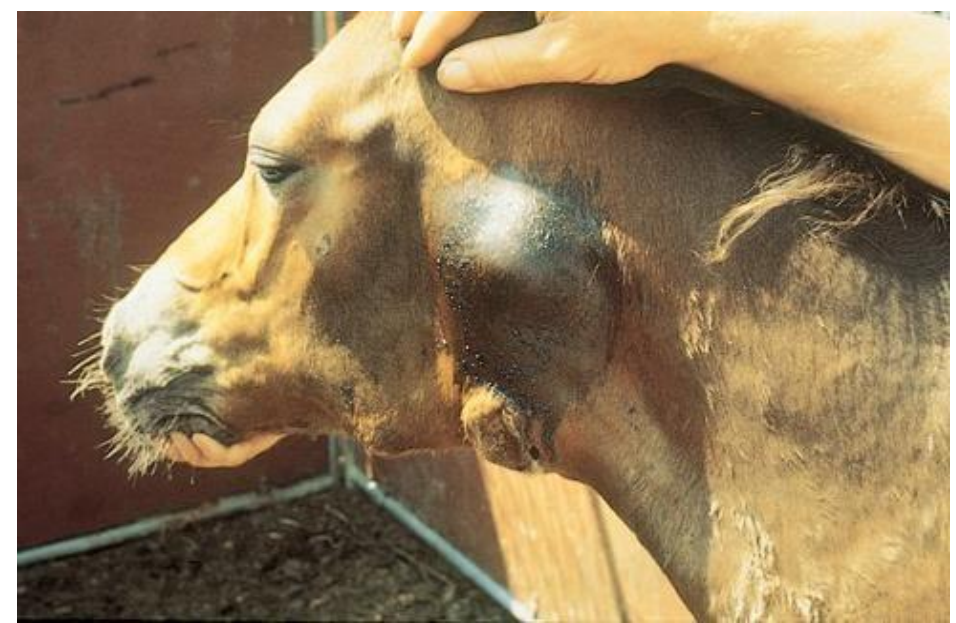

Fonte: Por Fora das Pistas (2019).

As descargas nasais e a supuração os linfonodos se dão poucos dias (de 3 a 14) posterior ao início da febre (Figura 4). A secreção dos linfonodos é espessa, com cor amarela. A linfoadenopatia é seguida de faringite e laringite, que pode resultar em disfagia e dificuldade respiratória. Alguns equídeos desenvolvem também conjuntivite e descargas oculares (RIBEIRO; VARGAS, 2016).

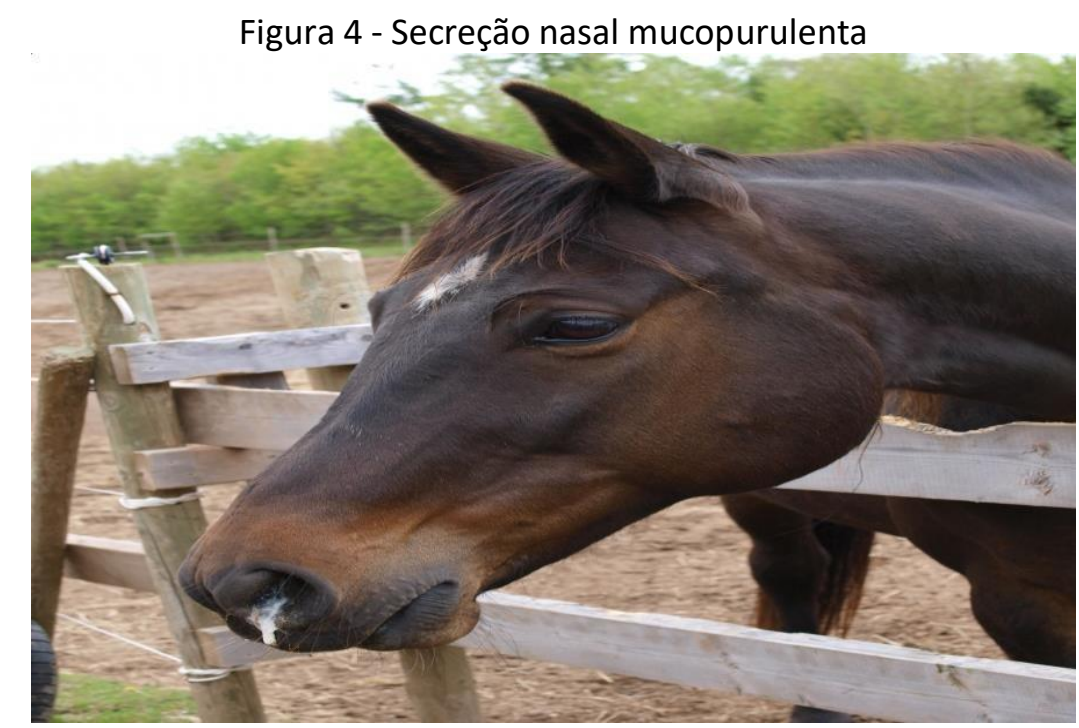

Fonte: Revista Veterinária (2017).

O curso clínico da doença gira em torno de duas a quatro semanas. Podendo resultar na cura espontânea dos animais. Em situações de cronicidade, o animal pode permanecer até três meses doentes. Na convalescência, as descargas nasais findam-se de 3 a 7 semanas após a fase aguda. A mortalidade não ultrapassa a casa dos $10 \%$ e está diretamente relacionada com as complicações da doença (RIBEIRO; VARGAS, 2016). 


\subsection{Complicações Clínicas}

\subsubsection{Septicemia}

Não está totalmente elucidada o meio que leva a disseminação do agente presente nos linfonodos para os demais sistemas, contudo, acredita-se que esteja relacionado com os fatores de virulência, fatores inerentes ao indivíduo (suscetibilidade, higidez, genética) e tratamento tardios ou inadequados. A disseminação do S. equi subesp. equi leva à formação de abscessos em órgãos abdominais, torácicos e no encéfalo. Essa condição é chamada de garrotilho espúrio, bastardo ou metastático. E o animal pode desenvolver pneumonia, artrite, tendinite, nefrite, celulite, panoftalmite, linfadenite mesentérica, encefalite e miocardite. Contudo, a infecção das vias respiratórias inferiores por via hemolinfática ou por aspiração de secreção purulenta dos linfonodos, aparentemente é a principal fontede disseminação da adenite equina. O quadro clínico pulmonar acomete de 30 a 50\% dos casos complicados, e que resulta na morte do animal (RIBEIRO; VARGAS, 2016). A disseminação do S. equi subesp. equi pelo organismo animal geral febre, inapetência, perda de peso e indisposição para o exercício ou trabalho. Abscessos na cavidade abdominal e ruptura dos linfonodos mesentéricos representam sinais agudos de peritonite, observando febre, decúbito, prostação e morte em pouquíssimas horas por choque séptico (RIBEIRO; VARGAS, 2016).

\subsubsection{Empiema da Bolsa Gutural}

Os equídeos possuem duas bolsas guturais estão localizadas na região da cabeça, delimitadas pela base das orelhas, próximas à faringe (Figura 5). E a ruptura do linfonodo retrofaríngeo, leva a disseminação do S. equi subesp. equi para a bolsa gutural, levando a um quadro grave de empiema, com tendência à cronicidade da infecção.

Clinicamente, os equídeos com empiema da bolsa gutural apresentam secreção nasal purulenta profusa e perda de peso. Com a evolução do quadro, pode haver formação de fístulas e abscedação externa do conteúdo da bolsa, com eliminação expressiva de secreção purulenta em vários pontos fistulados abaixo da base das orelhas. Alguns animais podem progredir para casos crônicos, desenvolvendo condroides repletos de S. equi subesp. equi (RIBEIRO; VARGAS, 2016). 
Figura 5 - Localização anatômica da bolsa gutural em equinos

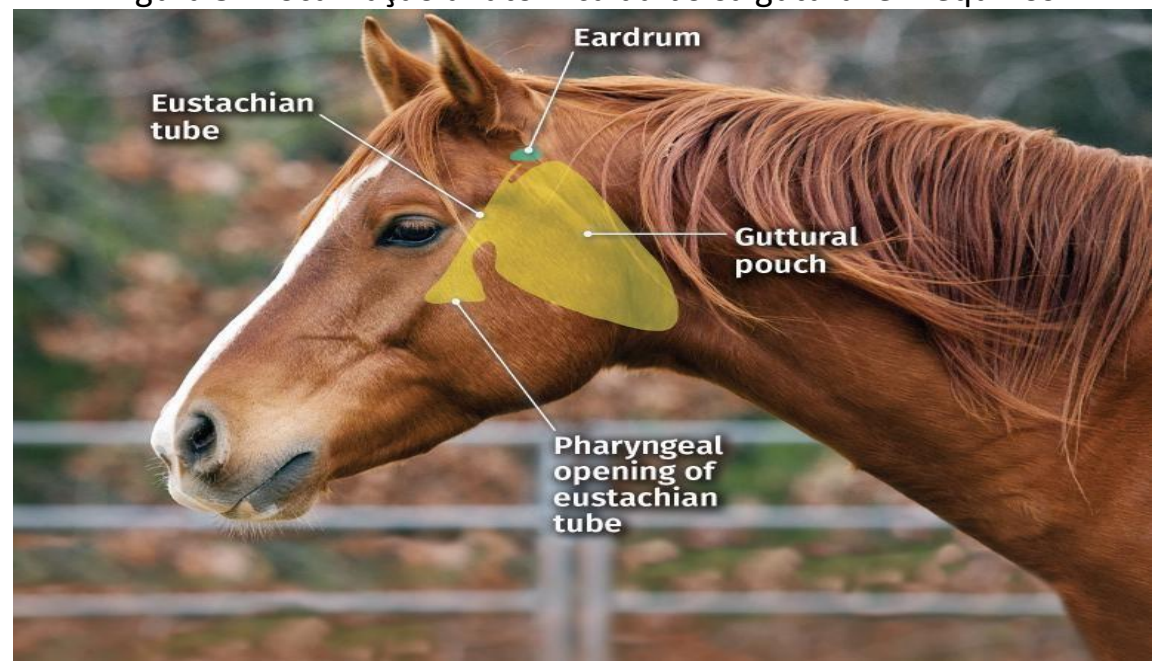

Fonte: EVANS (2018).

\subsubsection{Púrpura Hemorrágica}

Essa complicação do garrotilho decorre do desenvolvimento de uma reação imunomediada. Porém não há um esclarecimento da sua patogênese, mas sugere-se que ela seja secundária a uma reação exacerbada de equídeos infectados com linhagens virulentas do S. equi subesp. equi, levando ao acúmulo de imunocomplexos na parede dos vasos sanguíneos, resultando em vasculite e aumento da permeabilidade vascular. Clinicamente, observa-se animais com dificuldade respiratória, taquicardia, edema, petéquias e equimoses em mucosas, conjuntivas e serosas, evoluindo para morte ocasional. Em situação mais graves, os equídeos apresentam sinais de cólicas por vasculite no trato digestório, além de desprendimento da pele acima dos cascos (RIBEIRO; VARGAS, 2016).

\subsubsection{Outras Complicações Clínicas}

Muito raramente há disseminação dos estreptococos para o sistema nervoso central. Quando isso acontece, resulta em encefalite pela hiperestesia, apoio da cabeça em obstáculos, andar em círculos, tremores, excitação, ataxia, rigidez da nuca, deambulação e paralisia dos membros. A compressão ou lesão do nervo laríngeo, pode levar à hemiplegia laríngea, exacerbando a dificuldade respiratória dos equídeos (RIBEIRO; VARGAS, 2016).

Rabdomiólise também é possível de acontecer decorrente do garrotilho. Essa complicação costuma ser observado em cavalos da raça Quarto de Milha, manifestada por atrofia muscular progressiva. Alguns animais também apresentam miosite com 
atrofia muscular na região glútea, quadros de glomerulonefrite e miocardite (RIBEIRO; VARGAS, 2016).

S. equi subesp equi e S. equi subesp. zooepidemicus têm sido isolados de éguas com mastite clínica e subclínica. Os sinais clínicos envolvem edema, hiperemia e dor ao toque, além do leite com coloração e aspectos alterados. Com o agravamento do quadro, nota-se agalaxia, febre, anorexia e letargia (RIBEIRO; VARGAS, 2016).

\subsection{Diagnóstico}

Para a confirmação de um caso de adenite equina, é importante levar em consideração os achados clínico-epidemiológicos e apoiá-los em exames complementares (RIBEIRO; VARGAS, 2016). Fonseca et al. (2010) resumem que o diagnóstico confirmatório da adenite equina deve se dar pelos sinais clínicos, características epidemiológicas da doença, pela demonstração do S. equi em esfregaços do material purulento dos linfonodos ou secreção nasal e pelo isolamento do agente a partir do cultivo microbiológico (Figura 6).

Figura 6 - Corrimento nasal mucopurulento originário de linfonodo retrofaríngeo infectado por adenite equina

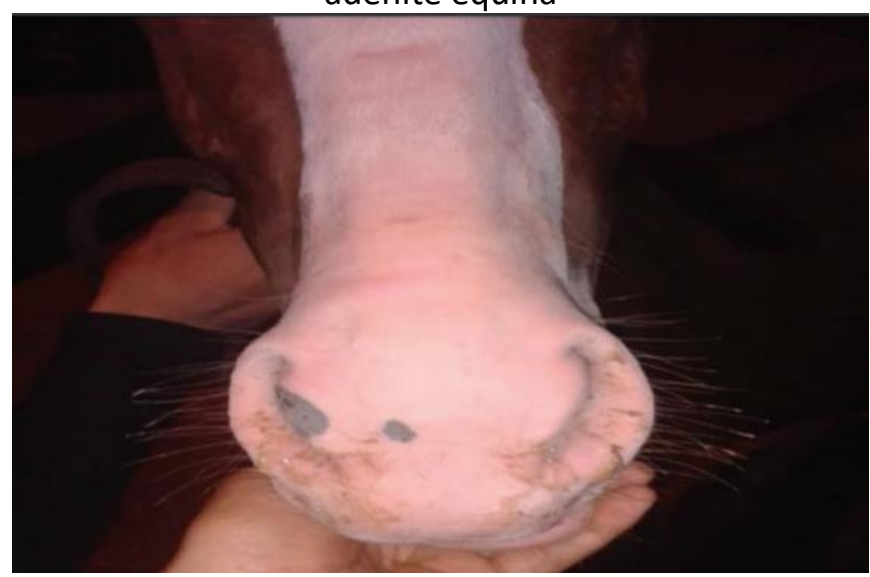

Fonte: Neamat-Allah (2016).

A doença clínica ocorre com maior frequência em potros na fase do desmame. $E$ nota-se sinais de febre, inapetência ou anorexia, enfartamento dos linfonodos cervicais e secreções nasais purulentas. À palpação, os linfonodos que drenam a região da cabeça ficam intumescidos, quentes e sensíveis ao toque (doloridos). Um exame auxiliar seria o diagnóstico por imagem radiográfico ou endoscopia para observação do enfartamento dos linfonodos. Vale lembrar que diagnosticar os quadros de empiema e de condroides só é possível pela endoscopia (Figura 7) (RIBEIRO; VARGAS, 2016). 


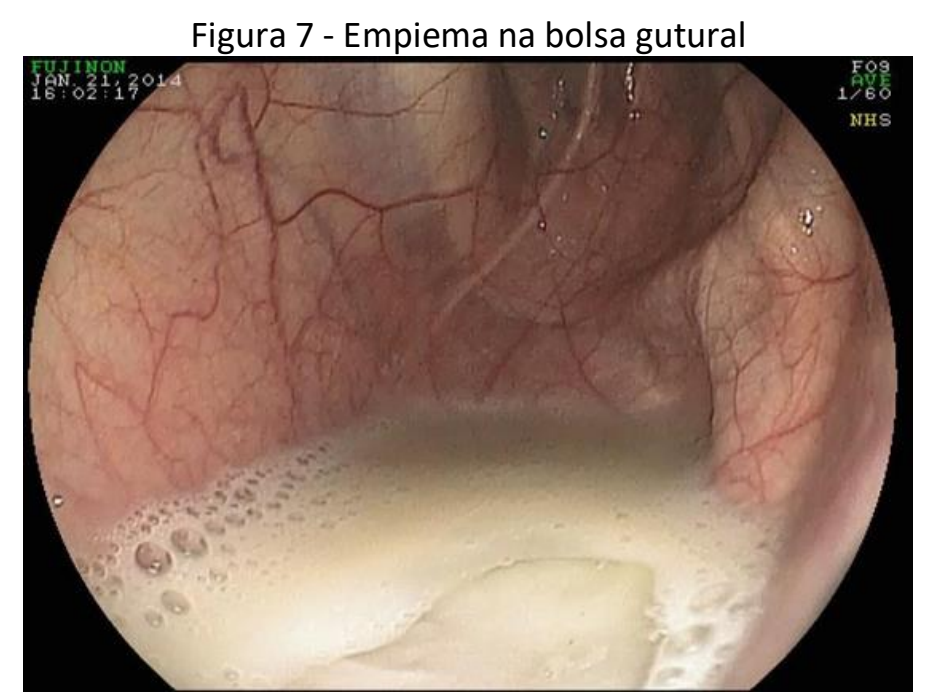

Fonte: PANSANI et al. (2008).

Nos exames hematológicos é possível observar leucocitose com neutrofilia, aumento de fibrinogênio, anemias em graus variáveis, hiperproteinemia (em casos crônicos) e aumento sérico de creatinoquinase (em animais com miopatias (RIBEIRO; VARGAS, 2016). O exame microbiológico é considerado o principal método de rotina, devido sua praticidade, resultado acurado e custo acessível. O isolamento se dá a partir secreção purulena coletado dos linfonodos, secreções nasais e bolsa gutural, de lavados nasais ou de órgãos após a necropsia. É importante realizar os testes bioquímicos para diferenciação das subespécies de S. equi (RIBEIRO; VARGAS, 2016). Para esse teste semeia-se a amostra colhida em ágar gel sangue enriquecido com colistina e ácido nalidíxico, incubando a $37^{\circ} \mathrm{C}$ em overnight numa atmosfera de $5 \%$ de $\mathrm{CO} 2$ (Figura 8) (WALLER, 2014). 
Figura 8 - Streptococcus equi

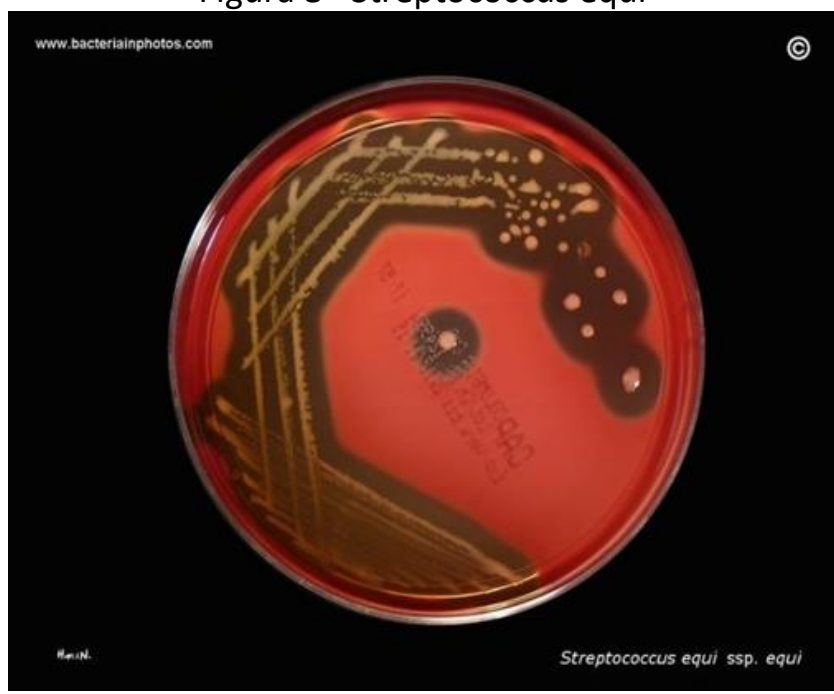

Fonte: Bacteria in fotos (2019)

O veterinário também pode lançar mão da citologia, realizada mediante aspiração por agulha fina dos linfonodos não supurados e observação no microscópio da estrutura dos estreptococos. Há ainda a possibilidade de se realizar biopsia de animais com alterações musculares (RIBEIRO; VARGAS, 2016).

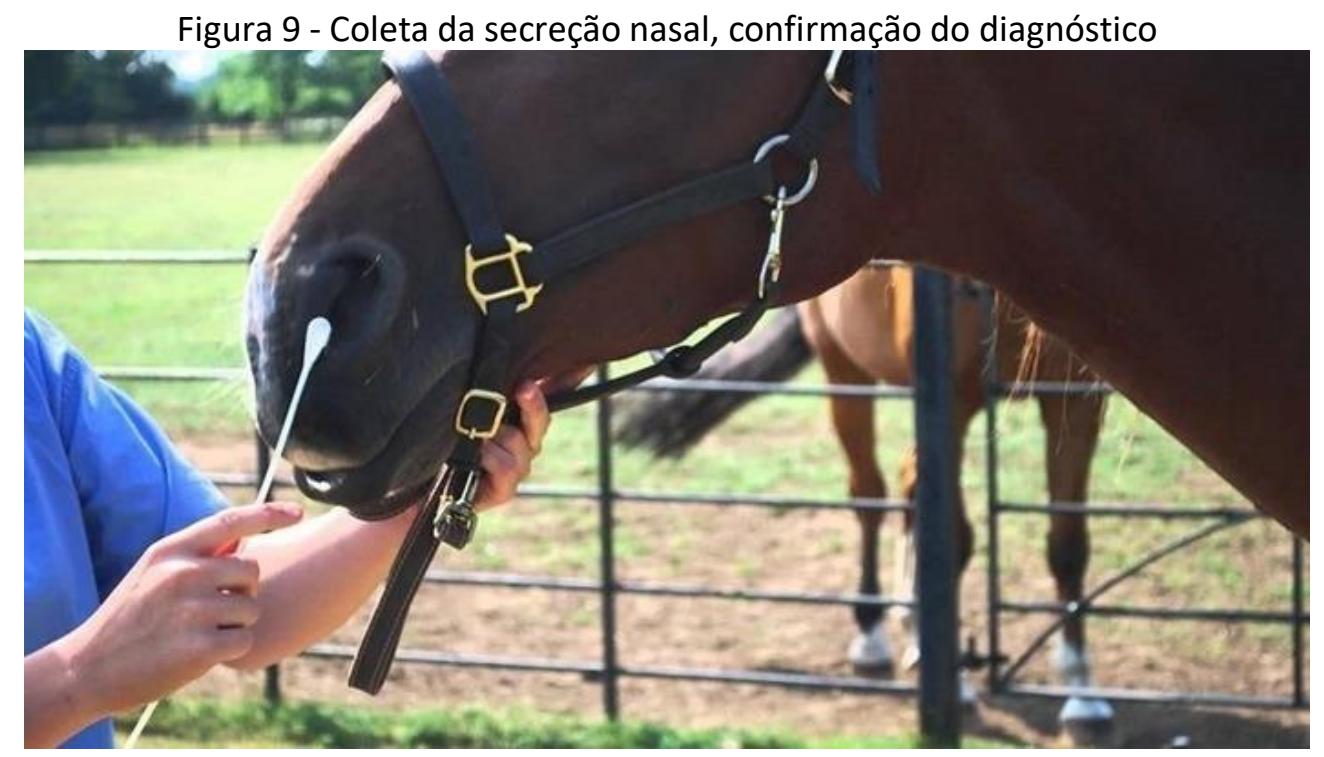

Fonte: Fernandes (2019).

Como sorodiagnóstico, está disponível o ELISA. Na prática esse teste tem sido utilizado para determinar a resposta sérica de animais vacinados, animais em fase crônica ou com púrpura hemorrágica. Um detalhe é que esse teste não distingue animais infectados de vacinados (RIBEIRO; VARGAS, 2016).

Nos últimos anos, as técnicas moleculares têm-se mostrado promissoras para diagnóstico do garrotilho. Sugerindo a associação de PCR (reação em cadeia pela 
polimerase) com o cultivo microbiológico. A PCR tem sido adotada em programas de controle em propriedades endêmicas (RIBEIRO; VARGAS, 2016).

No exame post mortem de animais com complicações relacionadas a septicemia são observados pneumonia purulenta a necrótica, pleurite, hepatite, nefrite, linfadenite, artrite e miocardite. E os exames histopatológicos revelam intenso processo inflamatório com infiltrado polimorfonucleares, debris celulares e material purulento (Figuras 10, 11 e 12) (RIBEIRO; VARGAS, 2016).

Figura 10 - Detalhe microscópico da bolsa gutural epitélio de uma cultura de órgãos infectada com S. equi equi e incubado por 4 horas. Após coloração de Gram bacteriana pode ser observado um apego às células epiteliais. S. equi equi é indicado em alguns sites de aderência (seta). (100x ampliação)

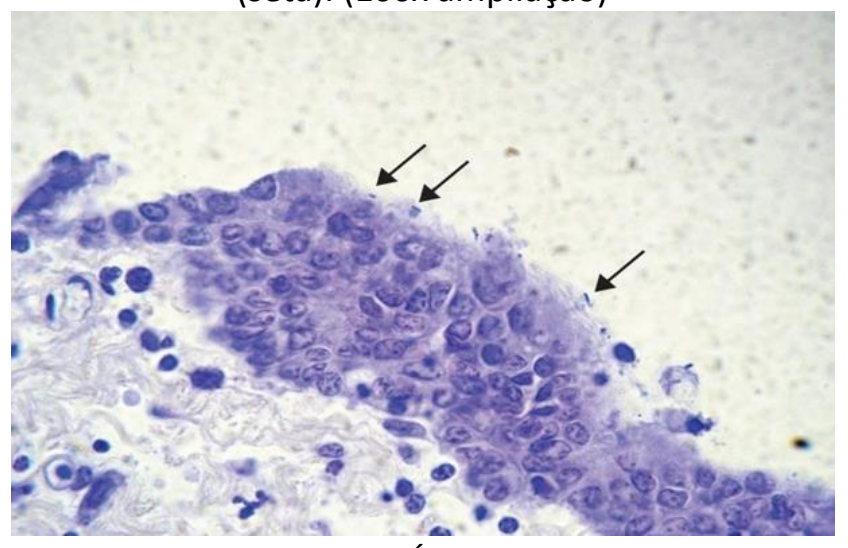

Fonte: GUTIÉRREZ (2013).

Figura 11 - A adesão das bactérias à bolsa gutural em cultura de órgãos infectados com S. equi equi após 4 horas de incubação. Bactérias evidenciadas pela coloração de Gram grupos em

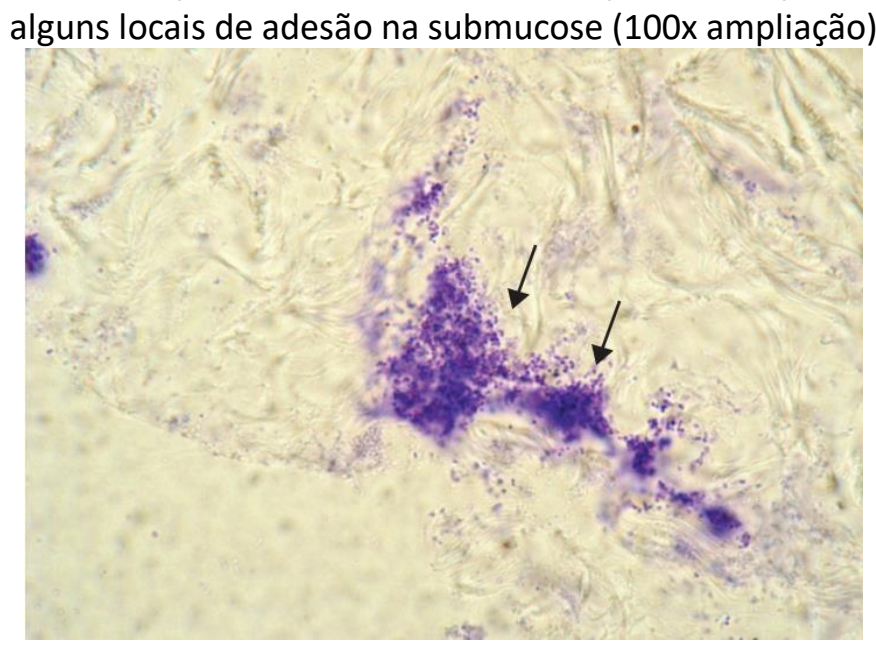

Fonte: GUTIÉRREZ (2013). 
Figura 12 - Inflamação crônica da retrofaringe de um cavalo. O programa de coloração com hematoxilina-eosina infiltração de monócitos no nó retrofaríngeo post-mortem (ampliação de 100x)

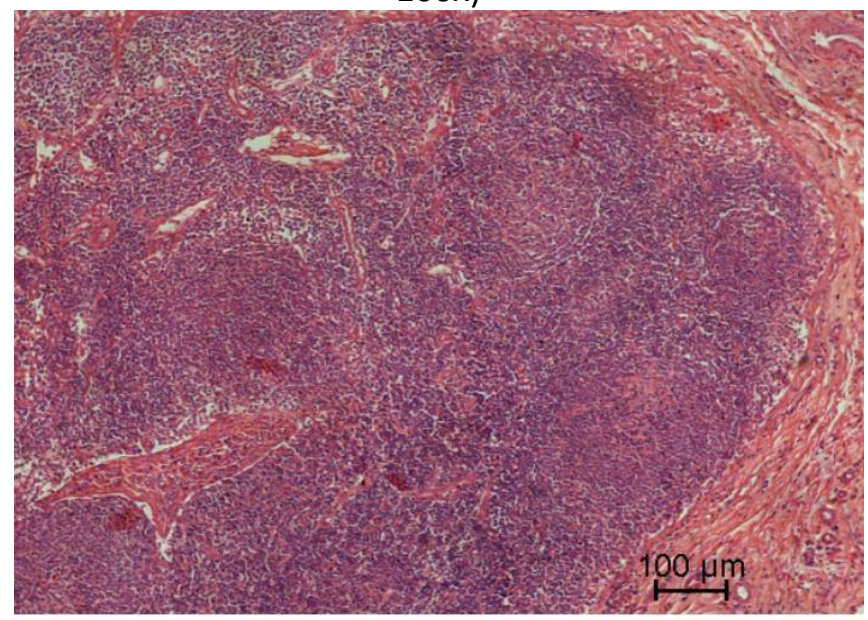

Fonte: GUTIÉRREZ (2013).

\subsection{Diagnóstico Diferencial}

Em animais de até seis meses de idade, a adenite equina pode ser confundida com rodococose e influenza equina. Já em adultos, deve ser diferenciada de doenças como arterite viral, herpesvírus equino tipo 1 e tipo 4, influenza e mormo (RIBEIRO; VARGAS, 2016). Gutiérrez (2013) adicionalmente informa que o diagnóstico diferencial também precisa levar em consideração doenças que acometem o trato respiratório superior de equídeos. O emagrecimento progressivo de caráter crônico pode ser muito comum com aa Anemia Infecciosa Equina, neoplasias, nutrição deficiente e parasitismo.

\subsection{Tratamento}

O tratamento normalmente é realizado com antibiótico terapia e terapia suporte, sendo que na fase inicial onde é caracterizado por febre, depressão e anorexia o uso penicilina $\mathrm{G}$ via intramuscular, por 5 a 10 dias é eficiente, impedindo a formação de abscessos (MORAES et al., 2009).

Após o enfartamento dos linfonodos o tratamento se torna ineficaz, o antibiótico chega em baixos níveis devido à pouca vascularização no abcesso (HARRINGTON et al., 2002). Deve ser aplicado pomadas rubefacientes para acelerar a maturação do abscesso e antecipar a supuração em seguida fazer a drenagem e a limpeza no local utilizando iodo impedindo infecções secundárias (SWEENEY et al., 2005). 


\subsection{Prognóstico}

Em 80 a 90\% dos casos, o processo patogênico é benigno, ocorrendo cura clínica dos animais com ou sem instituição do tratamento. No entanto, entre 10 e $20 \%$ dos casos ocorrem complicações da doença como resultado da disseminação linfo-hemática do S. equi subesp. equi, podendo haver septicemia, abscessos em vísceras, reações imunomediadas, miosites e empiema da bolsa gutural (RIBEIRO; VARGAS, 2016).

\subsection{Medidas de Controle e Prevenção}

Em situações de surtos epidêmicos de adenite equina, a primeira ação é isolar tanto os equídeos enfermos quanto os contactantes. Evitar o uso comedouros ou bebedouros de uso comum, além de remover toda matéria orgânica (limpeza mecânica) e na sequência fazer o uso do desinfetante. É importante não transitar com animais e pessoas em locais ondem haja focos do garrotilho. Submeter a quarentena novos animais antes de serem introduzidos à tropa (GUTIÉRREZ, 2013). A estrutura física da propriedade deve passar por processos de limpeza e desinfecção. Durante a rotina dos criatórios, primeiro deve-se realizar o manejo dos animais sadios e somente no final dos animais infectados. Uma dica é trocar as vestimentas e sapatos após a lida com os doentes. A melhor maneira de evitar a adenite equina é por meio da vacinação dos equídeos, que confere considerável proteção e promove imunidade de longa duração (WALLER, 2014).

\subsubsection{Vacina}

Existem muitos grupos de pesquisa em vários países que objetivam desenvolver uma vacina mais segura e mais efetiva contra o garrotilho. Pensar no controle dessa doença sem uma vacina altamente efetiva é muito complicado (GUTIÉRREZ, 2013). Recentemente, um novo imunobiológico (vacina recombinante) foi testado utilizando diversas proteínas de S. equi. Robinson et al. (2018) afirmam que essa vacina apresentou bons resultados, que incluem aumento significativo da eficácia da vacina em indivíduos desafiados à infecção natural e a não produção de efeitos adversos significativos.

\subsection{Aspectos Relacionados à Saúde Pública}

Raramente seres humanos se infectam com $S$. equi subesp equi e S. equi subesp. zooepidemicus. Mas quando essa condição acontece, são descritas bacteremia, 
abscessos, artrite, nefrite e meningite. Trata-se de uma situação ocupacional em pessoas que possuem estreita relação com equídeos, relatada em médicos-veterinários, patologistas, tratadores e criadores, além de indivíduos debilitados. A transmissão se dá pela inalação de aerossóis ou por contata com material purulento dos equídeos infectados. Desta maneira, recomenda-se evitar o manuseio ou realizar o exame clínico sem luvas, principalmente de animais que apresentem supuração de linfonodos, empiema de bolsa gutural e abcessos. As recomendações se estendem para as necropsias de animais positivos para adenite equina, com intuito de minimizar os riscos de infecção (RIBEIRO; VARGAS, 2016).

\section{CONSIDERAÇÕES FINAIS}

Através desse estudo, foi possível perceber que a Adenite é uma das principais doenças bacterianas do trato respiratório que podem ocasionar prejuízos no comércio equino. Destacando-se, que essa doença possui um elevado índice de morbidade e grande potencial em ocasionar sequelas ao animal.

O diagnóstico precoce e o tratamento adequado, são de extrema importância para evitar perdas econômicas e preservar a saúde do animal. Portanto, o profissional capacitado para identificar a doença e determinar o tratamento é o médico veterinário, o qual possui amplo conhecimento acerca da doença, diagnosticando-a e escolhendo a terapêutica adequada, de acordo com o estágio da doença.

Nota-se também a grande relevância dos estudos realizados nessa área, diante a importância da doença frente ao comércio, o qual aumenta cada dia mais e consequentemente agride o animal devido as mudanças em seu estilo de vida. Dessa forma, sugere-se a realização de novas pesquisas relacionadas a Adenite equina, visando aumentar o conhecimento dos leitores, principalmente profissionais da área.

\section{REFERÊNCIAS}

AMARAL, G.A.C.; MELLO, F.C.; PELEGRINO, R.C.; TOLEDO, E.A.P. Tratamento de Garrotilho em Equino. Revista Científica Eletrônica de Medicina Veterinária, v.4, n.10, 2018.

Bacteria in fotos. 2019. http://www.bacteriainphotos.com/streptococcus\%20equi.html 
EVANS, E. Getting Ahead of Strangles. Horse Journals. Disponível em https://www.horsejournals.com/horse-care/illness-injury/diseases/gettingahead- strangles

Fernandes, G. Adenite Equina "Garrotilho". 2019. https://univitta.net/blog/adenite-equina-garrotilho

FONSECA, R.D. et al. Garrotilho e mormo em equídeos - Revisão de literatura. PUBVET, Londrina, V. 4, N. 38, Ed. 143, Art. 964, 2010.

GUTIÉRREZ, María Patricia Arias. Strangles: the most prevalent infectious respiratory disease in horses worldwide. Revista Ces Medicina Veterinaria y Zootecnia, Medellín, v. 8, n. 1, p.143-159, jun. 2013.

HOLDEN, M. T. G. et al. Genomic evidence for the evolution of Streptococcus equi host restriction, increased virulence, and genetic exchange with human pathogens. PLoS Pathogens, v. 5, n. 3, 2009.

PANSANI, M.A.; et al. Causa e tratamento de garrotilho em equinos. REVISTA CIENTÍFICA ELETÔNICA DE MEDICINA VETERINÁRIA; Ano VI - Número 10 - Janeiro de 2008 - Periódicos Semestral

LIBARDONI, F. et al. Prevalence of Streptococcus equi subsp. equi in horses and associated risk factors in the State of Rio Grande do Sul, Brazil. Research in Veterinary Science, v. 104, p. 53-57, 2016.

LIBARDONI, Felipe et al. Equinos portadores de Streptococcus equi subespécie equi: Prevalência, fatores de risco e caracterização de alelos seM. 2015. Tese de Doutorado. Universidade Federal de Santa Maria.

MALLICOTE, M. Update on Streptococcus equi subsp equi Infections. Veterinary Clinics of North America: Equine Practice, [s.i], v. 31, n. 1, p.27- 41, abr. 2015.

MORAES, C. M. et al. Adenite equina: sua etiologia, diagnóstico e controle. Cienc. Rural [online]. 2009, vol.39, n.6 [cited 2019-12-04], pp.1944- 1952.

NEAMAT-ALLAH ANF, EL DAMATY HM (2016) Strangles in Arabian horses in Egypt: Clinical, epidemiological, hematological, and biochemical aspects, Veterinary World, 9(8): 820-826. 2016.

POULIN, A. et al. Elimination of equine streptococci from soiled horse bedding. Workshop: Getting to Grips with Strangles and other Streptococcal Diseases. Anais...Gallatin Gateway, Montana: Havemeyer Foundation, Inc., 2017.

Por fora das Pista. http://www.porforadaspistas.com.br/entenda-o-famoso- garrotilhoequino/ 
Revista Veterinária. http://www.revistaveterinaria.com.br/doenca-respiratoriadictiocaulose-equina/

RIBEIRO, M.G.; VARGAS, A. C. Garrotilho. In: MEGID, J.; RIBEIRO, M. G.; PAES, A. C. Doenças infecciosas em animais de produção e companhia. 1. ed. Rio de Janeiro: Roca, 2016. p. 327-339.

ROBINSON, C. et al. Genome decay of $S$. equi and its practical implications: the requirement for multiple diagnostic targets. 10th IEIDC Abstracts / Journal of Equine Veterinary Science. Anais...Elsevier Ltd, 2016.

ROBINSON, C.; FRYKBERG, L.; FLOCK, M.; GUSS, B.; WALLER, A.; FLOCK, J.I. STRANGVAC: A recombinant fusion protein vaccine that protects against strangles, caused by Streptococcus equi. Vaccine, 36: 1484-1490, 2018.

SILVA, M.S; VARGAS, A.C. Adenite Equina - Aspectos Clínicos, agentes etiológicos e métodos diagnósticos. Arquivo do Instituto de Biologia, São Paulo, v.73, n.4, p.493-498, 2016.

THOMASSIAN, A. Enfermidades dos cavalos. 3. Ed. São Paulo: Livraria Varela, 2005.

WALLER, A. S. New Perspectives for the Diagnosis, Control , Treatment, and Prevention of Strangles in Horses. Veterinary Clinics of North America: Equine Practice, [s. L.], v. 30, n. 3, p.591-607, dez. 2014.

WALLER, A. S. Strangles: a pathogenic legacy of the war horse. Veterinary Record, v. 178, p. 91-92, 2016. 


\section{CAPÍTULO III}

\section{BRUCELOSE BOVINA - ASPECTOS EPIDEMIOLÓGICOS E REPRODUTIVOS}

DDI: 10.51859/amplla.pdi443.1121-3

Karoline Silva Melo ${ }^{1}$

Carolina de Alvarenga $\mathrm{Cruz}^{2}$

Raphaella Barbosa Meirelles-Bartoli ${ }^{3}$

Eric Mateus Nascimento de Paula ${ }^{4}$

\footnotetext{
Médica Veterinária Autônoma. Egressa do Curso de Medicina Veterinária do Centro Universitário de Mineiros UNIFIMES.

${ }^{2}$ Médica Veterinária Autônoma. Doutora em Medicina Veterinária pela Unesp/FCAV.

${ }^{3}$ Docente do Curso de Medicina Veterinária da Universidade Federal de Jataí - UFJ.

${ }^{4}$ Docente do Curso de Medicina Veterinária do Centro Universitário de Mineiros - UNIFIMES.
}

\section{RESUMO}

A brucelose é uma antropozoonose de desenvolvimento crônico, instigado por uma bactéria intracelular facultativa do gênero Brucella, que compromete especialmente os conjuntos reprodutivo e osteoarticular. Os aspectos reprodutivos da brucelose bovina, está ligado diretamente ao abortamento, o qual remete-se à expulsão do feto, variavelmente entre o período de 42 a 280 dias de gestação, independente se vivo ou morto. Dentre as causas da enfermidade, destacam-se as bactérias, e os aspectos ambientais. A brucelose é uma doença de visibilidade, e com isso ressalta-se a importância de ações de educação para o controle e erradicação desta zoonose. Diante disso, foi criado pelo MAPA- Ministério da Agricultura, Pecuária e abastecimento, o PNCEBT- Programa Nacional de Controle e Erradicação da Brucelose e Tuberculose, a fim de diminuir e/ou erradicar sua prevalência; contando com amostragem de dados, a fim de que, conheçam mesmo de que de forma breve a importância desta doença à saúde pública, já que o possível risco para a saúde humana é subestimado, pelo problema ser de difícil diagnóstico.

Palavras-chave: Abortamento. Brucella. Epidemiologia. Zoonose.

\section{INTRODUÇÃO}

O mercado bovino brasileiro, atualmente, é um dos principais responsáveis pela produção e comércio de carne mundial, resultado de um processo de evolução, tanto na produtividade quanto na qualidade. Haja vista que, no período 2015, o Brasil ocupou 
o ranking de maior rebanho bovino mundial, com cerca de 209 milhões de cabeças, e segundo maior consumidor de carne com $38,6 \mathrm{~kg} /$ habitante/ano e o segundo maior exportador com abrangência de 1,9 milhões toneladas.

A exportação de carne bovina, representa 3\% das exportações nacionais e um ganho de 6 bilhões de reais, porém por mais que existam ferramentas de qualidade, a pecuária não é uma atividade que se mantém sustentável por si só. Para o produtor é fundamental que se relacione a produção com manejo e boas práticas, pois a incidência de enfermidades, o manejo incorreto, podem favorecer a criação de barreiras sanitárias, prejudicando o produto, como um todo.

Para melhorar os índices zootécnicos de uma propriedade é necessário que se conheça suas necessidades, pois o risco de não se manter cuidados sanitários, está ligado diretamente às perdas de produção e econômicas.

As doenças infecciosas responsáveis por aborto, fazem parte de algumas classes, dentre elas, virais com Complexo Herpes Vírus, Diarréia Viral Bovina, Rinotraqueíte Infecciosa Bovina, Vírus da língua azul, e Vírus da febre aftosa; dos protozoários com Neosporose, e Tricomoníase; dos fungicos representado pelo aborto micótico; e a bacteriana com Anaplasmose, Brucelose, Campilobacteriose, Leptospirose, e os agentes como Chlamydia sp, Corynebacterium pyogenes, Haemophilus sp, Listeria monocytogenes, Mycoplasma sp, e Staphylococcus aureus.

A brucelose, possui uma vasta quantidade de hospedeiros, causando problemas, principalmente de ordem reprodutiva em bovinos, onde as fêmeas em gestação, são a categoria mais susceptível, e os touros possuem pouca importância.

Este trabalho visa abordar os aspectos epidemiológicos e reprodutivos da brucelose na espécie bovina, destacando a enfermidade tanto para bovinos, quanto sua relação com a saúde pública.

\section{REVISÃO DE LITERATURA}

\subsection{Definição}

A brucelose é uma antropozoonose sistêmica com caráter crônico e distribuição

mundial, caracterizada por abortos seguidos de retenção placentária e metrite, e acometendo também o sistema osteoarticular de bovinos (MEGID, 2016). De acordo 
com Ribeiro (2000), estima-se uma queda na produção de 20 - 25\% quando o diagnóstico é positivo à enfermidade, devido aos abortamentos e problemas de fertilidade, dependendo do estado imunológico do rebanho.

Os abortos acontecem por volta do 5ㅇ ou 6ㅇ mês de gestação. Podendo ocasionar casos de esterilidade ou morte. Nos machos, a Brucella abortus pode causar orquite e, com pouca frequência, sinovite não supurativa (RIET CORREA et al., 2001).

A brucelose bovina afeta diretamente a saúde pública, atingindo profissionais e trabalhadores, que atuam na área de saúde animal, se fazendo assim conhecida como doença ocupacional (TOCANTINS et al., 2000).

\subsection{Histórico}

Sabe-se do relato de identificação de lesões típicas de brucelose em esqueletos na época de 79 a.C, o que comprova caráter antigo desta enfermidade; na época do Império Romano, essa doença se caracterizou de forma endêmica e se expandiu entre os habitantes da ilha de Malta, e o sintoma era uma febre, que poderia, nos estágios mais graves, ocasionar à morte (MEGID, 2016).

Descrita pela primeira vez em humanos, quando associada ao consumo de leite de cabras, e teve seu agente isolado pela primeira vez a partir do baço de um soldado Britânico que morreu de febre de malta em 1887.Como sinonímia a doença também era conhecida como febre ondulante, devido as características que o paciente apresentava. Posteriormente, foi demonstrado a natureza biológica da B. melitensis, isolando-as de leite de cabra (NICOLETTI, 2002; POESTER et al., 2009; MEGID, 2016).

Em meados de 1895, um veterinário conhecido por Bernhard Bang, isolou um microrganismo do útero e membranas fetais resultantes do aborto de vacas, identificando-o como Bacillus abortus (NICOLETTI, 2002; POESTER et al., 2009).

\subsection{Agente Etiológico}

Atualmente são reconhecidas dez espécies de Brucella, sendo: B. melitensis, em caprinos e ovinos, onde aja vista ser a mais patogênica em relação aos humanos, porém inexistente no Brasil; B. abortus com bovinos e bubalinos; B. suis, suínos, lebres, e roedores; B. neotomae representado pelo rato do deserto; B. canis nos caninos; B. ovis em ovinos; B. ceti com cetáceos; B. pinnipedialis com os pinípedes; B. microti representado por sua preferência em camundongo de campo, e por último na classe de 
caracterização, a Brucella inopinata, sendo descoberta através de uma infecção de implante mamário em humanos (MEDIG, 2016).

São pequenos cocobacilos bacterianos gram-negativos não capsulados, sem capacidade de locomoção e de formar esporos, classificada no filo Proteobacteria, classe Alphaproteobactéria, na ordem Rhizobiales, família Brucellaceae e no gênero Brucella (PESSEGUEIRO, 2003; PROBERT et al., 2004).

A Brucella mede cerca de 0,5 a $0,7 \mu \mathrm{m}$ de diâmetro por 0,6 à 1,5 de largura, sendo um microrganismo isolado em diversos tipos de cultura, às vezes em cadeias curtas e que atualmente já se encontra presença de flagelos (MEGID, 2016).

Segundo GOMES, (2007), todas as espécies podem sofrer lise, por meio da pasteurização, o que dura cerca de 10 à 15 minutos; sendo assim, podem ser destruídas rapidamente por desinfetantes comuns. O gênero Brucella é capaz de sobreviver em cadáveres e tecidos contaminados por até dois anos; a B. abortus não é resistente à luz solar, apresenta predileção ao inverno, mantém-se viva no leite, porém pode ser destruída pela pasteurização (MERIAL, 2017).

\subsection{Epidemiologia}

\subsubsection{Distribuição Geográfica}

A infecção por Brucella sp. apresenta distribuição mundial (ANTONIASSI, 2007). Estudos apontam que em 2003 alguns países de forma sistemática, já estariam na condição de erradicado, tais como: Austrália em 1989; Nova Zelândia e Canadá em 1985; já outros estavam em fase de eliminação como, por exemplo: Cuba, Uruguai, França. Alguns países iniciaram seus programas há poucos anos e outros ainda encontram problemas para a implantação (SILVA et al., 2008).

De acordo com VERONESI et al., (1996), a brucelose bovina parece estar presente por todo o território brasileiro, com sua prevalência dependendo da região estudada. Em meados de 1975, foram observadas tais porcentagens: Sudeste, 7,5\%; Centro-Oeste, 6,8\%; Norte, 4,1; Sul, 4\%, e Nordeste, 2,5\%; seguido da prevalência dos positivos entre 4\% e 5\% entre os anos 1988 e 1998. 


\subsubsection{Cadeia Epidemiológica}

\subsubsection{Fonte de Infecção}

Não só os bovinos, como também outras espécies podem introduzir o agente numa criação, como, por exemplo, os suínos, ovinos, caprinos, equinos, cães e gatos. Os vaqueiros infectados por brucelose também representam um perigo para as criações não infectadas (BEER, 1988).

\subsubsection{Vias de eliminação}

$\mathrm{O}$ agente pode ser eliminado por diversas vias, tais como membranas, líquidos fetais, feto, secreções vaginais, leite, e até mesmo o sêmen; as que ocupam a frente são os fetos e anexos fetais, em razão da importância na manutenção da brucella, ocorrendo precipuamente após parto ou abortamento, seguido das descargas uterinas, e via leite (MEGID, MATHIAS, 2015). Na monta natural, o sêmen é depositado na vagina, onde há defesas inespecíficas que dificultam o processo (BRASIL, 2006).

\subsubsection{Meios de Transmissão}

Os principais meios de transmissão estão relacionados a água e alimentos; seguidos posteriormente de pastagens, instalações, aerossóis em ambientes fechados, ato de lambeduras entre doentes e sadios, e cobertura por touro infectado, onde praticamente não há importância, porém quando por inseminação artificial é de tamanha preocupação, pois não há barreiras que bloqueiem sua proliferação (MEGID, 2016; ANTUNES; EMBRAPA, 2017).

\subsubsection{Porta de entrada}

A brucella abortus, tem como principal porta de entrada, a mucosa gastrintestinal, visto que pela mucosa vaginal a quantidade de microrganismos deve ser exorbitante (BEER, 1988). A mucosa nasal, assim como conjuntiva, genital e pele também podem ser, desde que com solução de continuidade (BRASIL, 2006).

\subsubsection{Hospedeiros Susceptíveis}

A B. abortus, também pode infectar outras espécies domésticas, tais como bubalinos (criação que vem crescendo ao passar dos anos), cães, caprinos, equídeos, suínos e ovinos; porém aos suínos é transpassada de maneira transitória não por transmissão direta. A classe em que a enfermidade estabelece afinidade são as vacas, 
especialmente em períodos gestacionais, porém convém apontar que ainda possa haver variações individuais do rebanho mesmo que em menores prevalências (MEGID, 2016).

Tanto fêmeas quanto machos, são predispostos ao microrganismo, porém apresentam predileção as fêmeas em idade de reprodução e eventualmente os machos (TOLEDO, 2005).

Seus fatores de risco estão relacionados a compra de animais sem certificados de sanidade, ausência de vacinação, tamanho do rebanho, densidade da população, idade, sexo, e condições reprodutivas.

\subsection{Patogenia}

Para ARÉSTEGUI et al., (2001); NIELSEN et al., (2004); XAVIER et al., (2009) a patogenicidade da Brucella está relacionada com os mecanismos que permitem sua invasão e multiplicação nas células do hospedeiro, tais como epiteliais e fagocitárias, protegendo-as da ação do sistema imune, onde a porta de entrada principal em bovinos é a mucosa orofaringeana. Sabe-se que bezerros podem eliminar, transitoriamente, 0 agente pela excreção das fezes por até 6 semanas (BEER, 1988).

Os órgãos de predileção da Brucella são os que oferecem elementos para seu metabolismo, como o presente no útero gravídico, e tecidos mamários; isto se deve à produção do hormônio chamado eritritol, que atrai as brucelas e funciona como fator estimulante para o crescimento (CARTER \& CHENGAPPA, (1991); RIBEIRO et al., (2008); XAVIER et al., (2009); TOLEDO, 2005).

A concentração do eritritol eleva-se por volta do 5 mês gestacional, atingindo níveis máximos, e estimulando a multiplicação. Em fêmeas, deixa de ser latente habitualmente quando o tecido córion-alantoideano está bem desenvolvido. A multiplicação da brucella é abundante e as endotoxinas liberadas, levando ao processo inflamatório, causando placentite necrótica dos cotilédones, resultando no descolamento pela lise das suas vilosidades (PAULIN, 2003). Independentemente da porta de entrada, o gênero brucella induz resposta inflamatória entre o período de 6-8 dias pós infecção (MEGID, 2016). "Porém, de acordo com CORRÊA \& CORRÊA (1992), nem todos os órgãos e tecidos invadidos por microrganismos do gênero Brucella apresentam alterações evidentes e áreas de necrose". 
É por via hematógena, a infecção uterina; e suas alterações se diversificam de acordo com a intensidade e tempo gestacional; sua afinidade pelos trofoblastos relaciona-se à presença de concentrações de eritritol e progesterona (SILVA et al., 2005).

Devido à imunidade do animal após o primeiro aborto, há menor número e tamanho das lesões nos placentomas nas gestações posteriores. Com isso os abortos, tornam-se mais raros, ocasionando aparecimento de outras moléstias, como retenção de placenta, natimortos, recém-nascidos fracos, metrite ou endometrite e seguido de subfertilidade, infertilidade ou esterilidade (LAGE et al., 2008; RIBEIRO et al., 2008; XAVIER et al., 2009).

Tal como (GORVEL \& MORENO, 2002; PAULIN \& FERREIRA NETO, 2003; LAGE et al., 2008; NOZAKI, 2008) acrescentam, os bovinos machos que possuem a a B. aborttus, geralmente apresentam progressão no volume dos testículos, epidídimos, vesículas e ampolas de forma uni ou bilateral, podendo se direcionar à atrofia do órgão, levando a subfertilidade, infertilidade ou esterilidade.

\subsection{Sinais Clínicos}

Os sinais clínicos predominantes em vacas gestantes são o abortamento ou o nascimento de animais mortos ou fracos. Geralmente o aborto ocorre na segunda metade de gestação, causando retenção de placenta, metrite e, ocasionalmente, esterilidade permanente. Os animais infectados antes da fecundação seguidamente não apresentam sinais clínicos e podem não abortar. Após um ou dois abortos algumas vacas podem não apresentar sinais clínicos, mas continuam a excretar as brucelas contaminando o meio ambiente. Elas são a origem da infecção para as novilhas (RIBEIRO, 2000).

Nos touros, a infecção se localiza nos testículos, vesículas seminais e na próstata. A doença manifesta-se por orquite, que acarreta baixa de libido e infertilidade. Os testículos podem apresentar degeneração, aderência e fibrose. Às vezes, podem ser observados higromas, sinovites, artrites e queda na produção do leite (RADOSTITS et al., 2002).

Os achados clínicos, incluem: depressão; perda de peso; palidez; dor abdominal; evidências hemorrágicas; linfoadenopatia; esplenomegalia; dispneia; edema de córnea; 
dor meníngea e paresia; hepatomegalia; rigidez e edema, além de dores em articulações (NELSON \& COUTO, 1992).

\subsection{Achados Anatomopatológicos}

De acordo com o trabalho de BANDEIRA, (2011), os achados anatomopatológicos dependem do estado imune do rebanho, mas retenção de placenta e metrite são comuns em casos de abortamento. No touro, ocasionalmente, pode ocorrer orquite e a epididimite em uma ou ambas as bolsas escrotais, onde o acúmulo de líquidos permanece por um tempo, em que podem os testículos passar por processo de necrose de liquefação e serem eventualmente destruídos.

Caso seja efetuada a necropsia, é necessário uso de equipamento de proteção individual e descontaminar todos os materiais utilizados, porém esta atividade não é recomendada por se tratar de uma enfermidade de caráter zoonótico (BRASIL, 2006).

\subsection{Diagnóstico}

A infecção causada pela B. abortus pode ser constatada, por meio de diagnóstico bacteriológico, sorológico e molecular, embora um diagnóstico definitivo e incontestável de brucelose seja um procedimento, demorado que exige recursos laboratoriais nem sempre disponíveis (MATHIAS, MEIRELLES, BUCHALA, 2007). O diagnóstico direto é o isolamento que busca o agente da infecção, e o indireto é o que efetua o aparecimento dos anticorpos.

Os testes descritos estão sendo relatados conforme consta a sua realização no Manual do Programa Nacional de Controle e Erradicação de Brucelose e Tuberculose Animal- PNCEBT, criado pelo Ministério da Agricultura Pecuária e Abastecimento (MAPA) em 2001 (BRASIL, 2006).

Os exames diretos como o PCR, podem ser realizados por meio de Imunofluorescência (visualização de antígenos nos tecidos) ou Imunoistoquímica (localizar antígenos em tecidos). O diagnóstico pode interferir desempenhos, sensibilidade e especificidade, salientando as reações inespecíficas por serem atribuídas a anticorpos naturais que compartilham antígenos estruturais semelhantes às da Brucella. A maioria dos testes, que utilizam suspensão de bactérias como o de soroaglutinação lento (SAL); o teste do Antígeno Acidificado Tamponado (AAT) e o teste de Fixação do Complemento (FC); a maioria dos testes de ELISA e o Teste do Anel em 
Leite (TAL), sendo indiretos, que foram para detectar anticorpos contra a cadeia (GOMES, 2013).

\subsubsection{Teste do Antígeno Acidificado Tamponado (AAT)}

Conhecido como teste de triagem do rebanho, preparado com o antígeno na concentração de $8 \%$, tamponado em pH ácido $(3,65)$ e corado com o Rosa de Bengala. A maioria dos animais positivos, apresenta reação a essa prova, sendo este o teste oficial do programa. Com base na modificação da aglutinação em placa, onde é corado pelo Rosa de Bengala e tamponado a um pH de 3,65. No caso de possuir anticorpos específicos da B.aborttus, desenvolve-se uma reação de aglutinação notório a olho nu (GOMES, 2013).

Existe dificuldade na diferenciação das reações causadas por cepas selvagens, a vacinação de novilhas e animais adultos pode ocasionar em confusão na interpretação de testes, sendo primordial o registro de vacinações e de datas de nascimento para correta interpretação dos resultados dos testes (GOMES, 2013).

O teste de SAL é muito útil para indicar níveis de anticorpos, o teste do 2Mercaptoetanol (2ME) é usado em paralelo com a prova lenta e empregado, e o ELISA foi substituto do AAT por estar padronizado (GOMES, 2013).

\subsubsection{Teste do Anel no Leite}

É realizado para ser aplicado em misturas de leite, uma vez que a baixa concentração do antígeno o torne sensível ou pouco sensível. Empregam-se antígenos corados com hematoxilina, que dá a cor azul à reação positiva e branca à negativa. Se existirem anticorpos no leite, eles se combinarão com as B. abortus (GOMES, 2013).

\subsubsection{Teste do 2-Mercaptoetanol (2-ME)}

Segundo Gomes, (2013), este teste é uma prova quantitativa que detecta a presença de IgG no soro, que é a imunoglobulina indicativa de infecção crônica. Deve ser realizada sempre em paralelo com a SAL; a interpretação dos resultados é dada pela diferença entre os títulos dos soros sem tratamento (SAL), frente ao soro tratado com 2-ME, sendo este também reconhecido pelo Programa Nacional de Controle e Erradicação da Brucelose e Tuberculose Animal- PNCEBT. 


\subsubsection{Teste de Soroaglutinação Lenta (SAL)}

Também conhecida como soroaglutinação em tubos (SAT) é o método lento, porque a leitura dos resultados é feita em 48 horas. Sendo a prova mais antiga, porém, ainda usada, principalmente em associação com o teste do $2 \mathrm{ME}$ em provas de rotina.

Este teste identifica à alta proporção de infectados, porém, pode apresentar falso-negativos, no caso de infeç̧ão crônica e, podem aparecer títulos em não infectados, como decorrência de reações cruzadas com outras bactérias (GOMES, 2013).

\subsubsection{Reação de Fixação de Complemento (RFC)}

Empregado em diversos países que erradicaram ou estão em processo de eliminação da brucelose. É o teste de referência, indicado pela OIE- Organização Mundial de Saúde Animal para o trânsito internacional de animais.

Animais infectados continuam positivos por períodos mais longos, e os vacinados acima de 8 meses de idade, faz com que os anticorpos fixados desaparecem mais rapidamente do que os aglutinantes. (GOMES, 2013).

É um teste complexo e trabalhoso, que exige treinamento pessoal específico e ferramentas atualizadas no laboratório.

\subsection{Diagnóstico Diferencial}

Em razão da variedade de sinais clínicos, nas fases aguda e crônica, são muitas às enfermidades com sintomatologia similares. dentre elas: babesiose, leptospirose, anemia hemolítica autoimune e neoplasias (mieloma, linfoma e leucemia), que devem ser consideradas no diagnóstico diferencial (MEGID et al.; 2016).

\subsection{Medidas de Controle e Prevenção}

Em 2001, foi implantado no Brasil, o PNCEBT - Programa Nacional de Controle e Erradicação da Brucelose e Tuberculose Animal, que visa erradicar a prevalências destas enfermidades (MAPA, 2017). Tem-se por estratégias à redução do número de focos, controle do trânsito de animais reprodutivos e certificação de propriedades livres, e sacrifício dos positivos (PAULIN \& FERREIRA NETO, 2003).

A vacinação é utilizada afim de reduzir a prevalência; dentre as vacinas vivas utilizadas, a B19 se destaca em diversos países, inclusive no Brasil (BRASIL, 2006; RIBEIRO et al., 2008). 
NICOLETTI (1980); PAULIN \& FERREIRA NETO (2003); BRASIL (2006), afirmaram que as características da vacina B19 são desenvolver permissão de aplicação nas fêmeas entre três e oito meses de idade, imunidade prolongada, prevenção de aborto, estabilidade, e não multiplicação com eritritol; além de ser atenuada, o que causa reações mínimas, além de conferir proteção em 70-80\% dos animais

Os animais já vacinados, deverão ser marcados para diferenciação dos demais, esta marca é seguida de um $V$, e emitido atestado de vacinação, ressaltando que a confirmação de animais infectados é tão necessária o sacrifício quanto a proibição da vacina viva em maiores de 8 meses; quanto a idade exigida deve ser seguida rigorosamente, pois se relaciona com a resistência dos anticorpos (MEGID et al., 2016).

A vacina B19 deve ser aplicada somente em fêmeas com até oito meses de idade, todavia que após este período há chances de grande produção de anticorpos que podem perdurar e interferir no resultado; não se recomenda protocolo de machos ou fêmeas em gestação, devido à virulência residual conservada, levando machos a permanecerem com títulos por longos períodos, não necessidade de descarte além da possibilidade de orquite e artrites, entretanto em fêmeas prenhes, pode provocar aborto, geralmente no terço final da gestação (BIOSFERA, 2014, MEGID, 2016; RIBEIRO, 2000).

De acordo com os relatos de POESTER et al., (2005); GARCÍA-YOLDI et al., (2006); AMAKU et al., (2009), houve necessidades de amostra vacinal que não provocasse indução de anticorpos, com isso foi desenvolvida a RB51, em meios de cultura rifampicina de origem rugosa, prevenindo formação de anticorpos reagentes, não interferindo no diagnóstico, e diminuindo assim sua virulência.

Nos últimos tempos, a vacina não indutora de anticorpos aglutinantes (amostra RB51) vem sendo a vacina oficial do programa de controle de brucelose dos EUA, do México e do Chile (BRASIL, 2006). A diferença entre elas é que a vacina cepa B19, se faz obrigatória para fêmeas de 3 a 8 meses, já a RB51 permite vacinação em idade acima de 8 meses.

Além das estratégias do PNCEBT, temos que nos preocupar com a introdução de animais infectados nas propriedades e rebanhos. O correto é que esses animais procedam de rebanhos livres, ou que sejam submetidos à testes rotinais que lhes coloca em condição de não infectados (BRASIL, 2006). Os doentes deverão ser marcados com um " $P$ ", no lado direito da cara, dentro do prazo de 30 dias, a contar da realização dos 
testes, e deverão ser encaminhados ao abate, sob orientação do serviço oficial de defesa sanitária animal (BRASIL, 2006).

\subsection{Impactos em Saúde Pública}

O isolamento da Brucella nos seres humanos reflete a sua presença na população animal (SOLA et al.; 2014). Em humanos, nos últimos 15 anos tem evoluído exorbitantemente, por funções socioeconômicas, e sistemas de vigilância aprimorados (PAPPAS et al.; 2006). O gênero pode ser destruído através da pasteurização, sabe-se também que esta bactéria pode permanecer por semanas em sorvetes e meses na manteiga quando congelada tal enfermidade consegue se manter intacta por anos (MEGID, 2016).

Ingestão de alimentos contaminados, mucosa e pele lesadas são situações de relacionados à infecção, além dos acidentes de percurso como perfuração no ato da vacinação, mesmo sabendo-se ser rara (MEGID, 2016), podendo acometer também funcionários que mantém ligação ao abate e que estão expostos ao sangue, carcaças e vísceras.

É considerada subdiagnosticada, pois os sinais podem ser confundidos, se os procedimentos de isolamento não são rotineiramente aplicados, geralmente é confundida com gripe, sendo diagnosticadas fadiga, cefaleia, dores musculares e sudorese. Algumas das complicações mais são tromboflebite, espondilite e artrite periférica (SILVA et al., 2005; AL DAHOUK et al., 2007).

A infecção pode acometer quase todos os órgãos e apresentar consequências. Em humanos, a sintomatologia febril deve ser averiguada para eliminar possibilidade de brucelose, principalmente se o paciente for de área rural ou tiver contato com animais frequentemente (SILVA JUNIOR (2008).

\section{CONSIDERAÇÕES FINAIS}

A brucelose é uma doença infecciosa, causada por bactérias do gênero Brucella spp., que acomete várias espécies de animais, entre domésticos e silvestres, além do homem. Enfermidade esta, que possui impacto na saúde pública e na economia, sendo capaz de gerar problemas no comércio internacional, principalmente quando 
relacionada ao sistema reprodutivo como: abortos, e baixa fertilidade nas propriedades rurais.

Encontra-se mundialmente distribuída e caracterizada com endêmica no Brasil. Os abortos acontecem frequentemente e na maioria das vezes, podem ser acompanhados de retenção de placenta, metrite, repetição de cios, diminuição do número de partos e maior intervalo.

No homem, pode ser caracterizada como ocupacional, visto que os indivíduos mais expostos são os que trabalham diretamente com os animais infectados (tratadores, proprietários, veterinários) ou manipulam produtos de origem animal (magarefes, laboratoristas).

É característica de animais sexualmente maduros e tem como principal sintoma o aborto com retenção de placenta, que ocorre após o sexto mês de gestação. A placenta geralmente apresenta necrose e aderência dos cotilédones às carúnculas maternas. Podendo o feto se apresentar de madeira edematosa, com presença de líquido sero-sanguinolento nas cavidades torácica e abdominal, seguido de uma broncopneumonia na maioria dos casos. Já nos machos, os principais problemas ocasionados, diante desta enfermidade são orquite (inflamação dos testículos) e/ou epididimite (inflamação do epidídimo).

O Programa Nacional de Controle e Erradicação da Brucelose e da Tuberculose Animal (PNCEBT) instituído pelo Ministério da Agricultura, Pecuária e Abastecimento (MAPA) busca uma redução na prevalência e na incidência da brucelose e tuberculose, através da vacinação obrigatória de fêmeas, com idade entre três a oito meses, contra a brucelose e a certificação de propriedades livres ou monitoradas para as doenças, trazendo assim, benefícios sanitários e econômicos, diminuindo o impacto negativo dessas zoonoses na saúde humana e animal, além de promover a competitividade da pecuária nacional.

\section{REFERÊNCIAS}

AL DAHOUK, S.; LE FLECHE, P.; NOCKLER,K.; JACQUES, I.; M. GRAYON, M.; SCHOLZ, H. C.; TOMASO, H.; VERGNAUD, G.; NEUBAUER, H. Evaluation of Brucella MLVA typing for human brucellosis, Journal of Microbiological Methods, Amsterdam, [online], v. 69, p.137-145, 2007. Disponível em: http://www.ncbi.nlm.nih.gov/pubmed/17261338. 
ARÉSTEGUI, M. B.; GUALTIERI, S. C.; DOMÍNGUEZ, J.; SCHAROVSKY, O. G. El género Brucella y su interacción con el sistema mononuclear fagocítico. Veterinaria México, Mexico, [online], v. 32, n. 2, p. 131-139, abr-jun. 2001. Disponível em: http://www.medigraphic.com/pdfs/vetmex/vm-2001/vm012f.pdf.

BEER, J. Doenças Infecciosas em Animais Domésticos. São Paulo: Livraria Roca Ltda,1988, 380p.

BRASIL. Decreto n. 30.691, de 29 de março de 1952. Regulamento da Inspeção Industrial e Sanitária de Produtos de Origem Animal. Diário Oficial da União, Brasília, seção I, p. 10785, 07 jul. 1952. Disponível em: http://extranet. agricultura.gov.br/sislegis/action/detalhaAto.do?method=consultarLegislacaoF ederal.

BRASIL. Ministério da Agricultura e Abastecimento. Boletim de defesa sanitária animal, Brasília: MAPA, v. 30, n. 53-57, 2001.

BRASIL. Ministério da Agricultura, Pecuária e Abastecimento. Programa Nacional de Controle e Erradicação da Brucelose e da Tuberculose Animal (PNCEBT). Brasília: MAPA/SDA/DSA, 2006. 188 p. Disponível em: http://www.agricultura.gov.br/pls/portal/url/ITEM/3D2720AF1EOFD67FE040A8 C0750 2246C.

BRASIL. Ministério da Saúde. Portaria no 104 de 25 de janeiro de 2011. Define as terminologias adotadas em legislação nacional, conforme o disposto no Regulamento Sanitário Internacional 2005 (RSI 2005), A relação de doenças, agravos e eventos em saúde pública de notificação compulsória em todo o território nacional e estabelece fluxo, critérios, responsabilidades e atribuições aos profissionais e serviços de saúde. Brasília, 2011.

BRASIL. Ministério de Agricultura, Pecuária e Abastecimento. Programa Nacional de Controle e Erradicação da Brucelose e da Tuberculose Animal (PNCEBT): Manual técnico. Brasília, 2006. 184p.

BRASIL. Secretaria Nacional de Defesa Agropecuária. Secretaria de Defesa Sanitária Animal. AS doenças dos animais no Brasil: histórico das primeiras observações. Brasília: SNAP/SDSA, 1988. 101p. (Boletim de defesa sanitária animal, número especial.

BRUCELOSE BOVINA: REVISÃO. ENCICLOPÉDIA BIOSFERA, Centro Científico Conhecer Systematic and Evolutionary Microbiology, Reading, [online], v. 57, p. 26882693, 2007. Disponível em: http://ijs.sgmjournals.org/cgi/reprint/57/11/2688.

CAPASSO, L. Bacteria in two-millennia-old cheese, and related epizoonoses in Roman populations. J. Infect., v.45, p.122-127, 2002. 
CARDOSO, S. C. T.; COSTA, L. M. C. A BRUCELOSE NO BRASIL SOB O ENFOQUE DA SAÚDE PÚBLICA- artigo disponível em Faculdade de Agronomia e Medicina Veterinária da Universidade de Brasília - UnB. Erradicação de Brucelose e Tuberculose. Arq. Bras. Med. Vet.

CARTER, G. R.; CHENGAPPA, M. M. Essentials of veterinary bacteriology and mycology. 4. ed. Philadelphia: Lea and Febiger, 1991. p. 196-201.

COSTA, M. Brucelose bovina e eqüina. In: RIET-CORREA F. et al. (Ed.). Doenças de ruminantes e eqüinos. 2.ed. São Paulo : Varela, 2001. V.1, p.187-197.

FERREIRA, A. de M.; Sá, W. F.; VIANA, J. H. M.; CAMARGO, L. S. A. Brucelose- EMBRAPA, Agência de informação EMBRAPA, agronegócio do Leite. Ministério da Agricultura Pecuária e Abastecimento; 2017.

FONTES, C. A. M.; VALENTE, L. C.; PEREIRA, M. L. C.; MOTA, M. A.; SILVA, V. Y. FOSTER, G.; OSTERMAN, B. S.; GODFROID, J.; JACQUES, I.; CLOECKAERT, A. Brucella ceti sp. nov. and Brucella pinnipedialis sp. nov. for Brucella strains with cetaceans and seals as their preferred hosts. International Journal of

FOSTER, G.; OSTERMAN, B. S.; GODFROID, J.; JACQUES, I.; CLOECKAERT, A. Brucella ceti sp. nov. and Brucella pinnipedialis sp. nov. for Brucella strains with cetaceans and seals as their preferred hosts. International Journal of Systematic and Evolutionary Microbiology, Reading, [online], v. 57, p. 2688-2693, 2007. Disponível em: http://ijs.sgmjournals.org/cgi/reprint/ 57/11/2688.

GALINDO, A. S. D.; Programa Nacional de Controle e Erradicação da Brucelose e da Tuberculose Animal - PNCEBT- Ministério da Agricultura, pecuária e abastecimento. Género Brucella y su interacción con el Sistema Mononuclear Fagocítico. Veterinaria México, Mexico, [online], v. 32, n. 2, p. 131-139, abr-jun. 2001. Disponível em: Goiânia, v.10, n.18; 2014.

GOMES, M. JP. Gênero Brucella spp- FAVET-UFRGS- 2013.

GOMES, R. C.; FEIJÓ, G. L. D.; CHIARI, L. Evolução e Qualidade da Pecuária Brasileira. Campo Grande: EMBRAPA gado de corte, 2017.

GORVEL, J. P.; MORENO, E. Brucella intracellular life: from invasion to intracellular replication. Veterinary Microbiology, Amsterdam, [online], v. 90, n. 1-4, p. 281297, dez. 2002. Disponível em: http://www.ncbi.nlm.nih.gov/pubmed/ 12414149.Guanabara Koogan, 1991. 1082 p.

Leandro J, Roberto $\mathrm{H}$, Antunes $\mathrm{M}$ - Brucella endocarditis of the aortic valve. Eur J Cardiothorac Surg, 1998;13:95-97 p. 
MAPA; Programa Nacional de Controle e Erradicação da Brucelose e da Tuberculose Animal - PNCEBT; publicado 05/01/2017 14h34, última modificação 08/11/2017 $12 \mathrm{~h} 50$

MATHIAS L.A., ALBERTO L.H., ROXO E., PERECIN D. \& GIRIO R.J.S. 1991. Avaliação de uma microtécnica de fixação de complemento no diagnóstico sorológico.

MATHIAS, L. A.; MEIRELLES, R. B.; BUCHALA, F. G. Estabilidade do antígeno de célula total de Brucella abortus para uso no diagnóstico sorológico da brucelose bovina pela reação de fixação de complemento. Pesquisa Veterinária Brasileira., v. 27, n. 1, p. 18-22, 2007.

MEGID, J.; MATHIAS, L. A. Doenças infeciosas em animais de produção e de companhia/ Jane Megid, Marcio Garcia Ribeiro, Antônio Carlos Paes- Ed- Rio de Janeiro: Roca, 2016. 1294 p.; pg 21.

MERIAL. Brucelose, site coorporativo- 2017.

N. E. DA. KASHIWABARA, T. G. B. BRUCELOSE: UMA REVISÃO DE LITERATURA- Brazilian Journal of Surgery and Clinical Research - BJSCR- Vol.6,n.3,pp.53-56 (Mar - Mai 2014

NEGREIROS, R.L.; DIAS R. A.; FERREIRA F.; NETO F. J.S.;; GONÇALVES2

NICOLETTI, P. the epidemiology of bovine brucellosis. Advances in Veterinary Sciences and Comparative Medicine, v.24, 69-98, 1980.

NICOLETTI, P.; MURASCHI, T. F. Bacteriologic evaluation of serologic test procedures for the diagnosis of brucellosis in problem cattle herds. American Journal of Veterinary Research, v27, p 689-694, 1966.

NETA, A. V. C.; MOL, J. P. S.; XAVIER, M. N.; PAIXAO, T. A.; LAGE, A. P.; SANTOS, R. L. Pathogenesis of bovine brucellosis. The Veterinary Journal, London, [online], $\mathrm{v}$. 184, n. 2; p. 146-155, sep. 2009. Disponível em: http://www.ncbi. nlm.nih.gov/pubmed/19733101.

NICOLETTI, P. A short history of brucellosis. Veterinary Microbiology, Amsterdam, [online], v.90, n.1-4, p.5-9, dez. 2002. Disponível em: http://www.ncbi.nlm.nih.gov/pubmed/12414128.

NICOLETTI, P. The epidemiology of bovine brucellosis. Advances in veterinary science comparative medicine, New York , v. 24, p.69-98, 1980.

NIELSEN, K.; SMITH, P.; WIDDISON, J.; GALL, D.; KELLY, L.; NICOLETTI, P. Serological relationship between cattle exposed to Brucella abortus, Yersinia enterocolitica 0:9 and Escherichia coli 0157:H7. Veterinary Microbiology, Amsterdam, [online], v. 100, n. 1-2, p. 25-30, mai. 2004. Disponível em: http://www.ncbi.nlm.nih.gov/pubmed/15135510. 
NOZAKI, C.N. Aspectos epidemiológicos, clínicos e avaliação de métodos diagnósticos nas fases da evolução da brucelose em ovinos inoculados experimentalmente com Brucella ovis [online]. 2008. 109 p.

OIE. ORGANIZAÇÃO MUNDIAL DE SAÚDE ANIMAL. Bovine brucellosis. Terrestrial Animal Health Code. 2013. Chapter 11.3. Disponível em: http://www.oie.int/fileadmin/Home/eng/Health_standards/tahc/2009/en_cha pitre_1.11.3.htm.

OLIVEIRA, J. P. Estudo das lesões sugestivas de brucelose em bovinos e bubalinos abatidos para consumo. 2003. 53 f. Dissertação (Mestrado em Ciência Animal)Universidade Federal do Pará.

PAPPAS, Georgios et al.The new global map of human brucellosis. The Lancet Infectious Diseases, v. 6, i. 2, p. 91-99, fev. 2006. Disponível em 10 de junho de 2011.

PAPPAS G , PAPADIMITRIOU P , AKRITIDIS N , CHRISTOU L , TSIANOS EV-O novo mapa global da brucelose humana. Lancet Infect Dis. 2006 fev; 6 (2): 91-9.

PAULIN L. M.; FERREIRA NETO J. S. O Combate à Brucelose Bovina: situação brasileira. Jaboticabal: Funep, 2003. 154p.

PAULIN, L. M. S.; FERREIRA NETO, J. S. Brucelose em búfalos. Arquivos do Instituto Biológico, São Paulo, [online], v. 75, n. 3, p. 389-401, jul./set., 2008. Disponível em: http://www.biologico.sp.gov.br/docs/arq/v75_3/paulin.pdf.

PESSEGUEIRO, P.; BARATA, C.; CORREIA J. Brucelose - uma revisão sistematizada. Unidade de Hemodiálise, Hospital do Espírito Santo, Évora Recebido para publicação a 31/01/2002; Medicina Interna Vol. 10, N. 2, 2003.

PESSEGUEIRO, P.; BARATA, C.; CORREIA, J. Medicina Interna, Lisboa, [online], v. 10, n. 2, p. 91-100, 2003. Disponível em: http://www.spmi.pt/revista/ vol10/vol10- n2brucelose.pdf.

POESTER, F.; FIGUEIREDO V.C.F.; LÔBO J.R.; GONÇALVES V.S.P.; LAGE, A.P.; ROXO, E.; MOTA, P.M.P.C.; MÜLLER, E.E.; NETO, J.S. F. Estudos de prevalência da brucelose bovina no âmbito do Programa Nacional de Controle e Erradicação da Brucelose e Tuberculose Animal.

POLETTO, R.; KREUTZ, L. C.; GONZALES, J. C.; BARCELLOS, L. J. G. Prevalência de tuberculose, brucelose e infecções víricas em bovinos leiteiros do município de Passo Fundo, RS, Ciência Rural, v. 34, n. 2 (2004). Publicado 05/01/2017 última modificação 08/11/2017

PROBERT, W.S.; SCHRADER, K. N.; KHUONG, N. Y.; BYSTROM, S. L.; GRAVES, M. H. Realtime multiplex PCR assay for detection of Brucella spp., B. abortus, and B. 
melitensis. Journal of clinical microbiology, Washington, [online], v. 42, n. 3, p. 1290-1293, mar. 2004. Disponível em: http://www.ncbi. nlm.nih.gov/pubmed/15004098.

RADOSTITS, O. M.; GAY, C. C.; HINCHCLIFF, K. W.; CONSTABLE, P. D. Veterinary medicine. A textbook of the diseases of cattle, horses, sheep, pigs, and goats. 10. ed. Philadelphia: Saunders, 2007. p.963-994.

REDVET Rev. Electrón. vet. http://www.veterinaria.org/revistas/redvet 2017 Volumen 18 № 9. MAPA/SDA/DAS, $2006 . \quad 188 p$.

RIBEIRO, M.G.; NARDI JÚNIOR, G.; MEGID, J.; PAES, A. C.; LISTONI, F. J. P. Aglutininas anti-Brucella abortus no soro e em secreção de bursite cervical em equinos. Arquivo Brasileiro de Medicina Veterinária e Zootecnia, Belo Horizonte, v. 55, n. 1, fev. 2003. Disponível em: http://www.scielo.br/scielo. php?pid=S010209352003000100015\&script=sci_arttext.

RIBEIRO, Vincente da Fonseca, CONTROLE E ERRADICAÇÃO DA BRUCELOSE BOVINA,UNIVERSIDADE DO ESTADO DE SANTA CATARINA, Pag 13,14, ano 2000.

ROTH, F., ZINSSTAG, J., ORKHON, D., OCHIR, C., HUTTON, G., COSIVI, G. C., OTTE, J. Human health benefits from livestock vaccination for brucellosis: case study. Bulletin of the World Health Organization, v. 81, n. 12, p. 867-876, 2003.

SCHOLZ, H. C.; HUBALEK, Z.; SEDLÁČEK, I.; VERGNAUD, G; TOMASO, H;, AL DAHOUK, S.; MELZER, F.; KÄMPFER, P.; NEUBAUER, H.; CLOECKAERT A.; MAQUART, M.; ZYGMUNT, M. S.; WHATMORE, A. M.; FALSEN, E.; BAHN P.; GÖLLNER, C.; PFEFFER, M.; HUBER, B.; BUSSE, H. J.; NÖCKLER, K. Brucella microti sp. nov., isolated from the common vole Microtus arvalis. International Journal of Systematic and Evolutionary Microbiology, Reading, [online], v. 58, p. 375-382, 2008. Disponível em: http://ijs.sgmjournals.org/cgi/content/ abstract/58/2/375.

SCHMITT, C. I.; KRUG, F. D. M.; CERESER, N. D.; PINTO, F. de R. Brucelose: uma questão de saúde pública - REDVET - Revista electrónica de Veterinaria.

SCHOLZ, H. C.; NÖCKLER, K.; GÖLLNER, C.; BAHN, P.; VERGNAUD, G.; TOMASO, H.; AL DAHOUK, S.; KÄMPFER, P.; CLOECKAERT, A.; MAQUART, M.; ZYGMUNT, M. S.; WHATMORE, A. M.; PFEFFER, M.; HUBER, B.; BUSSE, H. J.; DE, B. K. Brucella inopinata sp. nov., isolated from a breast implant infection. International Journal of Systematic and Evolutionary Microbiology, Reading, [online], v. 60, n. 4, p. 801-808, abri. 2010. Disponível em: http://www.ncbi.nlm.nih.gov/pubmed/19661515.

SILVA JUNIOR, F. F. Diagnóstico da brucelose bovina em animais de frigoríficos pela sorologia, bacteriologia e PCR. 2008. 64f. Tese. (Doutorado em Saúde Animal, Saúde Pública Veterinária e Segurança Alimentar) - Faculdade de Medicina Veterinária e Zootecnia - Campus Botucatu, Universidade Estadual Paulista, 
Botucatu. Situação epidemiológica da brucelose bovina no Estado de Mato Grosso- Arq.

SOLA, M. C.; FREITAS, F. A.; SENA, E. L. de S.; MESQUITA, A. SOLA, M. C.; FREITAS, F. A.; SENA, E. L. S.; MESQUITA, A, J. BRUCELOSE BOVINA: REVISÃO, ENCICLOPÉDIA BIOSFERA, Centro Científico Conhecer, Goiânia, v. 10, n. 18; p. 2014 686, 2014.

TOCANTINS, S. Distribuição espacial da brucelose no gado bovino no Pantanal de Mato Grosso e relação com fatores ambientais. 2000. Tese de Mestrado, Curso de Biologia (Ecologia).

TOLEDO, K. A; UNIVERSIDADE CASTELO BRANCO, BRUCELOSE BOVINA, ano 2006.

TOLEDO, Marita Pilon, Centro Universitário Anhanguera, Brucelose bovina: Vacinação de bezerras entre 3 e 8 meses de idade no município de Santa Cruz da Conceição, pag. 2, 2005.

UEMURA, E. H. LABORCLIN, produtos para laboratórios Ltda. ANTÍGENO ROSA BENGALA- LB 171004 - Rev. 03 - 09/03.

V.S.P.; Silva, M.C.P., FIGUEIREDO, V.C.F., LÔBO, J.R.; FREITAS J.; AMAKU M. VERONESI, R. Doenças Infecciosas e Parasitárias. 8a ed., Rio de janeiro: Zootec. vol.61 supl.1 Belo Horizonte nov. 2009. 


\section{CAPÍtULO IV}

\section{CARBÚNCULO SINTOMÁTICO - DISCUSSÕES CLÍNICO- EPIDEMIOLÓGICAS}

DDI: 10.51859/amplla.pdi443.1121-4

Gustavo Santana Ribeiro de Oliveira ${ }^{1}$ José Tiago das Neves Neto ${ }^{2}$ Ísis Assis Braga ${ }^{2}$

Eric Mateus Nascimento de Paula ${ }^{2}$

${ }^{1}$ Médico Veterinário Autônomo. Egresso do Curso de Medicina Veterinária do Centro Universitário de Mineiros UNIFIMES

${ }^{2}$ Docente do Curso de Medicina Veterinária do Centro Universitário de Mineiros - UNIFIMES.

\section{RESUMO}

O Clostridium chauvoei é uma bactéria Gram positiva, anaeróbia e se apresenta em formato de bacilo. Causa a doença conhecida como carbúnculo sintomático ou manqueira e acomete principalmente animais jovens da espécie bovina, podendo ocorrer também em ovinos e caprinos. A doença pode causar um grande prejuízo econômico por ser de difícil tratamento, podendo levar o animal a óbito em questão de horas, pelo motivo de ser uma enfermidade de caráter agudo. A bactéria pode contaminar bebedouros, pastagens, solos e currais. Pelo fato de ser uma doença popularmente conhecida, sua patogenia ainda é incerta, sabendo apenas que os animais se infectam por via oral, ingerindo a forma esporulada da clostridium chauvoei e eliminando a mesma através das fezes. Podendo ser diagnosticada através dos métodos de imunofluorescência direta, isolamento bacteriano e PCR (Reação em Cadeia da Polimerase). $O$ tratamento se baseia no uso de penicilina em altas doses, administrando por via I.M (intramuscular) ou I.V (intravenoso). A vacinação dos animais é uma das principais medidas profiláticas contra o carbúnculo sintomático, mas o manejo de pastagens, currais e dos próprios animais se faz necessário no controle da enfermidade.

Palavras-chave: Bovino. Clostridium chauvoei. Manqueira. Vacinação.

\section{INTRODUÇÃO}

Desde o século XV, a bovinocultura se faz presente no histórico e no desenvolvimento do Brasil. Ao longo dos anos, se destaca como uma das principais atividades econômicas da agropecuária brasileira. Estima-se que os rebanhos ocupam 
uma área de aproximadamente $20 \%$ de todo território brasileiro, sendo cerca de 200 milhões de cabeças de gado (ANDRADE et al., 2015).

Dentre todos os fatores para a obtenção do sucesso na criação de gado, a sanidade é um fator de extrema importância. Um manejo adequado dos animais, dos locais onde transitam como, currais, pastagens, fômites, entre outros; pode evitar o aparecimento de doenças que interferem na produtividade do rebanho. E juntamente, é claro, com a inclusão de um calendário profilático de vacinação (PEREIRA, 2014).

No Brasil, as doenças causadas por clostrídios são as que mais acometem os animais domésticos, provocando grandes prejuízos econômicos (LOBATO et al., 2013). Bactérias do gênero Clostridium são anaeróbicas, Gram positivas e possuem um formato de bacilo e atingem uma forma resistente chamado esporo, os quais podem contaminar solos por um longo tempo causando riscos aos animais e humanos (LOBATO et al., 2013).

O carbúnculo sintomático trata-se de uma enfermidade aguda, que acomete bovinos e ovinos, causada pelo Clostridium chauvoei, sendo que em bovinos a doença ocorre na forma endógena, mais comum em animais jovens. A via de transmissão se dá pela ingestão de esporos que são eliminados pelas fezes de animais infectado. Apesar de não ser bem esclarecida a forma com que os esporos migram para o tecido musculares, acredita-se que o principal responsável por essa distribuição seja os macrófagos (LOBATO et al., 2013).

$\mathrm{O}$ respectivo trabalho tem por objetivo, esclarecer a forma de contágio e transmissão do clostridium chauvoei, por meio de uma revisão bibliográfica, assim como também o entendimento da patogenia da doença, seu tratamento, diagnóstico e medidas de controle.

\section{REVISÃO DE LITERATURA}

\subsection{Definição}

O carbúnculo sintomático é uma clostridiose de caráter agudo, não contagiosa. Sua etiologia está relacionada ao Clostridium chauvoei, que é responsável pelo desenvolvimento de uma lesão efisematosa, podendo acometer ruminantes de forma geral. Comumente afeta animais jovens, que clinicamente apresentam formações gasosas de edema na musculatura (MEGID et al., 2016). Existem dois tipos de 
apresentações clínicas do carbúnculo sintomático, a forma clássica que afeta a musculatura dos animais infectados e a visceral, que tem como principal alvo o coração. No Brasil não se tem relatos da forma visceral (ASSIS et al., 2005).

É uma doença considerada endógena para bovinos e exógena para ovinos (ASSIS et al., 2010). Popularmente, também pode ser conhecida como manqueira e mal do ano; em países de língua inglesa tem a sinonímia de black leg e black quarter (LOBATO et al., 2007; MEGID et al, 2016).

\subsection{Histórico}

Considerada uma doença fatal para bovinos, ovinos e caprinos, seu primeiro relato foi em 1870 (ARMSTRONG; MCNAMEE, 1950 citado por ALAM et al., 2018), mas somente no ano de 1880 que foi descoberto o seu agente etiológico, C. chauvoei. Dentre as doenças que causam mionecrose, o carbúnculo sintomático foi pouco estudado, não sabendo quase nada sobre os mecanismos de ação das toxinas produzidas (LOBATO et al., 2013). A vacinação contra carbúnculo sintomático existe desde 1930 e mesmo assim casos da doença são relatados anualmente (IDREES et al., 2018).

Cientistas pensavam que o C. chauvoei não tinha importância zoonótica pelo motivo do microrganismo infectar especificamente os ruminantes. Mas no ano de 2008, foi registrado um caso de gangrena gasosa fulminante humana causada pelo C. chauvoei, confirmado através do exame PCR (ALAM et al., 2018).

\subsection{Agente Etiológico}

O C. chauvoei possui o formato de um bastonete reto, sendo o mesmo, pleomórfico, podendo chegar a $8 \mathrm{~nm}$ de comprimento e 0,6 nm de largura. Trata-se de uma bactéria anaeróbica, Gram-positiva e formadora de esporos quando na presença de oxigênio (MEGID et al., 2016). Os esporos são células que se encontram em repouso e possuem grande resistência em condições adversas como, alta temperatura, radiação, agentes químicos, entre outros (STRINGER et al., 2014).

Os antígenos solúveis, conhecidos como toxinas, têm envolvimento no processo patogênico do carbúnculo sintomático, são elas: leucocina hemolítica CctA, hemolisina D, DNase, hialuronidase Nag e neuraminidase/sialidase NanA (ZIECH et al., 2018). Recentemente foi identificada a toxina $\operatorname{CctA}$, sendo a principal causadora do fator de 
virulência do agente. Sendo necessário mais estudos para melhor entender essa e outras toxinas produzidas pelo C. chauvoei (LOBATO et al., 2013).

Em ágar em sangue de ovino (5\%), as colônias possuem um formato esférico, irregulares, compactas e são extremamente delicadas; apresentando ainda hemólise ao redor e tem um odor rançoso (MEGID et al., 2016).

\subsection{Epidemiologia}

\subsubsection{Distribuição Geográfica}

Por estar disseminada entre os ruminantes causando grandes perdas econômicas no sistema de produção animal (FREY \& FALQUET, 2015), o carbúnculo sintomático é uma doença endêmica em países desenvolvidos e em desenvolvimento, muito conhecida pelos prejuízos que causa nos sistemas de criação. Grande parte dos casos ocorre durante os meses quentes, após a escavação do solo e em épocas chuvosas. Em ambientes de inundações, a doença é considerada enzoótica (ZIECH et al., 2018). A enfermidade é bastante frequente em regiões que se tem escavações do solo, por conta dos esporos que contaminam o ambiente (MEGID et al., 2016).

\subsubsection{Cadeia Epidemiológica}

\subsubsection{Fonte de Infecção}

O C. chauvoei habita o trato digestivo dos herbívoros que disseminam a bactéria em forma de esporos no solo (ASSIS et al., 2005). Os esporos bacterianos permanecem viáveis e retém, além da sua vitalidade, seus mecanismos de virulência por longos períodos de tempo (PIRES, 2015).

\subsubsection{Via de Eliminação}

O C. chauvoei é eliminado por meio das fezes e das carcaças que pode contaminar bebedouros, solo, currais e pastagens. As áreas podem permanecer contaminadas durante anos. Se as carcaças de animais que foram infectados pelo clostridium chauvoei não forem descartadas corretamente, as mesmas podem contaminar o solo com os esporos do clostrídio (PIRES, 2015).

\subsubsection{Meio de Transmissão}

A principal via de transmissão é através da ingestão de pasto e água contaminados pelos esporos. Não ocorre transmissão direta (PIRES, 2015). 


\subsubsection{Porta de Entrada}

Bovinos e ovinos se infectam principalmente por via oral, pela ingestão de forragens contaminadas pelos esporos do clostrídio (ASSIS et al., 2005). Especialmente em bovinos jovens, quando ocorre a troca dentária, desenvolve-se mais uma porta de entrada para os esporos (MEGID et al., 2016). Ovinos também são acometidos através da castração, corte de cauda, descorna e tosa (GREGORY et al., 2006).

\subsubsection{Hospedeiros Susceptíveis}

Acomete ruminantes jovens (até 3 anos) de forma geral, sendo os bovinos a principal espécie afetada (GREGORY et al., 2006).

Bovinos de 6 meses a 3 anos de idade são mais susceptíveis por conta da queda de anticorpos colostrais. Em animais mais velho, a enfermidade não é muito frequente por conta da imunidade adquirida naturalmente, mas não o impossibilita de ser infectado. Os ovinos podem se infectar em qualquer faixa etária. A infeç̧ão está relacionada com lesões de procedimentos de rotina, como casqueamento, caudectomia, castração, tosa, descorna e vacinação. Ou seja, qualquer tipo de lesão que leve a infecção por esporos que estão presentes no ambiente (MEGID et al., 2016).

\subsection{Patogenia}

A patogenia do carbúnculo sintomático ainda é incerta. Confirmados apenas infecções de forma natural e através de experimentos (COOPEP; VALENTINE, 2016 citado por HECKLER et al., 2018).

Os animais se infectam durante a alimentação, ingerindo os esporos do clostridium chauvoei. Esporos esses que podem sobreviver durante anos no meio ambiente. Grande parte dos esporos ingeridos são eliminados nas fezes e outra parte chega a ser absorvido a nível de corrente sanguínea. Já na corrente sanguínea, os esporos são transportados pelos macrófagos para o fígado, tecidos capilares, tecido subcutâneo e para a musculatura. Traumas como coices, quedas, perfuração por objetos, vacinas, entre outros, causam uma deficiência circulatória ou necrose do local, favorecendo uma baixa oxigenação, e assim, transformando a forma esporulada da bactéria para a forma vegetativa. Nessa condição de anaerobiose a bactéria se multiplica e inicia a produção das toxinas, agravando e aumentando rapidamente a área lesada (MEGID et al., 2016). 
O clostrídio também pode infectar o animal juntamente com outros tipos de microrganismos, aproveitando de condições de anaerobiose causada por outros agentes e se multiplicar e produzir suas toxinas (GREGORY et al., 2006).

As toxinas produzidas pela forma vegetativa da bactéria, fermentam o glicogênio muscular, produzindo gases, ácido acético e ácido butírico. Também pode ocorrer hemorragia, edema, edema gasoso e necrose nas áreas musculares afetadas. Em ovinos o processo patogênico da doença por continuidade de pele é semelhante ao dos bovinos (MEGID et al., 2016). As musculaturas mais afetadas incluem os da pelve, peitoral, diafragma, língua e miocárdio. Podendo ocorrer também pericardite fibrinohemorrágica e pleurite (BARROS, 2016).

\subsection{Sinais Clínicos}

A forma clássica da enfermidade caracteriza-se por uma evolução hiperaguda, variando seu período de incubação de 1 a 5 dias. Animais infectados apresentam um quadro de febre $\left(41 \mathrm{a} 43^{\circ} \mathrm{C}\right)$. Coxa, região lombar e região da escápula são os locais mais afetados pela doença. Região cervical e cabeça raramente são acometidos (MEGID et al., 2016). Quando a doença não é controlada com rapidez, o animal desenvolve toxemia sistêmica e choque, podendo vir a óbito. Quando a enfermidade se espalha pela musculatura, observa-se dificuldade de locomoção, aumento de volume, crepitação subcutânea devido a produção de gás causada pela bactéria, edema e hemorragia (LOBATO et al., 2013). Após a morte, os animais apresentam posição de cavalete e inchaço por putrefação, podendo haver também hemorragias com presença de muco espumoso. Na fase crônica da doença, necrose dos tecidos subcutâneo e muscular e a presença de fístulas na musculatura acometida são relatados (MEGID et al., 2016).

Já na forma visceral, o carbúnculo pode se apresentar assintomática. Nesse caso, são acometidos língua, diafragma e coração (LOBATO et al, 2013).

\subsection{Diagnóstico}

O diagnóstico de carbúnculo sintomático deve ser feito imediatamente ou logo após a morte do animal, preferencialmente em mais de um animal do rebanho, quando da ocorrência de surtos, sendo a anamnese clínica imprescindível para avaliação da ocorrência de feridas ou não (GROSETH et al., 2011). O diagnóstico é basicamente definido no estudo epidemiológico juntamente com os sinais clínicos. O material 
coletado para diagnóstico em animais vivos é o líquido presente no local da lesão, e em animais mortos, coleta-se músculos afetados e sangue (MEGID et al., 2016). Diagnósticos laboratoriais mais utilizados são o PCR, imunofluorescência direta, isolamento bacteriano e imunoistoquímica (LOBATO et al., 2013). Ao coletar os materiais, certificar que estão bem embalados para não haver deterioração e os enviar o mais rápido possível para o laboratório (GREGORY et al., 2006).

$\mathrm{O}$ isolamento do agente requer um pouco mais de espera, que varia entre 4 a 7 dias para se completar. PCR e imunofluorescência direta são o diagnóstico com mais sensibilidade e os mais importantes, por isso são os de primeira escolha (ASSIS et al., 2005).

\subsubsection{Exame Clínico}

No exame físico sob palpação, a área lesionada se apresenta quente, edemaciada, sensível e com presença de crepitação. Linfonodos regionais podem apresentar um aumento de tamanho, rigidez, dificuldade respiratória, taquicardia e desidratação podem ser constatadas. Se não diagnosticada a tempo, o animal pode vir a óbito entre 12 e 60 horas após a infecção. Dificilmente os animais infectados sobrevivem por mais de 5 dias (MEGID et al., 2016).

Quando a doença não é controlada com rapidez, o animal desenvolve toxemia sistêmica e choque, podendo vir a óbito. $\mathrm{O}$ animal pode apresentar temperatura normal ou elevada e anorexia. Quando a enfermidade se espalha pela musculatura, observa-se dificuldade de locomoção, aumento de volume, crepitação subcutânea devido a produção de gás causada pela bactéria, edema e hemorragia (LOBATO et al., 2013).

\subsubsection{Isolamento Bacteriano}

Para identificar a bactéria é necessário o isolamento dela, assim analisando características morfológicas e bioquímicas. Só que esse processo é demorado, levando de quatro dias a uma semana para o exame ficar pronto e requer pessoas com treinamento específico para realizá-lo (ASSIS et al., 2001).

É um procedimento laborioso o isolamento do C. chauvoei por se necessitar de um ambiente propício e anaeróbico, sem contar que a presença de outras bactérias pode acabar mascarando o cultivo. Vários métodos já foram criados para facilitar a 
identificação de clostridioses, faltando apenas um aperfeiçoamento para o transporte de amostras obtidas no campo para o laboratório (FARIAS, 2011).

\subsubsection{Achados Anatomopatológicos e Histopatológicos}

Macroscopicamente a pele se apresenta tensionada, na coloração vermelha ou preta. É possível ser observado a separação da área afetada da área sadia. Se realizada uma incisão, um líquido com presença de bolhas gasosa é extravasado (LOBATO et al., 2013). Com a grande quantidade de gás presente na musculatura, os feixes musculares podem estar separados, ela também pode apresentar necrosada. A musculatura acometida apresenta aumento de volume, necrose e hemorragia. Também pode apresentar coloração escura, sem brilho e com as fibras separadas por conta do exsudato sanguinolento. Regiões necrosadas irão estar presente no fígado e o pericárdio e epicárdio podem apresentar petéquias (MEGID et al., 2016).

Microscopicamente é observado as fibras musculares difusamente tumefeitas e fragmentadas com a presença de bacilos. Infiltração inflamatória constituída na maior parte por neutrófilos pode ser ausente ou moderada (LOBATO et al., 2013).

\subsubsection{PCR (Reação em Cadeia da Polimerase)}

É uma técnica laboratorial considerada rápida e de grande confiabilidade nos resultados que aponta (MACHADO, 2008). O exame PCR (Reação em Cadeia da Polimerase) que amplifica e conserva a sequência de subunidade $16 \mathrm{~s}$ rRNA, da subunidade 16S-23S rDNA.É essa sequência do gene que codifica a flagelina do Clostridium chauvoei (LOBATO et al., 2007). Necessita coletar o material para a identificação da bactéria. Umas das mais utilizadas por ser de alta sensibilidade e especificidade para o diagnóstico (MEGID et al., 2016).

\subsubsection{Imunofluorescência direta}

A técnica de imunofluorescência direta permite um diagnóstico rápido e seguro. É uma técnica bastante usada no diagnóstico definitivo nos quadros de carbúnculo sintomático (ASSIS et al., 2005). A imunofluorescência direta é capaz de identificar, em esfregaços de tecidos infectados, a morfologia dos bastonetes esporulados (MACHADO, 2008).

Pode ser realizada com o líquido retirado das lesões em animais vivos; e dos músculos afetados e sangue cardíaco de animais mortos. Técnica realizada em 
laboratórios especializados com conjugados específicos para o Clostridium chauvoei, entre outros (MEGID et al., 2016).

\subsubsection{Imunohistoquímica}

É uma técnica considerada bem sensível e específica para a confirmação de diagnóstico da doença (MACÊDO et al., 2013). A imuno-histoquímica se dá pela coloração das enzimas de tecidos fixados com formalina e permite um diagnóstico retrospectivo (FARIAS, 2011). Combina análise imunológica, histológica e bioquímica. Permitindo localizar o agente através de anticorpos específicos (PIRES, 2015).

\subsection{Diagnóstico Diferencial}

O edema maligno é a principal enfermidade para diagnóstico diferencial. 0 mesmo pode apresentar feridas externas parecidas com as lesões do carbúnculo sintomático, sem mencionar que também é vulneroinfeccioso (ASSIS et al., 2010). Outras enfermidades como antraz, queda de raio, hemoglobinúria bacilar e mortes súbitas também requerem um diagnóstico diferencial (MACHADO, 2008).

\subsection{Tratamento}

Pode se tornar ineficaz dependendo do momento a ser realizado, por se tratar de uma doença de rápida evolução (GREGORY et al., 2006). O tratamento deve ser realizado o mais rápido possível, com administração penicilina em doses altas (LOBATO et al., 2013); e se constitui basicamente com a administração de penicilina por via I.M durante 3 a 5 dias na dose de $20.000 \mathrm{UI} / \mathrm{Kg}$ até $40.000 \mathrm{UI} / \mathrm{Kg}$ quando associadas os três tipos, potássica, procaína e benzatina (MEGID et al., 2016). Outros antibióticos vêm sendo usados na infecção contra as doenças causadas por clostrídios, mas devido as suas susceptibilidades, acaba ocorrendo uma resistência microbiana (GREGORY et al., 2006).

O uso de penicilina e o desbridamento cirúrgico da lesão, são formas de tratamento indicadas quando o animal não estiver moribundo. A recuperação é pouco significativa devido as lesões serem extensas. Doses altas de penicilina como 44.000 $\mathrm{UI} / \mathrm{kg}$ devem ser administradas, sempre optando por começar o tratamento por administração intravenosa e depois por via muscular, que propõe uma ação mais longa. O uso da vacina não tem grande suporte para o tratamento (CONSTABLE et al., 2017). 


\subsection{Prognóstico}

O prognóstico é desfavorável. A demora do diagnóstico é o principal fator, por se tratar de uma enfermidade de rápida evolução. Caso a doença seja diagnosticada em até 24 horas desde o início da infecção, o prognóstico se torna reservado (MEGID et al., 2016). A recuperação será melhor em animais que forem tratados no início da infecção, ou naqueles que as lesões musculares não estão disseminadas (LOBATO et al., 2013).

\subsection{Medidas de Controle e Prevenção}

A erradicação do clostridium chauvoei é praticamente impossível pelo fato de o microrganismo ter predileção pelo trato digestivo dos ruminantes e pelo solo, sem mencionar que são altamente resistentes no ambiente. Desde então, os animais estão permanentemente em contato com o agente. Medidas adequadas de manejo e a vacinação do rebanho são os principais fatores a serem considerados quando se trata de controle e prevenção (LOBATO et al., 2007).

A medida de maior eficácia para a prevenção e controle da enfermidade é a vacinação. Podendo também ser adotadas medidas higiênicas como a desinfecção de agulhas e instrumentos cirúrgicos, desinfecção do curral ou onde o rebanho for manejado, descarte adequado das carcaças, entre outras (LOBATO et al., 2013).

Os animais infectados pela enfermidade, devem ser tratados logo no início dos sinais clínicos, incluindo junto ao tratamento a vacinação ou revacinação do rebanho. Vale lembrar que na primovacinação existe um período negativo da vacina que tem duração de aproximadamente 14 dias após a aplicação, podendo o animal se infectar nesse período pelo motivo de não ter tido o tempo de produção de imunoglobulina, que são as responsáveis pela a imunização (MEGID et al., 2016). As vacinas concedem uma boa imunidade aos animais, que se, diagnosticados rapidamente e corretamente a infecção pode ser controlada. Há no mercado vacinas monovalentes, para somente carbúnculo sintomático (GREGORY et al., 2006).

A vacinação dos animais deve ser realizada entre 3 a 6 meses de idade com reforço de 30 dias e revacinados após 1 ano ou 2 anos. Outro modo de vacinação também eficiente, é vacinar bezerros com 4 meses de idade reforçando a vacina à desmama. As fêmeas gestantes podem ser vacinadas no último mês de prenhes garantindo que o bezerro fique imune até os 3 meses de idade (MEGID et al., 2016). 
No geral, os bovinos devem ser vacinados ano após ano com vacinas polivalentes que os imunizam contra diferentes clostrídios. Já os ovinos, vacina-se no $3^{\circ}$ mês de vida com um reforço ao completar 1 ano, e após, anualmente. Fêmeas gestantes devem ser revacinadas 30 dias antes do parto. Pela grande variedade de vacinas comerciais e pelo pouco estudo das mesmas, se torna comum a ocorrência da doença mesmo em animais vacinados (MEGID et al., 2016).

Falhas vacinais, presença de cepas diferentes as da vacina utilizada também são fatores a serem considerados. Cabe ao Médico Veterinário salientar aos produtores a importância de se ter conhecimento sobre os fatores citados. As carcaças de animais infectados devem ser queimadas ou enterradas em covas com profundidade de 2 metros, fazendo o uso adicional de cal em baixo e em cima das mesmas (MEGID et al., 2016).

Nem sempre a vacinação protege totalmente o rebanho. Pode ocorrer uma mutação do microrganismo dependendo se há presença de diferentes cepas na região. É de responsabilidade do Médico Veterinário instruir os proprietários sobre a importância da existência de cepas de diferentes regiões (GREGORY et al., 2006).

A doença limita a prevenção e o controle dela. A união dos produtores junto ao órgão de vigilância tem suma importância, pois nem todos os casos de carbúnculo sintomático são relatados, dificultando ainda mais seu controle. Se todos os criadores de gado tivessem a conscientização, realizando medidas preventivas, seria de maior facilidade controlar e prevenir a doença (WOLF et al., 2017).

\section{CONSIDERAÇÕES FINAIS}

O carbúnculo sintomático é uma doença de caráter agudo e tem com seu agente etiológico o Clostridium chauvoei. Essa enfermidade tem grande importância na Medicina Veterinária por acometer animais, principalmente da espécie bovina em todo o mundo, causando assim, um grande impacto econômico. Apesar de um pequeno avanço no entendimento da doença e de seu agente etiológico, ainda são poucos os estudos relacionados aos mecanismos dela.

Se fossem realizados estudos dentre os estados brasileiros para a identificação da real prevalência das clostridioses no nosso meio, seria de fundamental importância, 
pois existiria um conhecimento mais específico. Sendo assim, com um estudo mais abrangente, poderíamos tornar mais eficaz a composição antigênicas das vacinas, promovendo uma profilaxia mais efetiva da doença.

Com a conscientização dos produtores e a instrução dos Médicos Veterinários para os mesmos, teríamos um grande controle sobre essa enfermidade. Garantindo assim uma alta produtividade de animais com qualidade, visando a exportação da carne e de animais com alto valor genético; aumentando a lucratividade do proprietário e do país.

\section{REFERÊNCIAS}

ALAM, Nur Md et al. Isolation and Identification of Clostridium chauvoei From Cattle in Mymensingh City of Bangladesh. Fundamental and Applied Agriculture, vol.4, p.649-654, out. 2018.

ANDRADE, Ricardo Guimarães; BOLFE, Édson Luis; BATISTELLA, Mateus. Sustentabilidade da Bovinocultura. Agroanalysis, p.29-31, jan. 2015.

ASSIS, Ronnie et al. Mionecroses Clostridiais Bovinas. Arquivo Instituto Biológico, São Paulo, v.77, n.2, p.331-334, abr/jun. 2010.

ASSIS, Ronnie et al. Reação em cadeia da polimerase para deteç̧ão de Clostridium chauvoei em tecidos de Cavia porcellus. Pesquisa Agropecuária Brasileira, Brasília, v.40, n.12, dez. 2005.

ASSIS, Ronnie Antunes et al. Surto de Carbúnculo Sintomático em Bezerros. Ciência Rural, Santa Maria, v.35, n.4, p.945-947, jul-ago. 2005.

BARROS, C. S. L. Sistema muscular. In: SANTOS, R. L.; ALESSI A. C. (Eds). Patologia veterinária. 2.ed. São Paulo: Roca, 2016. P.663-702.

CONSTABLE P.D., Hinchcliff K.W., Done S. H., Grunberg W. 2017. A Textbook of the Diseases of Cattle, Horses, Sheep, Pigs, and Goats. 11th edition (Elsevier Ltd.); pp 1431-1432.

FARIAS, Luana D’Avila. Carbúnculo Sintomático: Abordagem Diagnóstica e Imunológica. 2011. 60f. Dissertação (mestrado) - Universidade Federal de Santa Maria.

FREY, J.; FALQUET, L. Patho-genetics of Clostridium chauvoei. Research in microbiology. P.384-392, 2015. 
GREGORY, L et al. Carbúnculo Sintomático: ocorrência, evolução clínica e acompanhamento da recuperação de bovino acometido de "manqueira". Arquivo Instituto Biológico, São Paulo, v.73, n.2, p.243-246, abr/jun. 2006.

GROSETH, P. K et al. Large outbreak of blackleg in housed cattle. Veterinary Record, v.169, n.13, p.339-339, 2011.

HECKLER, F. Rubiane et al. Carbúnculo Sintomático em Bovinos em Mato Grosso do Sul: 59 casos. Pesquisa Veterinária Brasileira, v.38, n.1, p.6-14, jan. 2018.

LOBATO, Francisco Carlos Faria et al. Clostridioses de Animais de Produção. Veterinária e Zootecnia, v.20, p.29-48, 2013.

LOBATO, Francisco Carlos Faria et al. Clostridioses dos Pequenos Ruminantes, RPCV, v.102, p.23-34, 2007.

MACÊDO, Juliana Targino Silva Almeida et al. Edema maligno em equino causado por Clostridium chauvoei. Acta Scientiae Veterinariae, Porto Alegre, v.41, n.1, p.1-4, out. 2013.

MEGID, Jane et al. Carbúnculo Sintomático. In: doenças infecciosas em animais de produção e de companhia. 1.ed. Rio de Janeiro: Roca, 2016. Cap.15, p.155-160.

PEREIRA, Diego Rodrigues. Manejo Sanitário em Bovinos de Corte. Seminário de Ensino, Pesquisa e Extensão na Graduação, Goiás v.1, n.2, p.69-72, 2014.

PIRES, Prhiscylla Sadaña. Relação parasito-hospedeiro na infecção de macrófagos por Clostridium chauvoei. 2015. 69f. Tese (doutorado) - Universidade Federal de Minas Gerais.

STRINGER, C. Sandra et al. Lag time variability in individual spores of Clostridium botulinum. Food Microbiology, v.28, n.2, p.228-235, 2011.

WOLF, R. et al. Spatial-temporal cluster analysis of fatal Clostridium chauvoei cases among cattle in Styria. Preventive Veterinary Medicine, Austria, v.138, p.134138, jan. 2017.

ZIECH, Rosangela Estel. Carbúnculo sintomático: compreensão atual e futuras necessidades de pesquisa. Ciência Rural, vol.48, n.5, maio. 2018. 


\title{
CAPÍtuLO $v$
}

\section{CINOMOSE CANINA - ETAPAS DO PROCESSO SAÚDE- DOENÇA E PATOGENIA}

\author{
D미: 10.51859/amplla.pdi443.1121-5
}

Flávia Rodrigues Araujo ${ }^{1}$

Andresa de Cássia Martini ${ }^{2}$

Eric Mateus Nascimento de Paula ${ }^{2}$

\footnotetext{
${ }^{1}$ Médica Veterinária Autônoma. Egressa do Curso de Medicina Veterinária do Centro Universitário de Mineiros UNIFIMES

${ }^{2}$ Docente do Curso de Medicina Veterinária do Centro Universitário de Mineiros - UNIFIMES.
}

\section{RESUMO}

As doenças infecciosas, são muito comuns em rotinas clínicas de pequenos animais, algumas mais fáceis de serem diagnosticadas e tratadas do que outras. Um exemplo muito comum de doença infecciosa em cães é a cinomose, no entanto, é uma enfermidade bastante preocupante por apresentar uma alta taxa de mortalidade. 0 objetivo deste trabalho é abordar a patogenia da cinomose canina, descrevendo todas as etapas do processo saúde-doença. Para tanto, realizou-se uma revisão de literatura baseada em livros nacionais atuais e artigos acadêmicos que abordassem o tema de doenças infecciosas em animais de companhia. A cinomose canina é uma enfermidade de distribuição mundial, de característica multissistêmica e altamente contagiosa, que acomete diversas espécies de carnívoros, domésticos e selvagens. Contudo, ela é mais preocupante para os cães domésticos (Canis familiaris), que também são os principais reservatórios do vírus. É também conhecida por ser uma doença febril e sua forma de infecção é rápida, principalmente nos filhotes e/ou imunossuprimidos. Não existe tratamento específico para esta enfermidade, sendo a prevenção, vacinação, e cuidados individuas de manejo e higiene, são zas melhores formas de tratamento.

Palavras-chave: Cães. Epidemiologia. Morbillivirus. Patogênese.

\section{INTRODUÇÃO}

As doenças infecciosas estão intimamente ligadas com a tríade epidemiológica, que envolve o hospedeiro, o agente etiológico e o ambiente. O hospedeiro é o animal susceptível, o agente infeccioso consiste nos organismos patogênicos que irão provocar a doença no animal, alguns exemplos destes são: as bactérias, vírus e protozoários. Por 
fim, o ambiente, que é o local onde ocorre o contato dos hospedeiros com os agentes infecciosos (MEGID et al., 2016).

Doenças infecciosas são comuns de serem encontradas nos animais domésticos, em especial, quando tratamos de cães e gatos. Os cães por exemplo, são animais bastante susceptíveis as infecções principalmente virais. Dentre estas, podemos destacar a cinomose canina, hepatite infecciosa canina, herpesvírus canino, parvovirose canina e a raiva (MEGID et al., 2016). As mais frequentemente diagnosticadas em rotinas clínicas são, a parvovirose e a cinomose, sendo a cinomose uma das mais preocupantes para os cães, devido ao grande número de óbitos, ficando atrás somente da raiva (MARTINS et al., 2009).

A cinomose canina é uma doença infectocontagiosa, multissistêmica, provocada por um vírus, e, não é uma zoonose. Pode infectar várias espécies de carnívoros, como raposas, lobos, e furões, o que vem contribuindo para a diminuição da população destes animais selvagens, devido à alta taxa de morbidade (MARTINS et al., 2009), no entanto, os cães domésticos são os principais acometidos.

Este trabalho apresenta como objetivo o esclarecimento da patogenia da cinomose canina, descrevendo todas as etapas do processo saúde-doença, sinais clínicos, e meios de identificação da enfermidade, buscando assim um diagnóstico precoce, favorecendo um tratamento eficaz, e também, ressaltando a importância da prevenção e vacinação, visto que, esta é uma enfermidade de grande importância para a clínica médica de pequenos animais.

\section{REVISÃO DE LITERATURA}

\subsection{Definição}

A cinomose canina dentre as doenças infectocontagiosas, é uma das mais preocupantes para os cães domésticos. É causada por um vírus da família Paramyxoviridae, do gênero Morbillivirus. Esse agente também pode infectar outros carnívoros como furões, raposas e lobos (NORRIS et al., 2006). Segundo Greene e Vandevelde (2012) os cães domésticos são os principais reservatórios do vírus. Trata-se de uma enfermidade multissistêmica grave, que leva o animal a um estado de imunossupressão, deixando-o assim susceptível a infecções secundárias (ALMEIDA., 
2016). Apesar de desencadear diversas alterações no organismo, a principal causa de morte nos animais acometidos se dá pela gravidade das lesões que o vírus provoca no sistema nervoso central (ORSINI; BONDAN, 2008).

Devido à gravidade desta enfermidade, os animais que são acometidos quase sempre morrem naturalmente, ou mesmo são eutanasiados, por apresentarem sinais incompatíveis com a vida. A população canina que consegue sobreviver, normalmente apresentam graves sequelas neurológicas para o resto da vida (SILVA et al., 2007; CURTI et al., 2012; SILVA et al., 2015).

\subsection{Histórico}

A cinomose canina foi descrita pela primeira vez na América do Sul no ano de 1746. Anos depois, por volta de 1760 a doença já era comum em diversos países como na Espanha, Itália, Rússia e Inglaterra. Um acontecimento marcante, foi em 1763 em Madri, que aproximadamente 900 cães morreram em um mesmo dia e esta alta mortalidade foi relacionada ao vírus da cinomose canina (MARTINS; LOPES; FRANÇA, 2009).

Isolaram o patógeno causador da moléstia pela primeira vez em meados do século XX, que mais tarde, foi apresentado por Carré no ano de 1905 por meio de inoculação da secreção nasal de cães enfermos para cães jovens sadios, simulando experimentalmente a doença (MELLO et al, 2008).

No início do século XX a cinomose canina foi uma das principais moléstias fatais mais comum entre os cães no mundo. Por volta dos anos 60 , foram criadas vacinas específicas e a atual realidade mudou. Contudo, a mortalidade ainda era frequente na população canina que não recebia a vacina ou nos vacinados, que constatavam falhas vacinais (SILVA, 2004). Estudos sobre a cinomose incluindo dados de etiologia, patogenia, epidemiologia, imunologia e algumas técnicas de diagnóstico vem sendo estudadas por mais ou menos dois séculos e, as informações sobre a fase neurológica e histopatológica da enfermidade, foram relatadas especialmente entre as décadas de 1940 e 1950 (SILVA et al., 2009).

\subsection{Agente Etiológico}

A enfermidade é causada por um vírus conhecido como vírus da cinomose canina (VCC), pertencente da família Paramyxoviridae e do gênero Morbillivirus. É pleomórfico, 
possui envelope, polaridade negativa e é um capsídeo de simetria helicoidal chegando a medir de 150 a 300 nanômetros (QUINN et al., 2005). É um RNA-vírus de fita simples, que infecta as células de vários sistemas do organismo animal (MARTINS et al., 2009).

Quando falamos de características morfológicas e aspecto antigênico o agente é especificamente associado ao vírus da peste bovina e do sarampo humano (LÚClO et al., 2014). Se tratando de morfologia, o VCC possui seis proteínas estruturais, três delas (L, $\mathrm{N}, \mathrm{P})$ são internas e as outras três (M, H, F) são externas e estão anexadas ao envelope. A proteína $\mathrm{N}$ é responsável pela proteção do material genético, enquanto as proteínas L e P são encarregadas de realizar a transcrição e replicação do RNA viral. A proteína M (matriz) atua na maturação do vírus e atua como junção das glicoproteínas da superfície ao nucleocapsídeo. A proteína $\mathrm{F}$ (fusão) realiza a fusão da partícula viral com a célula do animal, e por fim, temos a proteína $\mathrm{H}$ (hemaglutinina) que realiza a absorção, sendo variável pois depende da resposta imune do hospedeiro, como também é a causa da diversidade antigênica do VCC (ORSINI; BONDAN, 2008).

Figura 1 - Ilustração representando o VCC

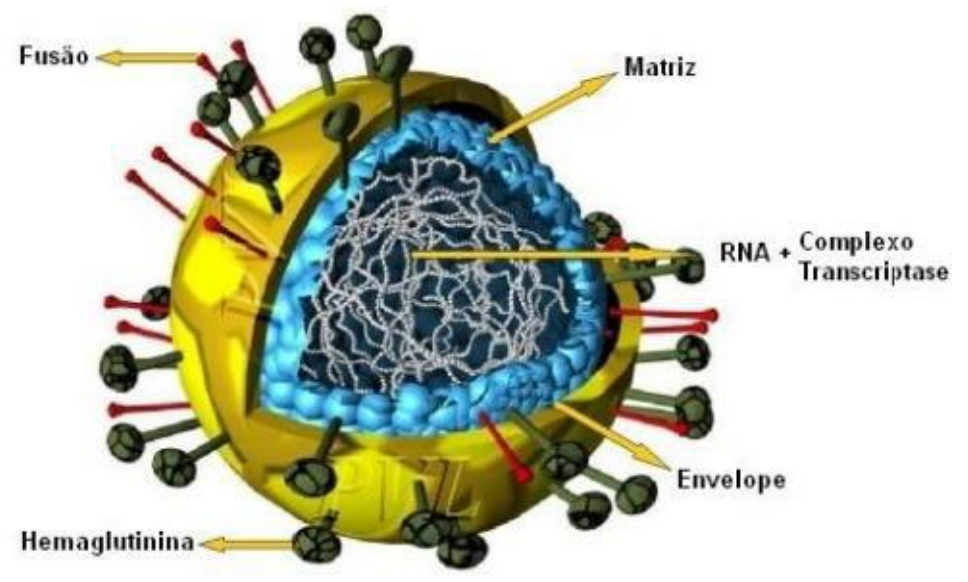

Fonte: (FREITAS, 2017).

Existe apenas um sorotipo do vírus, contudo encontram-se cepas biologicamente diferentes, algumas mais virulentas do que outras, o que vai interferir na manifestação da doença no animal, podendo ser leves ou agudas graves (FREITAS, 2017). Este vírus tem tropismo por linfócitos e órgãos linfoides, o que explica o estado de imunossupressão do animal e a predisposição a infecções secundárias (ALMEIDA et al. 2009). 
Este patógeno pode sobreviver por anos quando se encontra em temperaturas mais frias como a $-65^{\circ} \mathrm{C}$, no entanto ele é destruído em temperaturas de 50 a $60 \circ \mathrm{C}$ com uma duração de 30 minutos (GREENE e VANDEVELDE, 2012). Também pode ser destruído por detergentes, solventes lipídicos, desinfetantes e luz ultravioleta (NELSON et al., 2006).

Segundo Sherding e Birchard (2008), o vírus sobrevive por pouco tempo no ambiente, apenas algumas horas. É interessante frisar que, o patógeno possui um pH variável, o que impossibilita sua sobrevivência no estômago e intestino delgado. Além de que o agente possui uma camada lipídica que o recobre, chamada de envelope, que por sua vez é sensível aos sais biliares, assim, pode ser inativado por alguns desinfetantes que tenham amônia quaternária em sua composição, assim como o formol, fenol e detergentes também ajudam na eliminação do vírus no ambiente (SANTOS, 2006).

\subsection{Epidemiologia}

\subsubsection{Distribuição Geográfica}

A cinomose canina acontece em todo o mundo, mas em países onde se realiza a vacinação regular dos cães, a doença clínica tem diminuído consideravelmente, tendo apenas relatos de casos esporádicos (NEGRÃO et al., 2006). A cinomose tem distribuição mundial e como o vírus é muito fatal em animais de vida livre, ela vem colaborando com a extinção de alguns animais selvagens na África e na América do Norte (MARTINS; LOPES; FRANÇA, 2009). No mundo, há uma maior ocorrência da enfermidade em países que são subdesenvolvidos, devido a negligência quanto ao manejo sanitário da população canina (LOPES, 2007)

De acordo com Oliveira et al (2009), no Brasil a cinomose é endêmica, representando um total de $11 \%$ das mortes em cães. Acredita-se que até $50 \%$ dos cães tem a infecção subclínica e que a população mais acometida são os cães filhotes e os imunossuprimidos (MARTINS; LOPES; FRANÇA, 2009). Estudos mostram que o VCC tem uma maior sobrevivência no ambiente nos meses de inverno, o que leva os animais a serem mais acometidos nesta época do ano (MONTI, 2004). 


\subsubsection{Cadeia Epidemiológica}

\subsubsection{Fonte de infecção}

Os animais infectados podem ou não apresentar sinais clínicos, sendo estes importantes na cadeia epidemiológica pois são fonte de infecção para os outros animais susceptíveis. Os animais infectados eliminam o vírus no ambiente por isso são considerados os principais reservatórios do VCC (GEBARA et.al., 2004; NEGRÃO et al., 2007).

De acordo com Santos (2006), os animais infectados podem eliminar o vírus no ambiente até 90 dias pós infecção, mas uma maior carga viral é eliminada principalmente na fase aguda, entre as duas primeiras semanas de infecção. Já os animais que apresentam apenas os sinais do sistema nervoso, eliminam uma menor carga viral no ambiente, por se tratar de uma infecção já no estágio crônico.

É importante frisar que muitos animais que já tiveram contato com a doença podem não a ter manifestado em sua forma clínica, fator que explica o caso de alguns animais possuírem imunidade ao vírus. Contudo, este acontecimento é visto como negativo, pois este animal assintomático acaba disseminando o vírus para outros animais, mesmo estando saudável (MARTINS; LOPES; FRANÇA, 2009).

\subsubsection{Vias de eliminação}

A eliminação acontece através da exposição do vírus ao ar, que os animais infectados liberam a partir de suas excreções, como saliva, urina e fezes (QUINN et al., 2005, LITFALLA et al., 2008). E eliminam também através de suas secreções, como: nasais, oculares, leite, sangue, placenta e restos placentários, como também restos fetais (MARTINS; LOPES; FRANÇA, 2009).

\subsubsection{Meio de Transmissão}

Os cães se infectam pela inalação de aerossóis ou ingestão de partículas virais infectantes presentes em amostras biológicas, já mencionadas. Quando infectados estes animais apresentam sinais respiratórios, digestórios e neurológicos (GREENE e VANDEVELDE, 2012). Por isso é importante evitar aglomeração de animais e impedir o contato dos animais sadios com os enfermos, quebrando assim o ciclo de transmissão da doença (SANTOS, 2006). 
Podendo ainda ocorrer, em menor frequência, a transmissão transplacentária (SHERDING e BIRCHARD, 2008). Esta forma de transmissão pode ocorrer até 90 dias depois que a cadela foi infectada (MARTINS et al., 2009; NELSON e COUTO, 2010). De acordo com Greene e Vandevelde (2012), os filhotes infectados por essa via, se sobreviverem, apresentarão imunodeficiência devido os danos causados aos órgãos linfoides.

\subsubsection{Porta de entrada}

A porta de entrada mais comum é a via respiratória, acometendo o trato respiratório superior, mas os animais podem se infectar por meio da via digestiva ou conjuntival (MONTI, 2004).

\subsubsection{Hospedeiros susceptíveis}

Quando temos locais em que existem muitos animais aglomerados, como clínicas veterinárias, canis, abrigos, dentre outros, a disseminação do vírus se torna mais rápida (SANTOS, 2006). Segundo Gebara (2004), os cães domésticos são os animais mais susceptíveis a esta enfermidade, e Monti (2004) completa que os animais silvestres também são importantes hospedeiros susceptíveis.

De acordo com Megid et al (2016), além da família Canidae, que inclui o cão doméstico, coiote, guaxinim, raposa e lobo, o VCC infecta também outras famílias, como a Mustelidae (furão, vison, marta, glutão), Felidae (cheeta, leão, jaguar), Ursidae (urso panda), Tayassuidae (queixada, porco-do-mato), Cercopithecidae (macacos), entre outras famílias.

Há relatos também de que a cinomose pode acometer mamíferos aquáticos como as focas. O primeiro relato foi em 1955, na Antártica, onde uma considerável quantidade de focas (Lobdon carcinophagus) morreram, fato explicado por haver uma comunidade de cães não vacinados contra cinomose no mesmo habitat das focas, indicando que os cães transmitiram a infecção para as focas (MEGID et al., 2016).

Segundo Hoskins (2008), a doença é mais comum em cães filhotes que estão entre 3 a 6 meses de idade, em que relata que o animal se torna susceptível a cinomose devido a ausências dos títulos de anticorpos maternos, o que varia de um animal para outro. $\mathrm{O}$ agente tem maior predileção por filhotes e animais que não foram vacinados. Porém, pode acometer animais de qualquer raça, idade ou sexo (MARTELLA et al., 2008). 


\subsection{Patogenia}

O VCC quando entra em contato com o organismo do animal, pode se replicar em diversos tipos celulares, porém, os órgãos linfóides são os mais susceptíveis, de onde o vírus irá se disseminar por todo organismo do animal, levando a uma consequente queda da imunidade. São exemplos destes órgãos o baço, timo, linfonodos, e a medula óssea (BARBOSA et al., 2011).

Após o contato do cão com a partícula viral por meio de aerossóis, por via digestiva ou conjuntival, o vírus entra no organismo e é fagocitado. Passado 24 horas deste contato, o vírus é transportado pelo sistema linfático para as tonsilas, onde ocorre a primeira replicação. Posteriormente, o vírus se dissemina para os órgãos linfoides, como timo medula óssea e baço (MANGIA, 2008). O patógeno também pode se multiplicar em órgãos como estômago, intestino delgado e fígado, que em seguida, irá levar a primeira viremia. Nos locais de infecção, temos uma infecção dos linfócitos, gerando a apoptose e com isso levando a queda de imunidade do animal, completa Barbosa et al. (2011).

Devido a multiplicação do patógeno nos órgãos linfoides, consequentemente levará a imunossupressão do animal, o que é uma porta de entrada para infecções secundárias, e, é um fator que explica a alta taxa de mortalidade da doença (GREENE e VANDEVELDE, 2012). Por consequência da elevada replicação do vírus nos órgãos linfoides e a disseminação do mesmo por todo organismo, haverá entre o segundo e sexto dia pós-infecção, o primeiro pico febril (RIBEIRO; TORRES, 2014). Após oito a dez dias pós-infecção o vírus se dissemina por meio da via hematógena para tecidos do trato respiratório, gastrintestinal e geniturinário. Dependendo da resposta celular ou humoral do hospedeiro, o patógeno também pode se disseminar através do liquor. Segundo Greene e Vandevelde (2012), quando VCC se propaga para os tecidos epiteliais. Ocorre uma eliminação viral para o ambiente, mesmo o cão apresentando sintomas ou não.

Animais com níveis razoáveis de anticorpos e resposta imune, aos 14 dias pósinfecção, podem disseminar o vírus antes mesmo de apresentarem os sintomas da doença. Já os cães com uma boa resposta imune, terão uma menor propagação viral no organismo, e por consequência, a ausência da doença clínica. Quando os cães apresentam uma ótima resposta imune, com altas taxas de anticorpos, os mesmos têm capacidade de debelar o vírus e evitar que ele se dissemine por tantos órgãos, levando 
assim a ausência da doença clínica. Mesmo com uma boa imunidade, os anticorpos não conseguem destruir o vírus de alguns tecidos, como os neurônios, tecido uveal e tegumentar (GREENE; VANDEVELDE, 2012).

Alguns fatores interferem na infecção do vírus no sistema nervoso central (SNC), como a cepa viral, idade e imunidade do animal acometido, assim, os cães não vacinados e os filhotes, tem uma maior chance de desenvolver esta fase da doença (SILVA et al., 2007). Ainda não se sabe ao certo a forma que o vírus usa para adentrar o SNC. Silva et al. (2009), acreditam que seja pela via hematógena, fazendo com que células infectadas atravessem a barreira hematoencefálica. Já Beineke et al. (2009), apresentam outra teoria de que o vírus consegue alcançar o SNC por meio do líquido cefalorraquidiano, com base de que na maioria das vezes, as lesões provocadas pelo vírus são no encéfalo.

Silva et al. (2009), também acrescenta que mesmo se os animais acometidos não estejam apresentando os sinais neurológicos da doença eles terão a presença do vírus no SNC. Nelson e Couto (2010), complementam em outras palavras, que a grande parte dos animais infectados terão a presença do vírus no SNC, porém, só apresentarão sinais clínicos neurológicos, aqueles que tem pouca ou nenhuma resposta imune.

\subsection{Sinais Clínicos}

A cinomose é conhecida por ser uma doença febril, multissistêmica, e o seu agente viral replica-se principalmente no tecido linfoide, e em sua fase aguda, seu principal sintoma é uma febre transitória, com temperatura que pode chegar de 39,5ำ a 41 ํㅡ, tendo início até o 7으 dia pós-infecção, sem apresentar outros sinais da doença (HOSKINS, 2008). Após este pico febril a temperatura do animal se normaliza até o 14응 dia, que é quando vai ocorrer outro pico febril, só que desta vez acompanhada de sinais como apatia, desidratação e depressão (SHERDING e BIRCHARD, 2008).

Os cães acometidos pela moléstia apresentam sinais respiratórios como rinite, tosse, dispneia; também sinais gastrointestinais, bem como alterações tegumentares, em alguns casos nota-se a presença de pústulas e hiperqueratose dos coxins; e também alterações oftalmológicas, podendo ter o surgimento de uveíte, degeneração de retina e podendo até culminar em cegueira (AMUDE et al., 2006; MARTINS et al., 2009; SILVA et al., 2015). Nota-se ainda, nos cães acometidos a presença de ceratoconjuntivite seca, 
resultante de um comprometimento da glândula lacrimal, que gera desconforto ao animal, além da redução de produção aquosa (NELSON e COUTO, 2010).

Figura 2 - Cão com 5 meses de idade infectado pelo CDV, apresentando secreção mucopurulenta

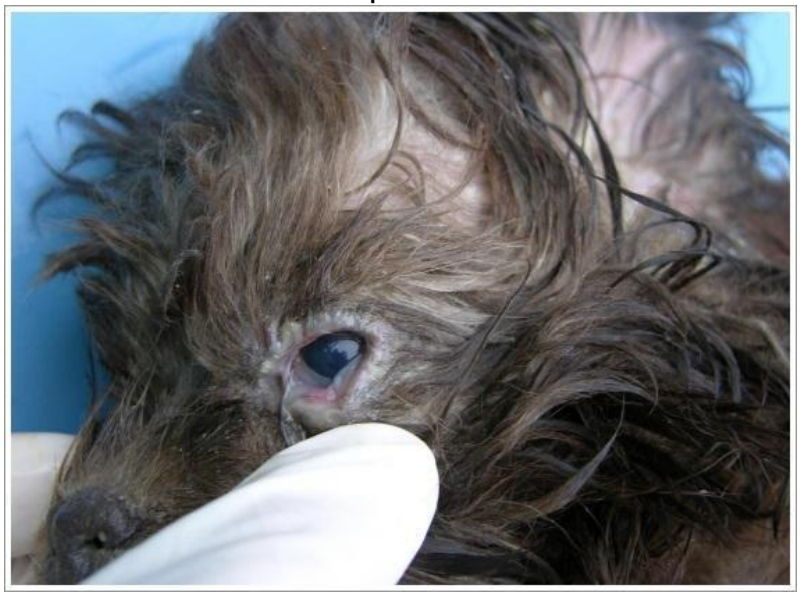

Fonte: SONNE et al. (2009).

Quando falamos de sinais gastrointestinais podemos observar a ocorrência de enterite e gastrite, devido as mucosas do intestino e estômago se apresentarem inflamadas, o que leva o animal a ter quadros de vômito e diarréia, a mesma podendo ser mucosanguinolenta, levando o animal a desidratação e a perda de peso respectivamente (MARTINS et al., 2009; DIAS et al., 2012; SILVA et al., 2015).

Se tratando de sinais neurológicos, podemos destacar que, esta fase onde os sinais começam a serem notados, o animal já está bastante imunossuprimido e com isso, em um estágio mais crítico da doença. Os sinais mais rotineiramente observados são, convulsões; contrações involuntárias rítmicas (podendo ser de um ou mais grupos de músculos); paralisia de membros, tremores, nistagmo, vocalização, micção e defecação involuntárias (NASCIMENTO, 2009).

Figura 3 - Cão com cinomose durante crise convulsiva

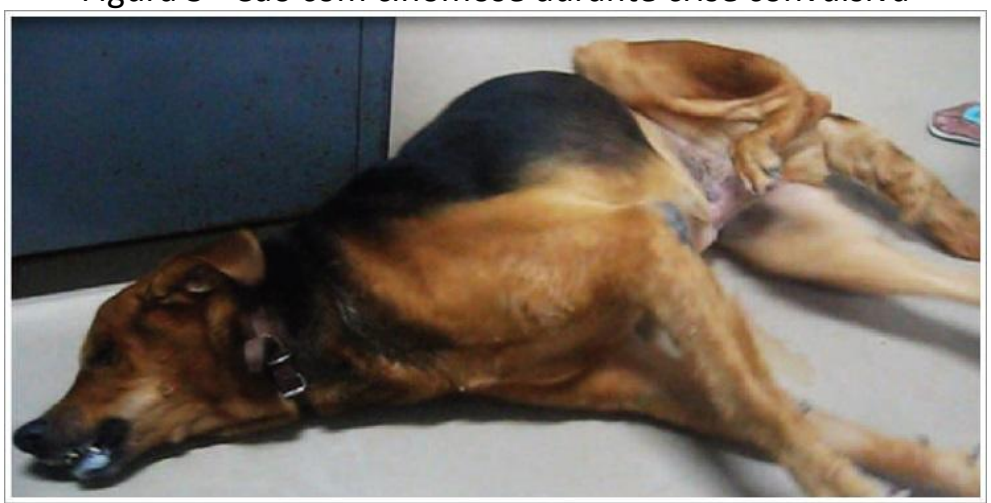

Fonte: Revista CÃES \& GATOS. Edição 161. 2012. 
Os danos causados pelo vírus no SNC se manifestam clinicamente em três formas clínicas: encefalomielite do cão jovem, de característica aguda e grave, e sua ocorrência acontece juntamente com sinais clínicos e neurológicos; encefalomielite multifocal do cão adulto, apresenta característica crônica, e as disfunções neurológicas podem ou não acompanhar os sinais clínicos; encefalite do cão idoso, acontece comumente em cães com mais de 6 anos, apresenta em caráter crônico e inflamatório, decorrente de uma persistência viral no SNC após infecção pelo VCC em animais imunocompetentes (MEGID et al., 2016).

Devido ao estado debilitado e imunossuprimido que o animal se encontra por conta do vírus, facilita o aparecimento de infecções bacterianas oportunistas, que na grande maioria é responsável pela alta mortalidade dos animais (MARTINS et al., 2009; SILVA et al., 2015). A infecção bacteriana mais notada entre os animais que estão acometidos pela cinomose, é causada pela Bordetella bronchisseptica (NELSON e COUTO, 2010), levando o animal apresentar sinais de tosse úmida e produtiva, taquipnéia, dispneia, e também crepitação pulmonar (CARVALHO et al., 2012; DIAS et al., 2012). Além disto, os cães com estes sinais, também poderão apresentar secreções nasais e oculares (LÓPEZ et al., 2007). De acordo com Ribeiro e Torres (2014), as fêmeas acometidas pela enfermidade que estejam prenhes, podem transmitir o vírus para o feto, por meio da via trasplacentária, pois já se pôde observar sinais clínicos da cinomose em filhotes recém-nascidos.

Todos os sinais clínicos descritos podem se apresentar em conjunto, ou até mesmo um de cada vez (SILVA et al., 2009). A associação de alguns sinais clínicos, como por exemplo, alterações neurológicas juntamente com febre, corrimento ocular e diarreia, contribui muito para o diagnóstico precoce da cinomose (FREITAS, 2017). A virulência do vírus infectante, tem efeito direto na recuperação do animal, e no tempo de duração da doença, contudo, mesmo se o animal se recuperar, é comum observar sequelas neurológicas na maioria dos casos (MONTI, 2004).

\subsection{Diagnóstico}

O diagnóstico clínico, baseado na anamnese, exame físico e alguns exames complementares, na maioria das vezes pode ser inconclusivo, pois os mesmos sinais podem ser observados em outras doenças infecciosas (LATHA et al., 2007; BARBOSA et 
al., 2008). O vírus pode estar presente em várias amostras biológicas em diferentes estágios da infecção e com titulação variada (NEGRÃO et al., 2007). Quando se tem um método sensível de diagnóstico ante mortem, é possível tomar medidas de tratamento e profilaxia para que o animal tenha uma boa recuperação (GEBARA et al., 2004).

Existem várias técnicas de exames que podem ser feitos para confirmação da cinomose. Destacam-se: hemograma; esfregaço sanguíneo; imunohistoquímica, imunofluorescência, isolamento viral em cultivo celular, RT-PCR e, frequentemente, tem sido usado um kit de imunoensaio cromatográfico (NEGRÃO et al., 2007, NONINO et al., 2012). Devido alguns destes exames apresentarem limitações, como por exemplo, o manuseio das amostras biológicas coletadas, o tempo para concluir o resultado, e custo, estes métodos de diagnóstico se tornam pouco utilizados, e geralmente, os diagnósticos são feitos por anamnese, sinais clínicos, histórico e achados hematológicos.

\subsubsection{Hemograma}

Como sabemos, cada animal tem uma resposta imunológica diferente. Sendo assim, no hemograma, por conta das infecções bacterianas podemos ter na maioria das vezes uma linfopenia, alteração característica desta doença, juntamente com a trombocitopenia (GREENE e VANDEVELDE, 2012). A medula óssea por ser um dos locais de replicação, a produção de células de defesa se torna prejudicada, levando um quadro de neutropenia. Esta produção também pode ser afetada pelo fato do estresse que a doença provoca, juntamente com outros sinais, como anemia, monocitopenia, e leucocitose com desvio a esquerda (MARTINS et al., 2009) (BARBOSA et al., 2011). Outra alteração que pode ser encontrada é a hipoproteinemia, que se justifica pelo fato do comprometimento gastrointestinal e pela queda de ingestão proteica (SILVA et al., 2004).

Entretanto, não se consegue realizar o diagnostico exato da enfermidade somente por estes dados hematológicos, pois estes podem sofrer influência da cepa viral infectante, como também a presença ou não das infecções secundarias oportunistas (GEBARA et al., 2004).

\subsubsection{Esfregaço}

É um método diagnóstico realizado com sangue coagulado, por meio de raspados, das tonsilas ou conjuntiva, em que se pode encontrar os corpúsculos de Lentz 
ou corpúsculos de inclusão da cinomose. Os corpúsculos poderão estar presentes em tecidos, como, bexiga, conjuntiva, estomago, pulmão e até mesmo nas células do SNC (SONNE et al., 2009). Este achado é considerado patognomônico desta doença, pois os corpúsculos são resíduos encontrados após a replicação do vírus. Contudo, eles são encontrados apenas na fase de viremia desta enfermidade, o que define o efeito citopático do vírus sobre as células e tecidos (SILVA et al., 2005). Porém, este não é o método diagnostico mais eficaz e recomendado, pois nem sempre os animais infectados apresentarão estes corpúsculos, sendo assim, a ausência dos corpúsculos não exclui a infecção pelo vírus da cinomose.

Figura 4 - Fotomicrografia de células apresentando inclusão de Lentz (setas) em um cão com cinomose
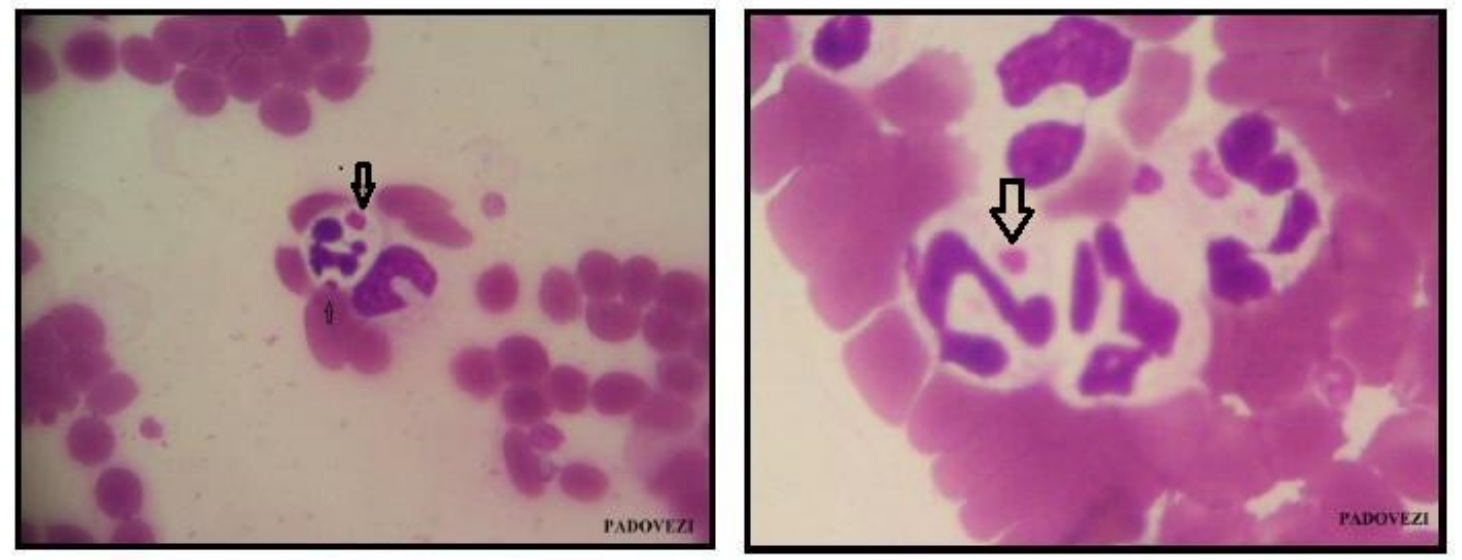

Fonte: SONNE et al. (2009).

\subsubsection{Imunohistoquímica}

É um exame que pode ser realizado utilizando amostras de mucosa nasal, epitélio dos coxins, e pele, mais especificamente, tecido do pescoço dorsal. Entretanto, este exame também tem resultados melhores na fase aguda da infeç̧ão. Este método também pode ser usado para diagnóstico pós mortem, no entanto, são utilizadas amostras diferentes, como pulmão, linfonodos, tonsilas, tecido do baço, cérebro, entre outros, (BRAZ, 2009).

\subsubsection{Imunoflourescência}

Este método pode ser realizado de duas maneiras: imunoflourescência direta (IFD) ou imunoflourescência indireta (IFI). No método IFD utiliza-se um corante, isoticionato de fluoresceína (ITFC), que marca o anticorpo anti-cinomose. Na IFI o procedimento e dividido em duas etapas, na primeira etapa, um anticorpo anti- 
cinomose não marcado é introduzido, na segunda etapa é adicionado um anticorpo antiimunoglubulina. Para realização destes exames poderão ser utilizados esfregaços nasal, conjuntival, sanguíneo e impressão de genital (BRAZ, 2009).

Braz (2009), completa ainda que, cada amostra tem o tempo para o vírus ser encontrado, como por exemplo, no sangue, ele pode ser encontrado desde o quarto dia pós-infecção (PI), já nas amostras conjuntivais, o patógeno será detectado a começar do nono dia $\mathrm{PI}$, e as amostras genitais serão positivas entre o sétimo ao décimo dia PI.

\subsubsection{Isolamento viral}

É realizado através da inoculação de amostras biológicas em células de linhagem. As amostras utilizadas podem ser de: secreções, nasal ou ocular, ou amostras de sangue. Os resultados encontrados podem ser, arredondamento celular, lise celular, formação de sincício, entre outros (BRAZ, 2009). Neste exame, é possível observar a presença do corpúsculo de inclusão, tanto intranuclear como também intracitoplasmático, finaliza Braz (2009).

\subsection{6. $R T-P C R$}

Reação em Cadeia pela Polimerase precedida de Transcrição Reversa. A técnica de RT-PCR tem obtido sucesso na detecção do VCC, pois além de poder utilizar uma diversidade de amostras biológicas, como sangue, urina, soro, e fragmentos de órgãos (neste caso para exames post mortem), oriundas de animais com sinais sistêmicos e/ou neurológicos, apresenta rapidez em seus resultados, e a infecciosidade da partícula viral não interfere no resultado final (BRAZ, 2009).

Recentemente, foi constatado que a urina, é a amostra mais sensível para detecção do vírus pela PCR, e visando que na maioria das vezes, apenas o diagnóstico clínico não é possível para detectar a infecção, este método é o mais indicado por ter mais sensibilidade (AMUDE et al., 2006; SANTOS, 2006).

\subsubsection{Imunoensaio cromatográfico}

O diagnóstico precoce da enfermidade é essencial para um bom prognóstico e melhora do animal. Quando nos deparamos com animais que estejam com sinais inespecíficos da moléstia, porém existe a suspeita, o diagnóstico precoce e mais acessível possível seria o ideal, e recentemente está sendo usado um kit de imunoensaio cromatográfico (teste rápido), que detecta se existe a presença do vírus no organismo 
do animal, usando amostras biológicas como, urina, líquor, soro, plasma e até mesmo secreções oculares. Este é um excelente método para detecção de animais que estão em fase de viremia (CURTI et al.,2012).

\subsection{Achado Anatomopatológicos}

Os cães acometidos pela infecção, podem apresentar na necropsia secreções oculares serosas, catarrais ou até mesmo mucopurulentas e secreções nasais. As mudanças macroscópicas causadas pelo vírus são na maioria das vezes inconclusivas, mesmo o animal apresentando sinais graves da doença. Em algumas situações, observase a atrofia do timo, que já foi considerado um achado patognomônico desta enfermidade, contudo, não é um achado frequente, principalmente em casos mais brandos da infecção (SONNE, 2009).

Hiperqueratose dos coxins digitais, pústulas abdominais, e secreção ceruminosa no conduto auditivo externo, foram alguns dos achados durante a necropsia de cães, em uma pesquisa executada por Sonne et al., no ano de 2008. Os pulmões podem apresentar-se colabados, edemaciados e ainda avermelhados. A mucosa estomacal também pode se apresentar hiperêmica (SONNE et al., 2009).

Também podemos encontrar, porém, com pouca frequência, corpúsculos de inclusão no baço, nos linfonodos mesentéricos e com maior ocorrência nas tonsilas (SONNE et al., 2009). Pneumonia intersticial, broncointesticial, e broncopneumonia supurativa, edema alveolar, corpúsculos de inclusão no epitélio de brônquios e bronquíolos são alguns dos achados na necropsia desta enfermidade (SONNE et al., 2009).

\subsection{Diagnóstico diferencial}

Segundo Curti (2012), o diagnóstico diferencial da cinomose se baseia em todas as doenças infecciosas e de caráter inflamatório e que também tenham sinais neurológicos. Dentre estas enfermidades estão, a raiva, encefalite pós vacinal, hepatite infecciosa, leptospirose, entre outras (DIAS et al., 2012). Além destas enfermidades citadas, também se destacam ainda, a parvovirose e toxoplasmose. Enfermidades de origem entérica não podem ser descartadas, como a salmonelose e pasteurelose, assim como as infecções que tem sintomas respiratórios, como os da traqueobronquite infecciosa canina, conhecida popularmente por tosse dos canis. A erliquiose canina 
também se inclui no diagnóstico diferencial por apresentar sintomatologia de origem nervosa e respiratória. Temos ainda, a hipocalcemia, que pode levar o animal a ter problemas locomotores, que se parecem com mioclonias (MONTI, 2004).

\subsection{Tratamento}

Não existe tratamentos específicos para a cinomose. 0 tratamento se baseia em terapias de suporte e sintomáticas, sempre visando a melhora imunológica do animal, e consequentemente evitando infecções secundárias (CURTI et al., 2012; SILVA et al., 2015). Para a terapêutica de suporte, são indicados alguns antibióticos de amplo aspecto, que irão combater infecções bacterianas secundarias, do trato respiratório e gastrointestinal, também se utilizam vitaminas do complexo $B$, complementos nutricionais, e eletrólitos (SANTOS, 2006). Pode-se ainda, fazer o uso de anticonvulsivantes quando necessário, e a administração de glicocorticoides pode ser eficaz para alguns animais, porém, são contraindicados para animais que estão com infecção aguda da doença (NELSON e COUTO, 2010).

No caso de diarreia e vomito, o uso de antieméticos, protetores gástricos, e imunoestimulantes, também são importantes, assim como uma boa alimentação se torna indispensável. Há ainda, algumas técnicas, que estão obtendo sucesso para a reduzir as sequelas causadas pela cinomose, como a acupuntura e a fisioterapia (FREITAS, 2017).

Corticoides também podem ser usados, com objetivo de reduzir o edema cerebral provocado pelo patógeno (GREENE e VANDEVELDE, 2012). Porém o uso desses corticoides tem suas desvantagens, pois ele leva a imunossupressão devido a resposta inflamatória, que é responsável pela retirada do agente do organismo. Assim, eles ajudam a reduzir a inflamação, mas prejudicam a defesa do animal acometido, o que aumenta o aparecimento dos sinais clínicos.

Outro medicamento que vem sendo usado é a ribavirina, que atua diretamente impedindo a replicação viral. Entretanto, mesmo considerada um importante antiviral, a ribavirina não consegue ter efeito se o vírus já se encontrar no sistema nervoso central (VIANA e TEIXEIRA 2015).

Contudo, mesmo com o tratamento de suporte, se o animal não tiver uma resposta imunológica suficiente para eliminar o vírus, grande parte da população 
acometida acaba morrendo naturalmente, ou mesmo sendo eutanasiados. Os que conseguem sobreviver, geralmente apresentam sequelas neurológicas (CURTI et al., 2012; SILVA et al., 2015). A eutanásia é indicada em casos incompatíveis com a vida, uma vez que os sinais neurológicos progridem muito rapidamente (MONTI, 2004). A outra parte da população acometida que consegue sobreviver ao vírus e se recuperar, recomenda-se o acompanhamento deste animal durante algum tempo, para evitar a progressão da enfermidade e evitando a eutanásia (PLATT e OLBY, 2004).

\subsection{Prognóstico}

O prognóstico para cinomose é considerado reservado. Visto que, vários fatores podem interferir como as manifestações clínicas apresentadas, se tem ou não presença de sinais neurológicos e a idade do animal são fatores que podem interferir na recuperação. Contudo, mesmo não existindo tratamento específico, tratar as infeç̧ões secundarias e a terapia de suporte ajudam na recuperação. Nos casos neurológicos mais graves, que apresentam incompatibilidade com a vida, se não houver recuperação do animal com o tratamento suporte, e ele apresentar sinais incompatíveis com a vida pode-se optar pela eutanásia (SHERDING e BIRCHARD, 2008).

\subsection{Profilaxia}

A vacina é a melhor forma de prevenção da enfermidade, e o não cumprimento desta ação pode aumentar cerca de cem vezes o risco da doença nos cães (MARTINS; LOPES; FRANÇA, 2009). Alguns fatores interferem diretamente nos resultados esperados pela vacinação, como imunidade do animal, se ele está com outa doença sistêmica, idade, estresse, e até mesmo a temperatura de armazenamento da vacina (PEREIRA et al., 2014).

Outras medidas de prevenção também podem ser realizadas, como: evitar o contato do animal enfermo com outros, impedindo ainda mais a disseminação viral, como também a desinfecção do local onde vive o animal é de extrema importância para a eliminação do vírus. Estas medidas devem ser adotadas em conjunto com a vacinação, que é indicada para ter seu início a contar da sexta ou oitava semana do recém-nascido, tendo intervalos de 21 dias, somando um total de 3 doses, com reforço anual. Assim, essa vacina aplicada tem obtido sucesso na prevenção da doença (MONTI et al., 2007; SILVA et al., 2015). 
Por se tratar de uma moléstia que acomete principalmente animais filhotes, a vacina se torna mais eficiente quando os títulos de anticorpos passados da mãe para o filhote estão baixos, que geralmente é com 12 semanas de idade, e é o período de mais eficiência da vacina, mas ainda, há casos em que os anticorpos maternos diminuem mais cedo do que esperado, deixando assim, os filhotes predispostos a contrair a doença (MONTI et al., 2007; SILVA et al., 2015).

Aos animais que estão na fase aguda da doença, deve-se evitar o contato com outros, pois nesta fase o animal infectado está eliminando altas cargas virais, através de suas excreções e secreções. Além disso, é de muita relevância que se use no ambiente contaminado, desinfetantes que contenham em sua composição amônia quaternária a $3 \%$, também o uso de formol $0,5 \%$ e fenol a $0,75 \%$, e entre outros, são eficazes na inativação do vírus (SANTOS., 2006).

Manter os olhos e narizes sempre limpos, visto que é característica da enfermidade, grandes descargas nestes locais, assim como, manter uma nutrição adequada e uma correta higienização do local que o animal habita, são cuidados importantes para uma boa recuperação (SILVA et al., 2015).

\section{CONSIDERAÇÕES FINAIS}

Com base nas literaturas consultadas, podemos resumir a cinomose como uma doença infecciosa grave, que fica atrás somente da raiva, quando se trata de altas mortalidades. No entanto, a realização deste trabalho possibilitou uma maior compreensão sobre esta enfermidade, destacando a importância da vacinação e prevenção, contribuindo desta forma para uma menor ocorrência da doença. $O$ trabalho ainda abordou, os principais sinais apresentados pelo cão acometido, meios de transmissão e diferentes formas de contaminação, auxiliando para o maior esclarecimento da moléstia.

Diferentes formas de diagnósticos e melhores fases da infecção para realizá-los, foram descritas. Já foi discutido por vários autores, que a presença do corpúsculo de Lentz é um achado patognomônico da doença, o que seria um ótimo método para confirmação do diagnóstico, porém, não são todos os casos que terão a presença do corpúsculo. Assim, o método mais recomendado é a RT-PCR, porém, não é 
rotineiramente o mais acessível, desta forma o imunoensaio cromatográfico (teste rápido), vem sendo o mais utilizado, por ser de fácil acesso e rápido resultado.

Por ser uma doença infecciosa grave, devido acometer o SNC dos cães, precisa ser tratada com grande responsabilidade, pois a negligência de tratamento pode causar sequelas irreparáveis, ou até mesmo levar a morte. Como já foi descrito, os cães são os principais reservatórios, sendo assim, indispensável o controle da doença nestes animais, principalmente, por meio da vacinação. O conhecimento sobre a epidemiologia da doença, é um fator importante para a conscientização de que os cães precisam ser vacinados, até mesmo os mais velhos e imunossuprimidos. É importante ressaltar também que, em locais onde vivem outros cães, o isolamento do animal doente dos sadios é um controle eficiente para evitar a disseminação das partículas virais.

Dessa forma, o presente estudo, apresentou a importância que esta enfermidade traz para a rotina clínica de pequenos, fazendo com que, haja um maior conhecimento sobre a doença, desde a correta vacinação até medidas de prevenção. Assim favorecendo na diminuição da ocorrência desta enfermidade.

\section{REFERÊNCIAS}

ALMEIDA, R. K. et al. Alterações citológicas do sangue periférico e da medula óssea de cães com cinomose. Arq. Bras. Med. Vet. Zootec., v. 61, n. 6, p. 1255- 1260, 2009

ALMEIDA, Jéssica Goulart. Ocorrência de cinomose em cães atendidos em uma clínica veterinária no município de Lagoa da Prata/MG. 2016.

AMUDE, A. M. et al. The nervous form of canine distemper. Veterinária e Zootecnia. p. 125-136, 2006.

AMUDE, A. M. et al. Clinicopathological findings in dogs with distemper encephalomyelitis presented without characteristic signs of the disease. Research in Veterinary Science. v. 1, n. 82, p. 10-15, 2007

APPEL, M. J. G. Cinomose. In: BARR, S.C.; BOWMAN, D.D. Doenças Infecciosas e Parasitárias em Cães e Gatos. Rio de Janeiro: Livraria e Editora Revinter Ltda, 2010. Cap. 23. p. 113-118.

BARBOSA, J. M; PASSOS, R. F. B. Análises dos casos de cinomose H.V. São Francisco de Assis na Faculdade Latino-americana - Anápolis-GO. In: Ensaios e Ciências: Ciências Biológicas, agrárias e da saúde. v.12, n.01, p. 139-150, nov. 2008. 
BARBOSA, T. E. et al. Avaliação laboratorial da cinomose canina - estudo retrospectivo de 25 casos no município de Araçatuba, SP. Revista de Ciências Agroveterinárias, Lages. São Paulo, 2011. p.113-118.

BEINEKE, A.C. et al. Pathogenesis and immunopathology of systemic and nervous canine Distemper. Vet. Immunol. 2009. p. 1-18.

BRAZ, G. F. Padronização e Teste da Técnica de Imunofluorescência Direta Para o Diagnóstico da Cinomose Canina, 2009. 43 f. Dissertação (mestrado) Universidade Federal de Minas Gerais, Escola de Veterinária, 2009.

CARVALHO, O. V. et al. Immunopathogenic and Neurological Mechanisms of Canine Cistemper Virus. Advances in Virology. v. 1, n. 1, p. 1-10, 2012

CURTI, M. C. et al. Avaliação de um kit de imunoensaio cromatográfico para detecção do antígeno do vírus da cinomose em cães com sinais sistêmicos ou neurológicos da doença. Semina: Ciências Agrárias. v.33, n. 6, p. 2383-2390, 2012

DIAS, M. B. M. C. et al. Cinomose canina: revisão de literatura. Medicina Veterinária. v. 6, n. 4, p.32-40, 2012.

ETTINGER, S. J.; Feldman, E. C. Tratado de medicina interna veterinária: doenças do cão e do gato. v.1, 5 ed., p.440-441. Editora Guanabara Koogan S.A. 2004.

FREITAS, Thainã Carine de. Cinomose: Relato de Caso. 2017.63f.Trabalho de Conclusão de Curso. Universidade Federal do Recôncavo da Bahia, cruz das almas Bahia,2017.

GEBARA, C. M. S. et al. Lesões Histológicas no Sistema Nervoso Central de Cães com Encefalite e Diagnóstico Molecular da Infecção Pelo Vírus da Cinomose Canina. Arq.Bras. Med. Vet. Zootec., v.56, n.2. 2004. p.168-174.

GREENE, C. E.; VANDEVELDE, M. Canine Distemper. Infectious Diseases of the dog and cat. Fourth Edition, Elsevier, St. Louis, Missouri. 2012. p. 25-42.

HEADLEY, S. A. et al. Epidemiological Features And The Neuropathological Manifestations Of Canine Distemper Virus-Inducedinfections in Brazil: A Review. Semina: Ciências Agrárias. Londrina, v.33, n.5. 2012. p.1945-1978.

HOSKINS, J. D. Doenças Virais Caninas. Tratado de medicina interna veterinária: doenças do cão e do gato. 5. Ed. Rio de Janeiro: Guanabara Koogan, 2008. v.1, cap. 88. p. 440-444.

LATHA, D. et al. Development of Recombinant Nucleocapsid Protein Based IgM-ELISA for the Early Detection of Distemper Infection in Dogs. Vet. Immunol Immunopathol. Amsterdam. v. 119, n. 15. 2007. p. 278-286. 
LITFALLA, F.; HAMZÉ, A. L.; PACHECO, A. M.; SOUZA, C. C.; RODRIGUES, C. A. L.S.; FILADELPHO, A. L.; BARIANI, M. H. Cinomose e o Processo de Desmielinização. In: Revista Científica Eletrônica de Medicina Veterinária, Garças-SP, n. 11, jul. 2008.

LÓPEZ A. 2007. Respiratory System, p.463-542. In: McGavin M.D. \& Zachary J.F. (Ed.), Pathologic Basis of Veterinary Disease. 4th ed. Mosby Elsevier, St Louis.

LÚCIO, E. C. et al. Análise Epidemiológica da Infeç̧ão Pelo Vírus da Cinomose, em Cães do Município de Garanhuns, Pernambuco, Brasil. Semina: Ciências Agrárias. v. 35, n.3, p.1323-1330, 2014.

MARTELLA, V.; ELIA, G.; BUONAVOGLIA, C. Canine Distemper Virus. Veterinary Clinics Small Animal Practice. v.38, n.4, p.787-797, 2008.

MANGIA, S.H. Tratamento Experimental de Cães Naturalmente Infectados com o Vírus da Cinomose na Fase Neurológica Com o Uso de Ribavirina e Dimetil-Sufóxido (DMSO). 186 f. Botucatu, 2008. Dissertação (Mestrado) - Faculdade de Medicina Veterinária e Zootecnia, Universidade Estadual Paulista Júlio de Mesquita Filho. 2008.

MEGID, J; RIBEIRO, M.G; PAES, A.C. Doenças infecciosas em animais de produção e de companhia. 1a ed. Rio de Janeiro: Roca, 2016, p.561-577.

MARTINS, D. B.; LOPES, S. T. D. A.; FRANÇA, R. T. Cinomose Canina: Revisão de Literatura. Acta Veterinaria Brasilica, v.3, n.2, p.68-76, 2009.

MELLO, F. C.; AMARAI, G. A. C.; RODRIGUES, C. F. M.; PINTO, E. A. T.; Lot, R. F. E. Aspectos Clinicopatológicos da Cinomose em Cães. In: Revista cientifica eletrônica de Medicina Veterinária, Garça - SP, Jan 2008.

MONTI, F. S. Anticorpos Contra o Vírus da Cinomose em Cães Vacinados em Diferentes Estabelecimentos da Área Urbana do Município de Viçosa/MG. 67 f. Tese (Mestrado em Medicina Veterinária) - Universidade Federal de Viçosa, Minas Gerais. 2004

MONTI, F. S. et al. Anticorpos Contra o Vírus da Cinomose de Cães Vacinados em Diferentes Estabelecimentos. Ceres. 2007. v.54. n.311. p.14-19.

NASCIMENTO, D. N. S. Cinomose Canina - Revisão de Literatura. 34 p. Trabalho de especialização em clínica médica de pequenos animais - Universidade Federal Rural do Semi Árido - UFERSA, Belém - Pará. 2009.

NEGRÃO, F.J. et al. Perfil de Restrição de um Fragmento do Gene da Hemaglutinina Amplificado Pela RT-PCR a Partir de Estirpes Vacinais e Selvagens do Vírus da 
Cinomose Canina. Arquivo Brasileiro de Medicina Veterinária e Zootecnia, v.58, n.6, Belo Horizonte, 2006.

NEGRÃO, F. J. et al. Avaliação da Urina e de Leucócitos Como Amostras Biológicas Para a Detecção Ante Mortem do Vírus da Cinomose Canina por RT-PCR em Cães Naturalmente Infectados. Arq. Bras. Med. Vet. Zootec. v.59, n.1. 2007. p. 253257.

NELSON, R. W.; COUTO, C. G. Medicina Interna de Pequenos Animais. Rio de Janeiro: Elsevier, 2010. p.1441.

NONINO, R. G. et al. Detecção Molecular e Análise llogenética do Gene H de Amostras do Vírus da Cinomose Canina em Circulação no Município de Campinas, São Paulo. Pesq. Vet. Bras. v. 32, n. 1. 2012. p. 72-77.

NORRIS, J. M. et al. Canine distemper: re-emergence of an old enemy. Aust. Vet. Journal. v. 84. 2006. p. 362-363.

OLIVEIRA, A. C. et al. Cinomose Canina - Relato de Caso. Revista cientifica eletrônica de Medicina Veterinária. Garça - SP, n.12, p.2-5, jan.2009.

ORSINI, H.; BONDAN, E. F. Patogenia das Lesões do Sistema Nervoso Central (SNC) na Cinomose Canina. Clínica Veterinária: Revista de educação continuada do clínico veterinário de pequenos animais, São Paulo, n.74, p.28-31, 2008.

PEREIRA et al. Aspectos Gerais da Cinomose. Enciclopédia Biosfera, Centro Científico Conhecer, Goiânia, v.10, n.18, p. 427-441, jul. 2014.

PLATT, S. R.; OLBY, N. J. Neurological Emergencies. Manual of Canine and Feline Neurology. England: BSAVA, 2004, cap.19, p.320-336.

QUINN, P. J.; et al. Microbiologia Veterinária e Doenças Infecciosas. Porto Alegre: Artmed, p. 375-376, 2005.

RIBEIRO, V. M.; TORRES, B. B. J. Nova Abordagem da Epilepsia Canina. Centervet, agosto 11, 2014. Disponível em: < http://centervet1.blogspot.com/2014/08/novaabordagem-da-epilepsia-canina.html >. Acesso em: 07 mai.2019.

SANTOS, B. M. dos. Cinomose Canina: Revisão de Literatura. 2006. 18 f. Dissertação (Pósgraduação em clínica médica e cirúrgica de pequenos animais) - Universidade Castelo Branco, Goiânia, 2006.

SAWATSKY, B. et al. Canine Distemper Virus. The Biology of Paramyxoviruses. Caister Academic Press. Norfolk. 2011. p. 275-291.

SILVA, L.H. Queiroz da; MORINISHI, C.K.; NUNES, C.M. Diagnóstico Diferencial Entre a Raiva e a Cinomose Canina em Amostras de Cérebro de Cães Examinadas no 
Período de 1998 a 2001 na Região de Araçatuba, SP, Brasil. Arquivos do Instituto Biológico, v.71, n.3, p.317-321,2004.

SILVA, I. N. G. et al. Perfil Hematológico e Avaliação Eletroforética das Proteínas Séricas de Cães com Cinomose. Arquivo brasileiro de medicina veterinária e zootecnia. v. 57 , n. 1. 2005. p. 136-139.

SILVA, et al. Aspectos Clínicopatologicos de 620 Casos Neurológicos Cinomose em Cães. Pesq. Vet. Bras. v. 27, n. 5. 2007 p. 215-220.

SILVA, M.C. et al. Neuropatologia da Cinomose Canina: 70 Casos (2005-2008). Pesq. Vet. Bras. v. 29, n. 8. 2009. p. 643-652.

SILVA A.P. et al. Aspectos Moleculares do Vírus da Cinomose Canina e Seus Impactos na Epidemiologia da Infecção na América do sul. Revista CFMV - Conselho Federal de Medicina Veterinária. 2015. v.21, n.66, p. 72-77.

SHERDING, R. G.; BIRCHARD, S. J. Manual Saunders - Clínica de Pequenos Animais. São Paulo: Roca, 2008, p.1591.

SONNE, L. et al. Achados Patológicos e Imuno-Histoquímicos em Cães Infectados Naturalmente Pelo Vírus da Cinomose Canina. Pesquisa Veterinária Brasileira. 2009. p.143-149.

VIANA, K. F.; TEIXEIRA, N. S. Ribavirina e Fase Nervosa da Cinomose: Cura Clínica, Mas Não Esterilizante - Relato de Dois Casos. Rev. Bras. Med. Vet. 2015. v.37, n.1, p. 29-32. 


\section{CAPÍTULO VI}

\section{COINFECÇÃO POR HEPATOZOON SP. E DIROFILARIA IMMITIS EM CÃES}

DDI: 10.51859/amplla.pdi443.1121-6

Thaynara Souza Moreira ${ }^{1}$ Juliana Bruno Borges Souza ${ }^{1}$ Karla Irigaray Nogueira Borges ${ }^{2}$ Ísis Assis Braga ${ }^{2}$ Eric Mateus Nascimento de Paula ${ }^{2}$

\footnotetext{
${ }^{1}$ Médica Veterinária Autônoma. Egressa do Curso de Medicina Veterinária do Centro Universitário de Mineiros UNIFIMES

${ }^{2}$ Docente do Curso de Medicina Veterinária do Centro Universitário de Mineiros - UNIFIMES.
}

\section{INTRODUÇÃO}

Na rotina clínica veterinária de pequenos animais, é frequente o acometimento de cães e gatos por hemoparasitoses, como erliquiose, babesiose, hepatozoonose e, também dirofilariose. Porém, essas enfermidades são de difícil diagnóstico clínico, pois apresentam sinais clínicos inespecíficos e semelhantes entre si, como febre, inapetência e anorexia, além de achados hematológicos de anemia e trombocitopenia. Exames complementares são necessários para auxiliar na identificação do agente etiológico que está parasitando o animal, direcionando para um tratamento eficaz e posterior controle dos vetores que carreiam estes parasitas (LEAL et al., 2015).

A transmissão de doenças parasitárias para os animais domésticos, pode ocorrer de forma horizontal ou vertical, sendo que, a primeira se divide em direta e indireta. $\mathrm{Na}$ transmissão horizontal direta há um contato próximo do agente e hospedeiro, enquanto na indireta há a participação de objetos inanimados ou vetores, que são os responsáveis por carrear o agente infeccioso até um hospedeiro. A atuação do vetor pode ser de forma mecânica, em que são apenas os carreadores do agente, ou de forma biológica, participando obrigatoriamente do processo de transmissão de enfermidades (MONTEIRO, 2017). 
A duração e gravidade da infecção irá depender da interação agente-hospedeiro, ou seja, da virulência do parasita e do sistema imune do animal. Em alguns casos, o hospedeiro pode ser um portador do agente, se tornando uma fonte de infeç̧ão para outros animais, dificultando o controle das parasitoses, além de adiar o tratamento contra o parasita, podendo deixar o animal suscetível à outras infecções (MEGID et al., 2016).

Alguns parasitas são oportunistas, desenvolvem-se quando há uma imunossupressão causada por outras enfermidades, como é o caso do Hepatozoon sp., que causa uma infecção subclínica até a manifestação de outras doenças que causam imunossupressão. A hepatozoonose geralmente é concomitante com infecção por Ehrlichia canis e Babesia canis, sendo o carrapato marrom o vetor em comum entre si, facilitando essa coinfeç̧ão, além de outros hemoparasitas. (ANTUNES et al., 2015; CONCEIÇÃO, 2017).

Segundo Cox (2001) quando o animal já está infectado com algum parasita que Ihe causa imunodepressão, qualquer outra infecção que se instalar no hospedeiro poderá se expressar tanto de uma forma mais virulenta ou patogênica, quanto não ser influenciada pela imunodeficiência do animal e se expressar de forma menos patogênica, sendo essa gravidade induzida pelo intervalo de aquisição das infecções e dos agentes envolvidos. As infeç̧ões concomitantes podem dificultar o tratamento de tais enfermidades, já que um medicamento indicado para certo agente etiológico, pode favorecer o desenvolvimento do outro que está presente (LLOIDY, 2010).

Desta forma, dentre os parasitos que são transmitidas por vetores e acometem os cães e que são passíveis de ocorrerem em coinfecção, destaca-se o Hepatozoon sp. e, que é transmitida pelo carrapato Rhipicephalus sanguineus, e a Dirofilaria immitis, transmitida por mosquitos hematófagos (RODRIGUES et al., 2019; SANTOS et al., 2019).

\section{REVISÃO DE LITERATURA}

\subsection{Hepatozoonose Canina}

\subsubsection{Definição}

A hepatozoonose canina é uma infecção causada pelo protozoário Hepatozoon sp., em cães mais especificamente, o H. canis e H. americanum, e transmitido por 
artrópodes. Apesar do nome fazer referência ao fígado, não é o principal órgão afetado, os leucócitos que são mais acometidos. A infecção irá se instalar no animal, após a ingestão do vetor, que na maioria dos casos é o carrapato, contendo oocitos maduros (GRRENE, 2015).

\subsubsection{Agente etiológico}

O protozoário Hepatozoon sp. pertence ao filo Apicomplexa, subordem Adeleorina e família Hepatozoidae. São mais de 300 espécies existentes, mas apenas duas são consideradas patogênicas para cães e gatos, o H. canis e o H americanum. No Brasil há relatos de canídeos domésticos que foram parasitados pelo $\mathrm{H}$. americanum, porém a espécie mais relatada é o $\mathrm{H}$. canis, através da identificação dos gametócitos, achados citológicos e moleculares (MEGID et al, 2016).

Além dos mamíferos, outras espécies de Hepatozoon sp., podem infectar pássaros, répteis e anfíbios por todos os continentes. Os hospedeiros definitivos invertebrados podem ser carrapatos, ácaros, mosquitos, pulgas, flebotomíneos, piolhos e sanguessugas, nos quais o parasito irá se desenvolver sexualmente e evoluir para o estágio esporogonia e, posteriormente, gametogonia em seu hospedeiro vertebrado definitivo (BANETH et al, 2007).

Na América do Sul a espécie predominante é o H. canis, sendo transmitido pelo carrapato Rhipicephalus sanguineus e Amblyomma ovale, e na América do Norte, predomina-se o $\mathrm{H}$. Americanum, transmitido pelo carrapato Amblyomma maculatum (NELSON; COUTO, 2015).

\subsubsection{Epidemiologia}

O protozoário $H$. canis foi descrito primeiramente na Índia por causar a hepatozoonose canina e, posteriormente, em outros países da Europa, Ásia, África e América Latina, estando associado tanto a sinais clínicos brandos quando há baixa parasitemia, quanto a risco de morte do animal em altas parasitemias. Na América do Norte, o H. Americanum é o responsável pela ocorrência de uma doença clínica severa em cães, podendo levá-los à morte (FORLANO, et al., 2007).

Na América do Sul, o H. canis já foi diagnosticado em alguns países, como Argentina, Colômbia e Brasil. A maioria dos estados brasileiros já identificou a ocorrência da hepatozoonose canina, como por exemplo, Distrito Federal, Goiás Mato Grosso do 
Sul, Minas Gerais, Espírito Santo, Rio de Janeiro, São Paulo, Rio Grande do Sul e Pernambuco. Apesar disto, há uma baixa prevalência do H. canis no país, tendo maior ocorrência em cães de zona rural e que apresentem coinfecções por outros parasitos (O'DWYER, L. H., 2011).

A infestação de carrapatos está intimamente relacionada com a ocorrência da hepatozoonose, principalmente de Rhipicephalus sanguineus, mais comum em zona urbana e, em região rural, o Amblyomma ovale. Além disto, a convivência com outros cães facilita a transmissão do ectoparasita entre os animais. A hepatozoonose pode acometer cães de todas as idades, mas há uma maior ocorrência em animais jovens por terem um sistema imune ainda em desenvolvimento, deixando-os mais expostos às infecções (GOMES, P. V. et al., 2010).

A infecção tem maior ocorrência em meses mais quentes do ano, estando associada à presença de seu vetor nessas épocas. Porém, mesmo em épocas mais frias, em que a presença do vetor é mínima, pode ocorrer a detecção da doença, estando relacionada com a persistência crônica da doença em alguns cães. Além disto, um sistema imune que esteja comprometido, aumenta a suscetibilidade para a ocorrência da hepatozoonose e sintomatologia de infecções crônicas. É comum a presença de coinfecções por Ehrlichia spp. e Babesia spp. (BORGES, C. E. F. et al., 2015).

A transmissão ocorre quando o animal ingere o carrapato contendo oocistos maduros. Além disso, pode também ocorrer a transmissão vertical da infecção através de cadelas infectadas. Hospedeiros paratênicos como coelhos e ratos possuem cistozoítas em seus tecidos e, após a predação, os cães desenvolvem a infecção. Cães que vivem em áreas rurais têm maior predisposição a se infectar, já que estão próximos de animais silvestres, que são reservatórios da doença (SANTOS et al., 2019).

Após a liberação dos esporozoítos no trato digestivo do animal, os mesmos atravessam a parede intestinal e se disseminam via corrente sanguínea ou linfática, com destino à medula óssea, baço e linfonodos, nos quais irá ocorrer a merogonia. Irá surgir dois tipos de merontes, os macromerontes e os micromerontes. Os macromerontes irão conter de dois a quatro macromerozoítos, enquanto os micromerontes conterão de 20 a 30 micromerozoítos. Os macromerozoítos irão invadir tecidos e iniciar uma segunda merogonia, enquanto os micromerozoítos irão invadir neutrófilos e monócitos para 
sofrer uma gametogonia e dar origem aos gamontes circulantes, os quais serão ingeridos durante o repasto sanguíneo do vetor, o infectando (DEMONER, L. C., 2011).

\subsubsection{Patogenia}

A presença de coinfecções e o estado imunológico do animal irão influenciar o desenvolvimento da patogenia do $\mathrm{H}$. canis ou reativar infecções existentes. No momento da ruptura do meronte, ocorre uma intensa resposta inflamatória aumentando os leucócitos no local, que irão ser invadidos pelos gamontes. A lesões locais irão evoluir para granulomas vasculares, nos quais os merozoítos irão penetrar nos leucócitos e circular na corrente sanguínea (BANETH et al, 2007; GREENE, 2015; MEGID et al., 2016).

Ao ingerir o carrapato infectado, os esporozoítos ao atingirão o trato digestivo do cão e irão para o sistema porta, se disseminando para o fígado, pulmões, baço, medula óssea, rins e linfonodos, podendo levar â hepatite, pneumonia e glomerulonefrite (LASTA, 2008).

Os gametócitos possuem a capacidade de utilizar a mieloperoxidase dos neutrófilos para sua maturação, além do peróxido de hidrogênio, que é um substrato da mieloperoxidase. Ao inibir a mieloperoxidase, ocorre a inibição do ácido hipocloroso, causando uma diminuição da função fagocítica dos neutrófilos parasitados, deixando os animais suscetíveis a infecções sistêmicas e bacterianas, além de diminuir a capacidade de destruir o H. canis (IBRAHIM et al, 1989).

Animais que possuem baixa quantidade de gametócitos circulantes nas células sanguíneas, poderão ser assintomáticos, já que a gravidade dos sinais clínicos e a taxa de parasitemia estão correlacionados (MUNDIM et al., 2008). Além disso, a dificuldade de localização dos gametócitos durante os exames hematológicos, pode ser devido ao encistamento dos mesmos no momento da coleta do sangue ou, ainda, ocorrer a perda dos gametócitos durante os procedimentos laboratoriais (PALUDO et al., 2003).

\subsubsection{Sinais Clínicos}

A infecção por H. canis geralmente é assintomática podendo ocorrer de forma subclínica. Na maioria dos casos, ocorre coinfecção com Babesia vogeli ou Erlichia canis aumentando a demonstração de sinais clínicos. A sintomatologia é inespecífica, sendo comum observar mucosas hipocoradas, febre e anorexia (O'DWYER, 2011). 
Os sinais clínicos que também podem ser encontrados são apatia, tremores musculares, prostração, dor, vômito, diarreia, linfadenopatia, ataxia dos membros posteriores e dificuldade em manter-se em estação (AGUIAR et al, 2004; HONÓRIO et al, 2017).

Em um estudo feito por Baneth et al. (2007), observou-se o aumento da temperatura corporal dos cães infectados experimentalmente, por volta dos 25 dias pós infecção, variando de $39,9^{\circ} \mathrm{C}$ a $41^{\circ} \mathrm{C}$. Alguns cães apresentaram hiperestasia dos membros aos 26 dias pós infecção, sendo acompanhada por febre. Dificuldade de locomoção foi observada em um cão do experimento, e após 10 dias ele voltou ao seu desempenho normal. Outros dois cães apresentaram dificuldade em locomover os membros pélvicos e assumiram posição de decúbito esternal.

\subsubsection{Diagnóstico}

No histórico do animal geralmente há relatos de acesso ou criação em zona rural ou periurbana e, também, a presença de coinfecções imunodepressoras. O esfregaço sanguíneo corado com Giemsa, Panótico ou colorações do tipo Romanowsky, permite a visualização de gamontes em neutrófilos e monócitos. No hemograma pode haver presença de anemia normocítica, normocrômica e não regenerativa; leucocitose por neutrofilia e monocitose; pode haver basofilia e eosinofilia e, em casos de coinfecções com outro hemoparasita, pode haver trombocitopenia acentuada. Diagnóstico sorológico tem sido indicado por ter maior sensibilidade, como a imunofluorescência indireta, mas pode ocorrer falso-positivo ou falso-negativo dependendo da fase da infecção. A reação em cadeia pela polimerase (PCR) tem alta sensibilidade e especificidade na detecção do parasita (MEGID et al, 2016).

Em aspirado de medula óssea, é possível observar vários estágios dos esquizontes, podendo assim, diagnosticar o H. canis em cães com baixa parasitemia. Além disso, a avaliação da capa leucocitária é mais sensível do que avaliar apenas o esfregaço sanguíneo. Quando não ocorre a detecção dos gamontes pelo PCR ou esfregaço sanguíneo, não se pode afirmar que o animal está livre da infecção, já que uma baixa parasitemia dificulta a visualização dos gamontes, que não se encontram circulantes no sangue. Se o animal for exposto a outra infecção ou ter uma queda na 
imunidade, poderá ocorrer uma reativação dos esquizontes teciduais e ressurgimento dos sinais clínicos (O’DWYER, 2011).

O pico de parasitemia geralmente ocorre por volta dos 50 dias pós infecção, elevando a taxa de sucesso no diagnóstico, já que haverá mais gamontes circulantes e visíveis no esfregaço sanguíneo. Na necropsia, é possível observar merontes de $\mathrm{H}$. canis no baço, fígado medula óssea e periósteo, degeneração miocárdica e, podendo também, haver uma proliferação óssea periosteal (BANETH et al., 2007).

A detecção de anticorpos lgM é possível a partir do décimo sexto dia pós infecção, e de IgG após 22 dias da presença do parasito, através do teste de Imunofluorescência Indireta em cães com baixa parasitemia ou recém infectados (O’DWYER, 2011).

\subsubsection{Tratamento}

Não há registros de medicamentos específicos para o tratamento da hepatozoonose, mas são utilizadas algumas associações de fármacos, a fim de destruir o parasito. O dipropionato de imidocarb (5mg a $6 \mathrm{mg} / \mathrm{kg}$, IM ou SC) com uma ou duas aplicações com intervalo de 14 dias, associado com doxiciclina (10mg/kg/dia, VO) por 21 dias, apresentam bons resultados. A combinação de toltrazurila (10mg/kg/dia, VO) por 5 dias e, após, $5 \mathrm{mg} / \mathrm{kg} / \mathrm{dia}$, VO por mais 10 dias com trimetoprima/sulfonamida $(15 \mathrm{mg} / \mathrm{kg}, \mathrm{VO}) 2$ vezes ao dia, por 30 dias, tem se mostrado eficiente (GREENE, 2015). O prognóstico é bom a reservado dependendo da parasitemia (MEGID et al, 2016).

\subsubsection{Controle e Prevenção}

A melhor forma de prevenção da hepatozoonose, é o controle de carrapatos, já que são estes os principais responsáveis pela transmissão do Hepatozoon sp (NELSON; COUTO, 2015). Existem no mercado diversas apresentações de carrapaticidas para o uso em cães, como por exemplo, comprimidos, coleiras e spot on, devendo ser escolhida a melhor opção para cada animal. Dentre os princípios ativos mais encontrados estão, deltametrina, afoxolaner, fipronil, fluralaner, sarolane, selamectina e imidacloprida, com tempo de proteção variáveis, indo de 30 dias à 8 meses (ZARDO; PEREIRA, 2019). 


\subsection{Dirofilariose}

\subsubsection{Definição}

A dirofilariose, ou verme do coração, como é conhecida, é uma infecção crônica causada pelo verme Dirofilaria immitis, que é transmitido por mosquitos hematófagos contendo suas larvas, que irão migrar para o coração. Sua ocorrência é comum em cidades litorâneas ou zonas rurais e periurbanas (NAGASHIMA et al, 2009).

\subsubsection{Etiologia}

O agente etiológico da dirofilariose é o nematoide filariano parasito Dirofilaria immitis, pertencente a superfamília Filarioidea, família Filariidae, subfamília Dirofilarinae. O gênero Dirofilaria apresenta dois subgêneros, Dirofilaria (D. immitis) e Nochtiella (D. repens). A D. immitis, acomete o sistema circulatório, linfático, cavidade peritoneal ou mesentério. Além do filarídeo $D$. immitis, há também o $D$. repens, que provoca a dirofilariose subcutânea. (SILVA; LANGONI, 2008; GREENE, 2015; RAMOS et al, 2016).

As microfilárias da D. immitis possuem movimentos lentos, de forma serpentiforme. Medem cerca de $298 \mu \mathrm{m}$ de comprimento e 7,3 $\mu \mathrm{m}$ de largura, com sua extremidade posterior reta e anterior em formato oval (BRITO et al., 2001).

\subsubsection{Epidemiologia}

Os hospedeiros intermediários do parasita D. immitis, são os mosquitos dos gêneros Aedes spp., Anopheles spp. e Culex spp. O principal hospedeiro definitivo é o cão doméstico e canídeos selvagens, raramente acomete o gato e o ser humano. Além disso, o cão também é um reservatório do D. immitis; Segundo Labarthe et al (2014)., no Brasil as regiões com matas e litorâneas possuem maiores taxas de infecção do D. Immitis, relacionado com a presença do vetor que vivem na natureza e preferem temperaturas acima de $14^{\circ} \mathrm{C}$.

A ocorrência da dirofilariose irá variar com a localização geográfica, a população canina suscetível, presença dos vetores, quantidade de animais infectados, idade, manejo e estilo de vida dos cães. Locais com maior umidade e áreas verdes, como litorais ou região com lagos, favorecem o desenvolvimento e reprodução dos culicídeos se comparado com regiões centrais que possuem um clima mais seco (BRITO et al., 2001; TRANCOSO et al., 2020). 
As fêmeas dos mosquitos ingerem as larvas (L1) quando se alimentam em um cão infectado e, então, no vetor as larvas mudam de L1 para L2 e, em seguida, para L3, que é a forma infectante. Quando o mosquito vai se alimentar em um cão, deposita as larvas (L3) junto com a saliva na pele do animal. As larvas penetram no tecido subcutâneo e permanecem por dois meses, até fazer a muda para L4 e, então, entra na circulação sanguínea. Enquanto se deslocam para o coração pela circulação, as larvas fazem a muda para L5 ou adultos imaturos, que penetram em veias periféricas até chegarem no coração e, deste, para as artérias pulmonares, em cerca de 70 dias pós inoculação. Após atingirem o pulmão, a pressão do fluxo sanguíneo conduz os adultos imaturos para arteríolas pulmonares, aumentam de tamanho e se alojam nas grandes artérias até se tornarem parasitas adultos maduros e, então, ocorre a cópula e são geradas novas microfilárias. À medida que a carga parasitária aumenta, os parasitas se alojam no ventrículo direito. Todo o ciclo leva de 7 a 9 meses para se completar, e os parasitas adultos sobrevivem por vários anos e as microfilárias até dois anos e meio (SILVA; LANGONI, 2008; NAGASHIMA et al., 2009; NELSON et al., 2014).

\subsubsection{Patogenia}

Primeiramente, as dirofilárias irão causar danos nas artérias pulmonares e aos pulmões. Vermes adultos causarão danos no endotélio de vasos pulmonares, proliferação vilosa e infiltrados neutrofilicos nas paredes vasculares. A quantidade de vermes irá influenciar na gravidade da doença, assim como, o nível de atividade do animal, quanto mais o animal for submetido a exercícios, maior será a resistência vascular pulmonar e irão desenvolver a doença clínica mais precocemente. As alterações clínicas vistas no animal acometido, são primeiramente resultado das dirofilárias mortas, as quais se decompõem e seus fragmentos se alojam na arteríola pulmonar distal e capilares dos lobos pulmonares caudais, causando bloqueio do fluxo sanguíneo. Os fragmentos dos vermes, juntamente com a inflamação provocada e agregação plaquetária, irão causar um tromboembolismo pulmonar e, com o aumento do fluxo sanguíneo os capilares frágeis se rompem, causando hemorragia e fibrose. A síndrome caval é consequência de grandes cargas de vermes preenchendo toda a artéria pulmonar e estendendo para o ventrículo e átrio direito (GREENE, 2015). 


\subsubsection{Sinais Clínicos}

Os vermes adultos irão causar uma lesão vascular progressiva que, quanto mais agressiva, irá levar à um aumento do ventrículo direito, e a circulação não será capaz de compensar essa alteração, levando à insuficiência cardíaca (TRANCOSO et al., 2020). Em fases moderadas, há a intolerância ao exercício, tosse crônica, queda do apetite, emaciação e presença de sons anormais na ausculta dos pulmões. Nos casos graves há taquipneia, falência congestiva cardíaca direita, ascite, esplenomegalia, hepatomegalia, síncope, edema subcutâneo, tromboembolismo pulmonar e síndrome caval (SILVA; LANGONI, 2008; NAGASHIMA et al., 2009).

\subsubsection{Diagnóstico}

Alterações no hemograma que não são indicativas de infecção pelas dirofilárias, incluem eosinofilia, basofilia, neutrofilia, anemia arregenerativa e trombocitopenia. A detecção de microfilárias por microscopia é feito por sangue com anticoagulante por técnicas de hemoconcentração com filtro Millipore ou por centrifugação, pelo método de Knott., porém em $80 \%$ dos casos não é possível detectar as microfilárias. Testes sorológicos são mais específicos e sensíveis, sendo indicados como método de triagem primária em cães, e estão disponíveis em kits comerciais baseados em imunoensaio enzimático. Já a radiografia é eficaz para identificar a gravidade da doença cardiopulmonar e a visualização do parasita pela ultrassonografia confirma o diagnóstico (SILVA; LANGONI, 2008; GREENE, 2015).

No método de Knott Modificado, é possível detectar e identificar as microfilárias através da concentração delas, em objetivas de 100x ou 400x. No teste da Gota Espessa, na qual é adicionada uma gota de sangue entre a lâmina e lamínula para posterior visualização no microscópio, é possível observar as microfilárias em movimentos entre os eritrócitos na objetiva de 10x. Os testes sorológicos identificam ao menos uma forma adulta de fêmea, sendo o exame preferencial para a detecção de infecções "ocultas", as quais não há microfilárias circulantes, apenas formas adultas, porém não existem testes que sejam capazes de identificar machos em formas adultas. Sendo assim, é possível que haja um falso-negativo em casos em que as fêmeas são imaturas e que apenas parasitos machos estejam presentes (AHS, 2014). 


\subsubsection{Tratamento}

Para eliminar vermes adultos, faz-se o uso da melarsomina $(2,5 \mathrm{mg} / \mathrm{kg}$, IM) em duas doses com intervalo de 24 horas ou aplicação de três doses, sendo uma aplicação e, após um mês, aplica-se as outras duas doses com o intervalo de 24 horas, realizandose a restrição de atividades físicas, que é essencial para o paciente durante a administração do tratamento, já que a morte dos vermes adultos acarreta um tromboembolismo pulmonar (AHS, 2014). O uso das lactonas macrocílicas, como ivermectina e moxidectina, são usadas para eliminar as microfilárias e, em conjunto com a doxiciclina, fragiliza os nematoides adultos. O uso de esteroides ajuda a controlar os sinais clínicos do tromboembolismo pulmonar. (NELSON et al., 2014).

Em cães com síndrome da veia cava, é necessário realizar procedimento cirúrgico para a retirada dos vermes, além de ser indicado para cães que possuem altas cargas parasitárias e que possuem um risco maior de complicações no tratamento com adulticidas. É recomendado realizar um ecocardiograma para observar se os helmintos estão em locais acessíveis antes do procedimento cirúrgico (ESDA, 2017). A remoção cirúrgica dos vermes adultos do átrio direito e válvula tricúspide, pode ser realizada através de uma sedação e introdução de pinças flexíveis ou de resgate na veia jugular externa. Através de uma incisão na veia jugular, é introduzida a pinça flexível guiadas com auxílio fluoroscópico, e são removidos os vermes adultos (AHS, 2014).

\subsubsection{Controle e Prevenção}

Lactonas macrocílicas podem ser usadas por via oral como forma de prevenção a cada 30 dias a partir de 7 semanas de vida do animal. Além disso, há o uso da moxidectina injetável, com repetição a cada 12 meses e uso de piretróides via tópica para prevenir picadas de mosquitos vetores (ESDA, 2017).

O controle do vetor também é de extrema importância na prevenção da dirofilariose. Ações como não deixar água parada, saneamento básico, evitar acúmulo de lixos e matéria orgânica são responsáveis por evitar a reprodução dos mosquitos. Além de que, evitar passeios crepusculares ou ao amanhecer, e utilizar repelentes tópicos, irá prevenir a aproximação dos vetores e a consequente infecção (VIEIRA et al., 2020). 


\section{REFERÊNCIAS}

AGUIAR, D. M. et al. Hepatozoonose canina: achados clínico-epidemiológicos em três casos. Arquivo Brasileiro de Medicina Veterinária e Zootecnia, v. 56, n. 3, p. 411413, 2004.

AHS (American Heartworm Society). Current Canine Guidelines for the Prevention, Diagnosis, and Management of Heartworm (Dirofilaria immitis) Infection in Dogs, 2014.

ALBERIGI, B. et al. Use of Slow-Release In jectable Moxidectin for Treatment of Dirofilaria immitis Infection During Pregnancy. Frontiers in Veterinary Science. v. 6, n. 440, 2020.

ANTUNES, T. R. et al. Aspectos hematológicos e epidemiológicos de cães naturalmente infectados por Hepatozoon sp. no município de Campo Grande, Mato Grosso do Sul, Brasil. Acta Veterinaria Brasilica, v. 9, n. 3, p. 234-238, 2015.

BANETH, G.; SAMISH, M.; SHKAP, V. Life cycle of hepatozoon canis (Apicomplexa: Adeleorina: Hepatozoidae) in the tick Rhipicephalus sanguineus an domestic dog (Canis familiaris). Journal of Parasitology. v. 93, n. 2, p. 283-299, 2007.

BORGES, C. E. F. et al. Alterações hematológicas em cães infectados pelo Hepatozoon canis. Revista de Educação Continuada em Medicina Veterinária e Zootecnia do CRMV-SP. São Paulo:Conselho Regional de Medicina Veterinária, v. 13, n. 3, p. 6 $-11,2015$.

BRITO, A. C. et al. Prevalência da filariose canina causada por Dirofilaria immitis e Dipetalonemare conditum em Maceió, Alagoas, Brasil. Caderno de Saúde Pública. Rio de Janeiro, v. 17, n. 6, p. 1497-1504, 2001,

CONCEIÇÃO, L. A. V. Coinfecção por Hepatozoon canis, Ehrlichia canis e Babesia canis vogeli no Brasil. 2017. Trabalho de Conclusão de Curso (Programa de Residência Uniprofissional em Medicina Veterinária) - Universidade Federal de Mato Grosso, Cuiabá, 2017.

COX, F. E. G. Concomitant infections parasites na immune responses. Parasitology, v. 122, p. 23-38, 2001.

DEMONER, L. C. Infecção experimental de Amblyomma cajennense, Amblyomma ovale e Rhipicephalus sanguineus (Acari: ixodidae) com Hepatozoon canis (Apicomplexa: hepatozoidae).2011. Dissertação (Obtenção do título de Mestre) - Universidade Estadual Paulista,Botucatu, 2011.

DUARTE, M. D. A. M. Infecção por agentes de doenças caninas transmitidas por vetores em cães de caça no Concelho de Loures. 2016. Dissertação (Mestrado Integrado 
em Medicina Veterinária) - Faculdade de Medicina Veterinária, Universidade de Lisboa, Lisboa, 2016.

ESDA (European Society of Dirofilariosis and Angiostrongylosis). Guidelines for clinical management of canine heartworm disease, 2017.

FORLANO, M. D. et al. Molecular characterization of Hepatozoon sp. From Braziliandog sand its phylogenetic relationship with other Hepatozoon spp. Veterinary Parasitology. n. 145, p. 21-30, 2007.

GOMES, P. V. et al. Occurrence of Hepatozoon sp. in dogs in the urban are a origin from a municipality in southeastern Brazil. Veterinary Parasitology. n. 174, p. 155-161, 2010.

GREENE, C. E. Doenças Infecciosas em cães e gatos. 4 Ed. Rio de Janeiro: Editora Guanabara, 2015.

HONÓRIO, T. G. A. F. et al. Infecção por Hepatozoon sp. em canino doméstico: Relato de caso. PubVet, v. 11, n. 3, p. 272-275, 2017.

IBRAHIM, N. D. G. et al. Neutrophil myeloperoxidase deficiency associated withcanine hepatozoonosis. International Journal Parasitology, v. 19, n. 8, p 915-918, 1989.

LABARTHE, N. V. et al.Updated canine infection rates for Dirofilaria immitis in areas of Brazil previous lyidentified as having a high incidence of heartworm-infected dogs. Parasites \& Vectors, v. 7, n.493, 2014.

LASTA, M. S. Hepatozoonose canina. Monografia (Certificado de Residência Médica em Patologia Clínica Veterinária) -Universidade Federal do Rio Grande do Sul, Porto Alegre, 2008.

LEAL, P. D. S. A. et al. Infecção por hematozoários nos cães domésticos atendidos em serviço de saúde animal, Rio de Janeiro, Brasil. Revista Brasileira de Medicina Veterinária, v. 37, p. 55-62, 2015.

LEMOS, J. C. M, Prevalência e distribuição de coinfecções por dirofilariose e leishmaniose canina em Portugal. 2014. Dissertação (Mestrado em Parasitologia Médica) - Instituto de Higiene e Medicina Tropical, Universidade Nova de Lisboa, Lisboa, 2014.

LLOYD. S. Environmental Influenceson Host Immunity. The Librarian-Seeley Historical Library, Acesso em maio de 2020.

MEGID, J. R.; RIBEIRO, M. G.; PAES, A. C. Doenças Infecciosas em Animais de Produção e de Companhia. 1 Ed. Rio de Janeiro: Roca, 2016.

MONTEIRO, S. G. Parasitologia na Medicina Veterinária. 2 Ed. Rio de Janeiro: Roca, 2017. 
MUNDIM, A. V. et al. Clinical an dhematological signs associated with dogs naturally infected by Hepatozoon sp. an with other hematozoa: A retrospective study in Uberlandia, Minas Gerais, Brazil. Veterinary Parasitology, v. 153, p. 3-8, 2008.

NAGASHIMA, J. C. et al. Dirofilariose. Revista Cientifica Eletrônica de Medicina Veterinária, ano VII, n. 12, 2009.

NELSON R. W., COUTO, C.G. Medicina interna de pequenos animais. 5.ed. - Rio de Janeiro: Guanabara Koogan, 2015.

NELSON, C. T. et al. Orientações atuais para Prevenção, Diagnóstico e Controle da Dirofilariose (Dirofilaria immitis) em cães. Sociedade Americana de Dirofilariose, 2014.

O'DWYER, L. H. et al. Hepatozoon canis infectionassociated withdog ticks of rural areas of Rio de Janeiro State, Brazil. Veterinary Parasitology. v. 94, p. 143-150, 2001.

O'DWYER, L. H. Brazilian canine hepatozoonosis. Revista Brasileira Parasitologia Veterinária, Jaboticabal, v. 20, n. 3, p. 181-193, 2011.

OLIVEIRA, I. N. V. et al. Perfil hematológico e bioquímico de cães infectados por Dirofilaria immitis da localidade da Ilha de Algodoal, Pará. Revista Brasileira de Medicina Veterinária. v. 35, n. 2, p. 74-80, 2013.

PALUDO, G. R.et al. Hepatozoon spp.: report of some cases in dogs in Brasília, Brazil. Veterinary Parasitology, v. 118, p. 243-248, 2003.

RAMOS, R. A. N. et al. Filarioids infecting dogs in northeastern Brazil. Veterinary Parasitology, n. 226, 2016.

RODRIGUES, R. T. G. A. et al. Presença de Leishmania sp. e Dirofilaria immitis em Tumor Venéreo Transmissível Canino cutâneo. Acta Scientiae Veterinariae. v. 47, n. 399, 2019.

SANTOS, C. M.; HALVERSON, M. M. S.; OLIVEIRA, F. P.S. Hepatozoonose canina: Relato de caso. Uniciências, v. 23, n. 1, p. 12-15, 2019.

SAVADELIS, M. D. et al. Assessment of parasitologic alfindings in heartworm-infected beagles treated with Advantage Multi ${ }^{\circledR}$ for dogs (10\% imidacloprid $+2.5 \%$ moxidectin) andoxycycline. Parasites \&Vectors. v. 10, n. 245, 2017.

SILVA, R. C.; LANGONI, H. Dirofilariose. Zoonose emergente negligenciada. Ciência Rural, 2008.

SPOLIDORIO, M. G. et al. Hepatozoon canis infecting dogs in the State of Espirito Santo,southeastern Brazil. Veterinary Parasitology. v. 163, p. 357-391, 2009. 
TRANCOSO, T. A. L. et al. Detection of Dirofilaria immitis using microscopic, serological and molecular techniques among dogs in Cabo Frio, RJ, Brazil. Brazilian Journal of Veterinary Parasitology. v. 29, n. 1, 2020.

VIEIRA, V. M. A. et al. Guia Metodológico: Capacitação profissional de Médicos Veterinários para o enfrentamento da dirofilariose canina no município da Baixada Fluminense, Rio de Janeiro. Fiocruz, 2020.

ZARDO, I. L.; PEREIRA, M. L. Segurança, eficácia e praticidade dos ectoparasiticidas para pulgas e carrapatos de cães e gatos. Investigação. v. 18, n. 4, p. 22-31, 2019. 


\section{CAPÍTULO VII}

\section{COINFECÇÕES POR HEMOPARASITAS EM CÃES}

DDI: 10.51859/amplla.pdi443.1121-7

Juliana Bruno Borges Souza ${ }^{1}$

Thaynara Souza Moreira ${ }^{1}$

Ísis Assis Braga ${ }^{2}$

Eric Mateus Nascimento de Paula ${ }^{2}$

${ }^{1}$ Médica Veterinária Autônoma. Egressa do Curso de Medicina Veterinária do Centro Universitário de Mineiros UNIFIMES

${ }^{2}$ Docente do Curso de Medicina Veterinária do Centro Universitário de Mineiros - UNIFIMES.

\section{REVISÃO DE LITERATURA}

\subsection{Definição de coinfecção}

As coinfecções referem-se à infecção de dois tipos de microrganismos diferentes simultaneamente, sendo possível encontrar em um único animal, infecção por duas ou mais formas de microrganismos (MEGID et al., 2016). Sendo assim, cães podem ser infectados por diversos agentes etiológicos, possuindo ou não o mesmo vetor, comprometendo seriamente a saúde dos mesmos (COELHO et al., 2013).

As hemoparasitoses, comumente diagnosticadas na rotina clínica de cães, são diversas vezes diagnosticas com infecções concomitantes, sendo definidas como coinfeç̧ões. Na maioria dos casos, isto influencia diretamente na patogenicidade, apresentando sinais clínicos severos, por diversas vezes, inespecíficos, dificultando o diagnóstico e comprometendo o prognóstico (FIGUEIREDO, 2011; HARRUS, WANER, 2011).

\subsection{Coinfecções em Medicina Veterinária}

Na rotina clínica veterinária, são comuns casos de coinfecções, sejam por dois ou mais diferentes agentes etiológicos (MEGID et al., 2016). Em virtude disso, alguns patógenos podem atuar comprometendo o estado de saúde do animal, favorecendo que outras infecções ocorram. Considerando o fato de o carrapato R. sanguineus ser o 
principal fator de risco, sugere-se que tenha correlação de sua ocorrência e demais doenças infecciosas (CRIVELLENTI; BORIN-CRIVELLENTI, 2015; OLIVEIRA, 2019).

\subsection{Coinfecções em cães}

Dentre alguns casos de coinfecções por hemoparasitas em cães, podemos destacar a Anaplasma platys, antigamente denominada de Ehrlichia platys, sendo uma bactéria Gram-negativa que infecta especificamente plaquetas em cães, induzindo a uma trombocitopenia cíclica infecciosa e seu provável vetor é o carrapato Rhipicephalus sanguineus, através da picada do mesmo (MONTEIRO, 2014; URQUHART et al., 1996).

Os principais sinais clínicos causados pela anaplasmose são febre, anorexia, perda de peso decorrente da falta de apetite, além de poder induzir a uma anemia normocítica normocrômica arregenerativa, hipoalbuminemia, leucopenia, hiperglobulinemia, podendo também ter a presença de macroplaquetas. O diagnóstico desta enfermidade pode ser feito através de esfregaço sanguíneo, visualizando inclusões basofílicas no interior de plaquetas, podendo também realizar testes sorológicos e a técnica de PCR - Reação em Cadeia da Polimerase (CRIVELLENTI; BORINCRIVELLENTI, 2015; MEGID et al., 2016; SOUSA et al., 2009).

A babesiose, enfermidade causada pelos protozoários do gênero Babesia, no qual as espécies Babesia canis e Babesia gibsoni são as responsáveis por acometerem cães. As duas espécies parasitam eritrócitos, levando a hemólise intra e extravascular, sendo transmitidas aos animais através durante o repasto sanguíneo do Rhipicephalus sanguineus (MONTEIRO, 2014; URQUHART et al., 1996).

A patogenicidade das manifestações clínicas depende da espécie de Babesia e da intensidade da infecção. Dentre a sintomatologia clínica observada, pode-se ter anemia, mucosas hipocoradas, anorexia, febre, hemoglobinemia, e em casos mais graves, hemoglobinúria e icterícia. No hemograma, é possível observar trombocitopenia, anemia regenerativa, policromasia, anisocitose e alta contagem de reticulócitos. 0 diagnóstico pode ser realizado através de esfregaços sanguíneos com a visualização de Babesia spp. no interior de hemácias, através da sorologia ou utilizando a técnica de PCR (CRIVELLENTI; BORIN-CRIVELLENTI, 2015; GONÇALVES, 2015).

O gênero Ehrlichia abrange bactérias Gram-negativas, as quais são parasitas intracelulares obrigatórios de células hematopoiéticas, como as plaquetas, monócitos e 
granulócitos. A espécie responsável pela erliquiose monocítica canina, é a Ehrlichia canis, transmitida ao hospedeiro através da picada do carrapato Rhipicephalus sanguineus, sendo endêmica em áreas urbanas, onde encontra-se o vetor distribuído em todas as regiões brasileiras. Existem relatos de transmissão também pela transfusão sanguínea, onde o portador na maioria das vezes é infectado cronicamente e mantémse assintomático (CRIVELLENTI; BORIN-CRIVELLENTI, 2015; NAKAGHI et al., 2008; MONTEIRO, 2014).

Dentre as manifestações clínicas, elas são variáveis e muitos cães são portadores assintomáticos, porém as sintomatologias clínicas comumente encontradas são apatia, anorexia, hipertermia, perda de peso, desordens de coagulação, petéquias hemorrágicas, vômitos, edema de membros, mucosas hipocoradas, linfadenomegalia, podendo ter também manifestações oftálmicas, neurológicas, insuficiência hepatorrenal e dispneia (CHIARI, 2010; CRIVELLENTI; BORIN-CRIVELLENTI, 2015).

Em relação às alterações hematológicas, as comumente encontradas são anemia e trombocitopenia, podendo ter também leucopenia. Na fase aguda da doença, é comum encontrar estas alterações devido ao sequestro e consumo através de mecanismos imunológicos. Além dessas, podem ser observadas hiperproteinemia e a hiperglobulinemia, comumente encontradas na fase crônica devido à redução de atividade da medula óssea. Dentre os métodos diagnósticos mais eficazes, destacam-se exames hematológicos aliados a pesquisa em sangue periférico, ao teste sorológico e à técnica de PCR (MEGID et al., 2016; MONTEIRO, 2014; PEIXOTO, 2019; SOUSA et al., 2009).

A hepatozoonose trata-se de uma enfermidade parasitária, possuindo como espécies o Hepatozoon canis e Hepatozoon americanum, sendo este último inexistente no Brasil até o momento. A transmissão para o hospedeiro é causada pela ingestão de carrapatos contendo esporozoítos infectantes de H. canis. Na infecção, podem estar envolvidos os carrapatos Rhipicephalus sanguineus e algumas espécies do Amblyomma, como o A. maculatum, A. aureolatum e ninfas de A. cajennense (CRIVELLENTI; BORINCRIVELLENTI, 2015; MONTEIRO, 2014; URQUHART et al., 1996).

De forma geral, parasitam eritrócitos, mas também é comum serem encontrados em leucócitos. As sintomatologias clínicas comuns de serem observadas incluem apatia, caquexia, mucosas pálidas, diarreia sanguinolenta e febre recorrente, sendo muitas 
vezes uma parasitose assintomática. Dentre os achados laboratoriais, o mais comum é a leucocitose neutrofílica, com desvio à esquerda, podendo ser observado também anemia normocítica normocrômica arregenerativa, decorrente de inflamação crônica. Trombocitopenia só em comum em casos de coinfecção com outros microrganismos patogênicos. O diagnóstico pode ser realizado através da detecção de gametócitos em monócitos e neutrófilos (CONCEIÇÃO, 2017; GONÇALVES, 2015; MEGID et al., 2016; ROTONDANO et al., 2015).

\subsection{Impactos das coinfecções}

A alta ocorrência de doenças infecciosas, principalmente as hemoparasitoses, em cães tem grande importância na rotina clínica veterinária, visto que, as condições clínicas são variáveis, podendo apresentarem desde uma sintomatologia branda até quadros severos, resultando em óbito (PEIXOTO, 2019). Os carrapatos possuem um papel importante na transmissão dessas doenças, sendo grandes vetores e reservatórios de diversos microrganismos (SOUSA et al., 2009). Esses artrópodes estão presentes em altas infestações em cães, sendo o Rhipicephalus sanguineus rotineiramente encontrado na clínica médica veterinária (NAKAGHI et al., 2008).

\subsection{Métodos diagnósticos}

Diversos métodos diagnósticos podem ser utilizados, porém deve-se levar em consideração os métodos mais eficazes para detecção em cada patógeno diferente, visto que, a partir de então, o médico veterinário poderá atuar de forma específica para cada caso (GOLÇALVES, 2015; MEGID et al., 2016; SINK; FELDMAN, 2006).

Dentre as hemoparasitoses, os métodos diagnósticos mais utilizados atualmente podem ser através da detecção de hemoparasitas em esfregaços sanguíneos, porém deve-se levar em consideração a quantidade de células infectadas, variando em diversas situações. Testes sorológicos são bastante sensíveis, mas em geral o custo é elevado, destacando a sorologia por imunofluorescência indireta (RIFI) A técnica molecular PCR, é de extrema importância na fase aguda, sendo de alta sensibilidade, principalmente para os diagnósticos relacionados a fase aguda (KERR, 2003). Além disso, são utilizados também os ensaios imunoenzimáticos, popularmente chamados de ELISA (CRIVELLENTI; BORIN-CRIVELLENTI, 2015; GONÇALVES, 2015; GUEDES et al., 2015; MONTEIRO, 2014). 


\subsection{Atualidades sobre coinfecções}

Atualmente, as coinfecções ocasionadas por hemoparasitas estão cada vez mais presentes na rotina clínica de pequenos animais, principalmente de cães. Diante disso, a demanda por exames rápidos, de alta sensibilidade e especificidade, aliados à um baixo custo, estão sendo cada vez mais preconizados por médicos veterinários. Com a obtenção de diagnósticos precoces em casos em que as sintomatologias clínicas por diversas vezes são inespecíficas, proporciona prognósticos favoráveis aos pacientes coinfectados (CRIVELLENTI; BORIN-CRIVELLENTI, 2015; PEIXOTO, 2019).

Para reduzir casos de infecções ocasionadas por hemoparasitas e, consequentemente, de coinfecções também, é de extrema importância controlar os vetores, visando sua eliminação, visto que os mesmos possuem grande importância na transmissão de patógenos (BREDA et al., 2018; MONTEIRO, 2014).

\subsection{ASPECTOS RELACIONADOS À SAÚDE PÚBLICA}

As zoonoses transmitidas por carrapatos possuem impacto significativo à saúde pública, causando danos diretos ao bem-estar dos seres humanos. As interações entre as cadeias ecológicas favorecem a extensão cíclica da cadeia de infecção, sendo que os artrópodes podem utilizar como hospedeiro alternativo, o homem. Dentre as principais zoonoses transmitidas através de vetores, como é o caso dos carrapatos, podemos destacar a febre maculosa, borreliose, babesiose, erliquiose e tularemia (ARAÚJO et al., 2015; ÁVILA-PIRES, 1989; SILVA, 2009).

Em geral, as zoonoses transmitidas por carrapatos possuem alta letalidade, por conta da falta de especificidade me tratamentos, além de serem consideradas doenças reemergentes. Diante desses agravos, a expansão da população para zonas rurais e a prática de momentos de lazer na natureza, facilitam a ocorrência da proximidade dos vetores com os seres humanos, resultando na ocorrência de algumas zoonoses (ARAÚJO et al., 2015; SILVA, 2009).

A febre maculosa é ocasionada pela Rickettsia rickettsii, bactéria Gram-negativa, intracelular obrigatória, a qual está presente nos carrapatos, considerados focos endêmicos. Esses vetores são capazes de transmitirem a R. rickettsii e também servem como reservatórios, sendo capazes de transmitirem a bactéria via transovariana à sua progênie. No Brasil, os carrapatos Amblyomma cajennense e A. aureolatum, são os 
principais vetores desta enfermidade. Porém, são diversas as espécies capazes de serem reservatório da R. rickettsii, como por exemplo, o Rhipicephalus sanguineus (ARAÚJO et al., 2015; MONTEIRO, 2014).

Os vetores tornam-se infectados, ao fazerem o repasto sanguíneo em um animal que esteja infectado, sendo possível fazer sua transmissão posteriormente aos animais susceptíveis, incluindo o homem como hospedeiro acidental (FONSECA; MARTINS, 2007; PINTER et al., 2011). A febre maculosa é considerada uma doença grave, multissistêmica, com o período de incubação médio de sete dias, onde os principais sintomas clínicos, destacam-se febre, mialgia, mal-estar, vômitos, náuseas e o principal, exantema. A taxa de mortalidade está diretamente relacionada ao diagnóstico precoce e tratamento eficaz (ARAÚJO et al., 2015; DEL FIOL et al., 2010).

A borreliose, também conhecida como doença de Lyme, é ocasionada pela Borrelia burgdorferi, bactéria Gram-negativa, a qual é transmitida pelos carrapatos, seus principais vetores (GALVÃO et al., 2005; SOARES et al., 2000). Sua transmissão ocorre através da picada do carrapato, principalmente o Amblyomma cajennense, porém para que a bactéria seja transmitida, ele precisa ficar fazendo seu repasto sanguíneo por no mínimo vinte e quatro horas no seu hospedeiro acidental, o homem (ARAÚJO et al., 2015; MONTEIRO, 2014; SILVA, 2009).

Trata-se de uma doença multissistêmica, com período de incubação médio de trinta e dois dias, cuja principal sintomatologia clínica, incluem eritema ao redor da picada do artrópode, podendo desenvolver eritema migratório e se espalhar para outras regiões corpóreas, febre, cefaleia, mialgia, artalgia e mal-estar. Em casos mais graves, onde não foi realizado o diagnóstico precoce e o tratamento, podem ocorrer o comprometimento do sistema nervoso e alterações oftálmicas (BARBOSA et al., 2011; MASSARD; FONSECA, 2011; SOARES et al., 2000).

A babesiose, doença causada pelo protozoário Babesia microti, possui poucos registros no Brasil, sendo assim, sua patogenicidade é pouco elucidada. É transmitida aos humanos através dos carrapatos do gênero Ixodes, o período de incubação varia de sete à vinte e oito dias. Em relação aos sinais clínicos, os principais são febres intercaladas, gastroenterite, cansaço fácil, anemia, mal-estar generalizado, calafrios e cefaleia. Em casos mais graves, se não diagnosticada e não tratada, o ser humano infectado pode chegar ao óbito (BARBOSA et al., 2011; MONTEIRO, 2014; SILVA, 2009). 
A erliquiose possui como agente etiológico a bactéria Ehrlichia canis, transmitida ao homem através do carrapato Rhipicephalus sanguineus, o qual é reservatório natural desta bactéria, podendo ser pela picada do mesmo ou em contato com o sangue infectado do vetor e uma área de pele lesionada no homem. Refere-se a uma doença multissistêmica, atingindo principalmente o fígado e o sistema gastrointestinal (MASSARD; FONSECA, 2011; MONTEIRO, 2014). Dentre os principais sintomas clínicos, é possível observar vômito, náusea, dor na região abdominal, icterícia, hepatoesplenomegalia e diarreias recorrentes. Em humanos ela pode se manifestar sob duas diferentes formas, erliquiose monocítica e granulocítica, onde a primeira apresenta-se de forma mais branda, levando à queda na imunidade e a segunda de forma moderada à grave. O período de incubação possui em média dez dias e, se não diagnosticada e tratada precocemente, pode levar à falência de órgãos multissistêmica (BARBOSA et al., 2011; MASSARD; FONSECA, 2011; SILVA, 2009).

A tularemia possui como agente etiológico, a bactéria Gram-negativa Francisella tularensis, parasita intracelular de macrófagos, transmitida ao homem através de vetores, principalmente os carrapatos e também, através de contato com carcaças de animais infectados. Dentre as principais sintomatologias clínicas, destacam-se a febre alta, cefaleia, dor no corpo generalizada, úlcera, linfonodos reativos, tosse, artralgia, vômito, conjuntivite e gastroenterite (MASSARD; FONSECA, 2011; SILVA, 2009). O período de incubação pode variar, sendo de três a cinco dias e, em alguns casos, pode chegar até vinte e um dias. Quando diagnosticada e tratada precocemente, o prognóstico costuma ser favorável (GALVÃO et al., 2005; NAKAZAWA et al., 2007).

Por diversas vezes essas zoonoses são subdiagnosticadas e, com isso, a ocorrência das mesmas resultam em uma alta taxa de letalidade, e dependendo dos casos, até mesmo de mortalidade. Com isso, evidencia-se a necessidade de elucidar de uma melhor forma a patogenia dessas doenças infecciosas, as formas de transmissão e os vetores, para que haja uma linha de raciocínio clínico focada em diagnósticos e formas de tratamento eficazes, ambos ocorrendo de forma precoce, proporcionando prognósticos favoráveis (ARAÚJO et al., 2015; MASSARD; FONSECA, 2011; SILVA, 2009). 


\section{REFERÊNCIAS}

ARAÚJO, R. P.; NAVARRO, M. B. M. A.; CARDOSO, T. A. O. Febre maculosa no Brasil: estudo da mortalidade para a vigilância epidemiológica. Cadeia de Saúde Coletiva, Rio de Janeiro/RJ, v. 23, n. 4, p. 354-361, 2015.

ÁVILA-PIRES, Fernando Dias de. Zoonoses: hospedeiros e reservatórios. Cadeia de Saúde Pública, Rio de Janeiro/RJ, v. 5, n. 1, jan./mar., 1989.

BARBOSA, A. D.; MARTINS, N. R. S.; MAGALHÃES, D. F. Zoonoses e saúde pública: riscos da proximidade humana com a fauna silvestre. Ciência Veterinária nos Trópicos, Recife/PE, v. 14, n. 3, p. 1-9, jan./dez., 2011.

BOOZER, A. L.; MACINTIRE, D. K. Canine babesiosis. The Veterinary Clinics of North America: Small Animal Practice, Philadelphia/PA, v. 33, n. 4, p. 885-904, 2003.

BORIN, S.; CRIVELENTI, L. Z.; FERREIRA, F. A. Aspectos epidemiológicos, clínicos e hematológicos de 251 cães portadores de mórula de Ehrlichia spp. naturalmente infectados - Universidade Federal de Minas Gerais - Escola de Veterinária. Arquivo Brasileiro de Medicina Veterinária e Zootecnia, Belo Horizonte/MG, v. 61, n. 3, p. 566-571, 2009.

BREDA, J. C. et al. Hemoparasitoses em cães: análise de dados laboratoriais. Revista Acadêmica Ciência Animal, Caxias do Sul/RS, v. 16, ago. 2018.

BIRCHARD, S. J.; SHERDING, R. G. Manual Saunders: Clínica de Pequenos Animais. São Paulo: Roca, 1998.

BULLA, C. et al. The relationship between the degree of thrombocytopenia and infection with Ehrlichia canis in an endemic area. Veterinary Research, Botucatu/SP, v. 35, n. 1, p. 141-146, mar., 2004.

CHEVILLE, Norman F. Introdução à parasitologia veterinária. Formatado: Inglês (Estados Unidos). Barueri/SP: Manole, 2009. 3a ed., cap. 13.

CHIARI, Maria Fernanda. Novo método de diagnóstico para Ehrlichia canis: PCR $x$ Lâmpada. Dissertação (Mestrado em Multidisciplinar) - Universidade Federal de São Carlos. São Carlos/SP, 2010.

COELHO, W. M. D et al. Detecção de coinfecções por Leishmania (L.) chagasi, Trypanosoma evansi, Toxoplasma gondii e Neospora caninum em cães. Ars Veterinaria, Jaboticabal/SP, v. 29, n. 3, p. 169-174, 2013.

CONCEIÇÃO, Luciana Auxiliadora Viebranzt da. Coinfecção por Hepatozoon canis, Ehrlichia canis e Babesia canis vogeli no Brasil. Monografia (Especialista em Patologia Clínica Veterinária) - Universidade Federal de Mato Grosso, Cuiabá/MT, 2017. 
CRIVELLENTI, L. Z.; BORIN-CRIVELLENTI, S. Casos de Rotina em Medicina Veterinária de Pequenos Animais. 2a ed. São Paulo: MedVet Ltda., 2015.

DANIEL, Alexandre G. T. Casos em medicina felina. São Paulo: MedVet Ltda., 2015.

DEL FIOL, F. S. et al. A febre maculosa no Brasil. Revista Pan-americana de Saúde Pública, São Paulo/SP, v. 27, n. 6, p. 461-466, 2010.

FÁRACO, Ceres Berger Interação humano-animal. Ciência Veterinária nos Trópicos, Recife/PE, v. 11, suplemento 1, p. 31-35, abril, 2008.

FIGUEIREDO, Mônica Ramos. Babesiose e erliquiose caninas. Monografia (Especialização em Clínica Médica de Pequenos Animais - Qualittas). Rio de Janeiro/RJ, 2011.

FONSECA, L.; MARTINS, A. Febre maculosa: revisão de literatura - artigo de revisão. Saúde e Ambiente em Revista, Rio de Janeiro/RJ, v. 2, n. 1, p. 1-20, 2007.

GALVÃO, M. A. M. et al. Riquetsioses no Brasil e Portugal: ocorrência, distribuição e diagnóstico. Revista de Saúde Pública, São Paulo/SP, v. 39, n. 5, out., 2005.

GONÇALVES, Vinícius Mendes. Alterações hematológicas em cães com suspeita clínica de hemoparasitoses atendidos na rotina clínica do Hospital Veterinário do CCA, UFPB. Monografia (Bacharel em Medicina Veterinária) - Universidade Federal da Paraíba, Areia/PB, 2015.

GUEDES, P. E. B. et al. Canine Ehrlichiosis: prevalence and epidemiology in northeast Brasil. Brazilian Journal of Veterinary Parasitology. Jaboticabal/SP, v. 24, n. 2, p. 115-121, 2015.

HARRUS, S.; WANER, T. Diagnosis of canine monocytotropic ehrlichiosis (Ehrlichia canis): an overview. The Veterinary Journal, v. 187, n. 3, p. 292-296, mar., 2011.

KERR, Morag G. Exames laboratoriais em medicina veterinária; bioquímica clínica e hematologia. Formatado: Inglês (Estados Unidos). 2a ed. São Paulo: Roca, 2003.

MASSARD, C. L.; FONSECA, A. H. Carrapatos e doenças transmitidas comuns ao homem e aos animais. Ciência Veterinária nos Trópicos, Recife/PE, v. 14, n. 3, p. 1-9, jan./dez., 2011.

MEGID, J.; RIBEIRO, M. G.; PAES, A. C. Doenças infecciosas em animais de produção e de companhia. 1a ed. Rio de Janeiro: Roca, 2016.

MENDONÇA, C. S. et al. Erliquiose canina: Alterações hematológicas em cães domésticos naturalmente infectados. Bioscience Journal, Uberlândia/MG, v. 21, n. 1, p. 167174, 2005. 
MONTEIRO, Silvia Gonzalez. Parasitologia na medicina veterinária. São Paulo: Roca, 2014. 1a ed., cap. 3.

MOREIRA, S. M. et al. Retrospective study (1998-2001) on canine ehrlichiosis in Belo Horizonte, MG, Brazil. Arquivo Brasileiro de Medicina Veterinária e Zootecnia, Belho Horizonte/MG, v. 55, n. 2, p. 141-147, abr., 2003.

NAKAGHI, Andréa Cristina Higa. Canine ehrlichiosis: clinical hematological, serological and molecular aspects. Ciência Rural, Santa Maria/RS, v. 38, n. 3, mai./jun., 2008.

NAKAZAWA, Y. et al. Climate change effects on plague and tularemia in the United States. Vector-Borne and Zoonotic Diseases, v. 7, n. 4, p. 529-540, 2007.

OLIVEIRA, A. B.; LOURENÇÃO, C.; BELIZARIO, G. D. Índice Estatístico de Animais Domésticos Resgatados da Rua vs Adoção. Revista Dimensão Acadêmica, Castelo/ES, v. 1, n. 2, p. 5-7, jul./dez. 2016.

OLIVEIRA, Mariângela Silva. Estudo retrospectivo da anaplasmose em cães no Hospital Veterinário da Universidade Federal Rural do Semi-Árido. Monografia (Bacharel em Medicina Veterinária) - Universidade Federal Rural do Semi-Árido, Mossoró/RN, 2019.

PEIXOTO, Cristiane Seide. Alterações oculares e hematológicas em cães acometidos por Ehrlichia Canis e co-infecções. Mestrado (Ciências Animal) - Universidade de Brasília - Faculdade de Agronomia e Medicina Veterinária. Brasília/DF, 2019.

PINTER, A. et al. Febre maculosa brasileira. Boletim Epidemiológico Paulista, São Paulo/SP, v. 8, n. 1, p. 3-31, 2011.

ROTONDANO, Tereza Emmanuelle de Farias. Survey of Ehrlichia canis, Babesia spp., Hepatozoon spp. in dogs from a semiarid region of Brazil. Revista Brasileira de Parasitologia Veterinária, Jaboticabal/SP, v. 24, n. 1, jan./mar., 2015.

SALGADO, Fabiana Pessoa. Identificação de hemoparasitos e carrapatos de cães procedentes do Centro de Controle de Zoonoses de Campo Grande estado do Mato Grosso do Sul, Brasil. Mestrado (Ciência Animal - Saúde Animal) Universidade Federal de Mato Grosso do Sul. Campo Grande/MS, 2006.

SILVA, Ana Claudia Silveira da. Zoonoses transmitidas por carrapatos: aspectos regionais e vigilância no Vale do Paraíba, estado de São Paulo. Mestrado (Vigilância em Saúde Pública) - Universidade de São Paulo - Faculdade de Saúde Pública. São Paulo/SP, 2009.

SINK, C. A.; FELDMAN, B. F. Urinálise e hematologia: laboratorial para o clínico de pequenos animais. Formatado: Inglês (Estados Unidos). São Paulo/SP: Roca, 2006. 1 a ed., cap. 5. 
SOARES, C. O. et al. Borrelioses, agentes e vetores. Pesquisa Veterinária Brasileira, Rio de Janeiro/RJ, v. 20, n. 1, p. 1-19, jan./mar., 2000.

SOUSA, V. R. F. et al. Coinfecção por Anaplasma platys e Ehrlichia canis em cães diagnosticada pela PCR. Acta Scientiae Veterinariae. v. 37, n. 3, pag. 281-283, jan., 2009.

TORRES, F. D.; FIGUEIREDO, L. A.; FAUSTINO, M. A. G. Ectoparasitos de cães provenientes de alguns municípios da região metropolitana do Recife, Pernambuco, Brasil. Revista Brasileira de Parasitologia Veterinária, Recife/PE, v. 13, n. 4, p. 151-154, 2004.

URQUHART, G. M. et al. Parasitologia veterinária. Formatado: Inglês (Estados Unidos). 2a ed. Rio de Janeiro: Guanabara Koogan S. A., 1998. 


\section{CAPÍTULO VIII}

\section{DERMATÓFILOS ISOLADOS DA PELE DE CÃES}

DDI: 10.51859/amplla.pdi443.1121-8

Mollyne Martins Chitolina ${ }^{1}$

Debora da Silva Freitas Ribeiro ${ }^{2}$

Juliana Evangelista Bezerril ${ }^{2}$

Eric Mateus Nascimento de Paula ${ }^{2}$

\footnotetext{
'Médica Veterinária Autônoma. Egressa do Curso de Medicina Veterinária do Centro Universitário de Mineiros UNIFIMES

${ }^{2}$ Docente do Curso de Medicina Veterinária do Centro Universitário de Mineiros - UNIFIMES.
}

\section{RESUMO}

A dermatologia veterinária é uma área de especialização médica com grande crescimento entre os profissionais. Esse aumento expressivo tem se dado por diversos fatores, mas principalmente pela rápida disseminação de alguns agentes infeciosos. Especialmente, destaca-se o grupo dos fungos. Diante disso, o objetivo desse trabalho é abordar os principais aspectos clínicos e epidemiológicos da Dermatofitose Canina, por meio de uma revisão de literatura. A dermatofitose é uma doença bastante comum em climas quentes e úmidos, e sua incidência, varia de acordo com o clima e as estações do ano, sendo caracterizada pelo desenvolvimento de lesões cutâneas multifocais ou localização apenas na região contaminada, tendo como complicação a generalização crônica das lesões. Portanto, os cuidados para a prevenção e um diagnóstico preciso para dar início ao tratamento adequado são indispensáveis para evitar a disseminação desta doença.

Palavras-chave: Microsporum gypseum. Microsporum canis. Revisão. Trichophyton mentagrophytes.

\section{INTRODUÇÃO}

O Brasil possui o terceiro maior mercado pet do mundo, com uma população de animais domésticos que cresce gradativamente, sendo que nos últimos anos ultrapassou 130 milhões. Seguindo este panorama, há também um crescimento com os cuidados com esses animais de estimação, o que faz com que os tutores busquem profissionais médicos veterinários mais capacitados, com o intuito de promover saúde para seus animais (MOURA, 2016). 
A dermatologia é uma das especialidades da medicina veterinária que se expande cada vez mais, devido ao aumento da preocupação e cuidado com os animais de estimação, visto que esses são considerados um membro da família, preconizando a saúde dos mesmos (FERNANDES et al., 2013).

Mesmo com o avanço da Medicina Veterinária, algumas doenças infecciosas e parasitárias ainda têm elevada prevalência, particularmente em animais domésticos, como os gatos e os cães (NEVES, 2011).

As dermatofitoses são micoses cutâneas superficiais causadas pelos fungos dependentes de queratina presente nos pelos, pele e unhas, denominados de dermatófitos, dentre os fungos encontrados, englobam-se os Microsporum gypseum; Microsporum canis; Trichopyton mentagruphytes (NEVES, 2011), que são objetos de estudo do referido trabalho. A doença é transmitida por meio do contato direto com pelos dos animais infectados, geralmente acomete cães e gatos (MENDOZA et al., 2009).

As dermatofitoses são consideradas um problema de saúde pública, sendo foco de vários estudos por serem uma das principais enfermidades dermatológicas na rotina clínica, principalmente pelo contato dos animais domésticos com os seres humanos, o que pode provocar a contaminação de ambos (FERNANDES et al., 2013).

É de suma importância que o clínico veterinário realize todos os procedimentos possíveis durante o diagnóstico de seu paciente. Dentre as técnicas complementares, destaca-se o raspado de pele, que auxilia bastante na identificação do agente etiológico. Durante o tratamento é preciso tomar muito cuidado ao entrar em contato com o animal, uma vez que a doença é transmitida aos humanos também (SILVA et al., 2011).

O presente trabalho é de grande interesse aos estudantes de medicina veterinária e aos médicos veterinários por enfatizar, abordagens necessárias na prática clínica. Nota-se que é de extrema valia que sejam realizados estudos referentes aos aspectos epidemiológicos, micológicos, patogenia, sinais clínicos, diagnóstico e profilaxia das dermatofitoses, visto que a enfermidade canina tem uma grande casuística na rotina profissional. 


\section{REVISÃO BIBLIOGRÁFICA}

\subsection{Definição}

As micoses são classificadas em superficiais, subcutâneas e sistêmicas, com base no grau de comprometimento do tecido e local de instauração do agente infeccioso. Diante das micoses existentes, as superficiais possuem maior evidência, devido a frequência em que é relatada em humanos e animais, sendo uma das mais incidentes as dermatofitoses (CANAVARI et al., 2017).

A dermatofitose, comumente conhecida como tinea, é uma doença cutânea contagiosa causada por fungos dermatófitos, que se apropriam da queratina para se nutrirem e multiplicar. Existem inúmeros estudos sobre essa enfermidade, devido sua rápida disseminação e seu caráter zoonótico (FIGUEIREDO et al., 2015).

Os fungos são microrganismos que se fazem presentes no meio ambiente, como no ar, na água, no solo e na microbiota de animais e humanos. Fazem parte do Reino Fungi, são eucariontes e heterótrofos, podem ser unicelulares ou pluricelulares, sendo visualizados microscópica ou macroscopicamente (SILVA; COELHO, 2006).

Estudos indicam a existência de mais de $\mathbf{2 5 0}$ mil espécies de fungos, sendo que em média trezentas participam de processos patológicos em animais e seres humanos. Dentre as várias espécies de fungos, os dermatófitos são os causadores das dermatofitoses, visto que essa é uma das micoses que apresenta maior índice de infecção (LANA, 2016).

\subsection{Etiologia}

Os dermatófitos são do reino Fungi e filo Mycota, são fungos pertencentes a família Arthrodermataceae. Sendo os principais, Epidermophyton floccosum, Microsporum canis, Microsporum gypseum e Trichophyton rubrum (LANA et al., 2016). Dentre as três espécies mais comumente encontradas como as citadas acima, estes são diferenciados de acordo com o modo dos macroconídeos estruturas de reprodução sexuada grandes e dos microconídios estruturas de reprodução sexuada menores. Representados na (figura 1) (CAVALCANTE, 2006). 
Figura 1 - Diagrama de caracterização micromorfológica dos principais gêneros de dermatófitos

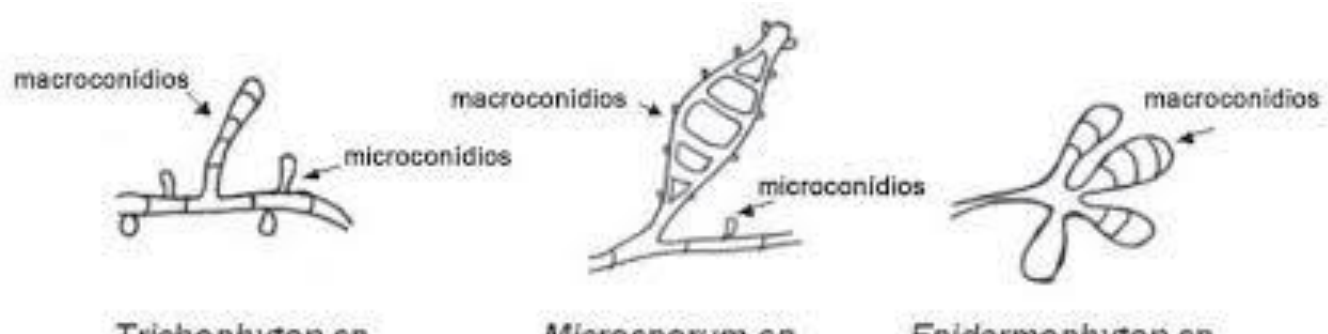

Trichophyton sp

Microsporum sp

Epidermophyton sp

Fonte: (FRAGA, 2017).

Esses fungos são filamentos, apresentam macroconídeos simétricos, com três a sete septos de paredes finas, em média possuem seis células, com superfície levemente rugosa e extremidade proximal truncada e a distal arredondada (MENDOZA et al., 2009). Microbiologicamente, as espécies dos fungos dermatófitos, são principalmente queratinofílicos, além de serem hialinos, septados, filamentosos, podendo ser também artroconidiados, capazes de parasitar tecido queratinizado (BAPTISTA, 2015).

Outra característica desses microrganismos é a capacidade ubíqua, que os torna impossível de serem erradicados. Além disso, esses se reproduzem de forma assexuada e possuem a estrutura celular caracterizada por filamentos designados hifas (LOPES; DANTAS, 2016).

Em cultura, os fungos possibilitam a identificação das hifas septadas que formam o micélio e os conídios. Essa estrutura relacionada a reprodução assexuada pode diferir quanto a formação e morfologia (forma, disposição, número, tamanho) entre as espécies, o que auxilia na identificação delas. Os conídios mais encontrados entre eles são: os microconídios unicelulares e os macroconídios pluricelulares (LANA et al., 2016).

Esses dermatófitos podem ser classificados também quanto seu habitat primário (animais, solo ou humanos) em: zoofílicos capazes de provocar uma inflamação aguda; e geofílicos e antropofílicos podendo provocar uma infecção crônica e lenta (MEDEIROS; CREPALDI; TOGNOLI, 2009).

Os fungos reconhecidos como zoofílicos são primeiramente isolados em animais, porém, através do contato direto com os animais contaminados os humanos também, podem ser alvo destes. Já os fungos geofílicos tem como receptor o solo e ocasionalmente contamina animais e humanos. E os antropofílicos restritos apenas aos seres humanos e raramente infectam os animais (OLIVEIRA et al., 2013). 
MADRID et al. (2012) descreve mais de 20 espécies de fungos queratinófilos capazes de desenvolver dermatofitoses em cães. Diante disso, faz se necessário a identificação da espécie envolvida no desenvolvimento infeccioso, já que cada tipo de dermatófito manifesta uma particularidade epidemiológica especifica.

Um dos principais fungos causadores da dermatofitose, acomete os cães é o Microsporum Gypseum, apresenta colônia filamentosa e pulverulenta, com hifas septadas hialinas, macronideos em fuso, com paredes finas e controle da célula interior. Representado na (figura 2) (LANA, 2016).

Figura 2 - Esta é uma fotomicrografia do fungo Microsporum gypseum usando a técnica de coloração azul do lactofenol. Dermatophyte M. gypseum, um habitante natural do solo, pode causar tinea corporis, tinea capitis em humanos e animais, 1969

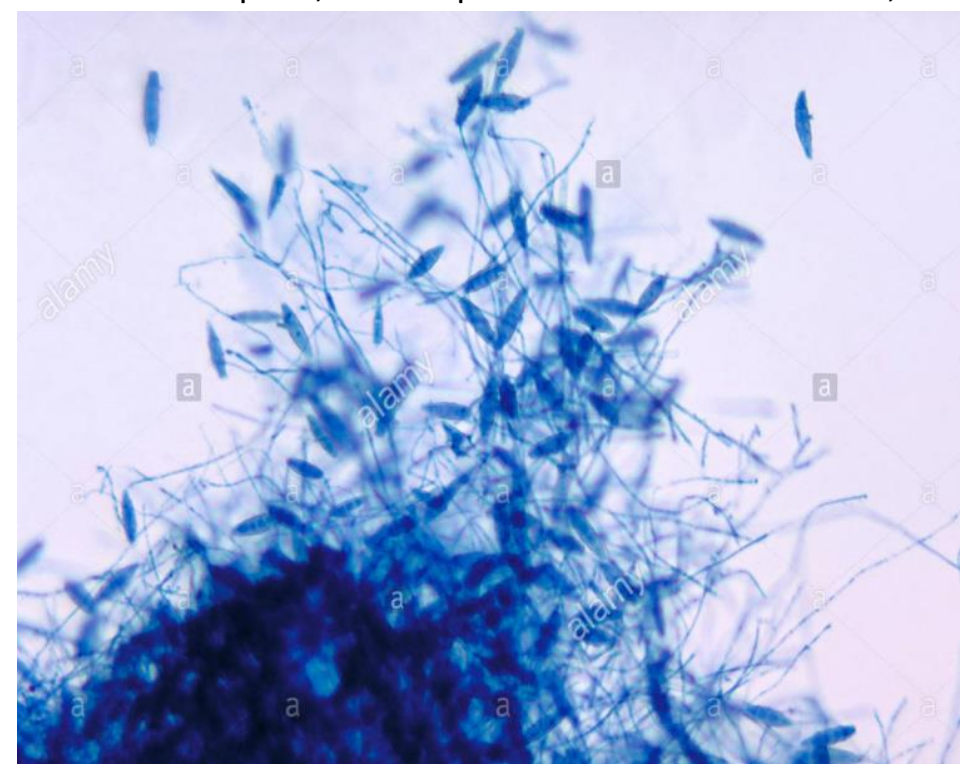

Fonte: (GADO, 2019).

Outra espécie bastante conhecida é o Microsporum canis, que possuem macroconídios no formato de fuso, com paredes rugosas, grossas, hifas na superfície, apresenta numerosas septações podendo variar entre cinco e sete, porém em algumas ocasiões são visualizadas mais destas. Além disso, possuem colônia filamentosa, plana, inverso de coloração branca e reverso amarelo-ouro alaranjado. Representado na (figura 3) (PRADO, 2007). 
Figura 3 - Fotomicrografia do fungo Microsporum canis utilizando a técnica de coloração com lactofenol de algodão azul. M. canis, um dermatófito zoofílico é freqüentemente encontrado em cães e gatos, é uma causa comum de tinea corporis, tinea capitis em humanos, 1969

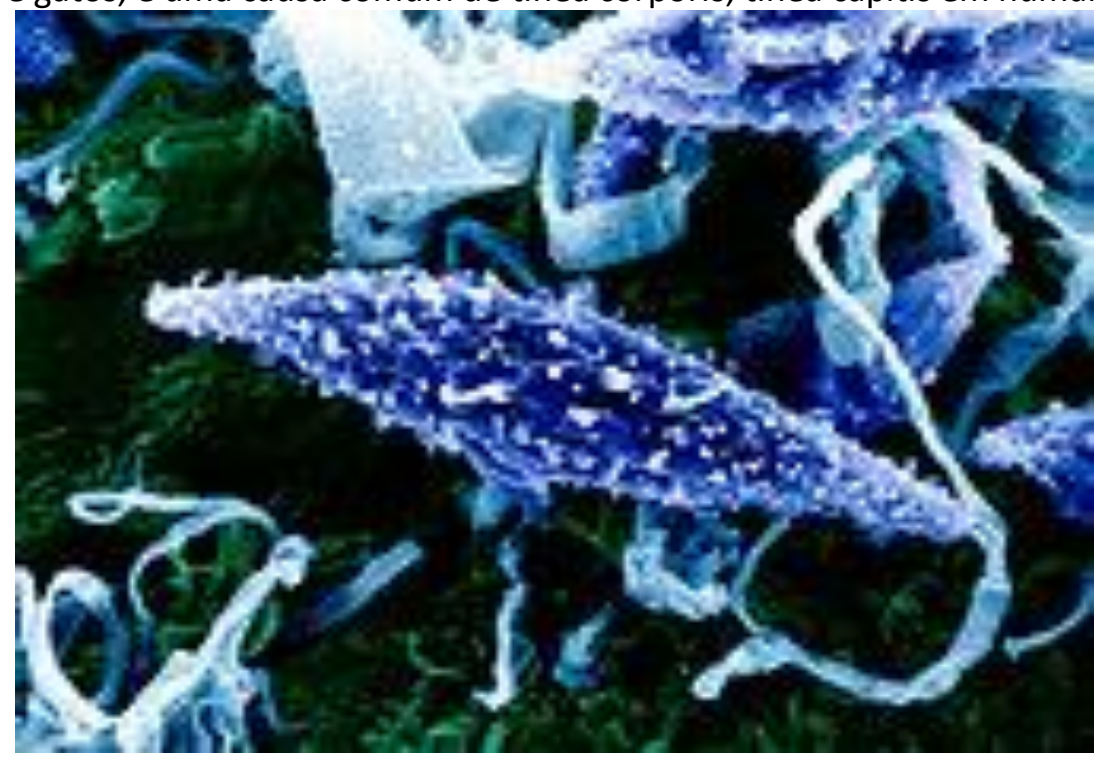

Fonte: (GADO, 2019).

O fungo da espécie Trichopyton mentagrophytes dispõe de duas variações: de característica antropofílica, um dos causadores de dermatofitose em humanos, possui colônias algodonosas ou veludosas, de coloração branco amarelo conhecidos como T. mentagrophytes variação interdigitale. E os zoofílicos T. mentagrophytes variação mentagrophytes de textura pulverulenta, com a coloração branco amarelo. Representado na (figura 4) (OLIVEIRA et al., 2015). 
Figura 4 - Cultura contendo o fungo Trichopyton mentagruphytes, 1964. De frente, a cor é branca a amarelo-bege brilhante ou vermelho-violeta. $O$ gênero Trichophyton habita o solo, os seres humanos ou animais e é uma das principais causas de infecções de cabelos, pele e unhas, nomeadamente dermatofitoses, em humanos a cor é branca a amarelo-bege brilhante ou vermelho-violeta

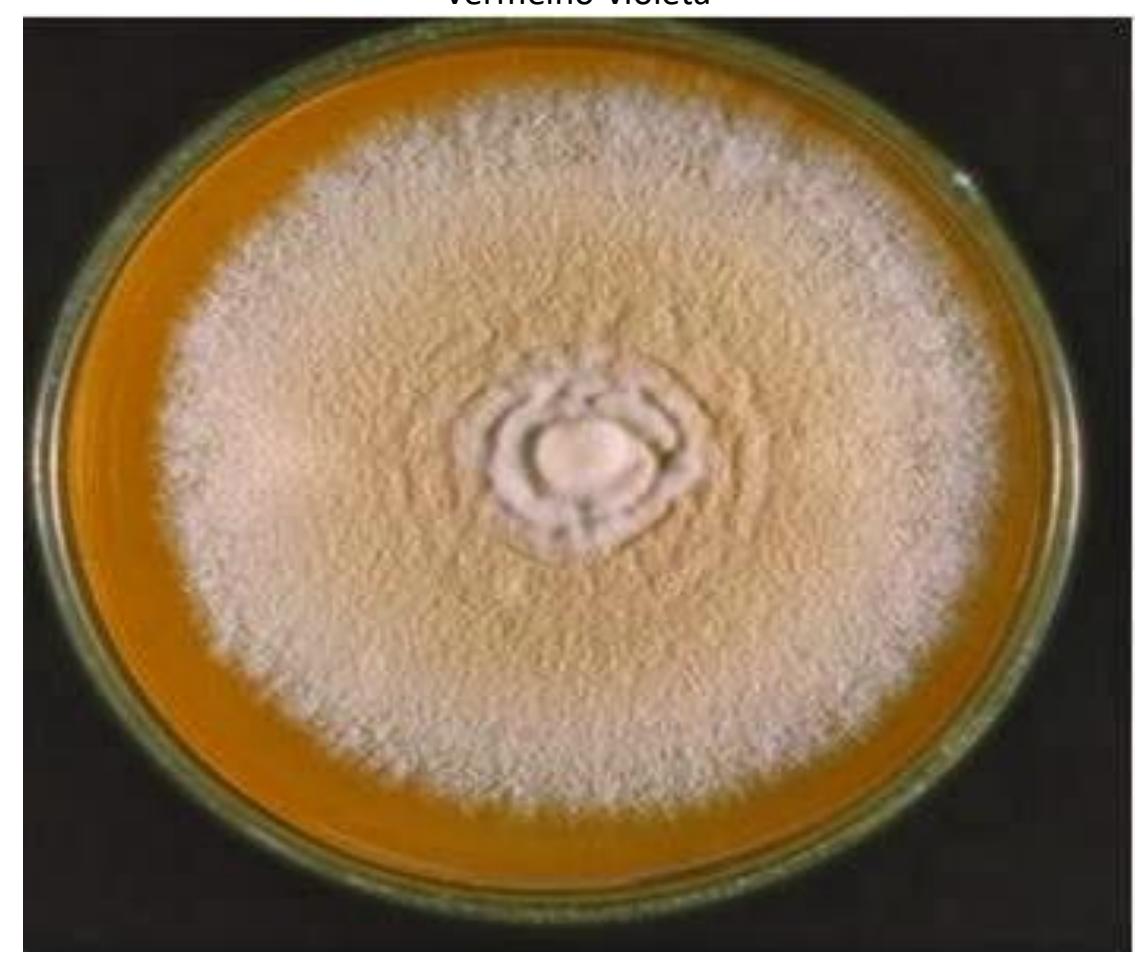

Fonte: (GADO, 2019).

\subsection{Epidemiologia}

As dermatofitoses têm sido bastante estudadas e descritas em todo o mundo.

Devido a frequência com que os dermatófitos se multiplicam, esse processo irá variar de acordo com a distribuição geográfica, fatores ambientais, idade, sexo e raça, bem como com a existência de variações durante as diferentes estações climáticas (SILVA et al., 2011).

Estudos apontam predisposições quanto a algumas casuísticas, em relação a faixa etária, em que os cães mais jovens estão mais susceptíveis devido a imaturidade do sistema imunológico. Já relacionado o sexo pode-se notar que os machos são mais acometidos, entretanto, não existe estudos vinculado a predisposição sexual (CECONI et al., 2018).

Esses fungos possuem perfis epidemiológicos diversificados quanto aos aspectos sazonais, regionais, condições higiênico-sanitárias, exposição e frequência de contato com animais infectados (LANA et al., 2016). 
Dermatófitos estão presentes habitualmente no solo, em seres humanos e animais. A infecção pode ser ocasionada pelo contato direto entre animais, entre humanos ou entre humanos e animal. Além disso, essa doença atinge principalmente, cães que apresentam sua função imunológica debilitada, que sejam muito novos ou velhos e que estejam deprimidos por ficarem mais vulneráveis a infecções crônicas ou generalizadas, inclusive as dermatofitoses (MEDEIROS; CREPALDI; TOGNOLI, 2009; PRADO, 2007).

A raça pode ser outro fator predisponente, sendo os cães da raça Yorkshires, os mais acometidos pelo Microsporum canis (CECONI et al., 2018). As dermatofitoses ocorrem mundialmente, com maior a frequência em país tropicais e subtropicais. No Brasil, a prevalência dessa patologia varia de 18 a 20\% um elevado percentual diante das demais micoses (REZENDE et al., 2008).

Na região Sudeste do Brasil, o $M$. canis foi o fungo mais isolado em dermatofitoses de pequenos animais, seguido de Trichophyton mentagrophytes e M. gypseum. Na região Nordeste os dermatófitos acometeram 13,16\% dos cães e $27,27 \%$ dos gatos avaliados na pesquisa, sendo o gênero Microsporum o mais isolado, estes dados não diferem do diagnóstico humano, onde apontam o M. canis como o zoofílico mais isolado em Tinea capitis na cidade de São Paulo e Fortaleza, respectivamente (ANDRADE; ROSSI, 2019).

\subsection{Patogenia}

A infecção provocada por esses fungos se dá por meio da penetração do dermatófitos nos folículos pilosos, a partir de então, se inicia o processo de estabelecimento da infecção, quando estes alcançam a cutícula do pelo, através de enzimas queratolíticas. Além disso, alguns fungos produzem enzimas que irão facilitar a invasão na queratina da epiderme e na pelagem do animal por meio da hidrolise da queratina, como: protease, fosfatases, nucleases, lípases e glicosidases (LOPES; DANTAS, 2016).

As queratinas são proteínas estruturais "que formam filamentos que fazem parte do citoesqueleto do queratinócito", agindo como uma barreira epidérmica, protegendo a pele contra substâncias químicas, ressecamento, traumatismo físico e microrganismos (BOHJANEN, 2013, p. 01). 
Para que essa contaminação desenvolva as lesões são necessárias condições favoráveis para o crescimento e proliferação destes, como clima quente e úmido e ph alcalino. Caso essas características não estiverem presentes, os esporos fúngicos são mecanicamente extraídos, pois não podem combater a flora normal da pele, em alguns casos esses dermatófitos resistem no pelo do animal até que haja condições ótimas para a infecção (LANA, 2016).

Segundo Cavalcante (p.05, 2006)

A exposição ao agente não garante a infecção devido a: remoção mecânica dos conídios, falta de sucesso na competição com a microbiota normal do animal, propriedades fungicidas dos ácidos graxos produzidos pelas glândulas sebáceas e resistência imunológica do hospedeiro.

A infecção ocorre no tecido queratinizado, por meio da penetração nos pelos, pele e unhas, ocasionando danos à saúde do animal, provocando a descamação da superfície epitelial, além da queda do pelo, reação inflamatória e hipersensibilidade, desenvolvendo as lesões propriamente ditas. Porém, a manifestação clínica dessa patologia é bastante variada (CANAVARI et al.,2017).

Além disso, na região da alopecia a contaminação ocorre por contato direto ou por meio de pelos e escamas espalhados pelo ambiente e através de fômites contaminados (CECONI et al., 2018).

Os fungos crescem do centro da lesão para as bordas, tornando essas circulares, com alopecia circinada, centro descamativo, irregular ou difusa e de expansão centrífuga, com bordos eritematosos e vesiculares (CAVALCANTE, 2006).

\subsection{Sinais Clínicos}

Frequentemente, as lesões, se apresentam em formato circular e tem bordas espessas que formam crostas, deixando os pelos mais fracos e quebradiços. 0 diagnóstico correto é indispensável quando se trata de doença de pele. As afecções cutâneas são bastante semelhantes (SOUZA, 2012).

Alguns animais acometidos por dermatofitose são assintomáticos, dificultando o reconhecimento da patologia, consequentemente interferindo negativamente nas fases de diagnóstico, tratamento e de prevenção, atrapalhando nos cuidados com animal e ambiente contaminado (MATTIE, 2009). 
Os sinais clínicos dessa patologia, podem variar. As lesões atingem principalmente a face, os membros, a cauda e as orelhas, tendo como complicação a generalização crônica das lesões, em que irá afetar todo o corpo do animal, ou até mesmo poderá haver uma cura natural (SILVA, 2013).

O período de incubação pode variar de quatro dias a 4 semana, sendo que os sinais clínicos característicos dessa patologia, são decorrentes de uma resposta inflamatória (CANAVARI et al., 2017).

Durante o processo inflamatório os fungos destroem os pelos e modificam sua composição de queratina, resultando em alopecia com um anel vermelho de inflamação, rubor, descamação e prurido, geralmente os cães desenvolvem a lesão em forma de anel com o cento curado, pápulas foliculares, crosta nas bordas, conforme a (figura 5 e 6) (MATTEI; BEBER; MADRID, 2014).

Figura 5 - Cão da raça Dachshund, com múltiplas lesões alopecias no dorso e membros anteriores, provocadas pela dermatofitose

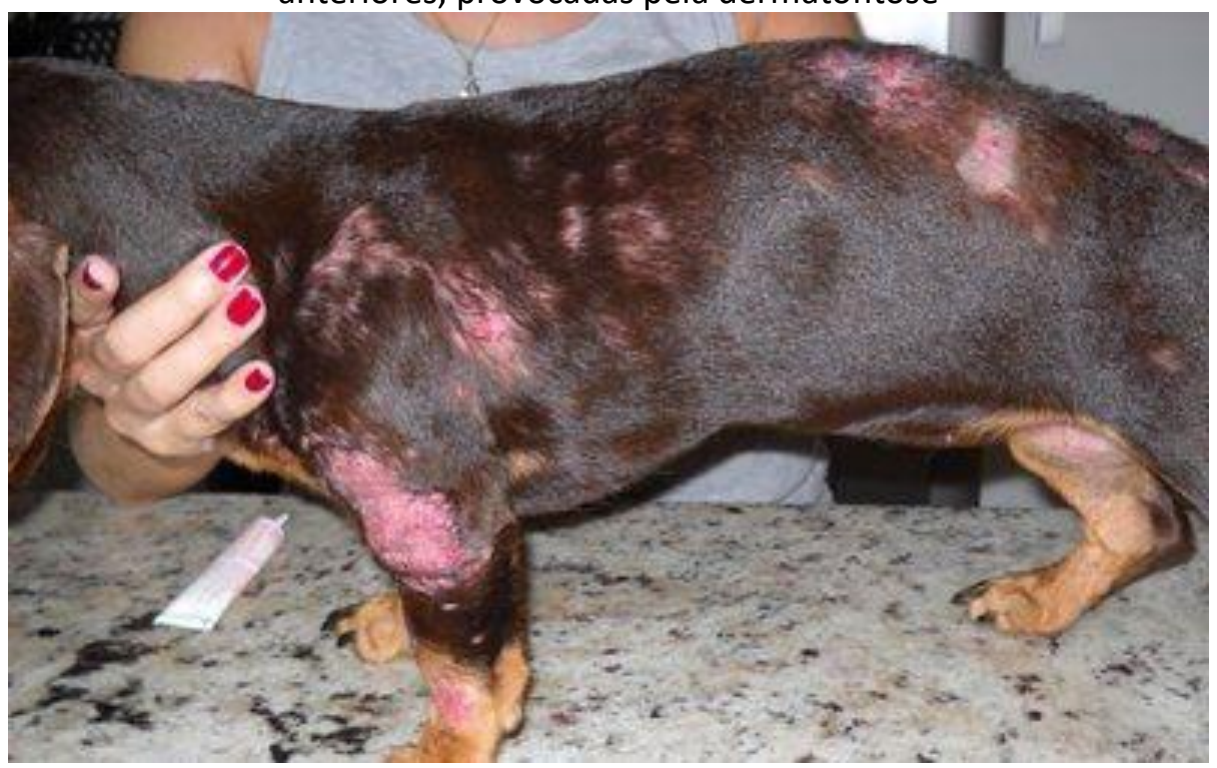

Fonte: (ONEVET, 2019).

Um estudo feito por Ceconi (2018), indicou que as lesões mais encontradas durante o diagnóstico de dermatofitoses são: descamação (45\%), eritema (57,5\%), crostas melicéricas ou hemorrágicas $(67,5 \%)$ e alopecia (100\%). Essas lesões podem ser multifocais ou localizadas apenas na região contaminada, variando de acordo com os cuidados higiênicos com o animal nesta fase (MENDOZA et al., 2009). 
Figura 6 - Cão com múltiplas lesões alopecias circulares no dorso, provocadas por dermatofitose.

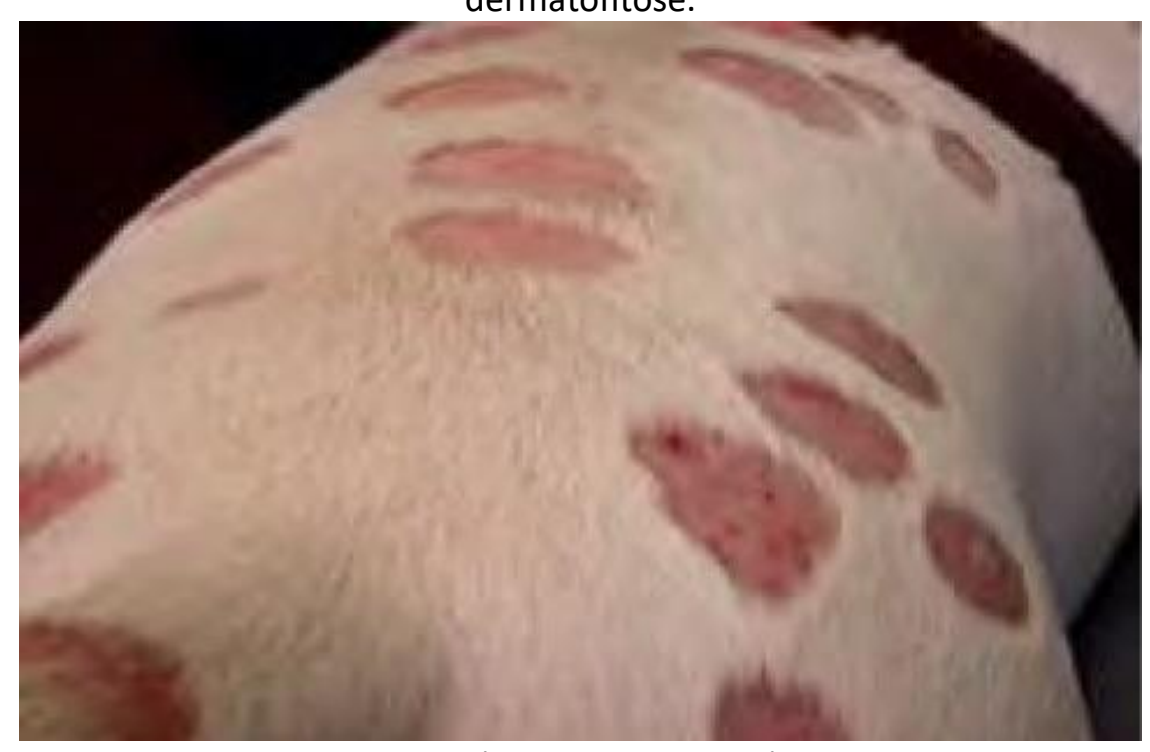

Fonte: (IMUNOCAN, 2017)

Em um estudo realizado por Cavalcante $(p .06,2006)$

Em cães, as lesões dermatofíticas podem consistir de combinações de pápulas, pústulas, com alopecia focal ou dispersa, apresentando zonas eritematosas, descamação e crostas. Reações de Quérion podem ser visualizadas geralmente na face, podendo muitas vezes mimetizar piodermites ou furunculoses.

As reações de Quérion também chamadas de dermatofitose nodular são provocadas em recorrência a processos inflamatórios agudos, ocasionando hipersensibilidade, nódulos edematosos, circulares e alopecias, com lesões profundas, que podem ser granulomatosa ou piogranulomatosa (FERREIRA et al., 2006).

\subsection{Diagnóstico}

Para que o médico veterinário realize o diagnóstico dessa doença, alguns procedimentos durante a avaliação são necessários, como: anamnese, exame físico com inspeção cutânea, exame com Lâmpada de Wood, colheita do espécime clínico, exame microscópico direto e cultura fungica (FIGUEIREDO et al., 2015).

Um exame clínico criterioso, se faz fundamental para diagnosticar a dermatofitose. Para tanto, se faz necessário a realização sequencial dos procedimentos descritos acima. Uma anamnese elaborada te direcionará para a avaliação física (auscultação, palpação, inspeção e percussão), tendo em vista que na dermatofitose, os 
sinais clínicos são visíveis na pele, de fácil percepção durante o exame físico (ANDRADE; ROSSI, 2019).

O diagnóstico de dermatofitose apenas na fase do exame físico através da inspeção cutânea (sinais clínicos, localização das lesões, presença de um fungo específico) é muito difícil, pois existem outras dermatopatias que apresentam a mesma sintomatologia que essa, podendo dificultar a detecção da real doença. Uma característica que geralmente ocorre nos casos de dermatofitoses são as alopecias circulares, eritematosas com descamações, iniciando assim, as suspeitas para o diagnóstico da mesma, a ser realizado nas seguintes fases (RHODES; WERNER, 2014).

Um exame que também pode ser utilizado para a detecção das dermatofitoses caninas é a lâmpada de Wood criada pelo Robert W. Wood em 1903. Esse teste, indica através da fluorescência nos pelos infectados, por meio da presença de pteridina uma substância secretada pelos dermatófitos. Esse exame apresenta um resultado rápido, porém, por ora poderá ser contraditório em decorrência de inexperiência e intercorrências de substâncias externas (BOND, 2010).

Uma vez que o diagnóstico clínico de dermatofitose canina não é totalmente confiável, métodos laboratoriais de diagnóstico são recomendados, a fim de promover um resultado fidedigno, destacando-se o exame microscópico direto e a cultura fungica, a partir destes é possível a realização de vários testes, para a confirmação da doença (CANAVARI et al., 2017).

Um método laboratorial que também pode ser utilizado é o exame direto com a microscopia dos pelos e escamas, do hospedeiro. Porém esse método pode apresentar falso-negativos, e não é possível distinguir a espécie. A amostra deve ser retirada com uma pinça ou lâmina de bisturi flambada e depositada em receptáculo, no laboratório, a amostra é colocada em lâminas estéreis com hidróxido de potássio, aquecida através do bico de Bunsen e realizada a análise microscópica (BAPTISTA, 2015).

Para o diagnóstico da dermatofitose também pode ser executado o isolamento primário dos fungos em meios de cultura com Agár Sabouraud mais cloranfenicol para não haver o crescimento de bactérias ou Ágar Sabouraud com cloranfenicol e cicloeximida para inibir bactérias e fungos oportunistas, onde são semeadas escamas e alíquotas de pelos incubados em temperatura em média de 25 a $28^{\circ} \mathrm{C}$ e analisadas em um período de quinze dias, para que ocorra o reconhecimento do agente etiológico 
dessa micose e suas características morfológicas (relevo, textura, pigmentação) (FERNANDES, 2013).

A partir do isolamento primário dos fungos podem ser obtidos outros estudos microscópicos para que sejam identificadas características estruturais microscópicas dos dermatófitos e diferenciá-los dentre os gêneros e espécies existentes (CHAVES, 2007).

O Dermatophyte Test Medium (DTM) é um método comercial acessível para a prática veterinária, que possibilitada o crescimento de dermatófitos. Os dois meios de cultura desse método que permite identificar os fungos, são: o ágar DTM, um meio de coloração amarela intensa e indica positivo através da alcalinização do ph, alterando a cor para vermelho. Outro meio é o Agar Sabouraud com glicose, que possibilita o crecimento de dermatófitos e de leveduras, onde as colônias aparecerão de uma a quatro semanas (BOND, 2010).

Outro teste a ser praticado é da perfuração de pelo in vitro com a finalidade de averiguar se o microrganismo possui a capacidade de degradar a queratina, usando a mesma como fonte de energia, é realizado em placa de Petri com ágar batata, o meio é incubado em temperatura de 25 a $28^{\circ} \mathrm{C}$, por um período de sete a quarenta dias e analisado semanalmente os fios de pelo, após a coloração com lactofenol azul-algodão (CHAVES, 2007).

Além desses, há também o teste de urease que verifica a presença desta enzima, feito a partir da semeadura das colônias de dermatófitos em tubos com ágar-ureia de Christensen, incubado em temperatura de 25 a 28 으 por 4 dias, em casos de mudança na coloração do método de amarelo para rosa-escuro, é apontado como positivo (SILVA, 2013).

A prova de requerimentos vitamínicos usado para definir as diferentes espécies de dermatófitos, quando os mesmos apresentarem caraterísticas micromorfologicas e macromorfologicas semelhantes, sendo analisado as exigências nutricionais de cada espécie, a partir da repicagem da cepa nos meios ágares Trichophyton (BAPTISTA, 2015).

\subsection{Tratamento}

Estudos apontam que a longo prazo a dermatofitose poderá ser eliminada sem tratamento, entretanto, para evitar os danos (aumento das lesões, disseminação 
exacerbada) provocados por essa enfermidade, devem ser realizados os seguintes tratamentos: tópico e sistêmico (LOPES; DANTAS, 2016).

O tratamento tópico tem uma duração de, em média, dois meses e algumas medidas devem ser tomadas para garantir o seu êxito. Prescreve-se a utilização de pomadas e loções antifúngicas, como: o cetoconazol, miconazol e clotrimazol, além de antibióticos e anti-inflamatórios que podem ser por via tópica - por meio de banhos com sais - ou oral - este último para casos mais graves. Após a estagnação da doença, ainda é indicado o uso de xampus a base de clorexidine. Além das medicações indicadas, a higiene e cuidado com o local das feridas é crucial, por isso, indica-se cortar o pelo do animal nas áreas lesionadas (MATTEI, 2009).

Alguns estudos apontam que o banho inicial para a descontaminação não é obrigatório, visto que seria uma forma de aumentar a disseminação das lesões, em contrapartida, outros estudos indicam que a remoção das sujidades da pelagem do animal, antes do início do tratamento (GAMITO, 2009).

Quando apenas o tratamento tópico não elimina a dermatofitose devido a intensidade das lesões (generalizadas e crônicas), se faz necessário a introdução da terapia sistêmica. Realizada por meio do uso oral de antifúngicos, como: o cetoconazol (5-10 mg/kg a cada 12 horas ou $10-20 \mathrm{mg} / \mathrm{kg}$ a cada 24 horas), fluconazol (2,5 - 5 $\mathrm{mg} / \mathrm{kg}$ a cada 12 horas ou $5-10 \mathrm{mg} / \mathrm{kg} / \mathrm{dia}$ ), terbinafina (em média de $10-40 \mathrm{mg} / \mathrm{kg} / \mathrm{dia}$ durante 2 a 4 semanas) (LANA et al., 2016).

Entretanto, não se deve administrar os antifúngicos sistêmicos, em casos de fêmeas gestantes, animais com idade menor que 12 semanas. Além disso, esses podem provocar: vômitos, diarreia, anorexia, hepatopatias, alterações gastrintestinais, devendo ser monitoradas durante o tratamento (GAMITO, 2009).

\subsection{Profilaxia}

Diante do exposto, se faz necessária a prevenção e controle da dermatofitose canina já que ela é contagiosa e devido o contato dos cães com os seres humanos estes ficam expostos a essa contaminação. Alguns cuidados com esses animais são importantes, evitar o contato com animais desconhecidos ou que estejam contaminados, além de medidas higiênico-sanitárias do animal, principalmente a 
secagem do pelo para evitar as condições que favorecem o aparecimento da doença (LOPES; DANTAS, 2016).

Já o tratamento ambiental tem o objetivo garantir que não ocorra disseminação e contaminação de pessoas e animais, já que o contato com o ambiente infectado pode acarretar essa doença em indivíduos ou animais sadios. Diante disso, devem ser tomadas medidas higiênico-sanitárias e isolamento dos contaminados para que não se tornem reservatórios fúngicos (NEVES, 2011).

Os cuidados profiláticos são realizados através de ações higiênico-sanitárias adequadas como a desinfecção (com álcool 70\% e hipoclorito de sódio 1\%) de superfícies de contato como: pisos, instalações, utensílios, tapetes, toalhas, cobertores e outros objetos dos animais e humanos para se evitar a contaminação dos mesmos e o isolamento de animais infectados (LOPES; DANTAS, 2016).

Além da técnica de desinfecção descrita acima, para evitar a propagação podem ser realizados outros procedimentos, como a aspiração dos pelos dos animais, limpeza doméstica com lixívia com diluição de 1:10 por 10 minutos e aplicação de spray de enilconazol e imaverol (GAMITO, 2009).

Também é importante prevenir a doença por meio de vacina, responsável por deixar o organismo do cão mais forte, combatendo mais facilmente à infecção do fungo. É essencial, também, que o pelo do animal seja higienizado e seco. E não permitir que ele tenha contato com outro do qual não se sabe a procedência (PALUMBO et al., 2010).

Essas vacinas possuem antígenos capazes de combater o fungo M. canis, com três doses com intervalos de quatorze dias, aplicada de forma intramuscular em caninos, além, das doses preventivas indicadas a partir dos três meses de idade e a vacina anual, sendo que, a vacina mais utilizada na prática clínica é a Biocan $M$, com dosagem de $1 \mathrm{ml}$ por animal, de acordo com a (figura 7) (MATTIE, 2009). 
Figura 7 - Vacina Biocan M, utilizada no combate a dermatofitose

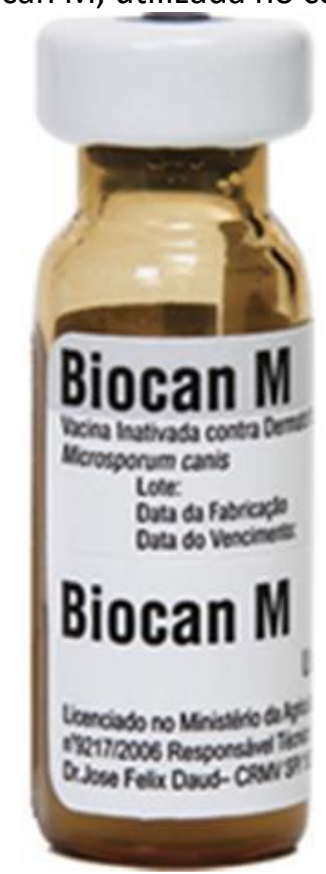

Fonte: INTERSUL, 2019.

\section{CONSIDERAÇÕES FINAIS}

A dermatofitose é uma micose fungica que atinge tanto os cães quanto outros animais, quanto os seres humanos que mantém contato com esses animais infectados. Devido sua grande frequência de multiplicação, vem sendo objeto de vários estudos. Essa infecção é causada por fungos dermatófitos, em especial os do gênero Microsporum gypseum; Microsporum canis; Trichophyton mentagrophytes. E provocando lesões na pele e nos pelos destes animais e humanos.

O controle e a prevenção são indispensáveis, visto que essa patologia vem aumentando significativamente, devido ao contato íntimo dos seres humanos com os animais domésticos. O diagnóstico preciso, evitará maior contaminação de outros animais e eventualmente maiores danos. Sendo assim, o médico veterinário é o responsável por realizar este diagnostico, através de estratégias e exames clínicos que possam identificar os dermatófitos e assim prescrever o tratamento adequado.

Portanto, é de extrema importância que o Médico Veterinário tenha conhecimentos acerca dessa doença, principalmente em relação aos diagnósticos, tratamentos e prevenção, para que o animal seja diagnosticado corretamente, estabelecer o tratamento adequado e informações seguras para os donos, evitando uma disseminação dessa doença. 


\section{REFERÊNCIAS}

ANDRADE, V.; ROSSI, A. M. Dermatofitose Em Animais De Companhia E Sua Importância Para A Saúde Pública - Revisão De Literatura. Revista Brasileira de Higiene e Sanidade Animal, v.13, n.1, p.142-155, jan./mar. 2019.

BAPTISTA, Edilene Bolutari. Estudo de Estabilidade e Eficácia de Formulação Tópica Fitoterápica para Tratamento de Dermatofitose Animal. 2015. 175 f. Tese (Doutorado em Ciências da Saúde) - Universidade Federal de Juiz de Fora.

BOND, R. Superficial veterinary mycoses. Clinics in Dermatology. Clinics in Dermatology, v. 28, n. 2, p. 226-236, 2010.

BOHJANEN, K. Dermatologia Clínica. Elsevier, São Paulo, 5 ed. cp.01, p.1056, 2013.

CANAVARI, I.C. et al. Doenças Dermatológicas de Caráter Zoonótico. Investigação, v. 16, n. 1, p. 18-24, 2017.

CAVALCANTE, C. S. P. Caracterização Das Dermatofitoses Canina E Felina E Manutenção De Cepas Dermatofíticas In Vitro. 2006. 90 f. Dissertação (Mestrado em Ciências Veterinárias) - Universidade Estadual do Ceará.

CECONI, J. E. et al. Avaliação dos Tratamentos Farmacológicos para Dermatofitoses em Animais de Companhia. PubVet, Paraná, v. 12, n.4, p.1-10, abr. 2018.

CHAVES, L. J. Q. Dermatomicoses Em Cães E Gatos: Avaliação Do Diagnóstico ClínicoLaboratorial E Dos Aspectos Epidemiológicos Em Uma População De Portadores De Lesões Alopécicas Circulares. 2007. 88 f. Dissertação (Mestrado em Ciências Veterinárias) - Universidade Estadual do Ceará.

FERNANDES, S. et al. Kerion caused by Microsporum audouinii in a child. Med Mycol Case Rep. V. 02, n.53, p. 52-54, 2013.

FERREIRA, R. R. et al. Quérion causado por Microsporum Gypseum em um cão. Acta Scientiae Veterinariae, v.34, n.1, p.179-182, 2006.

FIGUEIREDO, K. B. et al. Dermatofitose canina. Clínica Veterinária, v.49, n. 01, p. 20-28, 2015.

FRAGA, C. F. Dermatófitos Em Gatos Sem Dermatopatias Na Região Metropolitana de Florianópolis - Sc. 2017. 53 f. Dissertação (mestrado em medicina veterinária) Universidade Federal do Rio Grande do Sul.

GAMITO, M. S. R. Dermatites Parasitárias no Cão. 2009. 89 f. Dissertação (Mestrado em Medicina Veterinária) - Universidade Técnica de Lisboa. 
GADO, S. C. Alamy, 2019. Disponível em: <https://www.alamy.it/foto-immagine-questae-una-microfotografia-del-fungo-microsporum-gypseum-utilizzando-il-cotonelactophenol-blu-tecnica-di-colorazione-il-dermatophyte-m-gypseum-unterreno-naturale-habitant-puo-causare-tinea-corporis-tinea-capitis-negli-esseriumani-e-negli-animali-1969-altri-funghi-filamentosi-sono-inclusi-nei-generiepidermophyton-e-trichophyton-immagine-cortesia-cdcdott-leanor-haley169015566.html?

IMUNOCAN. Vacina para Tratamento e Prevenção de Dermatofitose em Cães e Gatos, 2017. Disponível: < https://grascon.com.br/imunocan/>. Acessado em: 12 mai. 2019.

INTERSUL. BIOCAN M VACINA AMPOLA 1ML, 2019. Disponível em: < http://www.intersulvet.com.br/prd/biocan-m-vacina-ampola-1ml>. Acessado em: 22 jun. 2019.

LANA, D. F. D. et al. Dermatofitoses: agentes etiológicos, formas clínicas, terapêutica e novas perspectivas de tratamento. Clínica Biomédica, Rio Grande do Sul, v. 4, n. 36, p.230-241, set. 2016.

LOPES, C. A.; DANTAS, W. M. F. Dermafitose Em Cães E Gatos- Revisão De Literatura. Anais VIII SIMPAC, Viçosa, v.08, n.01, p. 292-297, jan./dez. 2016.

MADRID, I. M. et al. Dermatofitose Neonatal Canina por Microsporum Gypseum. Veterinária e Zootecnia, Rio Grande do Sul, v.19, n.1, mar. 2012.

MATTEI, A. S. Diagnóstico De Dermatofitose Em Pequenos Animais: Um Estudo Retrospectivo Na Região Sul Do Rio Grande Do Sul. 2009. 30 f. Monografia (Especialização em Análises Clínicas em Veterinária) - Universidade Federal do Rio Grande do Sul.

MATTEI, A. S.; BEBER, M.A.; MADRID, I.M. Dermatophytosis in small animals. SOJ Microbiology \& Infectious Diseases, v. 2, n. 3, p. 1-6, 2014.

MENDOZA, M.H. et al. A zoonotic ringworm oubreak caused by a dysgonic strain of Microsporum canis from stray cats. Revista Iberoamericana de Micologia, v.27, n.2, p.62-65, 2009.

MEDEIROS, F.; CREPALDI, Nadyne; PERES, Rosa Elisabeth. Dermatófitos - Revisão de Literatura. Revista Científica Eletrônica De Medicina Veterinária, Garça, v. 5, n. 12, p.132-157, jan. 2009.

MOURA, R. S. Evolução do Mercado Pet e as Exportações Brasileiras no Setor. 5ạ Jornada Científica e Tecnológica da FATEC, Botucatu, 2016. 
NEVES, R. C. S. M.; CRUZ, F. A. C. S.; LIMA, LIMA, S. R.; TORRES, DUTRA, V.; SOUSA, V. R. F. Retrospectiva das dermatofitoses em cães e gatos atendidos no Hospital Veterinário da Universidade Federal de Mato Grosso, nos anos de 2006 a 2008. Ciência Rural, Santa Maria, v.41, n.8, p. 1405-1410, ago. 2011.

OLIVEIRA, L. M. B. et al. Dermatofitose Canina Causada pelo Fungo Antropofílico Trichophyton tonsurans - Relato de caso. Revista Brasileira de Higiene e Sanidade Animal, Ceará, v.9, n. 1, p. 91-98, 2015.

OLIVEIRA, W. N. k. et al. Diagnóstico Clínico De Dermatofitose Canina Causada Por Trichophyton Mentagrophytes- Relato De Caso. PubVet, 2013.

ONEVET. Dermatofitose (Tinha), 2019. Disponível em: <http://www.onevetgroup.pt/cuidar/?Contentld=6344>. Acessado em: 22 jun. 2019.

PALUMBO, M. I. P. et al. Estudo Epidemiológico das Dermatofitoses em Cães e Gatos Atendidos no Serviço de Dermatologia da Faculdade de Medicina Veterinária e Zootecnia da UNESP - Botucatu. Semina: Ciências Agrárias, Londrina, v.31, n.2, p.459-468, abr./jun. 2010.

PRADO, M. R. Isolamento De Microsporum Canis, Malassezia Spp. E Candida Tropicalis Em Cães: Um Destaque Para Teste De Sensibilidade De Malassezia Pachydermatis In Vitro. 2007. 159 f. Monografia (Especialização em Ciências Veterinárias) - Universidade Estadual do Ceará.

REZENDE, C.; BORSARI, G.P; SILVA, A.C.F; CAVALCANTE, F.R. Estudo epidemiológico das dermatofitoses em instituições públicas da cidade de Barretos, São Paulo, Brasil. Rev Bras An Clin., v.40, n.1, p.13-16, 2008.

RHODES, K. H.; WERNER, A. H. Dermatoses Infecciosas. In: RHODES, K. H.; WERNER, A. H. Dermatologia de Pequenos Animais. Roca, Rio de Janeiro, 2a ed., p. 632, 2014.

SILVA, N. Cadernos Técnicos De Veterinária E Zootecnia. Dermatologia em cães e gatos. Revista FEPMVZ, Minas Gerais, 2013.

SILVA, R. R.; COELHO, G. D. Fungos: Principais Grupos e Aplicações Biotecnológicas. Instituto de Botânica, São Paulo, v.5, n.1, p.40-60, out. 2006.

SILVA, V. F. et al. Agentes Fúngicos da Dermatofitose em Cães e Gatos do Município de Xanxerê, Santa Catarina. Semira: Ciências Agrárias, Londrina, v. 32, n. 3, p. 10951100, jul./set. 2011.

SOUZA, A. E. F. et al. Dermatofitose associadas a fungos do gênero Microsporum. Clínica Veterinária, São Paulo/SP, v. 13, n. 5, p. 24-26, 2012. 


\section{CAPÍTULO IX}

\section{DOENÇA DE MAREK - ASPECTOS EPIDEMIOLÓGICOS}

DDI: 10.51859/amplla.pdi443.1121-马

Flávia da Costa Garcia ${ }^{1}$

Emília da Costa Garcia ${ }^{2}$

Fabrício Eumar de Sousa ${ }^{2}$

Cristielle Nunes Souto ${ }^{2}$

Eric Mateus Nascimento de Paula ${ }^{2}$

${ }^{1}$ Médica Veterinária Autônoma. Egressa do Curso de Medicina Veterinária do Centro Universitário de Mineiros UNIFIMES

${ }^{2}$ Docente do Curso de Medicina Veterinária do Centro Universitário de Mineiros - UNIFIMES.

\section{RESUMO}

A Doença de Marek é uma alteração linfoproliferativa de aves, provocada por um vírus da família Herpesviridae, caracterizada por acometer células musculares músculos, da pele, vísceras, íris, gônodas e nervos periféricos. Este trabalho trata-se de uma revisão de literatura em que se descreve as principais características epidemiológicas da Doença de Marek. Na ocasião em que as barreiras sanitárias estão com maior exigência, recomendando novos sistemas para criação das aves, este estudo demostra a importância de saber mais sobre esta enfermidade e com isso compreender que no ambiente sanitário é fundamental a execução eficiente de programas de biossegurança. Com um conhecimento melhor desta enfermidade pode-se detectá-la de forma precoce e antecipar as ações de controle e prevenção, evitando assim prejuízos nas indústrias avícolas.

Palavras-chave: Avicultura. Epidemiologia. Mardivirus. Ornitopatologia.

\section{INTRODUÇÃO}

Em meio a performance que o agronegócio brasileiro contém, a avicultura industrial desempenha função notória e possui níveis elevados na produtividade, sobretudo devido à tecnificação. As condições climáticas adequadas, vasta extensão territorial, grande mercado consumidor, baixo custo de produção devido a abundância de insumos como grãos, sistema de integração consolidado, indústrias modernas disponibilidade de mão-de-obra, faz com que o país possua características cruciais que permitem o desenvolvimento da produção aviária. 
Independente do sistema de produção escolhido, a saúde das aves está relacionada à aplicação de bom mecanismo de manejo, e investimentos em nutrição é fundamental para que a produção avícola continue avançando e para que a potencialidade das aves seja ao máximo aproveitado.

O crescimento da avicultura aumenta a exigência por tecnologias e se não realizadas de forma correta, resulta em uma maior susceptibilidade aos agentes patogênicos. Essa exposição ao agente, aliada aos erros de manejo podem levar à uma imunossupressão da atividade do sistema imunológico. Pois a criação de aves de forma exacerbada beneficia a disseminação do vírus entre os animais. No caso de enfermidades imunossupressoras de caráter infeccioso, a doença de Marek está entre as de maior destaque.

A Doença de Marek é uma doença linfoproliferativa altamente infecciosa que afeta principalmente galinhas, causada por um herpes vírus é caracterizada pela infiltração de células em um ou mais dos nervos periféricos, nas gônadas, íris, vísceras, músculo e pele. O agente etiológico dessa enfermidade está distribuído na maioria dos países criadores de aves e certamente, todos os lotes de aves passam por algum dano causado pela doença. No Brasil o diagnóstico tem sido tanto em matrizes quanto em aves para abate e em poedeiras.

O objetivo desse trabalho foi realizar um levantamento bibliográfico sobre a enfermidade de Marek, visto sua importância para a avicultura, e assim abordar os principais aspectos epidemiológicos com o intuito de esclarecer as melhores formas de controle e prevenção para evitar os índices de prevalência e incidência.

\section{REVISÃO DE LITERATURA - DOENÇA DE MAREK}

\subsection{Definição}

Identificada pela infiltração de células um ou mais dos nervos periféricos, gônadas, íris, vísceras, músculos e pele a DM causada por um Herpesviridae, é uma doença linfoproliferativa altamente infecciosa que afeta principalmente galinhas (Gallus gallus domesticus). Tendo como sinal clínico particular a paresia uni ou bilateral das pernas (BARBOSA e CANAL, 2009; NAIR e SCHAT; 2013). 
$\mathrm{Na}$ indústria avícola essa doença tem um impacto econômico extenso, pelo aumento da mortalidade, condenação de carcaça, custos de vacinação e perda na produção de ovos (LANDMAN e VERSCHUREN, 2003; SCHAT e WITTER; 2003; NAIR e SCHAT; 2008). A criação intensiva de aves beneficia uma rápida disseminação do vírus provocando assim à infecção dos animais por inalação da poeira contaminada com o vírus (FRANCO; ROEHE; VARELA, 2012).

\subsection{Histórico}

O primeiro relato da doença foi feito em 1907 na Hungria pelo patologista médico veterinário József Marek. que observou a paralisia de asas e pernas de galos e relacionou à uma ação inflamatória de nervos periféricos, inicialmente designando-a de polineurite. Posteriormente, essa doença foi renomeada em consideração ao médico veterinário que descobriu a enfermidade (SILVA, 2016).

Em 1914 nos EUA, Nova Zelândia, Grã-Bretanha, Holanda e vários outros países foram reconhecidos surtos da doença. Durante o século XX quando a avicultura industrial apresentava um crescimento significativo, foi quando a doença alcançou maior importância (NAIR e SCHAT, 2008; BARBOSA e CANAL, 2009).

Alguns anos depois descobriu-se que os tumores linfoides compreendiam uma enfermidade infecciosa causando lesões nos nervos periférico e gânglio espinhal assim como as neoplasias linfoides dos ovários e acometendo outros órgãos viscerais (SCHAT e WITTER, 2003).

\subsection{Agente etiológico}

Pertencente à família Herpesviridae da subfamília Alphaherpesvirinae do gênero Mardivirus, ou simplesmente vírus da doença de Marek (VDM) (BAATEN, BUTTER e DAVISON 2004). Esse vírus possui DNA de fita dupla apresentando um genoma linear, composto por volta de 160 a 180 mil pares de bases. O VDM possui um envelope lipídico e mesmo sendo sensível a maior parte dos desinfetantes e detergentes ele apresenta grande resistência e longevidade no meio ambiente. Podendo sobreviver em temperatura ambiente por 16 semanas, no entanto em temperaturas mais baixas mostra uma resistência, em sistemas de criação com ambientes fechados a doença pode agravar durante o inverno (TULMANN et al., 2000; OIE, 2010). 
São descritos na literatura três sorotipos do VDM. O sorotipo 1 (oncogênico) abrange as amostras virulentas do vírus e algumas cepas de vacina. O sorotipo 2 (não oncogênico) compreende o vírus de galinhas clinicamente normais. E o sorotipo 3 (não oncogênico) é comum em perus, sendo cepas mais utilizados para a produção de vacinas contra a doença de Marek em galinhas (BAATEN, BUTTER e DAVISON 2004).

As amostras do sorotipo 1 são divididas em quarto patotipos de acordo com a sua capacidade de causar neoplasias, sendo elas: cepas de baixa patogenicidade, cepas de baixa virulência, cepas de alta virulência, já os danos prolongados ou definitivos dos tecidos podem ser causados devido a cepa de altíssima virulência (SCHAT e WITTER, 2003).

\subsection{Epidemiologia}

Em 1914 nos EUA, Nova Zelândia, Grã-Bretanha, Holanda e vários outros países foram reconhecidos surtos da doença (NAIR, e SCHAT, 2008; BARBOSA e CANAL, 2009). No Brasil o VDM tem ocorrido em matrizes, poedeira e frangos de corte. Presente em todos os países do mundo, o crescimento da produção associado a modernização da indústria avícola requer uma atenção maior à saúde dos viveiros, pois a produção de frangos ocorre normalmente em sistemas intensivos, concentrando muitas aves em uma determinada área. Tornando-se assim propício para a disseminação, perpetuação e multiplicação de vários patógenos levando a um episódio de surtos de enfermidades gerando prejuízos econômicos a indústria avícola (SESTI, 2004).

De acordo com Torres (2017) citado por Abreu et al, (2016) foi diagnosticado casos de DM em uma propriedade em Carabepeus no município do Rio de Janeiro com criação de sistema extensivo, mesmo as aves sendo vacinas no primeiro dia de vida. $\mathrm{A}$ utilização de medidas sanitárias mostra que é preciso adotar todas as medidas de controle e prevenção, pois a vacinação por si só não controla a doença.

Já em relação a cadeia epidemiológica temos que as aves podem ser portadoras do VDM, espalhando-o permanentemente nas instalações. Um dos principais meios de transmissão são penas e as fezes, que perduram infectando por meses os galpões. A eliminação do VDM ao ambiente se dá após sua entrada no organismo animal podendo ter início a partir da segunda (SCHAT e WITTER, 2003; SILVA, 2016). 
O VDM dispõe de um mecanismo de se espalhar na natureza, os hospedeiros são contaminados independentemente da imunidade vacinal ou presença de anticorpos maternos e desenvolve uma latente resistente a infecção. Muitas galinhas tornam-se portadoras assintomáticas pois não apresentam sinais clínicos característicos do DM, transmitindo o vírus ininterruptamente para outras aves continuando persistente durante todo o ciclo de vida (WITTER 2000; SCHAT e WITTER, 2003; OSTERRIEDER et al., 2006; BARBOSA e CANAL, 2009; OIE, 2010; MOREIRA, SANTOS, DIAS 2008; NAIR e SCHAT 2013).

O vírus vai se replicar pela primeira vez no folículo das penas, durante a nova formação de empenamento vai ocorrer uma descamação de células epiteliais, essas células infectadas vão contaminar o ambiente. Isto contribui para uma contínua contaminação do galpão durante vários meses Parte da poeira do galpão é composta por células descamadas vão permear nas vias respiratória através da inalação de partículas infectadas, essas partículas vão diretamente para o pulmão (BACK, 2004; SILVA, 2006; SILVA, 2016).

Embora o vírus possa persistir por longos períodos no meio ambiente, em alguma das fases de suas vidas, todas as aves acabaram tendo contato com o agente tornandose um desafio, pois os pintos infectados começam a excreta o vírus após duas semanas (SCHAT e WITTER, 2003; OSTERRIEDER et al., 2006; OIE, 2010; NAIR e SCHAT, 2013).

Após a ave ser infectada o período de transmissão do vírus será de 2-4 semanas, embora esse período possa ser por toda a vida, algumas aves podem não manifestar sinais clínicos característicos, o que as tornará portadoras assintomáticas. Além das galinhas codornas, perus e faisões também são hospedeiros susceptíveis (SCHAT e WITTER, 2003; GRIEBELER, 2005; BARBOSA e CANAL, 2009; OIE, 2010; NAIR e SCHAT, 2013).

\subsection{Patogenia}

A doença de Marek tem uma patogenia complexa e não é compreendida totalmente. A transmissão do vírus acontece por via respiratória, através da inalação de poeira contaminada com descamações de pele contendo o VDM infectante e livre de células. Após infectar os macrófagos locais, o vírus irá se replicar primeiramente nas células epiteliais do trato respiratório (NAIR e SCHAT, 2013). 
Após a infecção o VDM é transportado a partir dos pulmões sistemicamente e vai para os tecidos linfoides do timo, baço e bursa de Fabricius, após infectar os linfócitos aproximadamente 3-7 dias o vírus atinge seu pico de replicação. Uma resposta imune humoral é mediada por células durante a infecção, os anticorpos têm um papel importante na redução de níveis de infecção em pintinhos (BARBOSA e CANAL 2009).

Durante a fase citolítica o desenvolvimento de anticorpos é decisivo para o resultado da infecção. Pois durante essa fase as alterações da resposta imune vão adiar o estabelecimento da latência, estendendo a infecção, e por consequência a destruição de células imunes (SCHAT e WITTER, 2003).

Depois que ocorre a fase citolítica o VDM vai promover uma infecção latente em linfócitos, particularmente células T CD4+, e nas CD4-CD8-, CD8+ e em e linfócitos B. 0 VDM é rigorosamente associado a células, sendo assim as partículas virais são produzidas unicamente pela replicação nos folículos das penas. Após replicação do vírus no epitélio do folículo da pena, de 7-14 dias pós infecção o vírus é excretado no meio ambiente Os linfócitos $T$ das aves geneticamente suscetíveis se tornam alvos para modificações neoplásicas, e consequentemente a formação de tumores linfomatosos em órgãos viscerais (VENUGOPAL, 2000; SCHAT e WITTER, 2003; OSTERRIEDER et al., 2006; NAIR E SCHAT 2013).

A terceira fase de infecção é caracterizada por uma infecção secundária, envolvendo o sistema nervoso. São detectadas nesta fase, lesões inflamatórias. A partir do $12^{\circ}$ dia após infecção são formados linfomas malignos de linfócitos $T$, denominando assim uma quarta fase da infecção (OSTERRIEDER et al., 2006; NAIR E SCHAT, 2013).

A infecção por VDM em galinhas é decorrente de aves portadoras e disseminadoras constantes do vírus no meio ambiente. A forma de paralisia transitória provocada pela infecção do sistema nervoso central manifesta sinais clínicos neurológicos dominantes. Estirpes de alta virulência do VDM tem sido relacionado aos episódios de forma aguda da doença a qual tem se mostrado cada vez maior em ocorrência (SCHAT e WITTER, 2003; OIE, 2010).

Após a ave ser infectada o período de transmissão do vírus será de 2-4 semanas, embora esse período pode ser por toda a vida. Algumas aves podem não manifestar sinais clínicos característicos, o que as tornará portadoras assintomáticas. Com o quadro de imunocompetência vai diminuir a expressão viral o que induzirá à latência (BARBOSA 
e CANAL, 2009; OIE, 2010; NAIR e SCHAT, 2013; SCHAT e WITTER, 2003; HEIDARI et al., 2010).

\subsection{Sinais Clínicos}

Para Schat e Witter (2003) a doença apresenta-se como clássica ou aguda. $\mathrm{Na}$ clássica 8-12 dias após a exposição as aves vão apresentar sinais como: ataxia, paralisia flácida de membros e pescoço. Esses sinais podem permanecer por 1-2 dias as aves podem apresentar uma completa e rápida recuperação, no entanto poucas semanas depois por causa dos linfomas elas podem sucumbir. Já na forma aguda após o início dos sinais de paralisia as aves morrem entre $24-72$ horas.

Há alteração dos nervos periféricos, pode estar acompanhada de paralisia completa de uma ou mais terminações como mostra a (figura 1). O comprometimento do nervo vago pode provocar alterações do papo. Normalmente os primeiros sinais notados são as posturas incomuns e incoordenação das aves (CANAL e SILVA, 2000).

Figura 1 - Paralisia resultante de processo inflamatório nos nervos periféricos de corrente de infecção pelo vírus da Doença de Marek

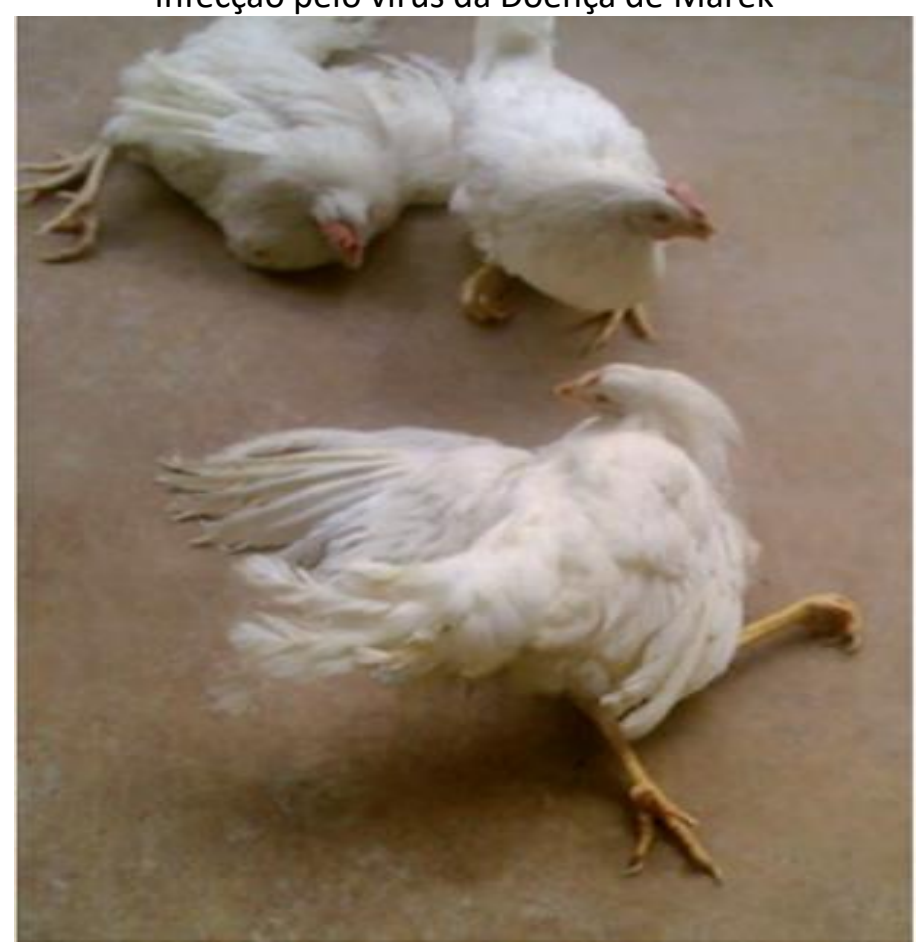

Fonte: SILVA (2016).

É também associada à contaminação da inervação ocular que é capaz de provocar cegueira com o comprometimento da íris e perda da capacidade de adaptação 
a vivacidade da luz. A pupila pode se modificar e, em fases avançadas, torna-se apenas um pequeno ponto (BARBOSA e CANAL, 2009).

Em aves em que o curso da doença é prolongado são observados sinais clínicos não específicos como anorexia, perda de peso, diarreia. Por não conseguirem se locomover até os bebedouros e comedouros essas aves sofrem um quadro de desidratação levando a morte (SCHAT e WITTER, 2003).

Maior incidência da doença e mais linfomas viscerais estão relacionadas com cepas de surtos agudos. A mortalidade precoce, paralisia transitória e sinais clínicos são reduzidos pelos anticorpos maternos. A severidade da DM é ocasionada por alta concentração de aves, fatores ambientais, infecções intercorrentes e micotoxinas (CANAL e SILVA 2000).

\subsection{Achados anatomopatológicos}

São observadas lesões nos nervos periféricos como gânglios e medula espinhal que se caracterizam por apresentar coloração cinza ou amarelada e perda das estrias transversais. Lesões não neoplásicas: são lesões degenerativas da medula óssea e vísceras, lesões de pele: provocam ruptura da pele, tumores linfoides: são encontrados em qualquer lugar, principalmente nos rins, fígado, pulmão, coração, gônadas e Bursa de Fabrício (SCHAT e WITTER, 2003).

Figura 2 - ave macho, nervo isquiático, lado direito mais espesso se comparado com o direito, o nervo isquiático apresentava infiltrado de linfoblastos, linfócitos pequenos, médios, plasmócitos e macrófagos, polimorfismo 


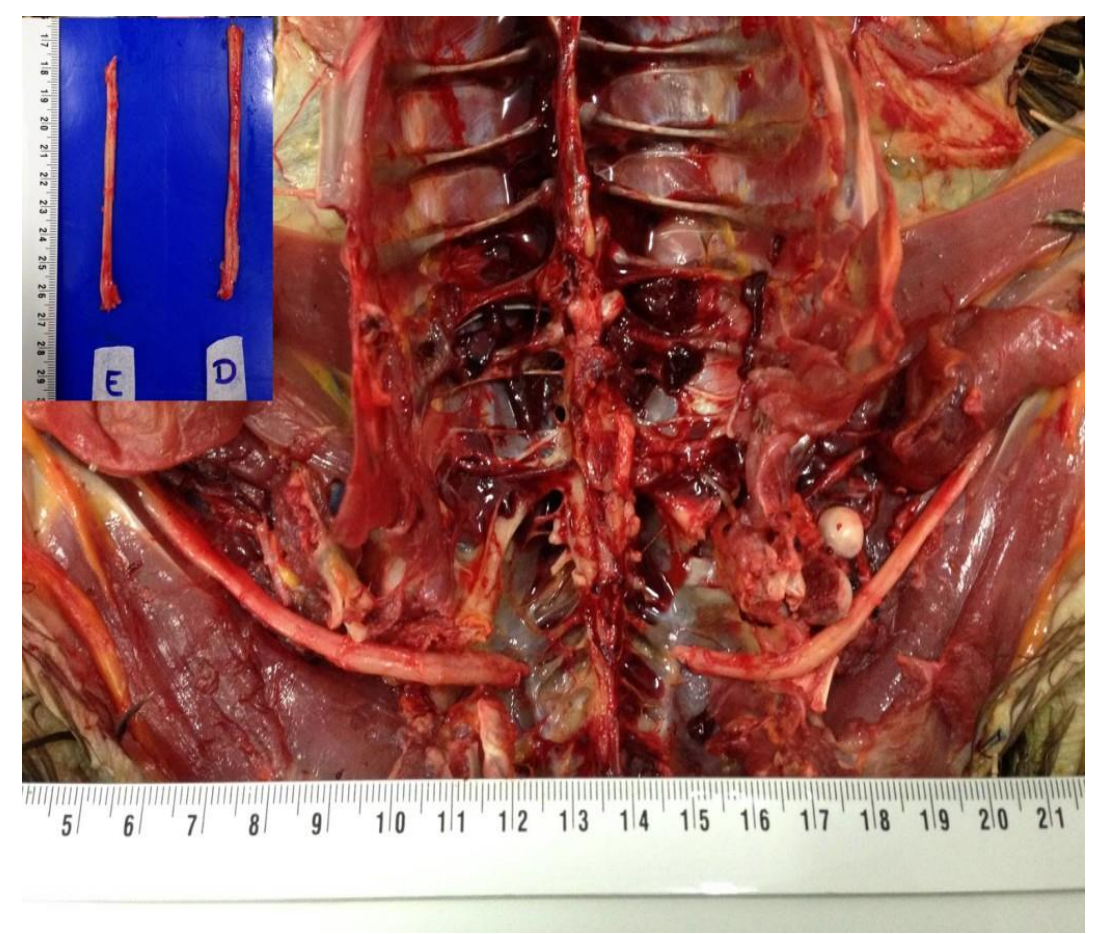

Fonte: SILVA (2016).

Figura 3 - ave macho, nervo ciático, lesão linfoproliferativa multifocal acentuada

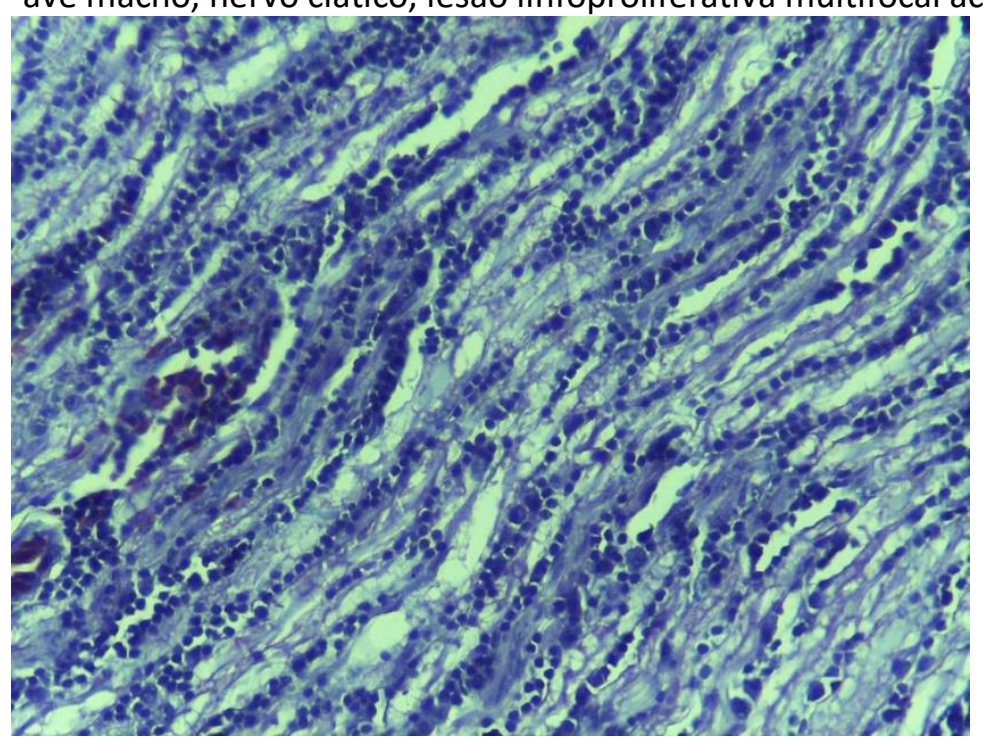

Fonte: SILVA (2016).

\subsection{Diagnóstico}

Baseia-se nos sinais clínicos, achados anatomopatológico, epidemiologia. As lesões mais sugestivas da DM são: descoloração da íris, irregularidade da pupila, tumores linfoides sem o envolvimento da bursa de Fabricius em aves com mais de 16 semanas. Aves com menos de 16 semanas apresentarão tumoreslinfoides no fígado, coração, gônada, pele, músculos e proventrículo (SCHAT e WITTER, 2003). Exame histológicos devem ser incluídos, pois este aponta uma mista população de linfócitos grandes e pequenos, plasmócitos, macrófagos e plasmócitos em tumores na DM. Os 
tumores e os tipos de células vão variar com a virulência do vírus e o estágio da doença (SCHAT e WITTER, 2003).

Exames laboratoriais como PCR e imunohistoquímica são usados para detectar antígenos nas lesões e relacionar o agente com a presença dessas lesões além de efetuar o monitoramento do VDM nas populações de aves. Além disso várias técnicas laboratoriais como a detecção de anticorpos específicos através de testes de imunofluorescência, ágar gel e ELISA também são utilizados (SCHAT e WITTER, 2003; YUNYS, JAROSISKI, SCHAT, 2004; ISLAM et al., 2004; BAIGENT et al., 2005; ABDULCAREEM et al., 2006).

Para fazer a caracterização do vírus ou a produção de vacinas o vírus é isolado e multiplicado em cultivos celulares. Células de rim de galinha são usadas para fazer o isolamento do sorotipo 1 e para o sorotipo 2 e 3 usa-se o fibroblasto do embrião de galinha. O vírus tem uma resistente ligação com as células viáveis, apesar de ser encontrado em células da pele, fezes e folículo das penas (CANAL e SILVA 2000; SCHAT e WITTER, 2003).

\subsection{Diagnóstico Diferencial}

Os tecidos lesionados devem ser enviados para exames histopatológicos sendo necessário estabelecer diagnósticos diferenciais, pois as lesões da DM e sinais clínicos pode ser confundida com a Reticuloendoteliose e Leucose aviaria, o que vai diferenciar essas doenças é a idade das aves acometidas o grau e o local das lesões. Na Leucose ocorre a formação de tumores na bolsa cloacal com metástases em outros tecidos e órgãos abdominais. E na Reticuloendoteliose esporadicamente o vírus pode causar a formação de tumores de evolução lenta (BACK, 2004; NAIR e SCHAT, 2008).

\subsection{Prognóstico}

O prognostico da doença é desfavorável, após o aparecimento dos sinais clínicos os animais afetados morrem dentro de $24-72$ horas em função da caquexia pela falta de alimentação. (SCHAT e WITTER, 2003; GIMENO, 2009; OIE, 2010; SCHAT; NAIR, 2013;).

\subsection{Medidas de prevenção e controle}

Por não existir tratamento para a DM, devem ser tomadas medidas de controle e prevenção juntamente com a vacinação a qual tem o objetivo de evitar que as aves 
adoeçam ou morram e assim reduzir as perdas na produção e produtividade (CANAL e SILVA, 2000; MORAES e SALLE, 2009).

Medidas de biossegurança como a limpeza dos equipamentos, desinfecções dos galpões, remoção da cama evitando a reutilização em lotes sucessivos, evitar alojamento de aves de diferentes idades, todas essas medidas têm como objetivo evitar a contaminação e a disseminação de doenças para novos lotes. Foi um marco na medicina aviaria o desenvolvimento da vacina, pois foi a primeira vacina contra doenças neoplásicas (VENUGOPAL, 2000; SESTI, 2005).

O uso da vacina não é para prevenir a infeção, mas para precaver a formação de tumores. Apenas respostas de anticorpos são induzidos pelas vacinas inativadas. Para que haja uma proteção contra a replicação precoce do vírus virulentos nos órgãos linfoides e uma redução no nível de infecção latente faz-se o uso de vacinas com vírus vivo. Por apresentar pouca patogenicidade residual vacinas recombinantes oferecem mais vantagens (VENUGOPAL, 2000; SCHAT e WITTER; 2003).

As vacinas disponíveis apenas na forma associada a células são do sorotipo 1 e 2 ambas reduzem o nível de infecção latente e protegem contra a precoce replicação do vírus nos órgãos linfoides, embora a vacina do sorotipo 1 atenuado induz uma resposta imune mais efetiva. Já a do sorotipo 3 são disponíveis na forma livre quanto associada á célula. A exposição precoce das aves aos vírus virulentos, faz com que ocorra uma cobertura vacinal incompleta (SCHAT e WITTER; 2003; OSTERRIEDER et al., 2006; SANTOS; MOREIRA; DIAS, 2008; OIE, 2010; SCHAT e NAIR, 2013).

A vacinação é realizada de duas formas, em embriões com 18 dias com doses maiores de 1.000 unidades formadoras de placas ou via parental no primeiro dia de vida do pintinho é necessário 7 dias pós- vacinação para que haja uma imunidade estabelecida. Dessa forma apresenta proteção de 90\% (CANAL e SILVA, 2000; WAKENELL et al, 2002).

A estratégia de vacinação não foi muito eficiente em impossibilitar a evolução do vírus no sentido de maior virulência Apesar de que tenha atingido sucesso em reduzir as perdas relacionadas à doença. Alguns fatores como, estresse, idade de vacinação, local de administração, revacinação pode interferir na eficiência da vacinação (LADMAN e VERSCHUREN, 2003; NAIR et al, 2005). 
Todos esses fatores podem afetar a imunidade das aves vacinadas, tornando-as suscetíveis às infecções de campo a vacinação se torna essencial para a prevenção e controle da DM, apesar de que as práticas de biossegurança e resistência genética sejam importantes e possam assumir um papel maior devido às limitações crescentes da vacinação. $\mathrm{O}$ armazenamento inadequado, pode prejudicar a eficácia da vacina. $\mathrm{O}$ título viral das vacinas vivas reduz devido à inativação do vírus ao longo do prazo de validade do produto (OIE, 2010; CANAL e VAZ, 2012; NAIR e SCHAT, 2013).

\section{CONSIDERAÇÕES FINAIS}

A intensificação da avicultura agregada a condições e práticas de manejo muitas vezes não são eficazes contra agentes patogênicos. A imunossupressão tem importância significativa na produção comercial avícola, sendo que o Herpes vírus é altamente imunossupressor, sendo assim, existem grandes perdas econômicas, decorrente da exposição de aves a esse agente, levando-a queda no desempenho zootécnico e a vulnerabilidade a infecção secundarias. É por esse motivo que a prevenção e controle é de extrema importância para avicultura.

Partindo do pressuposto, que até o momento, pouca informação existe sobre esse assunto é importante que se faça novos estudos onde as informações geradas serão de suma importância para indústria da avicultura, instituição de pesquisa e universidades gerando assim um avanço do conhecimento e elucidação de processos biológicos.

\section{REFERÊNCIAS}

ABDUL CAREEM, M. F.; HUNTER, B.D.; NAGY,É., et al. S.Development of a real-time PCR assay using SYBR Green chemistry for monitoring Marek's disease virus genome load in feather tips. Journal of virological methods, v.133, p.34-40, 2006.

BAATEN, B. J. G; BUTTER, C.; DAVISON, T. F.Study of host-pathogen interactions to identify, sustainable vaccine strategies to Marek's disease. Veterinary Immunology and Immunopathology, v.100, p. 165-177, 2004.

BAIGENT, S. J.; PETHERBRIDGE, L.J.; HOUWES, K., et al. Absolute quantitation of Marek's disease virys genome copy number in chicken feather and lymphocyte samples using real time PCR. Journal of Virological Methods. V. 123, p. 53-54, 2005. 
BACK, A. Manual de doenças de aves. Cascavel: Editora Coluna Saber, 2004. p. 100-110.

CANAL, C.W.; VAZ, C.S.L. Vacinas víricas. In: Virologia Veterinária. Ed. UFSM, Santa Maria, 2012

CANAL, C. W.; SILVA, E. N. Enfermidades de Marek, Complexo Leucótico Aviário e Reticuloendoteliose. In: BERCHIERI JUNIOR, A.; MACARI, M. Doenças das aves. Campinas: Editora FACTA, 2000. cap. 5, p. 255-265.

CANAL, C. W.; BARBOSA, T. M. C. Enfermidade de Marek, Complexo Leucótico Aviário e Reticuloendoteliose. In: JÚNIOR, A. B.; SILVA, E. N.; FÁBIO, J.; SESTI, L.; ZUANAZE, M. A. F. Doenças das aves. 2a edição. Editora FACTA. Campinas, 2009. p 569-576.

FRANCO, A.C.; ROEHE, P.M.; VARELA, A.P.M.; Herpesviridae. Virologia Veterinária, 2a edição, Editora da UFSM, Santa Maria, p. 503- 570, 2012

GIMENO, I. Doença de Marek. In: REVOLLEDO, L; FERREIRA, A. Patologia Aviária. Barueri, SP: Manole, 2009.

GRIEBELER, J. 2005. Titulação de vacinas contra o sorotipo 3 do vírus da doença de marek por PCR em tempo real. Disponível em: <http://www.lume.ufrgs.br/handle/10183/7077>. Acesso em: 10 Mar. 2018.

HEIDARI, M.;SARSON A. J.; HUEBNER. H., et al.Marek's disease virus- induced immunosuppression: array analysis of chicken immune response gene expression profiling. Viral immunology, v.23, p.309-319, 2010.

ISLAM, A., HARRISON, B., CHEETHAM,B .F., MAHONY, T. J.,et al. Differential amplification and quantitation of Marek's disease viruses using real-time polymerase chain reaction. Journal of Virological Methods, v. 119, p. 103-113, 2004.

ISLAM, A. CHEETHAM, B. F.; MAHONY, T. J.,et al .Absolute quantificaton of Marek's disease virus and herpesvirus of turkeys in chicken lymphocyte, feather tip and dust samples using real-time PCR. Journal of Virological Methods. In Press, 2005

LANDMAN, W. J.; VERSCHUREN, S.B. Titration of Marek's disease cell-associated vaccine virus (CVI 988) of reconstituted vaccine and vaccine ampoules from Dutch hatcheries. Avian Diseases, v.47, p.1458-1465, 2003.

NAIR, A. Absolute quantification of Marek's disease virus and herpesvirus of turkeys in chicken lymphocyte, feather tip and dust samples using real-time PCR. Journal of Virological Methods. In Press, 2005

OSTERRIEDER, N.; KAMIL, J.P.; SCHUMACHER, D.; et al. Marek's disease virus: from miasma to model. Nature, v.4, p.283-294, 2006 
OIE- Office International des Epiooties.Manual of diagnostic tests and vaccines for terrestrial animals.6. ed. Paris, 2010.

SALLE, C. T. P.; MORAES, H. L. S. Prevenção / Manejo profilático/ Monitoria. In: JÚNIOR, A. B.; SILVA, E. N.; FÁBIO, J.; SESTI, L.; ZUANAZE, M. A. F. Doenças das aves. 2a edição. Editora FACTA. Campinas, 2009. p 9-13.

SANTOS, B.M.; MOREIRA, M.A.; DIAS, C.C.A. Manual de Doenças Avícolas. Editora UFV, p.64, 2008.

SESTI, L. Biosseguridade em granjas de frango de corte: conceitos e princípios gerais. In: SIMPÓSIO BRASIL SUL DE AVICULTURA, 5., 2004, Chapecó. Anais. Concódia: Embrapa Suínos e Aves, 2004.p 55-72.

SESTI, L. Biosseguridade em granjas de reprodutores. In: MACARI, M; MENDES, A.A. Manejo de Matrizes de corte, Fundação APINCO de Ciência e Tecnologias Avícolas: Campinas, 2005, Cap.12, p.243-321, 2005.

SILVA, P.L. Doença de Marek. In: ANDREATTI FILHO, R. L. Saúde aviária e doenças. São Paulo: Roca, 2006. cap.17.1, p. 154-159.

SILVA, P.L. 2016. Neoplasia e Imunossupressão: Novos e antigos desafios de uma das principais doenças da avicultura industrial. Disponível em: <http://www.avisite.com.br/clipping/CevaWorld_02_Marek.pdf>.Acessoem: 12 Mar. 2018.

SCHAT, K.A.; NAIR, V. Marek's disease. In: Diseases of Poultry, Twelfth Edition, Saif Y.M. et al., eds. Blackwell Publishing, Ames lowa, USA, p. 452-514, 2008.

SCHAT, K. A.; NAIR, V. Neoplastic Diseases. In: Diseases of Poultry, 13th ed. (SWAYNE, D. E.; GLISSON, J. R.; MCDOUGALD, L. R.; NOLAN, L. K.; SUAREZ, D. L.; NAIR, V. L. eds.), John Wiley \& Sons, Inc., Ames, p.513-673, 2013.

TORRES, A.C.D. Detecção e caracterização molecular do Vírus da Doença de Marek em Minas Gerais. 2017. Disponível em: <http://www.bibliotecadigital.ufmg.br/dspace/bitstream/handle/1843/SMOCAX4PRR/ana_caroline_doyle_torres.pdf?sequence $=1>$. Acesso em: 26 de mai. de 2018.

TULMAN, E .R.; AFONSO , C. L.; ZAOXIA. L., et al.The genome of a very virulent Marek's diseases vírus. Jornal of Virology, v.74, n. 17, p. 7980-7988, sept 2000

VENUGOPAL, K. Marek's: an update on oncogenic mechanisms and control. Research in Veterinary Science. v. 69, p. 17-23, 2000. 
WAKENELL, P.S.; BRYAN, T. SCHAEFFER, J., et al. Effect of in ovo vaccine delivery route on herpesvirus of turkeys/ SB-1 efficacy and viremia. Avian Diseases. V. 46, p.247-280, 2002.

WITTER, R. Vacinas contra a Doença de Marek: Passado, Presente e Futuro. XXI Congresso Mundial de Avicultura, 20-24 de agosto de 2000.

WITTER, R. L.; SHARMA, J. M.; FADLY, A. M. Pathogenicity of variant Marek's diasease virus isolants in vaccinated and unvaccinated chickens Avian Diseases, v. 74, n. 8, p.3605-3612, 2000

WITTER, R.L.; SCHAT, K.A. Maarek's disease. In SAIF, Y.M.; BARNES, H.J.; FADLY, A.M.; GLISSON, J.R.; McDOUGALD, L.R.; SWAYNE, E (ed) Diseases of Poultry, 11th ed. lowa State University Press, Ames, IA, p.407-465, 2003.

YUNYS, R.; JAROSINSKI, K. W.; SCHAT.K.A.Association between rate of viral genome replication and virulence of Marek's disease herpesvirus strains.Virology, v. 328, p. 142-150, 2004. 


\section{CAPÍTULO X}

\section{ERLIQUIOSE MONOCITICA CANINA - ABORDAGEM CLÍNICA E TERAPÊUTICA DA INFECÇÃO}

DDI: 10.51859/amplla.pdi443.1121-10

Amanda Corá dos Santos ${ }^{1}$ Carolina de Alvarenga $\mathrm{Cruz}^{2}$

Andresa de Cássia Martini ${ }^{3}$

Eric Mateus Nascimento de Paula ${ }^{3}$

\footnotetext{
1 Médica Veterinária Autônoma. Egressa do Curso de Medicina Veterinária do Centro Universitário de Mineiros UNIFIMES

${ }^{2}$ Médica Veterinária Autônoma. Doutora em Medicina Veterinária pela Unesp/FCAV.

${ }^{3}$ Docente do Curso de Medicina Veterinária do Centro Universitário de Mineiros - UNIFIMES.
}

\section{RESUMO}

A Erliquiose monocítica canina é conhecida popularmente como "doença do carrapato". É uma hemoparasitose provocada pelo carrapato marrom ou vermelho (Rhipicephalus Sanguineus), infectados por bactérias do gênero Ehrlichia. Sendo encontrado frequentemente em áreas tropicais e sub-tropicais através de sua distribuição geográfica. É uma doença infecto-contagiosa, onde a transmissão se dá através do carrapato contaminado, que leva a bactéria de um cão infectado para outro saudável durante o repasto sanguíneo. A bactéria infecta as células mononucleares que se replica por fissão binária dando início a doença. Após sua infecção, a E. canis leva às fases aguda, subclínica, e a fase crônica da doença. Há grandes riscos de o animal ser levado à óbito durante a fase crônica, devido ao diagnóstico tardio por se tratar de uma doença silenciosa em sua fase assintomática. A erliquiose é uma doença com alta incidência na rotina clínica veterinária, devido a este fator, está revisão tem como objetivo elucidar as particularidades sobre essa enfermidade, dando atenção aos meios de controle e prevenção de seus vetores.

Palavras-chave: Carrapato. Controle. Erlichia canis.

\section{INTRODUÇÃO}

Os cães (Canis familiaris) são um dos mais populares e procurados animais de estimação, sendo considerado como o melhor amigo dos seres humanos. Sua utilização vem crescendo como cães policiais e para tratamentos terapêuticos de pacientes humanos em doenças limitantes como câncer. Nessa última situação proporcionam um 
bem-estar e uma melhora psicológica considerável. São, portanto, animais de grande importância na população, por serem animais sociáveis e com grande capacidade auditiva e olfatória. No Brasil a procura de cães como animais domésticos vem aumento cada vez mais, de maneira significativa, pois atualmente tem sido considerados membros da família, onde vários casais optam por criar um animal de companhia, ao invés de ter um filho. Isso faz com que os proprietários acabem tomando mais cuidado com a saúde de seus pets.

Ter um animal em casa requer tempo, atenção, investimento, exigindo dos proprietários algumas obrigações como idas ao veterinário, banho, vacinas e vermifugação atualizadas, alimentação adequada e de boa qualidade e realizar o controle de ectoparasitas como pulgas e carrapatos por meio de medidas que estão no mercado, como uso de carrapaticidas, coleiras, produtos tópicos (pour-on) e a dedetização do ambiente, sendo proporcionando ao animal um maior bem-estar.

Os carrapatos são de grande importância aos cães, pois sua presença no animal pode causar um grande desconforto como coceira, vermelhidão na pele pela picada e além de serem transmissores de algumas doenças, que variam seus sintomas e tratamento de acordo com seu patógeno. No Brasil as doenças relacionadas aos carrapatos mais conhecidas são: febre maculosa, doença de Lyme, anaplasmose, babesiose, tularemia, e a erliquiose canina.

O foco deste trabalho é levantar dados bibliográficos sobre a erliquiose monocítica canina (EMC), que é uma doença infecciosa, de caráter multissistêmico descrita mundialmente, que acomete animais domésticos, selvagens e humanos, possuindo como agente etiológico, uma bactéria intracelular obrigatória. É uma enfermidade muito importante na clínica médica de pequenos animais, devido sua alta taxa de morbidade e mortalidade sendo responsável pelo comprometimento de diversos cães.

\section{REVISÃO DE LITERATURA}

\subsection{Definição}

Erliquiose Monocítica Canina (EMC) é uma doença infectocontagiosa transmitida pela mordida do carrapato Riphicephalus sanguíneus durante o repasto sanguíneo. 0 
carrapato marrom ou vermelho, se infecta com a bactéria Riquétsia Erhlichia sp, quando se alimenta do sangue de um cão acometido pela doença, onde leva a bactéria para um cão saudável. É descrita como uma das principais doenças infecciosas que acomete cães em várias partes do mundo (PEREZ et al., 1996).

A EMC já recebeu vários nomes, dentre eles estão: Riquétsiose Canina; Pancitopenia Tropical Canina; Tifo Canina; Febre hemorrágica canina; Síndrome Hemorrágica Idiopática; Moléstia do Cão Rastreador (BREITSEHWERDT, 1997; JONES et al., 2000).

\subsection{Histórico}

A Erliquiose é relatada em grande parte das regiões tropicais e subtropicais de todo mundo (ETTINGER \& FELDMAN, 2004). Na Armada Americana, ocorreu uma epizootia da erliquiose canina, durante a guerra do Vietnã, acometendo muitos cães militares, onde recebeu o nome de pancitopenia tropical canina, apresentando sintomas caracterizados por anemia, leucopenia e epistaxes. Sua primeira descrição ocorreu na Argélia, por Donatien e Lesquard em um cão pastor alemão, nomeado de Ehrlichia Canis no ano de 1945, na cidade de Maskovsky (HUXSOLL et at., 1970).

De acordo com Megid (2016 cap.09) acredita-se que R. sanguineus chegou ao Brasil através de colonizadores europeus a partir do século 16, quando exportavam animais domésticos do continente africano.

No Brasil a doença foi relatada pela primeira na cidade de Belo Horizonte (COSTA et al.,1973). Posteriormente, foi descrito que aproximadamente $20 \%$ dos cães atendidos em hospitais e clínicas veterinárias de Estados das regiões Nordeste, Sudeste, Sul e Centro-Oeste foram acometidos pela enfermidade (LABARTHE et al., 2003).

\subsection{Agente Etiológico e Vetor}

Os micro-organismos que estão associados com a EMC incluem: Erlichia canis, E. chaffeensis e Neoricketssia risticii. Um cão pode ser infectado por mais de um agente da erliquia, comumente a outros patógenos que também são transmitidos pelo carrapato (KORDICK et al., 1999).

Para Ettinger e Feldeman (2004. P, 1330) a E. canis é o mais comum destes agentes onde o quadro clínico da doença é mais agravante. 
As bactérias do gênero Ehrlichia são micro-organismos intracelulares obrigatórios para as células mononucleares maduras ou imaturas de mamíferos como os monócitos, macrófagos, linfócitos, os neutrófilos e das células endoteliais. O microorganismo infecta as células de glândulas salivares e do epitélio intestinal nos carrapatos (MEGID et al., 2016). Pertence à ordem Rickttsiales, família Anaplasmataceae, do gênero Ehrlichia (DUMLER et al., 2001).

A transmissão da Ehrlichia canis ocorre com a participação de um vetor, o carrapato Rhipicephalus Sanguineus (COUTO, 1998; ALVES et al., 1994). O microorganismo não é transmitido via transovariana no carrapato, sendo assim, os carrapatos que não são expostos devem parasitar um cão acometido pela doença em sua fase aguda, para se tornar infectante e transmitir a doença (NELSON \& COUTO, 1992).

A infecção canina provavelmente ocorre quando as secreções salivares do carrapato contaminam o ponto de fixação durante a ingestão de sangue em um repasto. A infecção pela E. Canis também pode ser introduzida em cães suscetíveis por meio de transfusão sanguínea (ETTINGER \& FELDEMAN, 2004).

A E. canis invade os leucócitos mononucleares, onde se multiplica por divisão binária. O micro-organismo se instala no citoplasma celular e se reproduz no interior de fagossomos na forma de corpúsculos iniciais que se unem para formação da mórula (ALMOSNY \& MASSARD, 2002). Acredita-se que os carrapatos adultos são capazes de transmitir a E. canis por pelo menos 155 dias após a separação do hospedeiro (ETTINGER \& FELDMAN, 2004).

\subsection{Epidemiologia}

Segundo Ettinger e Feldman (2004. P, 424) a distribuição geográfica da EMC é relacionada à distribuição do carrapato vetor, Rhipicephalus Sanguineus, o carrapato marrom do cão. Embora essa enfermidade seja mais evidente no Sudeste e Sudoeste dos Estados Unidos, a doença foi diagnosticada em quase todos os estados. Devido a ocorrência da infecção em suas fases subclínica e crônica, um cão pode se deslocar de uma região onde a prevalência da doença é grande, para uma região onde a doença não é endêmica e desenvolver as manifestações clínicas anos após a infecção inicial.

No Brasil, a frequência de carrapatos infectados tem variado de 2,5 a 6\%. Diante da ausência de transmissão transovariana e do prolongado estado do portador de E. 
canis, o cão é considerado o principal reservatório da doença. Ele atua como fonte de infecção para os carrapatos após a instalação da fase aguda da infecção, sendo rara a transmissão do agente para carrapatos por cães na fase crônica (MEGID et al., 2016). A prevalência da EMC é maior na região Nordeste (43\%) e com casos menos frequentes no Sul do país $(1,70 \%)$. Sua incidência é mais evidente em meses mais quentes onde o vetor se desenvolve (LABARTHE et al., 2003).

O risco de infecção pela E. canis é mais evidente em cães que vivem em casas, pois tem acesso há quintais onde pode haver presença de carrapatos do que os que vivem em apartamentos (COSTA JÚNIOR et al., 2007). Os hospedeiros vertebrados mais importantes e comuns da EMC são membros da família Canídea (cães, coiotes, raposa e chacal) (PEREZ et al., 1996).

\subsection{Patogenia}

A infecção do carrapato pela E. canis ocorre quando os carrapatos se alimentam nos estágios larval ou ninfal em cães durante a fase aguda da infecção (LEWIS et al., 1977). Os carrapatos inoculam a secreção salivar infectada com a bactéria no interior do sítio de alimentação no hospedeiro (DAGNONE et al., 2001). Durante o repasto sanguíneo, componentes salivares do carrapato atuam na resposta imune local, diminuindo a resposta do tipo Th1. Essa supressão favorece a resposta do tipo Th2, o que leva à instalação da infecção. A erliquia invade, então, as células mononucleares no formato de corpúsculo elementares, inibindo a fusão do fagossomo e lisossomo, a qual age como mecanismo de escape da resposta imune do hospedeiro (MEGID et al., 2016).

A E. canis se multiplica em macrófagos do sistema mononuclear fagocitário por fusão binária disseminando por todo o corpo do animal (GREENE, 2006). A infecção pela E. canis pode ser classificada em três fases: aguda, subclínica e crônica (TILLEY, SMITH, 2003). O carrapato deve permanecer fixado por pelo menos, 8 horas no cão para efetivar a transmissão do agente. Vale salientar que a temperatura do vetor deve aumentar para a reativação de E. canis, a fim de que a bactéria se multiplique a quantidades suficientes para desencadear a infecção (MEGID et al., 2016).

Depois do período de incubação, o cão infectado entra na fase aguda da erliquiose, que dura de duas a quatro semanas. Durante este período, o microorganismo multiplica-se dentro das células mononucleares do fígado, baço e linfonodos. 
Isso leva à linfadenomegalia e à hiperplasia linforreticular do fígado e baço. As células infectadas são transportadas através da corrente sanguínea para outros órgãos do corpo, especialmente pulmões, rins e meninges, e aderem-se ao endotélio vascular, induzindo vasculite e infecção tecidual subendotelial (ETTINGER \& FELDMAN, 2004).

A fase subclínica ocorre de seis a nove semanas após a inoculação (ETTINGER \& FELDAMAN, 2004), que é a fase assintomática da doença sem alterações clínicas, porém a riquétsia permanece no organismo persistindo por até anos (WARNER et al., 1996). Durante a fase subclínica não são observados sinais clínicos evidente e, por vezes, em razão da inespecificidade ou da baixa gravidade, os sinais são imperceptíveis aos proprietários, muitos cães começam a emagrecer, surgindo a fase crônica da infecção (MEGID et al., 2016).

A fase crônica da erliquiose pode ocorrer meses ou anos após a infecção. A doença pode apresentar moderada, com algumas características clínicas da fase aguda, ou até mais graves, podendo levar o animal a óbito. Durante esta fase, os animais encontram-se caquéticos, apáticos e suscetíveis às infecções secundárias, em virtude do comprometimento imunológico (MEGID et al., 2016).

\subsection{Sinais Clínicos}

Após o período de incubação que vai de oito a vinte dias, a E. canis se multiplica em linfócitos e monócitos circulantes, linfonodos e vísceras (fígado e baço) induzindo a linfoadenomegalia (BREITSCHWERDT, 2001), nesta fase os sinais são inespecíficos, onde incluem febre, secreções oculonasal purulenta ou serosa, anorexia, perda de peso, dispneia e ixodidiose frequentemente evidenciada. A febre pode ocorrer em ambas as fases clínicas da infecção, porém é mais comum em cães com erliquiose aguda (NELSON \& COUTO, 1992).

A Fase subclínica é caracterizada pela persistência variável de trombocitopenia, leucopenia e anemia (ETTINGER \& FELDMAN, 2004). Animais imunocompetentes, em geral, respondem à infecção ou se tornam portadores assintomáticos do agente. 0 período assintomático é conhecido como a fase subclínica da doença. $\mathrm{Na}$ fase assintomática, o cão tem relevante participação na epidemiologia da erliquiose, pois o agente pode desencadear inúmeros processos de bacteremia, facilitando a infecção de novas populações de carrapatos R. sanguineus (MEGID et al., 2016). 
Na fase crônica os sinais clínicos são ausentes ou discretos em alguns cães (BREITSCHWERDT, 2001; WARNER et al., 1996-). Por exemplo, não é raro em áreas endêmicas detectar alterações hematológicas decorrentes da infecção crônica pela E. Canis em adulticida contra dirofilárias (ETTINGER \& FELDMAN, 2004). Apesar de alguns cães imunocompetentes conseguirem eliminar o micro-organismo durante a fase subclínica, às vezes a bactéria persista de forma intracelular, resultando na fase crônica da infecção, sua forma mais severa (NELSON; COUTO, 1992; QUINN et al., 2005). Os achados clínicos nesta fase, incluem: depressão; perda de peso; palidez das membranas mucosas; dor abdominal; evidências hemorrágicas; linfoadenopatia; esplenomegalia; dispneia; edema de córnea; dor meníngea e paresia; hepatomegalia; rigidez e edema, além de dores em articulações (NELSON \& COUTO, 1992).

\subsection{Achados Anatomopatológicos}

São observados em necropsias de animais que vieram a óbito devido a doença, hemorragias petéquiais, dermatites, edemações, áreas roxas na pele, hemorragia em articulações, esplenomegalia e aumento das tonsilas. Também pode ocorrer edema pulmonar, ascite, hidrotórax e erosões bucais (TILLEY \& SMITH, 2003).

\subsection{Diagnóstico}

As diferentes fases e múltiplas manifestações clínicas causadas pelo microorganismo, o diagnóstico da erliquiose é um desafio para o Médico Veterinário. A doença deve ser suspeitada quando: o histórico, à anamnese, indicar infestação por carrapatos ou viagem para locais onde a doença ocorra de modo enzoótico; os sinais clínicos (principalmente hemorrágicos) presentes forem sugestivos de E. canis, as alterações hematológicas e bioquímicas forem compatíveis com a doença (MEGID et al., 2016).

As alterações hematológicas e bioquímicas vão variar de acordo com a fase em que se encontra a doença (STILES et al.,2008) associam-se a processos inflamatórios e imunomediados, desencadeado por E. canis. A trombocitopenia é o achado hematológico mais comum em cães infectados (MEGID et al.; 2016), vem acompanhada por anemia branda e a redução de leucócitos, se comparados com valores em um animal saudável (HARRUS \& WARNER, 2011). 
Nas alterações bioquímicas são comumente encontradas hipoalbuminemia, hiperglobulinemia, hipergamaglobulinemia (WOODY \& HOSKINS, 1991), aumento da alanima amino transferase e da fosfatase alcalina que é observado durante a fase aguda, onde ocorre um aumento de ambos. Também é observado aumento das concentrações de proteína $C$ reativa entre 4 e 16 dias pós- infecção, com picos de concentração entre 15 e 42 dias após a inoculação de E. canis (MEGID et al., 2016).

A EMC pode ser detectada através de amostras de sangue periférico coradas pelo método Gemsa ou Wright, onde são evidenciadas inclusões citoplasmáticas denominadas mórula (ALVES et al., 1994). Existem também alguns kits sorológicos utilizados na detecção da EMC, como por exemplo, o kit Immunocomb baseado na técnica de "DOT BLOT - ELISA", que determina anticorpos na classe IgG específicos para agente infectante (CASTRO, 1997; MACHADO, 2004).

Os testes sorológicos são considerados confiáveis e eficazes para o diagnóstico dessa enfermidade. A reação de imunofluorescência indireta (RIFI) serve para detectar anticorpos séricos dando soropositividade entre 7 e 21 dias após infecção, porém possui como desvantagem as reações inespecíficas causadas por antígenos comuns a outros agentes do mesmo grupo de erlíquias. O teste de ELISA é considerado um teste específico e sensível assim como o IFI, porém pode ser feito de forma mais rápida possui baixo custo sendo bastante utilizado. O ELISA tem uma desvantagem que é a ocorrência frequente de falso-positivo por detectar anticorpos muita das vezes em animais que estão ou nos que já estiveram em contato com antígeno (DONIZETE, 2016).

Reação em Cadeia da Polimerase (PCR) permite identificar a E. canis em pequenas quantidades mesmo antes de visualizar as mórulas, e identifica sequências genômicas específicas da erlíquia através de tecidos e sangue de células mononucleares de rins, pulmões, baço, linfonodos e cérebro, por exemplo; é uma técnica de alta especificidade e sensibilidade, sendo bastante eficaz. Porém tem como desvantagem seu alto custo. Recomenda-se associar PCR e RIFI para diagnóstico definitivo (MEGID et.al., 2016; REIS, 2017).

\subsection{Diagnóstico Diferencial}

Devido a diversidade de sinais clínicos da erliquiose canina nas fases aguda e crônica, várias outras doenças apresentam sintomatologia similares. São elas: 
babesiose, leptospirose, anemia hemolítica autoimune e neoplasias (mieloma, linfoma e leucemia) devem ser consideradas no diagnóstico diferencial (MEGID et al., 2016).

\subsection{Tratamento}

A doxiciclina é o tratamento de eleição para a EMC. Esse fármaco, derivado da tetraciclina, é indicado na fase aguda, em doses de $10 \mathrm{mg} / \mathrm{kg}$ a cada $24 \mathrm{~h}$, por via oral, durante 21 a 28 dias. A vantagem da doxiciclina (em relação às demais tetraciclinas) é a excreção basicamente intestinal, o que reduz a nefrotoxidade, especialmente em

animais com lesão renal decorrente da infecção por E. canis. Em virtude das propriedades lipofílicas, é também capaz de atravessar a membrana celular, em altas concentrações intracelulares, e alcançar, consequentemente, o patógeno localizado no citoplasma (MEGID et al., 2016).

Outros antibióticos como o cloranfenicol (15 a $20 \mathrm{mg} / \mathrm{kg}$ TID durante 15 dias) pode também ser administrado, porém, há um grau de toxidade na medula óssea, não sendo indicado em cães com anemia ou pancitopenia (GAL, 2007).

O dipropionato de imidocarb tenha conquistado a aceitação clínica em determinadas regiões endêmicas para tratar casos de erliquiose graves, crônicos ou supostamente refratários, foi demonstrada uma falta de eficácia no tratamento de alguns cães com essa doença. A melhora clínica pode ser observada com penicilina ou sulfonamidas, mas a resposta é variável e a infecção normalmente persiste (ETTINGER \& FELDMAN, 2004).

Em alguns casos crônicos, deve realizar o tratamento de suporte. Quando houver a desidratação, fornece a fluidoterapia, e em casos de hemorragia optar pela transfusão sanguínea. Quando há um grau de trombocitopenia, a terapia a base de glicocorticoides e antibióticos pode ser utilizada, assim como nos casos de infecções bacterianas secundárias (PEREZ at al., 1996).

\subsection{Prognóstico}

O prognóstico é bom para cães com erliquiose aguda e é de variável para reservado para aqueles animais com erliquiose crônica. Nos casos agudos, febre, petéquias, vômitos, diarreias, epistaxe e trombocitopenia frequentemente se resolvem dentro de alguns dias após o início da terapia (NELSON \& COUTO, 1992). Há uma boa melhora clínica que ocorre dentro do período de 24 a 48 horas após o início da 
doxiciclina ou tetraciclina em cães na fase aguda ou crônica moderada da doença (ETTINGER \& FELDMAN, 2004).

Quando não houver melhora nos parâmetros clínicos e hematológicos dentro de 2 semanas, o cão deverá ser reavaliado. Em alguns casos, há a redução dos títulos de anticorpos e o animal torna-se soronegativo. Em muitas situações, entretanto, os títulos de anticorpos podem permanecer elevados meses até anos. Atualmente, a PCR é a melhor opção para acompanhar a evolução do tratamento (MEGID et al., 2016).

\subsection{Medidas de Controle e Prevenção}

A profilaxia da erliquiose é fundamentada especialmente no controle do carrapato R. sanguineus. É imprescindível que a terapia carrapaticida atue tanto no hospedeiro como no ambiente (NELSON \& COUTO, 1992).

Para uso direto nos animais, existem no mercado comprimidos que agem diretamente na corrente sanguínea do animal, ampolas pour-on, sprays e coleiras. No ambiente são utilizados em geral produtos à base de amitraz ou cipermetrinas diluídos e aplicados conforme a recomendação do fabricante. Para que haja melhor controle do carrapato, deve-se conhecer o seu ciclo de vida, devido a capacidade de a fêmea colocar milhares de ovos no ambiente que vão eclodir por vários dias (VIGNARD-ROSEZ et al., 2017).

Portanto, é importante que o controle seja feito não apenas uma vez e sim, continuamente, principalmente em regiões onde a proliferação de carrapatos são abundantes (COUTO 1998; MEGID et al.; 2016).

\section{CONSIDERAÇÕES FINAIS}

A EMC é uma das doenças mais importantes na clínica de pequenos animais, por se tratar de uma doença infectocontagiosa grave. É transmitida pela picada do carrapato (Riphicephalus sanguineus), encontrado muito facilmente em diversas épocas do ano, onde o maior número de casos da doença ocorre nos meses mais quentes.

Ao picar um cão doente da erliquiose, o carrapato ingere a bactéria Erhlichia canis, que irá se proliferar nas glândulas salivares e em seu intestino. Quando entra em contato com um animal sadio, este carrapato injeta através da saliva a E. canis na corrente sanguínea do animal. As células do sistema imunológico do animal tenta 
combater o agente, que irá se multiplicar e reproduzir dentro de suas células de defesa e espalhar para outros órgãos do corpo, afetando principalmente o baço, fígado e linfonodos.

No diagnóstico da erliquiose, primeiramente o Veterinário deverá verificar se o animal teve contato recente com carrapatos através da anamnese e solicitar exames laboratoriais. São utilizados a imunofluorescência indireta, que detecta anticorpos antiErhlichia no soro de animais suspeitos e é realizado hemograma onde há a possibilidade de encontrar a bactéria no raspado sanguíneo.

O tratamento consiste em antibioticoterapia para combater a E.canis. O antibiótico de eleição é a doxiciclina, aliado a um protetor hepático. Terapia de suporte para a anemia, vitaminas do complexo $B$ e em casos mais graves é realizado transfusões sanguíneas. É necessário que se tenha um maior controle de seu vetor para evitar a infestação do Riphicephalus sanguineus, pois o aumento significativo de animais com erliquiose na rotina clínica veterinária cresce a cada dia. Deve ser feito um controle no animal e também no ambiente onde ele vive.

Hoje no mercado pet há vários produtos para a prevenção da infestação por carrapatos, tais como: comprimidos que age diretamente na corrente sanguínea do cão; pour-on que é absorvido pelas glândulas sebáceas e coleiras. Para o ambiente é importante sempre pulverizar o local, principalmente em frestas de muro, pisos, canto de paredes, onde os carrapatos costumam se alojar.

Conclui-se, portanto, que há uma necessidade de educação preventiva nos grandes centros urbanos para o controle desta doença. O Médico Veterinário tem um papel fundamental para a conscientização da população sobre os cuidados que se deve tomar para evitar a infestação de Riphicephalus sanguineus, principal vetor da erliquiose.

\section{REFERÊNCIAS}

ALMOSNY, N. R. P.; MASSARD, C. L. Erliquiose em pequenos animais domésticos e como Zoonose. Rio de Janeiro. L. F. Livros de Veterinária Ltda. p,174. 2002. 
ALVES, R. N. F.; ATHAYDE, A. C. R.; SILVA, W. W.; LIMA, S.M. Ocorrência de erlichiose canina no semi-árido paraibano. Ciência animal, v. 4, n.2, P. 22-25, 1994. BREITSEHWERDT, E.B. As riquetisioses. In: ETTINGER, S.J; FELDMAN, E.C. Tratado de Medicina Interna Veterinária - Moléstias do cão e do gato. São Paulo. $4^{\circ}$ edição. Volume 1. Manole, cap 67. p, 543-553.1997.

CASTRO, M.B. Avaliação das alterações hematológicas, imunológicas e anatomopatológicas na infecção aguda experimental de cães, por Ehrlichia canis. Dissertação (Mestrado em Patologia Veterinária) - Universidade Estadual Paulista, Jaboticabal, 1997.

CASTRO, M.B.; MACHADO, R.Z.; AQUINO, L.P.C.T.; ALESSI, A.C.; COSTA, M.T. Experimental acute canine monocytic ehrlichiosis: clinicopathological and immunopathological findings. Veterinary Parasitology. Amsterdam, 2004.

COUTO, C. G. Doenças rickettsiais. In: BICHARD, S. J.: SHERDING, R. G. Manual Saunders: clínica de pequenos animais. Rio de Janeiro: Roca. p,139-142. 1998.

COSTA, J.O. et al. Ehrlichia canis infection in dog in Belo Horizonte, Brazil. Arq. Esc. Vet. UFMG, Cap 25. p,199-200, 1973.

COSTA JR, L.M.; REMBECK, K.; RIBEIRO, M.F.; BEELITZ, P.; PFISTER, K.; PASSOS, L.M. Soroprevalence and risk indicators for canine ehrlichioses in three rural areas of Brazil. Vet j, Cap 174. p, 673-676, 2007.

DAGNONE, A. SILVIA. Erliquiose nos animais e no homem. Semina: Ciências Agrárias. p, 191 - 201. 2001.

DONIZETE, J.C. Ocorrência erliquiose em cães atendidos em clínica Médico Veterinária da cidade de Arcos-MG. 2016. p. 34. Trabalho de conclusão de curso (Graduação em Medicina Veterinária) - Centro Universitário de Formiga, Medicina Veterinária, Formiga-MG.

DUMLER, J. S.; BARBET, A. F.; BEKKER, C. P. J.; DASCH, G. A.; PALMER, G. H.; RAY, S. C.; RIKIHISA, Y.; RURANGIRWA, F. R. Reorganization of genera in the families Rickettsiaceae and Anaplasmataceae in the order Rickettsiales: unification of some species of Ehrlichia with Anaplasma, Cowdria with Ehrlichia and Ehrlichia with Neorickettsia, descriptions of six new species combinations and designation of Ehrlichia equi and HGE agent as subjective synonyms of Ehrlichia phagocytophila. International Journal of Systematic and Evolutionary Microbiology. Cap 51. p, 2145- 2165, 2001.

ETTINGER, S.J.; FELDMAN. Tratado de Medicina Interna Veterinária; Editora Manole, $5^{\circ}$ Edição, volume 1 e 2. São Paulo, 2004.

GAL, A. et al. Coinfection with multiple tick-borne and intestinal parasites in a 6- weekold dog. Canadian Veterinary Journal, Ottawa, Cap 48, p, 619-22, 2007. 
GREENE, C.E. Infectious Diseases of the dog and cat. $3^{\circ}$ Ed., St. Louis, Elsevier, 1387 p., 2006.

HARRUS, S.; WANER, T. Diagnosis of canine monocytotropic ehrlichiosis (Ehrlichia canis): an overview. The Veterinary Journal, London, cap 187, p, 292-296, 2011.

HUXSOLL, DL.; HILDEBRANDT, P.K. NIMS, R.M; WALKER, J.S. Tropical canine pancytopenia. Journal of American Veterinary Medical Association, Cap 157, p,1627- 1632, 1970.

KEEFE, T. J.; HOLLAND, C. J.; SALYER, P. E.; RISTIC, M. Distribution of Ehrlichia canis among military working dogs in the world and selected civilian dogs in the United States. Journal of the American Veterinary Medical Association, Cap 181, p. 236238, 1982.

KORDICK, S.K. et al. Coinfection with Multiple Tick-Borne pathogens a walker hound kennel in North Carolina. Journal of Clinical Microbiology, Cap 37, p 2631-2638, 1999.

JONES, T.C; HUNT, R.D.; KING, N.W. Patologia Veterinária. $6^{\circ}$ edição. São Paulo: Manole, p 401-402. 2000.

LABARTHE, N.; CAMPOS PEREIRA, M.; BALBARINI, O.; MCKEE, W.; COIMBRA, C. A.; HOSKINS, J. Serologic prevalence of Dirofilaria immintis, Ehrlichia canis and Borrelia burgdorferi infection in Brazil. Veterinary Therapeutics, Cap 4, p 67-75, 2003. LABRUNA, M. B.; PEREIRA, M. C. Carrapatos em cães no Brasil. Clínica Veterinária, Cap 30, p 24-32, 2001.

LEWIS, G.E. et al. The Brown Dog Tick Rhipice-phalus sanguineus and the Dog as Experimental Hosts of Ehrlichia canis. American Journal of Veterinary Research, Cap 38, p, 1953-1955, 1977.

LITTLE, S.E. Ehrlichiosis and Anaplasmosis in dogs and cats. Vet Clin Small Anim, Cap 40, p,1121-1140, 2010. J. CVSM, 2010.

MACHADO, R.Z. Erliquiose canina. Revista Brasileira de Parasitologia. Vet., Cap 13, p, 5357,2004 .

MEGID, J. Doenças infecciosas em animais de produção e companhia/ Jane Megid, Márcio Garcia Ribeiro, Antonio Carlos Paes. $1^{\circ}$ Edição. Editora Roca: Rio de Janeiro, 2016.

NELSON, R. W.; COUTO, G. Fundamentos de Medicina Interna de Pequenos Animais. $1^{\circ}$ Edição. Editora Guanabara Koogan: Rio de Janeiro, p 737, 1992. 
PEREZ, M.; RIKIHISA., Y.; WEN, B. Ehrlichia canis-like agente isolated from a man in Venezuela: antigenic and genetic characterization. Journal Clinical Microbiology, Washington, Cap 34, p, 2133 - 2139, 1996.

REIS, C. M. M; PINTO, L. C. Erliquiose canina: Relato de caso. Revista científica de Medicina Veterinária. Rio Preto, volume 1. p, 1-11, maio, 2017.

QUINN, P. J.; MARKEY, B. K.; CARTER, M. E.; DONNELLY, W. J. C.; LEONARD, F. C. Microbiologia veterinária e doenças infecciosas. Porto Alegre: Artmed, 2005. STILES, J. (2000). Canine rickettsial infectious. Vet. Clin. North Am. Small Anim. Pract., Philadelphia, v. 30, p. 1135-1150.

TILLEY, L., SMITH., FRANCIS, K. Consulta Veterinária em 5 minutos: espécie canina e felina. $2^{\circ}$ edição. Editora Manole, 2003.

VIGNARD-ROSEZ, K. S. F. V.; ALVES, F. A. R.; BLEICH, I. M.; WOODY, B. J. Erliquiose canina. Disponível no site www.cepav.com.br. Acessado em 18 de Novembro de 2017.

WANER, T. et al. Detection of Ehrlichial antigen in plasma of beagle dogs with experimental acute Ehrlichia canis infection. Veterinary Parasitology, cap 63, p, 331- 335, 1996.

WOODY, B. J.; HOSKINS, J. D. Ehrlichial diseases of dogs. Veterinary Clinics of North America: Small Animal Practice, Cap 21, p, 75-99, 1991. 


\section{CAPÍTULO XI}

\section{LEISHMANIOSE VISCERAL CANINA E SEUS ASPECTOS EM SAÚDE PÚBLICA}

DDI: 10.51859/amplla.pdi443.1121-11

Yanka Rodrigues Alves ${ }^{1}$ Raphaella Barbosa Meirelles-Bartoli ${ }^{2}$

Eric Mateus Nascimento de Paula ${ }^{3}$

${ }^{1}$ Médica Veterinária Autônoma. Egressa do Curso de Medicina Veterinária do Centro Universitário de Mineiros UNIFIMES

2 Docente do Curso de Medicina Veterinária da Universidade Federal de Jataí - UFJ.

${ }^{3}$ Docente do Curso de Medicina Veterinária do Centro Universitário de Mineiros - UNIFIMES.

\section{INTRODUÇÃO}

As leishmanioses estão entre as seis principais zoonoses com maior ocorrência no mundo. São enfermidades transmitidas durantes o repasto sanguíneo da fêmea infectada por um tipo de flebótomo, repassando a forma promastigota desse protozoário, a Leishmania, acomete em geral os animais e os seres humanos (BRANDÃO; MOTANHA, 2011).

A infecção destaca-se por cursar em duas principais formas, sendo essas: a Leishmaniose Tegumentar Americana (LTA), destacada por acometer principalmente os seres humanos; e a Leishmaniose Visceral (LV), caracterizada por infectar os seres humanos e os animais, assim entre os animais o cão é o principal reservatório no meio urbano. Contudo, no meio silvestre, a raposa, lobo e os marsupiais também são possíveis reservatórios (SCHIMMING; SILVA, 2012).

A LV apresenta distribuição por todo o planeta, com alto índice de mortalidade, atingindo aproximadamente 59.000 mortes por ano. Há relatos em todos os continentes. Dentre os países de maior ocorrência destacam se Índia, Sudão, Bangladesh, Nepal e o Brasil, e, que juntos alcançam $90 \%$ dos casos ocorridos (ALVARENGA et al., 2010). No Brasil, todas as regiões têm ocorrência da doença, com um índice maior nas regiões Nordeste, Sudeste, Norte e Centro-oeste. Desta forma, 
torna-se uma das enfermidades de maior preocupação das autoridades de saúde (BRASIL, 2014).

Assim, a doença quando acomete os cães é denominada de Leishmaniose Visceral Canina (LVC), caracterizada por ser de uma doença sistêmica que acomete principalmente medula óssea, fígado e baço. Os principais sintomas são emagrecimento, perda de pelo, ornicogrifose e feridas por todo o corpo do animal, podendo alcançar todos os órgãos, levando o animal a morte (GONTIJO; MELO, 2004). Cerca de 90\% dos cães estão predispostos a se infectar com a doença por todo o mundo (ALVARENGA et al.2010).

O agente etiológico da LV e a LVC, no Brasil, é a Leishmania chagasi, o vetor de transmissão é do gênero Lutzomyia, em especial Lutzomyia longipalpis, Lutzomyia cruzi e Migonemyia migonei. O vetor é um tipo de flebótomo, vulgarmente conhecido como mosquito palha, tatuquira ou birigui. Sua reprodução se dá em ambientes onde há a presença de matéria orgânica em decomposição e solo úmido (PITA-PEREIRA et al. 2008).

\section{REVISÃO DE LITERATURA}

\subsection{Definição}

A LV é uma doença endêmica, de caráter zoonótico e crônica. Que acomete seres humanos já a LVC é caracterizada acometer animais domésticos e animais selvagens; sendo que o animal de maior reservatório no meio urbano é o cão, e no ambiente silvestre é a raposa. Essa enfermidade também é conhecida como calazar, febre dundum ou esplenomegalia tropical (SILVA, 2019). Tem etiologia parasitária, transmitida por meio do repasso sanguíneo da fêmea do flebótomo infectada por Leishmania. Caracterizada por ser uma doença que acomete principalmente baço, medula e óssea fígado podendo ocasionar falência múltipla dos órgãos em casos graves (ALVES, 2009).

A LV já foi descrita em 88 países distribuídos em quatro continentes. É uma enfermidade considerada grave devido sua ampla distribuição e alto índice de letalidade. Afeta cerca de 3 milhões de pessoas a cada ano, principalmente em áreas tropicais da América do Sul, América central, Ásia e Oriente Médio (YOUSSEF et al. 2019). 


\subsection{Histórico}

O primeiro caso humano de leishmaniose descoberto no mundo foi na Grécia, em 1935, quando se denominou a enfermidade com um nome de origem indiana "Kalaazar", cujo significado é doença fatal ou doença negra. William Leishman e Donovan foram os pesquisadores que descobriram, no século XX, que a doença era causada por um protozoário. Assim algum tempo depois em homenagem a eles, Ross denominou o parasita de Leishmania donovani. Já em animais, o primeiro caso registrado foi na Tunísia, após uma pesquisa e identificação de formas amastigotas no exame de um cão (PAULA, 2016).

O primeiro caso de LVC no Brasil, foi relatado em 1938, após encontrarem na pele de um cão a forma amastigota. A partir disso e ao longo dos anos, o cão passou a ser classificado como o reservatório fundamental da doença no ambiente urbano (SOUZA, 2015).

\subsection{Agente etiológico e vetores}

A LV e a LVC são causadas por protozoários tripanossomatídeos, tendo Leishmania infantum chagasi com a principal espécie. Esses parasitos são disseminados por vetores. As leishmanias são microrganismos intracelulares e parasitam, principalmente, macrófagos. Sua forma flagelada denominada de promastigota possui um tamanho de 2,5 a 5,0 $\mathrm{m}$ e 1,5 a 2,0 de largura, encontrada no tubo digestivo do vetor. Já sua outra na forma aflagelada denominada de amastigota encontra se localizada nos tecidos dos vertebrados (BRASIL, 2017).

Existem no mundo duas espécies de Leishmania. A L. donovani é responsável por acometer somente os humanos e está presente em países da Ásia, Europa e África. E a L. infantum chagasi responsáveis por acometer tanto os cães quanto os seres humanos, sendo encontradas nas Américas (SILVA, 2007).

No Brasil, os agentes etiológicos são disseminados pelos insetos hematófagos Lutzomyia longipalpis e Lutzomyia cruzi, sendo que o Lutzomyia cruzi foi descoberto apenas no Mato Grosso (QUEIROZ et al., 2012). Além disso Migonemyia migonei está sendo considerado possível vetor, encontrado no Estado de Pernambuco (PITA- PEREIRA et al. 2008). 
De acordo com Paula (2016), o vetor é pertencente da família Psychodidae, da subfamília Phlebotominae, do gênero Lutzomyia. Esses insetos também são conhecidos como mosquito palha, birigui e tatuquira. São encontrados em áreas quentes, úmidas e tropicais. Normalmente, seu habitat de escolha é em florestas, mas devido os resultados ocasionados por inúmeras mudanças ambientais feitas pela ação dos seres humanos, os flebótomos têm sido observados frequentemente em áreas urbanas, em locais onde vivem animais domésticos. Possuem hábitos crepusculares e noturnos (ESCOBAR et al. 2018).

São pequenos insetos de 1.0 a 3,0 mm de comprimento, de cor amarela, antenas longas, asas grandes, pernas longas com pequenas cerdas, com um corpo piloso. Tem um costume de voar em saltos pequenos e posar com a asas abertas, tornando fácil seu reconhecimento (Brasil, 2014). O macho tem aparelho bucal rudimentar, não sendo capaz de se alimentar de vertebrados; considerado, portanto, fitófago. Já as fêmeas realizam hematofagia, pois para que ocorra a maturação dos ovos o sangue é importante (BASTOS, 2012).

O ciclo biológico desses parasitos se dá em ambientes terrestres, dividido em quatro estágios de desenvolvimento, sendo: ovo, larva, pupa e adultos. Após a cópula, as fêmeas depositam seus ovos em locais úmidos e com uma grande concentração de matéria orgânica em decomposição, para que seja garantida a alimentação das larvas, que eclodem em média de 7 a 10 dias pós postura. Em seguida as larvas se desenvolvem entre 20 a 30 dias, mas se o ambiente não estiver favorável o ciclo de crescimento será interrompido parcialmente, fenômeno conhecido como dipausa. A larva permanece com seu metabolismo reduzido, como uma forma de resistência, até o meio ambiente se tornar favorável para o seu desenvolvimento. Em seguida, as larvas se transformam em pupa, que possuem respiração aérea e não se alimentam. $O$ processo de desenvolvimento do ovo até sua fase adulta, duram em média de 30 a 40 dias, isso dependera da temperatura do ambiente (MAIA, 2013)

A infecção do inseto ocorre após a fêmea do flebótomo ingerir o sangue de mamíferos infectado contendo a forma amastigota. Após isso, ocorre divisão binária do protozoário, se transformando em promastigota, migrando para a faringe e o esôfago do vetor. $\mathrm{O}$ ciclo deste parasito se completa em torno de 72 horas. Em seguida a fêmea 
infectada realiza outro repasto sanguíneo, e por meio de sua saliva transmite a leishmania para um novo hospedeiro (BRASIL, 2014).

\subsection{Epidemiologia}

A LV está distribuída por todo o mundo, sendo endêmica em 54 países. Brasil, Sudão, Nepal, Bangladesh e Índia são os países com maior ocorrência da doença, contabilizando aproximadamente $90 \%$ dos casos. Devido à escassez de informação e o alto índice de pessoas precárias e com baixa renda, uma grande parte da população não possui acesso ao tratamento e diagnostico, aumentando cada vez mais o índice de letalidade (GONTIJO; MELO, 2004). Há a estimativa de que um cão esteja infectado na Europa é de aproximadamente 2,5 milhões. Nas Américas, a ocorrência da LVC já ultrapassa a casa dos milhões, com destaque para o Brasil e a Venezuela (MARCONDES; ROSSI, 2013).

No Brasil a enfermidade ocorre em todas as regiões com maior incidência no Nordeste, especialmente no Maranhão, Ceará e Bahia. Na sequência, vem a Região Norte (com o Estado de Roraima), a Região Sudeste com maiores casuísticas em Minas Gerais, São Paulo e Rio de Janeiro, e por fim, a região Centro-oeste (YOUSSEF, 2019).

Na região Centro-oeste Goiás é o terceiro estado com maior número de casos de LVC, com 2.117 cães notificados até o ano de 2017. No ano de 2017, em questão, ocorreram cerca de 242 casos. 57 municípios goianos possuem casos da doença, sendo o de maior ocorrência: Planaltina, Niquelândia, Goiás, Ipameri, Campos Belos, Valparaíso de Goiás, Campos Verdes, Cocalzinho de Goiás, Colinas do Sul, Cavalcante, São Simão, Aparecida de Goiânia, Nova Iguaçu de Goiás, Aragarças, Anápolis, Pirenópolis, Teresina de Goiás, Porangatu Luziânia, Uruaçu Goiânia e Caldas Novas (BRASIL, 2017).

A LVC possuía um caráter rural, mas com antropização dos ambientes hoje já existem focos em áreas urbanas. Na área urbana o a principal fonte de infecção é o cão classificado como mais prevalentes que no homem (BARATA et al 2005). Já no meio silvestre, destaca se a raposa (Dusicyon vetulus e Cerdocyon thous), seguida dos roedores, edentados, primatas e marsupiais. Além do cão ser o principal reservatório, ainda há caninos que não são identificados por serem assintomáticos, se tornando uma fonte de infecção de difícil controle (MARCONDES; ROSSI, 2013). 
Segundo Zucchermaglio et al. (2015, p. 39) "ao conhecermos a cadeia epidemiológica da leishmaniose, a prevenção pode ser realizada de forma mais precisa e efetiva, já que poderemos atuar pontualmente em um segmento da cadeia". Vale ressaltar que a LVC não é transmitida por contato direto, portanto a via de eliminação é apenas o sangue de animais infectados transmitido através do repasto sanguíneo do flebótomo. A porta de entrada é a pele (COSTA, 2005). “Os hospedeiros susceptíveis podem ser animais silvestres, como roedores, gambás, tamanduás, tatus, canídeos, primatas e preguiças; e animais domésticos, como cães, gatos e equinos; além dos seres humanos." (ZUCCHERMAGLIO et al. 2015, p. 39).

\subsection{Patogenia e manifestações clínicas}

No hospedeiro, durante o repasto sanguíneo pelo flebótomo, há a inoculação das promastigotas, que logo são fagocitadas por células do sistema imunológico. Após serem englobadas pelos macrófagos, ocorre multiplicação por fissão binária, e na sequência ocorre uma ruptura da célula, liberando a forma amastigota (SILVA, 2019). Após a liberação destas formas, serão parasitados novos macrófagos havendo a ocorrência da disseminação para outros órgãos onde se encontram novas células do sistema imune como medula óssea, linfonodos, baço e fígado (BRASIL, 2014).

A LVC é caracterizada por inflamação granulomatosa e deposição de imunocomplexos nos órgãos. Quando o sistema hemolinfático é afetado, ocorre linfadenomegalia com presença de exsudato. Pode-se observar hipertrofias medulares e corticais dos linfonodos e, ainda, reação inflamatória no baço, além de hipertrofia de células medulares, resultando em uma grave anemia e trombocitopenia (MAIA, 2013).

Alterações podem acontecer no coração, como miocardite e inflamação linfohistioplasmocitária. Em relação aos rins, devido à alta deposição de imunocomplexos nos glomérulos, pode haver uma paralização das funções renais, causada por uma glomerulonefrite e uma nefrite intersticial (BRASIL, 2006). Já no intestino observa se uma descamação das mucosas gástricas devido a ulceração, causando uma diarreia crônica e uma grave inflamação (LUVIZOTTO 2006).

A LVC acomete também os olhos, o sistema nervoso central e os ossos, além de causar uma severa hemorragia devido ao sequestro esplênico de plaquetas. Nos olhos observa-se inflamação e lesões oculares com edema de córnea, íris e corpo ciliar, gerado 
pelo deposito de imunocomplexos. No sistema nervoso central acomete os neurônios manifestando sinais como: nistagmo, andar em círculo, tremor, letargia, mioclonia e paralisia de mandíbula. Nos ossos há lesões osteolitica e osteoproliferativas, progredindo a uma atrofia muscular (CONTRERAS et al. 2019).

Nos pulmões pode apresentar uma pneumonia intersticial, com a presença de um infiltrado linfoplasmocitário, apesar de não há possibilidade de uma transmissão horizontal (SILVA, 2007).

Estudos encontram também a presença de macrófagos contendo amastigotas em órgãos genitais de cães, gerando uma epididimite ou orquite no interstício (SOUZA et al. 2015). Entretanto além das enfermidades ocorrida em órgãos, gerada pela deposição de imunocomplexos, divido a baixa de imunidade do hospedeiro há a possibilidade de doenças oportunistas, como virais e bacteriana (CONTRERAS et al. 2019).

Clinicamente, os sinais clínicos da LV em cães são semelhantes aos dos humanos, porém no cão além de acometer os órgãos, são observadas feridas progressivas na pele. As apresentações clínicas da LVC podem ser variadas com período de incubação de 2 a 12 meses, e o que determinará cada uma estará relacionado a imunidade do animal no momento da infecção, a resistência do indivíduo e a cepa do parasita. Há a possibilidade de a doença ser assintomática, em que o período de incubação pode se prolongar, chegando até 25 meses (SILVA, 2007).

Alguns cães podem se recuperar havendo uma cura clínica espontaneamente, enquanto outros podem agravar gradativamente até a morte. Os sinais clínicos são inespecíficos podendo ocorrer da fase aguda a crônica. A fase aguda é caracterizada por manifestar sinais mais brando, enquanto na fase crônica são gerados sintomas graves podendo evoluir até a morte (FERREIRA, 2011).

\subsection{Achados Anatomopatológicos}

Dentre os achados anatomopatológicos encontrados no organismo dos cães infectados, podemos encontrar esplenomegalia com presença de macrófagos infectados com a forma amastigotas, nos linfonodos encontra-se lesões hipertróficas na região cortical, já na medula assim como os outros órgãos do sistema linfoide encontrase um quadro de hipertrofia. No coração há a presença de miocardite, além de necrose 
das fibras do miocárdio. Há presença de infiltrado inflamatório no fígado e na pele, apresentando inflamação e descamação. Além de alterações no intestino, pulmão e rins (MUNFORD, 2016).

\subsection{Diagnóstico}

A LVC em relação ao exame clínico é uma enfermidade de difícil diagnóstico, por apresentar uma grande variedade de sinais clínicos. No hemograma, as alterações encontradas são inespecíficas, tais como: anemia, trombocitopenia, linfopenia, leucocitose com desvio a esquerda são as alterações encontradas no hemograma de um cão com LVC. Já na bioquímica podemos encontrar um aumento de ureia, e a creatinina normal ou em alguns casos aumentados, e uma diminuição na albumina. Há a necessidade de confirmação por meio de outros métodos de diagnósticos (DOTTA et al. 2009; MAIA, 2013).

Dentre os exames de diagnósticos preconizados está o parasitológico, que é realizado por meio de material recolhido de preferência por medula óssea, em seguida vem a pele realizado por ser menos invasivo além dos linfonodos ou baço (BRASIL, 2017).

Os testes sorológicos podem ser utilizados, mas é importante saber que após a infecção em um período de aproximadamente 3 meses são liberadas imunoglobulinas IgG anti-Leishmania, que permanecem no organismo podendo alcançar até dois anos (SCHIMMING, SILVA, 2012). Dentre os exames sorológicos, são recomendados os ensaios imunoenzimáticos e a reação imunofluorescência indireta (RIFI) (BRASIL, 2009). Já o ELISA, é utilizado como teste triagem, devido à baixa possibilidade de um falso positivo, e uma alta eficiência (FERREIRA, 2011).

Para diagnostico parasitológico ou molecular a Reação de Cadeia de Polimerase (PCR), é a mais preconizada, com ele é possível observar DNA do parasito no resultado. O exame é realizado através de parte do tecido do animal infectado como: aspiração do líquido dos linfonodos, biopsia da pele, medula óssea, sangue ou cortes histológicos de tecidos. A maior dificuldade encontrada na realização desse exame é a demanda de um laboratório com equipe habilidade tecnicamente e muito bem equipado, gerando um alto custo para a realização (DOTTA et al. 2009). 


\subsection{Diagnóstico Diferencial}

Dentre as doenças que podem ser confundidas com a LVC, pode-se destacar a enterobacteriose de curso prolongado, devido a semelhança nas manifestações clínicas como hepatomegalia e edema de membros, além de laboratorialmente observar pancitopenia e hipergamaglobulinemia. Como diagnóstico diferencial elenca- se também dermatite esfoliativa e lúpus eritematosos, devido a feridas na pele, sendo fundamental a realização de biopsia. Se assemelham a LV outras patologias como brucelose, malária, febre tifoide, esquistossomose hepatoesplênica, mieloma múltiplo, linfoma etc. Sendo assim o diagnóstico confirmatório só poderá ser fechado com a realização de exames laboratoriais (BOSSLER, 2012).

\subsection{Tratamento}

No Brasil o tratamento da LVC e controverso e bem discutido, devido o cão ser o maior reservatório no meio urbano e rural acredita-se que ao tratar um cão infectado a doença pode persistir, pois o fármaco utilizado no tratamento não elimina totalmente a enfermidade aumentando o risco de propagar a doença para mais animais e seres humanos (MAIA, 2013).

Em 2008, dia 11 de julho o Ministério da Saúde e da Agricultura, Pecuária e Abastecimento (MAPA), proibiu a utilização de medicamentos do uso humano para o tratamento da LVC, através da portaria interministerial no 1.426. Existem países onde o tratamento é permitido, dentre os medicamentos de eleição utilizados estão os antimoniais pentavalente como: aminiosina, miltefosina, alopurinol e o anfoterecina B (YOUSSEF et al. 2019).

Diante da alta possibilidade de resistência aos medicamentos (por parte do protozoário) e da proibição do MAPA, foi realizado em estudo para a criação de um novo método de tratamento exclusivo veterinário. Recentemente houve o registro no mercado de um novo medicamento, de uso animal, a base de miltefosina, autorizado pelo MAPA/MS (ARAÚJO et al. 2018). Entretanto, o Ministério da Saúde (MS) informa que o tratamento da LVC não é uma medida eficaz em saúde pública. Sendo assim, a escolha do tratamento é exclusiva do proprietário do animal (BRASIL, 2018). 


\subsection{Medidas Profiláticas}

Para o controle e prevenção da LVC destaca no correto manejo do ambiente e ações de educação em saúde (BRASIL,2018). Portanto, para evitar os riscos de transmissão dessa enfermidade, algumas medidas profiláticas devem ser adotadas: controle populacional de cães, uso de malha fina nas janelas e portas de ambientes que tenham animais, coleiras com deltrametrina $4 \%$ e utilização de repelentes contra 0 inseto como também algumas medidas coletivas como: Limpeza de quintais e terrenos, eliminação dos resíduos como: matéria em decomposição, folhas, troncos e frutos podres dando a eles destinos adequados, eliminação de locais úmidos. (FERREIRA, 2011).

Existe uma vacina animal no mercado, porém seu uso não é totalmente indicado para o controle da LVC no Brasil. O MS alerta que esse imunobiológico não tem $100 \%$ de eficácia, recomendando que além da vacinação, que é opcional, os animais principalmente de áreas endêmicas devem usar a coleira com deltametrina (BRASIL, 2018).

Dentre ações realizadas para o controle e prevenção das leishmanioses, existe a vigilância entomológica criada com o propósito de identificar a ocorrência dos vetores, além de orientar a população sobre as medidas corretas para a prevenção contra o inseto. Por fim, caso haja algum caso confirmado em animais, o médico veterinário deve informar de imediato a vigilância epidemiológica para que os as atitudes cabíveis e corretas sejam realizadas (BRASIL, 2017).

\subsection{Aspectos relacionados à Saúde Pública}

O primeiro caso registrado de LV, no Brasil, foi em 1913. E seu relato se deu por meio da necropsia de um paciente oriundo de Boa Esperança/MT. Mais casos foram confirmados em um estudo retrospectivo com pacientes suspeitos de febre amarela, em que foram descobertos 41 casos de LV em indivíduos da região Nordeste (FERREIRA, 2011).

Houve um momento em que a LV acometia pessoas com um nível social menor, moradores de propriedades rurais, e com grande casuística na população nordestina. Com o passar do tempo a enfermidade se espalhou, acometendo todas as outras regiões brasileiras, apresentando um perfil urbano também (MARCONDES; ROSSI, 2013). 
Vale ressaltar que a sintomatologia humana possui aspectos parecidos com o do cão, contendo algumas poucas diferenças. Na LV humana não há feridas na pele, quando comparada com a LVC (BRANDÃO; MOTANHA, 2011). O diagnóstico baseia se nos mesmos exames e avaliação clínica realizados nos cães. O que difere é em relação ao tratamento, em que o medicamento de eleição é à base de antimoniato de metilglucamina (LISBOA et al. 2016).

Já as medidas profiláticas são baseadas em uso de mosquiteiro, uso de repelentes, telas nas portas e janelas, não sair em horários de atividade do vetor e em ambientes de predileção do flebotomíneo, além da notificação obrigatória de casos confirmados e a educação populacional sobre a enfermidade (BRASIL, 2017).

\section{REFERÊNCIAS}

ALVARENGA, D. G; ESCALDA, P. M. F; COSTA, A. S. V; MONREAL, M. T.F. D; Leishmaniose visceral: estudo retrospectivo de fatores associados à letalidade. Revista da Sociedade Brasileira de Medicina Tropical, Governador Valadares, v. 2, n. 43, p.194-197, mar. 2010.

ALVES, W. A. Leishmaniose visceral americana: situação atual no Brasil. Coordenação Geral de Doenças Transmissível: Departamento de Vigilância Epidemiológica. Secretaria de Vigilância em Saúde. Ministério da Saúde, Brasília DF, v. 71, n. 6, p.25-29, 2009

ANVERSA, L; MONTANHOLI, R. J. D; SABINO, D. L. Avaliação do conhecimento da população sobre leishmaniose visceral. Revista do Instituto Adolfo Lutz. Bauru SP. v. 75 n. 31 p. 1685-1690, jan. /2016.

ARAÚJO, C. M. C; COSTA, A. S; RISSO, J. M. R. Uso da miltefosina como terapia combinada em leishmaniose visceral canina - Relato de caso. Enciclopédia Biosfera, Goiânia, v. 15, n. 27, p.106-116, jun. 2018.

AZEVEDO, D. A; ARAÚJO, D. P; PAULA, E. M. N; CRUZ, C. A; SOUSA, D. B; MEIRELleSBARTOLI, R. B. Avaliação do conhecimento sobre leishmaniose dos docentes dos anos iniciais do ensino fundamental de escolas municipais de Jataí GO, brasil / evaluation of the knowledge about leishmaniasis of public school elementary teachers in jataí, go, brazil. Ars Veterinaria, v. 29, n. 4, p.103, 9 out. 2013. FUNEP. http://dx.doi.org/10.15361/2175-0106.2013v29n4p103.

BARATA, R. A; SILVA, J. C. F; MAYRINK, W; SILVA, J. C; PRTA, A; LOROSA, E. S; FIÚZA, J. A; GONÇALVES, C. M; PAULA, K. M; DIAS, E. S. Aspectos da ecologia e do comportamento de flebotomíneos em área endêmica de leishmaniose visceral, Minas Gerais. Revista da Sociedade Brasileira de Medicina Tropical, Centro de 
Pesquisas René Rachou da Fundação Oswaldo Cruz, Belo Horizonte MG, v. 38, n. 5, jun./jul. 2005.

BASTOS, T.S.A; Estudos introdutórios sobre flebotomíneos. 2012. 46f. Monografia (pôsgraduação em ciência animal) Universidade federal de Goiás escola de veterinária e zootecnia programa de, Goiânia.

BOSSLER, R. S; LEISHMANIOSE VISCERAL CANINA. 2012. 31 f. TCC (Graduação) - Curso de Medicina Veterinária, Universidade Federal do Rio Grande do Sul, Porto Alegre.

BRANDÃO, T. G. E; MONTANHA, F. P; LEISHMANIOSE VISCERAL - REVISÃO DE LITERATURA. Revista Científica Eletrônica de Medicina Veterinária, Garça, v. 2, n. 16, p.1-6, jan. 2011.

BRASIL, M. S; Secretaria de Vigilância em Saúde. Departamento de Vigilância Epidemiológica. Manual de vigilância e controle da leishmaniose visceral / Ministério da Saúde, Secretaria de Vigilância em Saúde, Departamento de Vigilância Epidemiológica. - Brasília: Editora do Ministério da Saúde, 2006.

BRASIL, M. S. Manual de vigilância e controle da leishmaniose visceral. Brasília: Ministério da Saúde. 2009. 120p.

BRASIL. Ministério da Saúde. Secretaria de Vigilância em Saúde. Departamento de Vigilância Epidemiológica. Manual de vigilância e controle da leishmaniose visceral / Ministério da Saúde, Departamento de Vigilância Epidemiológica. - 1. ed., 5. reimpr. - Brasília: Ministério da Saúde, 2014.

BRASIL, Ministério da Saúde. Secretaria de Vigilância em Saúde. Coordenação- Geral de Desenvolvimento da Epidemiologia em Serviços. Guia de Vigilância em Saúde: volume 3 / Ministério da Saúde, Secretaria de Vigilância em Saúde, CoordenaçãoGeral de Desenvolvimento da Epidemiologia em Serviços. - 1. ed. atual. Brasília: Ministério da Saúde,2017.

BRASIL, Ministério da Saúde. Secretaria de Vigilância em Saúde. Departamento de Vigilância Epidemiológica. Guia de orientação para a vigilância da leishmaniose visceral canina (LVC). Ministério da Saúde, Secretaria de Vigilância em Saúde, Departamento de Vigilância Epidemiológica. Santa Catarina - 2018.

BRASIL. Ministério da Saúde. Leishmaniose Visceral em Goiás - Aspectos epidemiológicos Boletim epidemiológico, Goiânia, v.18, n.3, out.2017.

BRITO, J. A; SANTOS, R. A; MENDONÇA, B. C. Avaliação do conhecimento sobre a leishmaniose visceral antes e depois de intervenção educacional em proprietários de cães da cidade de cruz das almas, recôncavo da Bahia. Revista Ciência em Extensão. Cruz das Almas. v.11, n.2, p.104-114, 2015. 
CAMARGO, T. C; BONDAN, E. F; Conhecimento sobre leishmaniose visceral canina na população do município de Cotia (SP), Brasil, e participação dos clínicos veterinários locais na propagação de medidas preventivas. Revista bras. São Paulo, v. 22 n. 1 p. 28-33, maio, 2014.

CONTRERAS, I. K; MACHADO, M. A; ROCHA, C. O. J. M; OLIVEIRA, G. R; CARVALHO, F. C. $G$; Sinais clínicos apresentados por cães positivos para leishmaniose visceral no município de Vassouras, Rio de Janeiro. Pubvet, Vassouras, v. 4, n. 13, p.2-6, abr. 2019.

COSTA, J. M. L. Epidemiologia das Leishmanioses no Brasil. Gazeta Médica da Bahia, Salvador, v. 1, n. 75, p.3-17, jan. 2005.

DOTTA, S. C. N; LOT, R. F. E; ZAPPA, V. Métodos de diagnóstico da leishmaniose visceral canina. Revista Científica Eletrônica de Medicina Veterinária, Garça, v. 12, n. 8, p.1-5, jan. 2009.

ESCOBAR, T. A. DUARTE, C. A; DOWICH, G; MANFREDINI, V; LUBECK, Hospedeiros de leishmania Spp. na região sul do brasil. 2018. 5 f. Monografia (Especialização) Curso de Salão Internacional de Ensino, Pesquisa e Extensão, Universidade Federal do Pampa, Santana do Livramento.

FERNANDES, C. B., JUNIOR, J. T. M., JESUS, C., SOUZA, B. M. P. S., LARANGEIRA, D. F., FRAGA, D. B. M., BARROUIN-MELO, S. M. (2014). Comparison of two commercial vaccines against visceral leishmaniasis in dogs from endemic areas: IgG, and subclasses, parasitism, and parasite transmission by xenodiagnosis. Vaccine, 32(11):1287-1295.

FERREIRA, J. L. Leishmaniose Visceral Canina (LVC). 2011. 33 f. TCC (Graduação) - Curso de Bacharel em Medicina Veterinária, Universidade Paulista, São José dos Campos.

FREITAS, B. R; RABELO, E. L; BORGES K. I. N; SOUZA, K. A; FRANSOSI, J. M. Estudo epidemiológico dos casos de leishmaniose em humanos e cães no município de Mineiros -Goiás.in: IX Semana universitária e VII e Encontro de iniciação científica: Sustentabilidade, Economia Verde e Erradicação da Pobreza. 2014.

GONTIJO, C. M. F; MELO, M. N. Leishmaniose Visceral no Brasil: quadro atual, desafios e perspectivas. Revista Brasileira Epidemiológica, São Paulo, v. 7, n. 3, 200. /mar. 2004.

GUIMARÃES E. L. A. M. Conhecimento sobre leishmaniose visceral e prática das medidas de prevenção e controle por proprietários de cães em Belo Horizonte, 2010/2011. 2013. 81 f. Dissertação (Mestre em Ciência Animal). Colegiado do Programa de Pós-Graduação, Universidade federal de minas gerais escola de veterinária, Belo Horizonte MG. 
LISBOA, A. R; PINHEIRO, A. A. V; DANTAS, A. E. F; OLIVEIRA, I. B; EVANGELISTA, T. R; PEREIRA, K. K. E. A. Leishmaniose visceral: Uma revisão literária. Revista Brasileira de Educação e Saúde, Pombal, v. 6, n. 2, p.35-43, 28 dez. 2016.

LOBO, K. S; BEZERRA, J. M. T; BRITO, L. M. O; SILVA, J. S; PINHEIRO, V. C. S; Conhecimentos de estudantes sobre Leishmaniose Visceral em escolas públicas de Caxias, Maranhão, Brasil. Revista Ciência \& Saúde Coletiva. Caxias MA. v. 18 n.8 p.2295-2300, 2013.

LUCENA, R. V; MEDEIROS, J. S. Caracterização epidemiológica da leishmaniose visceral humana no nordeste brasileiro entre 2010 e 2017. Revista. UEPB. Campina Grande. v. 14, n. 4, out/dez 2018.

LUVIZOTTO, M.C.R. Alterações patológicas em animais naturalmente infectados. In: 1을 Fórum sobre leishmaniose visceral canina, 2006, Jaboticabal. Anais do Fórum de Leishmaniose Visceral canina 2006. p.15-22.

MAIA, L. S. Leishmaniose visceral canina: Aspectos clínicos e hematológicos de casos suspeitos e confirmados atendidos no Hospital Veterinário da Universidade de Brasília em 2011. 2011. 27 f. Monografia (Especialização) - Curso de Medicina Veterinária, Universidade de Brasília, Brasília.

MARCONDES, M. ROSSI, C. N. Leishmaniose visceral no Brasil. Revista Brazilian Journal Veterinary Research and Animal Science. São Paulo, v. 50, n. 5, p.341- 352, 30 out 2013.

MASSIA, L. I. Leishmaniose visceral: avaliação do conhecimento dos agentes de saúde pública em Uruguaiana (RS). 2017. 87 f. Dissertação (Pós-graduação Stricto Sensu em Ciência Animal) - universidade federal da pampa. Uruguaiana.

MEIRELLES-BARTOLI, R.B; SOUSA, D.B; PAULA, E.M.N; CRUZ, C.A; MORAES, F.C; NASCIMENTO, K.A; ARAÚJO, D.P; AZEVEDO, D.A; COSTA FILHO, R.I. Percepção dos professores da rede pública municipal de ensino do município de jataí - go sobre a prevenção da leishmaniose. In: II Simpósio Sul-Mineiro doenças negligenciadas. 2015. Minas Gerais. Anais do II Simpósio Sul-Mineiro de Doenças Negligenciadas. 2015. p. 47.

MUNFORD, N. D. Alterações histopatológicas em cães com leishmaniose visceral naturalmente infectados do município de Jequié-BA (Brasil). 2016. $93 \mathrm{f}$. Dissertação (Mestrado) - Curso de Pós-graduação em Patologia, Universidade Federal da Bahia Fundação Oswaldo Cruz Faculdade de Medicina Centro de Pesquisas Gonçalo Moniz, Salvador.

MUTZEMBERG, E. R; ALMEIDA, A. B. P. F; SOUSA, V. R. F. Como os médicos veterinários de Cuiabá/MT encaram a leishmaniose visceral canina? Revista Eletronica De Extensão. Florianópolis, v.9, n.13, p.32-41, 2012. 
PAULA, E. M. N. Distribuição espacial da leishmaniose visceral no estado de São Paulo, Brasil, no período de 1970 a 2014. 2016. 44 f. Dissertação (Mestrado) - Curso de Medicina Veterinária, Universidade Estadual Paulista - Unesp, São Paulo, 2016.

PAULA, E.M.N; PAULA, C.R; PRESOTTO, L.G; BARTOLI, D.S; MEIRELLES-BARTOLI, R.B. Pesquisa entomológica de flebotomínios no município de Jataí-Go após diagnóstico do primeiro caso alóctone de leishmaniose visceral canina. In: II Simpósio Sul-Mineiro doenças negligenciadas. 2015. Minas Gerais. Anais do II Simpósio Sul-Mineiro de Doenças Negligenciadas. 2015. p. 27.

PAULAN, S. C; SILVA, D. T; LINS, A. G. S; LIMA, F. L; TENÓRIO, M. S; TASCA, K. I; PANOSSO, A. R; STARKE-BUZETT, W. A. O conhecimento sobre leishmaniose visceral: suficiente para controle e prevenção? Revista Ciência em Extensão. São Paulo. v.12, n.2, p.47-60, 2016.

PITA-PEREIRA, D. CARDOSO, M. A; ALVES, C. R; BRASIL, R. P; BRITO, C. Detection of natural infection in Lutzomyia cruzi and Lutzomyia forattinii (Diptera: Psychodidae. Acta tropica, Rio de Janeiro, v. 107, n. 1, p.66-69, 2008.

QUEIROZI, M. F. M. et al. Análise da fauna flebotomínica (Diptera: Psychodidae) em Barra do Garças, Estado de Mato Grosso, Brasil, e a influência das variáveis ambientais na densidade vetorial de Lutzomyia longipalpis. Revista da Sociedade Brasileira de Medicina Tropical, Setor de Vigilância em Saúde Ambiental, Secretaria de Estado de Saúde de Mato Grosso, Cuiabá, MT, v. 45, n. 3, p. 313317, jun. 2012.

SCHIMMING, B. C; SILVA, J. R. C. P. LEISHMANIOSE VISCERAL CANINA: Revisão de literatura. Revista Científica Eletrônica de Medicina Veterinária, São Paulo, v. 19, n. 1, p.1-17, jul. 2012.

SILVA, F. S. Patologia e patogênese da leishmaniose visceral canina. Revista Trópica: Ciências Agrárias e Biológicas, Boa Vista, v. 1, n. 1, p.20-31, fev. 2007.

SILVA, K. L. O; SANTOS, D. P; COELHO, N. M. D; SILVA, D. C.; OKAMOTO, A C; JARDIM JÚNIOR, E. G. Vacinas Contra Leishmaniose: Uma Revisão. Arch Health Invest. São Paulo, v 2 n 4, p. 18-28, 2013.

SILVA, L. L. Campanhas educativas sobre a leishmaniose visceral em escolas públicas do município de Codó-MA. 2019. 35 f. Monografia (Especialização) - Curso de Licenciatura em Ciências Natural, Universidade Federal do Maranhão, Codó, 2019. Cap. 11.

SILVA, J. E. OLIVEIRA, I. N; BARBOSA, J. P. F; LIBRA, T. P. S; LIMA, A. M. S; SANTOS, C. B. Epidemiologia da Leishmaniose Visceral Canina no município de Taquarana - AL (2009-2018). Diversitas Journal, Arapiraca, v. 4, n. 2, p.393-402, 19 maio 2019. 
SOUSA, T. C; FRANCISCO, A. K. P. R; SANTOS, I. B. Leishmaniose Canina em Brasília, DF: Uma Revisão da Literatura. 2015. 16 f. TCC (Graduação) - Curso de Saúde Coletiva, Unb, Faculdade de Ceilândia, Brasília.

ZUCCHERMAGLIO, C; IZOLA, B.F; FONSATTI, F.G; MAIROS, F.S; TOSCANO, J.H.B; MARQUIZZEPPE, L.M.S; ALBINO, L; OLIVARI, M.B.D; MARQUES, N.C; SARTESCHI, N.P; PAULA, E.M.N; BARTOLI, R.B.M. Cadeia epidemiológica das leishmanioses. In: II Simpósio Sul-Mineiro doenças negligenciadas. 2015. Minas Gerais. Anais do II Simpósio Sul-Mineiro de Doenças Negligenciadas. 2015. P.39.

YOUSSEF, A. G; LIUTTI NETTO, L; TUANI, B. R. V; SERDIM, J. M. P; TEIEIRA, D. B; POLIGATO, E. P. S; PORTO, C.D; FRIOLANI, M. Conhecimento populacional sobre leishmaniose no município de Marília, São Paulo, Brasil. Revista Acadêmica Ciência Animal, Marília, v. 5, n. 8, p.1-7, 12 fev. 2019. 


\section{CAPÍTULO XII}

\section{TRIATOMÍDEOS DO BRASIL E SUA IMPORTÂNCIA EM SAÚDE}

DDI: 10.51859/amplla.pdi443.1121-12

Robert Deiverson Oliveira ${ }^{1}$

Gabriel Brom Vilela ${ }^{2}$

Valucia Teodoro Pereira ${ }^{3}$

Eric Mateus Nascimento de Paula ${ }^{3}$

${ }^{1}$ Médico Veterinário Autônomo. Egresso do Curso de Medicina Veterinária do Centro Universitário de Mineiros UNIFIMES

2 Docente da Universidade Estadual de Goiás - UEG, Unidade Mineiros.

${ }^{3}$ Docente do Curso de Medicina Veterinária do Centro Universitário de Mineiros - UNIFIMES.

\section{REVISÃO DE LITERATURA}

\subsection{Caracterização dos triatomíneos}

Os triatomíneos são insetos da subfamília Triatominae, conhecidos popularmente no Brasil como barbeiros, eles pertencem ao filo Arthropoda (simetria bilateral, pernas articuladas e um exoesqueleto); subfilo Mandibulata (mandíbulas e antenas); classe Insecta (um par de antenas, cabeça, tórax, abdômen e pernas articuladas); subclasse Pterigota (asas desenvolvidas); ordem Hemiptera (aparelho bucal picador sugador); subordem Gymnocerata (antenas visíveis e grandes); superfamília Reduvidoidea e família Reduviidae (cabeça mais comprida do que larga, olhos destacados e separados pela região interocular e pós ocular e ocelos que podem ser salientes ou achatados (DE OLIVEIRA e CONDURU, 2004; GALVÃO et al., 2014; SILVA, 2010; DE GRADUAÇÃO, 2007; LIMA-COSTA, 1952).

São caracterizados por serem hospedeiros do protozoário flagelado Trypanosoma cruzi, agente etiológico da doença de Chagas que ocorre principalmente na América, o que a faz ser conhecida também como Tripanossomíase Americana (GALVÃO et al., 2014).

Jorge e Castro (2000) trazem, que os triatomíneos são insetos hematófagos em todas as fases de desenvolvimento, desde a fase de ninfa até a fase adulta, tanto os 
machos como as fêmeas, fator significativo na transmissão da doença de Chagas, que ocorre no decorrer ou após a picada, quando o inseto se alimenta e realiza suas fezes, se ele estiver infectado, transmite o Trypanosoma cruzi ao hospedeiro podendo esse ser humano ou animal.

Taylor et al., (2017) relatam que os triatomíneos possuem hábitos noturnos, permanecendo escondidos em fendas e frestas durante o dia, vivem em habitações humanas ou próximas a elas. Os hospedeiros desses insetos podem ser humanos, cães, gatos, caprinos, bovinos, ovinos e mamíferos selvagens. Villela et al., (2005) afirmam que os triatomíneos são insetos que tem como habitat natural áreas silvestres, mas que por conta dos desmatamentos e o forte abito social de criar animais tais como galinha, porco e cachorro, faz com que o barbeiro se aproxime para as regiões peridomiciliares, habitando próximo ao ser humano.

Os triatomíneos apresentam três fases de evolução (ovo, ninfa e adultos), as ninfas têm um total de 5 estágios, podendo ser diferenciadas dos adultos pelo fato de não apresentarem asas e nem órgãos genitais. As fêmeas realizam a oviposição dos ovos 2 semanas posterior a cópula tendo um período de incubação equivalente de 15 a 30 dias. O ciclo evolutivo completo desde ovo até a fase adulta pode levar cerca de 2 a 3 meses, mas também dependendo da espécie até 2 anos (FIOCRUZ, 2011; TAYLOR et al., 2017).

Figura 1 - Diferenciação dos Gêneros dos Triatomíneos

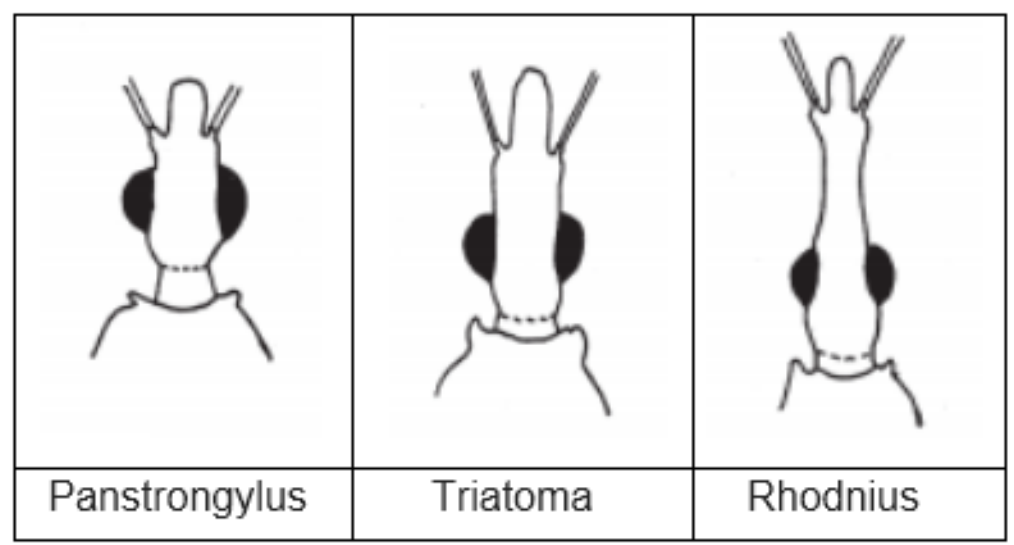

Fonte: JORGE e CASTRO, 2000

Brasil (2017) traz que os triatomíneos normalmente depositam seus ovos no ambiente, porém alguns contém uma substância adesiva, que disponibiliza aderência com folhas e objetos adjuntos ao local, uma vez que se ovos forem aderidos a penas de 
uma ave por exemplo, este pode ser transportado para lugares diferentes, característica muito importante, facilitando assim a dispersão da espécie.

Dentro das espécies de triatomíneos, podemos encontrar o agrupamento de vários gêneros, sendo que os mais relevantes em relação a transmissão da doença de Chagas são: Gênero Triatoma (cabeça de tamanho médio, e antenas entre os olhos e o alto da cabeça), onde o mesmo possui cerca de 69 espécies; Gênero Panstrongylus (cabeça curta e robusta e antenas na região anterior aos olhos) possuindo 13 espécies; e Gênero Rhodnius (cabeça alongada e antenas junto ao ápice da cabeça), tendo 13 espécies (JORGE e CASTRO, 2000).

Ao todo são 148 espécies espalhadas pelo mundo as quais são denominadas de triatomíneos, onde são apontadas como principais vetores o Triatoma infestans, Triatoma brasiliensis, Triatoma dimidiata, Rhodnius prolixus e Panstrongylus megistus. No Brasil se está contabilizado 65 espécies, nos quais as que tem mais relevância nas transmissões domiciliares são: Triatoma infestans, Triatoma pseudomaculata, Triatoma brasiliensis, Panstrongylus megistus e Triatoma sórdida (GALVÃO et al., 2014; VALENTE, 2011).

\subsection{Características dos principais vetores}

Os triatomíneos são insetos que possuem grande semelhança entre si, no entanto dispõem de dimensões e cores variadas, sob o aspecto de algumas manchas espalhadas em várias partes do corpo, o que permite entre outros aspectos diferenciar espécies (JORGE e CASTRO, 2000).

\subsubsection{Triatoma infestans}

O termo infestans é originário do Latim "infesto, infestare e infestatus" que tem como significado infestar, perturbar e prejudicar. O comprimento dos machos varia de 21 a $26 \mathrm{~mm}$, quanto ao das fêmeas é de 26 a $29 \mathrm{~mm}$. Sua coloração é na maior parte escura, sendo negra ou castanho escuro, possui também pontos amarelados nas pernas, conexivo e cório. Possui revestimento epidérmico curto e espalhado. Apresenta cabeça negra e rugosa e seu comprimento é duas vezes maior que sua largura (GALVÃO et al., 2014).

FIOCRUZ (2015) relata que o Triatoma infestans foi erradicado em quase todo o território nacional, através dos programas de controle, no entanto ainda se é possível 
encontrar pequenos focos residuais em algumas regiões do Rio Grande do Sul e da Bahia.

É uma espécie de característica domiciliada, com pequenos focos silvestres, vivem em residências, principalmente em telhados feitos de palhas, fendas em paredes, embaixo de caixas, colchões ou até mesmo atrás de objetos que podem estar sob ou pendurado nas paredes. Além disso habitam em ambientes próximos as casas onde residam animais, como por exemplo galinheiros e currais, podem ser encontrados também sob pedras, folhas ou tocos que fiquem conjunto a esses locais (JORGE e CASTRO, 2000).

Figura 2 -Triatoma infestans

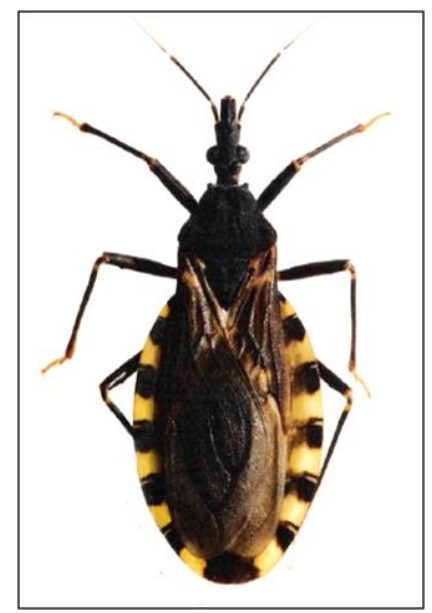

Fonte: GALVÃO et al., 2014

\subsubsection{Triatoma brasiliensis}

O Triatoma brasiliensis é específico do Brasil, por isso o termo brasiliensis, e atualmente é considerado a principal espécie na transmissão vetorial da Doença de Chagas ao ser humano, sobretudo na região nordeste do país (GALVÃO et al., 2014).

Foratini (1980) traz que a espécie suporta climas secos e temperaturas elevadas, podendo ainda se desenvolver de forma rápida mesmo em regiões secas como no Nordeste. São insetos que habitam em ambientes silvestres, o que torna mais difícil sua contenção, pois mesmo após o controle com inseticidas eles podem retornar e alocar as áreas controladas (ALENCAR, 1987).

A coloração do Triatoma brasiliensis consiste em castanho escuro a negro com algumas manchas amareladas, a cabeça é totalmente escura. Os machos variam de 22 a $25 \mathrm{~mm}$ de comprimento e as fêmeas de 23 a $25,5 \mathrm{~mm}$. Trata-se de uma espécie 
domiciliada mais que pode ser encontrada também no peridomicilio e no meio silvestre onde geralmente ficam dentro ou sob buracos de pedras que possuem a presença de roedores (JORGE e CASTRO, 2000).

Figura 3 - Triatoma brasiliensis

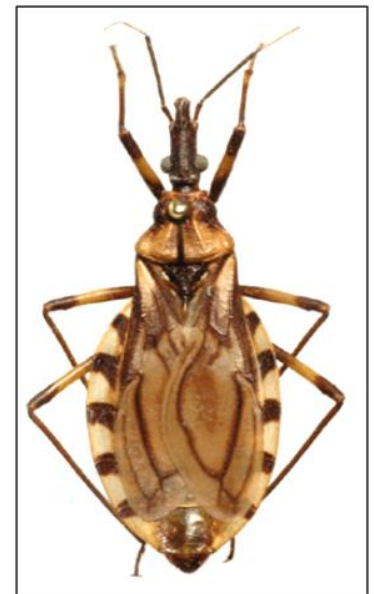

Fonte: GALVÃO et al., 2014

\subsubsection{Triatoma dimidiata}

Considerada de todas as espécies a mais variável, possuindo alta variabilidade cromática e corpórea. Se caracterizam por apresentarem coloração de castanho-escuro a preto, cório e conexivo de alaranjado a amarelo pálido, com revestimento epidérmico curto e imperceptível, cabeça dorsalmente enrugada (MELO, 2008).

São insetos capazes de viver em qualquer lugar, adaptando-se facilmente a diversos meios, incluindo áreas externas e internas de residências como também áreas silvestres. Pode ser encontrado em cavernas com morcegos, rochas, ninhos de animais, e também buracos de arvores, se alimentando principalmente do sangue de mamíferos, repteis e aves. (DUMONTEIL, et. al. 2002; ZELEDON, 1981). 
Figura 4 - Triatoma dimidiata

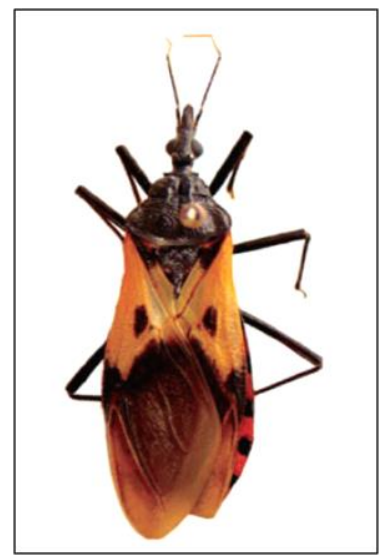

Fonte: MELO, 2008.

\subsubsection{Rhodnius prolixus}

Rhodnius prolixus tem destaque por ser considerado o principal vetor da doença de Chagas em alguns pontos da América Central e América do Sul como Venezuela, Guiana Francesa e Colômbia, podendo ser encontrado em dezesseis países da América Latina (JULBERG e GALVÃO, 2006).

São espécies que se destacam e são caracterizadas como sugadoras de sangue, sugando principalmente roedores, aves e morcegos, em geral habitam em buracos de arvores e folhagens de palmeiras. Possuem rápido ciclo de desenvolvimento, antropofilia intensa, densidade alta, prática de defecar logo após ingestão alimentar e elevada dispersão (FALCONE, 2016).

Os machos possuem comprimento de aproximadamente $17,20 \mathrm{~mm}$ enquanto as fêmeas variam de 19,5 a $21,5 \mathrm{~mm}$. O inseto Rhodnius prolixus é muito similar ao Rhodnius robustus sendo até difícil diferenciá-los. Possuem a mesma coloração sendo no geral castanho amarelado com várias manchas no corpo e apêndices na cor castanho escuro. A diferença entre os dois está na ninfa do Rhodnius prolixus que possui coloração das tíbias posteriores mais escuras do que as ninfas do Rhodnius robustus (GALVÃO et al., 2014). 
Figura 5 - Rhodnius prolixus

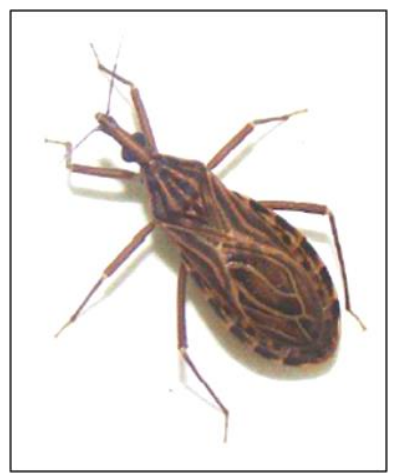

Fonte: PONTE, 2010

\subsubsection{Panstrongylus megistus}

Megistus vem do grego "megisto" o que tem como significado o termo maior. Os machos possuem comprimento de 26 a $34 \mathrm{~mm}$, enquanto as fêmeas de 29 a $38 \mathrm{~mm}$. São caracterizados pela coloração negra com manchas alaranjadas ou vermelhas em algumas partes do corpo, possuem cabeça totalmente escura sendo que seu comprimento é quase duas vezes maior que sua largura (GALVÃO et al., 2014).

O habitat dos Panstrongylus megistus é basicamente em palmeiras e ocas de arvores, em domicílios esse triatoma permanece intra e peridomiciliar, onde regularmente habitam em lugares com facilidade de se alimentarem como abrigos de animais, incluindo galinheiros, pocilgas, tocas e ninhos. Se alimentam de sangue principalmente de aves e roedores (PAULA et. al., 2010; BELISÁRIO et. al., 2013; SANTOSJUNIOR et. al., 2013; FIOCRUZ, 2015).

Figura 6 - Panstrongylus megistus

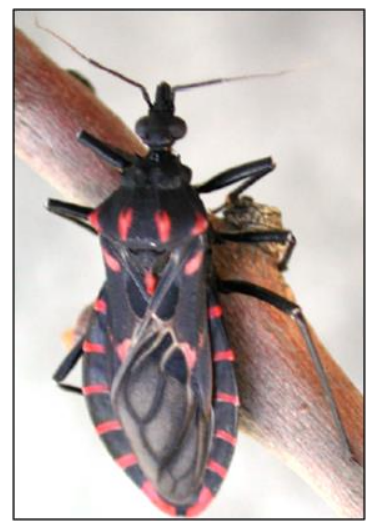

Fonte: GALVÃO, 2014 


\subsubsection{Triatoma pseudomaculata}

Trata-se de uma espécie com suma importância regional, podendo ser encontrada em grande escala na região Nordeste, seguida da Centro Oeste e uma pequena parte da região Sudeste. Têm por costume residirem dentro e próximos de casas, como por exemplo em pombais, currais, galinheiros e cercas construídas com galhos secos (FIOCRUZ 2015).

Figura 7 - Triatoma pseudomaculata

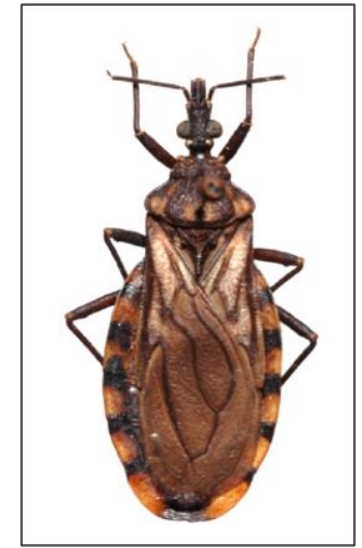

Fonte: GALVÃO et al. (2014)

São insetos que possuem coloração de castanho escuro a negro, com pequenas partes manchadas, podendo ser alaranjadas, amareladas ou avermelhadas. Os machos têm comprimento de 17 a 19 mm, e as fêmeas de 19 a 20mm (GALVÃO et al., 2014).

\subsubsection{Triatoma sordida}

Atualmente o Triatoma sordida é a espécie mais capturada com frequência perto das residências no Brasil, sendo encontrado em quase todo o território nacional, sua distribuição se dá nas regiões do Nordeste, Centro Oeste, Sudeste e também na região Sul (GALVÃO et al., 2014).

Esse inseto tem como habitat galinheiros, currais, pombais, palmeiras, ocos de arvores e também pilhas de lenhas. Sua coloração é basicamente do castanho claro ao castanho escuro, possuindo também manchas na cor amarelo claro em algumas partes do corpo. O comprimento dos machos é de 14 a 19mm, enquanto das fêmeas é de 15 a 20 mm (CARCAVALLO et. al., 1998; GALVÃO et al., 2014). 
Figura 8 - Triatoma sordida

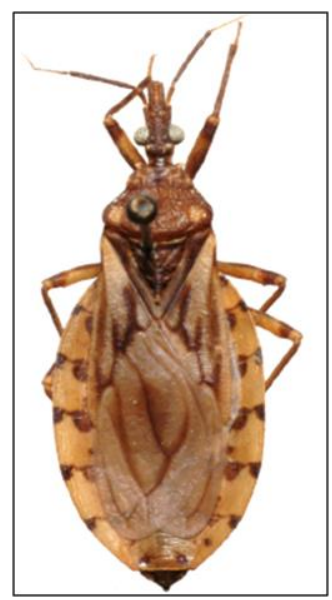

Fonte: GALVÃO et al., 2014

\subsection{Tripanosoma cruzi}

São hemoflagelados que pertencem a família Trypanosomatidae, gênero Trypanosoma, filo Euglenozoa e ordem Kinetoplastida. Possuem aproximadamente 150 espécies descritas e que são divididas em duas secções, sendo elas: Stercocaria onde sua transmissão ocorre por fezes e pode ser representada por exemplo pelo Trypanosoma cruzi e Salivaria que é transmitida através das glândulas salivares e tem como exemplo o Trypanosoma briicei (EMBRAPA, 2002; NEVES, 2016).

Esse protozoário manifesta formas evolutivas, onde três são mais visíveis, sendo elas: a forma amastigota, que é aflagelada e encontrada dentro das células do hospedeiro; a forma epimastigota, que é flagelada e se encontra no tubo digestivo dos vetores; e as formas tripomastigotas, também flageladas e que circulam na corrente sanguínea dos vertebrados e no tubo digestivo dos triatomíneos (COURA, 2007).

Possuem membranas ondulantes em seu corpo, o que facilita sua movimentação na corrente sanguínea. São protozoários que só infectam mamíferos, pois não conseguem se desenvolver no sangue de repteis, aves ou anfíbios. Anteriormente a circulação do Trypanosoma cruzi era limitada apenas ao meio silvestre, em mamíferos e barbeiros, porém a aproximação do barbeiro a zona urbana fez com que a infecção ao homem se tornasse possível (GALVÃO et al., 2014).

Dentro das espécies dos Trypanosomas, duas possuem grande importância epidemiológica a nível mundial, uma sendo o Trypanosoma cruzi agente etiológico da doença de Chagas ocorrente nas Américas e o Trypanosoma brucei que ocasiona a doença do sono e atinge a África (NEVES, 2016). 


\subsection{Origem e história da doença de Chagas}

A doença de Chagas é considerada uma endemia de grande relevância na América Latina, tendo marco histórico na medicina e que é memorável até os dias de hoje, devido ao grande cientista Carlos Chagas que além de descobrir a doença até então desconhecida, identificou seu protozoário etiológico e maneiras de se transmitir a doença (JORGE e CASTRO, 2000).

Sua descoberta se deu no norte do Estado de Minas Gerais, sudeste do Brasil, quando o médico Carlos Chagas foi enviado pelo Instituto Oswaldo Cruz para dar suporte no controle de uma epidemia de malária que havia se instalado no Estado. Após o controle do surto de malária ele se deparou com um inseto, o qual lhe foi apresentado como barbeiro e que era comum de ser encontrado dentro das casas na região, além de sugar sangue de gente e de animais, fator que fez com que ele resolvesse pesquisar a probabilidade desse inseto transmitir algum tipo de enfermidade, visto que ele encontrara diversos quadros clínicos de difíceis explicações, onde as pessoas apresentavam arritmias e insuficiência cardíacas além de terem morte súbita (COUTINHO e DIAS, 1999).

Ao analisar os barbeiros, Carlos Chagas encontrou flagelados dentro do intestino de um dos insetos, o qual ele enviou para Oswaldo Cruz, e a partir daí começou a se fazer experimentos em alguns macacos não infectados e após análises e estudos podese verificar um novo protozoário o qual foi denominado por ele, Trypanosoma cruzi em homenagem a Oswaldo Cruz (FITARELLI e HORN, 2008).

No ano de 1909, Carlos Chagas encontrou o mesmo protozoário que havia encontrado nos insetos, no sangue de uma menina de 2 anos de idade, que estava febril. A mãe da menina relatou que ela tinha sido sugada por um barbeiro e ao informar os sintomas a Chagas, o mesmo notou coincidência com os dos animais de laboratório usados nas experiências. Desde então, Carlos Chagas foi capaz de relatar uma nova doença, como também descobriu seu protozoário, seu reservatório além dos meios de transmissão (NEVES et al., 2005; JORGE e CASTRO, 2000).

A fase aguda da doença pode ser aparente ou inaparente, sendo que essa se inicia quando o Trypanosoma cruzi penetra na conjuntiva ou na pele e manifesta sinais locais conhecidos como porta de entrada, sendo eles, sinal de romana (edema inflamatório bipalpebral) ou sinal de chagoma de inoculação (lesões nodulares). As 
principais manifestações clínicas podem ser representadas por febre persistente, edemas cutâneo, manifestações hemorrágicas e sinais de insuficiência cardíaca (NEVES, 2016; RASSI-JUNIOR et al., 2010; BRASIL, 2017).

A forma crônica da doença é assintomática e os pacientes possuem poucos sinais da infecção. Acredita-se que a fase crônica se manifesta em cerca de $30 \%$ dos pacientes que possuem a infecção na fase aguda. (BRASIL, 2017, COURA, 2007).

As formas frequentes de transmissão do Trypanosoma cruzi, podem ser diversas, sendo que a principal forma é a transmissão vetorial, responsável por cerca de $80 \%$ das infecções existentes. Esse meio de transmissão está ligado a muitos fatores, podendo ser afetados pela qualidade das moradias e as ações do ser humano sobre o ambiente peri e domiciliar. Para que ela aconteça são necessários triatomíneos domiciliados, a presença do agente etiológico da doença e necessita do hospedeiro que pode ser humano ou outros animais que vivem no ambiente domiciliar (GALVÃO et al., 2014; DIAS, 2001).

Outras maneiras de transmissão da doença é a ingestão oral de alimentos contaminados, acidentes laboratoriais, transfusão sanguínea, via transplacentária onde mãe infectadas transmitem o parasito aos filhos no parto ou durante a gestação, e o manejo de carcaças infectadas. Atualmente muitos surtos de infecção por via oral da doença de Chagas tem sido motivo de alerta, principalmente relacionando o consumo de açaí e do caldo de cana, que são processados juntamente com fezes contaminadas dos insetos e até mesmo os próprios insetos triturados (DIAS, 2006; APT et al., 2013; NÓBREGA et al., 2009; SHIKANAI-YASUDA e CARVALHO, 2012; BENÍTEZ et al., 2013; SEGOVIA et al., 2013; SOUZA-LIMA et al., 2013; SOTO et al., 2014).

Muitos fatores são determinantes para a transmissão do Trypanosoma cruzi ao homem, podendo citar como exemplo, migrações fora de controle, desmatamento, mudanças climáticas, altos índices de pessoas em áreas urbanas, habitações precárias, falta de saneamento, condições socioeconômicas precárias entre outras (WHO, 2012; PINTO DIAS, 2013; PRATA, 2001; COURA, 2015).

Brasil (2017) traz que a doença de Chagas se trata de uma antropozoonose de grande preponderância e índices de mortalidade expressivos, apresentando em seu curso clínico duas fases, podendo esta ser aguda ou crônica e que se não tratada certamente levara a óbito. Essa antropozoonose corresponde a um problema de saúde 
pública de grande relevância no Brasil, pois é uma doença que ainda é negligenciada e é capaz de impactar pontos econômicos, sociais e psicológicos, atingindo diversos cenários regionais do país (DIAS, 2015).

Para Dias (2000) a doença de Chagas ainda reflete em uma problemática social, especificadamente nos países afetados onde a doença segue desconhecida e com carência de programas afim de controlar o surto. Podendo destacar ainda a necessidade de controle e mudanças até mesmo nos países onde a endemia já foi minimizada, pois requer uma atenção em especial para aqueles que já foram infectados, aplicando assim um sistema de saúde mais objetivo e eficiente.

Neves (2016) afirma que mesmo com os progressos alcançados em relação a doença de Chagas, na América Latina, 18 países enfrentam a transmissão da doença, sendo que em 22 países ainda existe a presença dos principais vetores. No Brasil ela está distribuída em uma área de aproximadamente 3 milhões de $\mathrm{km}^{2}$, abrangendo desde a região norte até a região sul do país, do Maranhão até o Rio Grande do Sul. No meio silvestres ainda pode-se encontrar reservatórios e vetores infectados, que estão espalhados por todo o território nacional, sendo assim o risco de infecção ainda é eminente envolvendo mais de 20 milhões de pessoas.

\subsection{Características epidemiológicas}

A doença de Chagas é considerada uma zoonose que ainda carece de muita atenção e é encarregada por cerca de 8 milhões de pessoas estarem infectadas pelo protozoário Trypanosoma cruzi. Sua distribuição se dá principalmente nas Américas, desde a Patagônia na Argentina até o sul dos Estados Unidos, porém com a forte imigração de pessoas, áreas que antes eram consideradas não endêmicas estão tendo casos de pessoas infectadas, como na Oceania, Japão, Europa, América do Norte e outros países asiáticos (NEVES, 2016).

Nos anos 70 a doença de Chagas estava presente em 18 Estados brasileiros, incluindo mais de 2.200 municípios. No entanto com os métodos de combate instituídos pela Organização Pan-Americana da Saúde (OPAS) juntamente com os governantes dos países envolvidos, pode-se instalar programas de campanhas de saúde e controle ao combate da doença, o que gerou bons resultados principalmente no aspecto da sua transmissão vetorial (BRASIL, 2012; ARAS et al, 2003). 
Brasil (2017) traz que em 2006 a Organização Pan-Americana da Saúde (OPAS) e a Organização Mundial da Saúde (OMS) concedeu ao Brasil a Certificação da Interrupção da transmissão da doença de Chagas pelo Triatoma infestans considerado o principal vetor domiciliado. Sendo importante destacar que essa certificação não assegura o total controle da doença e nem sua erradicação, se tratando apenas em caráter momentâneo da eliminação da típica espécie Triatoma infestans (FERREIRA e SILVA, 2006).

Galvão et al., (2014) relatam que os principais casos crônicos da doença no Brasil, se tratam de pessoas que adquiriram a doença anos atrás, onde foram infectadas antes de haver o controle do Triatoma infestans, sendo aproximadamente 2 milhões de pessoas as quais adquiriram a doença por meio de infecção vetorial (transmitida pelo vetor). No entanto, recentemente novos casos da fase aguda da doença vêm sendo constatado em diversas partes do país, principalmente na região Amazônica onde a principal forma de infecção se dá por transmissão oral (ingestão de alimentos contaminados).

Segundo o Boletim epidemiológico da Secretaria de Vigilância em Saúde do Ministério da Saúde, foram registrados no Sinan entre os anos de 2012 e 2016 um total de 19.914 casos suspeitos da Doença de Chagas Aguda, sendo que 1.190 equivalente a $5,9 \%$ foram confirmados, e o restante $(94,1 \%)$ descartados. Dentre os casos confirmados 664 eram homens e dentre as mulheres 17 estavam gestantes. A faixa etária dos infectados era correspondente a idade de 20 a 49 anos. Vale ressaltar que dentre os casos confirmados 18 vieram a óbito. Os estados com maiores incidências da doença segundo o Boletim foram o Para e o Amapá, ambos da região norte do país (BRASIL, 2019).

De acordo com BRASIL (2019) os casos confirmados e notificados no sistema de informação de agravos de notificação do Brasil, no ano de 2018 foram de 361 casos registrados da doença de Chagas Aguda no país, número bem maior do que em relação ao ano de 2017 onde teve-se um total de 18 pessoas. Dessas 361 pessoas registradas com a doença, 332 pertenciam a região Norte e as outras 29 a região Nordeste.

Galvão et al. (2014) descrevem que a situação epidemiológica da doença de Chagas no Brasil é representada por dois fatores, sendo eles: a predominância e transmissão da enzootia principalmente pela via oral e os vários casos concentrados existentes na região amazônica. Atualmente a transmissão oral tem sido a principal 
forma de se contrair a doença, cenário que se instalou no Brasil desde 2005 (DIAS et al., 2015).

Brasil (2017) traz que os riscos de transmissão por meio da infecção dos vetores no Brasil persistem por ainda existirem espécies de triatomíneos que possuem elevado índice de infestação e dos mesmos estarem cada vez mais próximos dos seres humanos e de suas residências, como também a permanência do Triatoma infestans em focos residuais existentes em alguns municípios da Bahia e do Rio Grande do Sul.

\subsubsection{Situação epidemiológica no Estado de Goiás}

O Estado de Goiás, localizado na região Centro-Oeste do Brasil, é um Estado com vasta área territorial e privilégios em recursos hídricos. Representa cerca de $4 \%$ do território nacional, tendo uma área de $340.111,78 \mathrm{~km}^{2}$. É composto por 246 municípios e faz divisa com os Estados de Mato Grosso, Mato Grosso do Sul, Tocantins, Bahia e Minas Gerais. Segundo o último censo do Instituto Brasileiro de Geografia e Estatística (IBGE) no ano de 2010 o Estado de Goiás tinha uma população de aproximadamente 6.004.045 habitantes, tendo uma estimativa para o ano de 2019 de 7.018.354 habitantes (IMB, 2014; IBGE, 2010).

O clima do Estado de Goiás é basicamente tropical, possuindo dois períodos de estações, um chuvoso e outro seco e sua vegetação predominantemente é o cerrado. A economia é baseada na atividade agropecuária e o território populacional é evidenciado por possuir áreas de baixas e altas concentrações (IMB, 2014).

Oliveira e Silva (2007) trazem que mesmo após o Estado de Goiás ter recebido a certificação da erradicação do Triatoma infestans, medidas de controle ainda são necessárias, devido a captura de outras espécies que se destacam epidemiologicamente no Estado, como o Triatoma sordida e o Rhodnius neglectus que estão presentes em quase todos os municípios goianos.

FIOCRUZ (2018) relata que desde 2013 a doença de Chagas crônica é de notificação obrigatória, e até o início do ano de 2016 foram notificados cerca de 1.540 casos da doença na fase crônica no Estado, sendo importante ressaltar que a média de óbitos decorrentes dessa infecção é de 750 pessoas por ano.

O Boletim Epidemiológico emitido pelo Ministério da Saúde, traz que entre os anos de 2012 a 2016 foram registrados 3 casos confirmados da Doença de Chagas na 
fase Aguda no Estado de Goiás. Porém nos anos de 2017 e 2018 não se teve nenhum registro da doença no estado (BRASIL, 2019).

A ausência de casos da doença de Chagas no Estado comprova que as medidas de controle e transmissão dessa infecção tiveram sucesso, principalmente com relação a redução de vetores como por exemplo a erradicação do Triatoma infestans que ocorreu no ano de 2000 (MONCAYO e SILVEIRA, 2009; SILVEIRA, 2011).

Costa (2015) menciona que existe uma escassez muito grande de dados recentes na literatura sobre os aspectos epidemiológicos da doença de Chagas no Estado de Goiás, como também a dificuldade em acessar dados nas redes públicas de saúde dos municípios, o que aponta para um sistema de informação mal organizado e pouco integrado.

\subsection{Medidas de Prevenção e Controle da Transmissão da Doença}

A prevenção da doença de Chagas juntamente com formas de controle, está diretamente ligado com as maneiras de transmissão dela. Para o combate e controle da transmissão vetorial é necessário aplicar práticas de higiene e medidas corretas onde existe a infestação dos barbeiros, como manter quintais limpos, manter criações de pequenos animais afastadas das residências, não usar folhas de palmeiras em coberturas de casas, cobrir frestas e rachaduras nas paredes, sendo relevante, orientar os moradores que se caso encontrarem algum inseto é de suma importância não esmaga-los ou danifica-los, protegendo as mãos com luvas ao realizar o manuseio dos mesmos, sendo de importância usarem proteções individuais ao realizarem trabalhos noturnos como roupas de manga longa e repelente. (BRASIL, 2017).

Brasil (2017) traz que quanto a transmissão oral é necessário intensificar medidas de inspeção e vigilância sanitária em todas as fases de produção de alimentos que estão sujeitos a contaminação pelo Trypanosoma cruzi, especialmente nos locais onde se manipulam os alimentos, fazer o uso de iluminações afastadas dos equipamentos utilizados nos processamentos afim de evitar que a luz atraia os vetores, além de implantar programas de capacitação, comunicação e educação com os envolvidos em processamentos alimentícios.

Para Jorge e Castro (2000), um fator essencial que envolve o controle da transmissão vetorial da doença, é primeiramente ensinar a população a conhecer e 
identificar os barbeiros e que eles transmitem uma doença considerada grave, além de instrui-los a encaminhar esses insetos a unidades de saúde para que possa ser analisado se estão ou não infectados, colaborando assim na determinação de áreas endêmicas.

Brasil (2017) reforça que é fundamental que a população tenha todas as informações possíveis sobre a doença, principalmente os profissionais de saúde que possuem papel fundamental na orientação da população como no envolvimento das UBS em práticas de treinamentos, educação, capacitação e constante atualização do assunto, além de implantar ações de combate e controle da doença.

\section{REFERÊNCIAS}

ALENCAR, J. E., História Natural da Doença de Chagas no Estado do Ceará. Fortaleza: Imprensa Universitária, Universidade Federal do Ceará, 1987.

APT, W. et al., Infecção congênita por Trypanosoma cruzi em uma área endêmica do Chile: um estudo multidisciplinar. Transações da Sociedade Real de Medicina Tropical e Higiene, Londres, v. 107, n. 2, p. 98-104, 2013.

ARAS, R. et al., Transmissão vetorial da doença de Chagas em Mulungu do Morro, Nordeste do Brasil. Rev. da Sociedade Brasileira de Medicina Tropical, v. 36, n 3, p. 359-363, 2003.

BAIOCCHI, M. N., Negros de Cedro: Estudo Antropológico de um Bairro Rural de Negros em Goiás. São Paulo: Ática, 1983.

BELISÁRIO, et al. Perfil da infestação do vetor Trypanosoma cruzi em Jaboticatubas, Minas Gerais, Brasil, Revista da Sociedade Brasileira de Medicina Tropical, Uberaba, v. 46, n. 6, p. 779-782, 2013.

BRASIL. Guia de vigilância epidemiológica, Ministério da Saúde, Secretaria de Vigilância em Saúde, Departamento de Vigilância Epidemiológica, 7ạ ed., Brasília, 2009.

BRASIL. Ministério da Saúde. Portal da Saúde. Aspectos epidemiológicos. Secretaria de Vigilância em Saúde. 2012.

BRASIL. Boletim Epidemiológico, Doença de Chagas aguda no Brasil: série histórica de 2000 a 2013, Ministério da Saúde, Secretaria de Vigilância em Saúde. v.46, 2015.

BRASIL. Ministério da Saúde. Secretaria de Vigilância em Saúde. Coordenação-Geral de Desenvolvimento da Epidemiologia em Serviços. Guia de Vigilância em Saúde, v. 3, 1a.. ed., Brasília, 2017. 
BRASIL. Secretaria de Vigilância em Saúde; Ministério da Saúde. Boletim Epidemiológico. Doença de Chagas Aguda e distribuição espacial dos triatomíneos de importância epidemiológica, Brasil 2012 a 2016. v. 50, 2019.

BRASIL. Doença de Chagas Aguda. Casos confirmados Notificados no Sistema de Informação de Agravos de Notificação, Período 2018, DATASUS, 2019. Disponível em: <http://tabnet.datasus.gov.br/cgi/tabcgi.exe?sinannet/cnv/chagasbr.def> Acesso em 14/11/2019.

CARCAVALLO, R. U. et al., Triatoma jurbergi sp. n. do norte do Estado do Mato Grosso, Brasil (Hemiptera, Reduviidae, Triatominae) com uma atualização das sinonímias e outros táxons. Mem. Inst. Oswaldo Cruz 93: 459-464, 1998.

Costa, M. L. Panorama Atual da Doença de Chagas no Estado de Goiás, 2015.

COURA, J. R., Doença de Chagas: o que é conhecido e o que é necessário, um artigo de base. Memórias do Instituto Oswaldo Cruz, Rio de Janeiro, v. 102. p. 113-122, 2007.

COURA, J. R., Os principais cenários de transmissão da doença de Chagas. Os vetores, sangue e transmissões orais - Uma revisão abrangente, Memórias do Instituto Oswaldo Cruz, v. 110, n. 3, p. 277-282, 2015.

COUTINHO, M.; DIAS, J. C. P. A descoberta da doença de Chagas. Cadernos de Ciência \& Tecnologia, 16.2: 11-51, 1999.

DE GRADUAÇÃO, VICE-REITORIA DE ENSINO. Universidade Castelo Branco. Artropodologia e Malacologia. Rio de Janeiro: UCB, 2007.

DE OLIVEIRA, R. L.; CONDURU, R. Nas frestas entre a ciência e a arte: uma série de ilustrações de barbeiros do Instituto Oswaldo Cruz. História, Ciências, Saúde, Manguinhos, 2004.

DE OLIVEIRA, A.W.S.; DA SILVA, I.G. Distribuição geográfica e indicadores entomológicos de triatomíneos sinantrópicos capturados no estado de Goiás. Revista Brasileira de Medicina Tropical. v. 40, no 2, p: 204-208. 2007.

DIAS, J. C. P. Vigilância epidemiológica em doença de Chagas. Caderno de Saúde Pública, v. 16, p. $43-59,2000$.

Dias J. C. P., Doença de Chagas, ambiente, participação e Estado. Cad. Saúde Pública 17: 165-169, 2001

DIAS, J. C. P., Doença de Chagas e transfusão de sangue no Brasil: vigilância e desafios. Revista Brasileira de Hematologia e Hemoterapia, São Paulo, v. 28, n. 2, p. 81-87, 2006. 
DIAS, J. V. L. et al., Fatores envolvidos na distribuição de triatomíneos e seu controle no município de Diamantina, Minas Gerais, Brasil, entre 2011 e 2014. Tese de Doutorado, 2015.

DUARTE, C. L. et al., Estudo dos Triatomíneos (Hemiptera: Reduviidae) recebidos no laboratório de entomologia do centro de controle de zoonoses no município de Rondonópolis-MT. Biodiversidade, v. 16, n. 1, 2017.

DUMONTEIL. E. et al., A distribuição geográfica de Triatoma dimidiata e transmissão dinâmica do Trypanosoma cruzi na península de Yucatán, no México. Sociedade Americana de Medicina Tropical e Higiene, v. 67, 2ª ed. pag. 176 - 183, 2002.

EMBRAPA. Trypanosoma evansi e Trypanosoma vivax: biologia, diagnóstico e Controle, Silva R. A. M. S. et al., Corumbá: Embrapa Pantanal, 2002.

FALCONE, R. Estudo de populações de Rhodnius neglectus e R. prolixus (Hemiptera, Reduviidae, Triatominae) mantidas em laboratório por meio de marcadores mitocondriais, morfológicos e morfométricos, 2016.

FERREIRA, I.L.M.; SILVA, T.P.T. Eliminação da transmissão da doença de Chagas pelo Triatoma infestans no Brasil: um fato histórico. Revista da Sociedade Brasileira de Medicina Tropical. v. 39, n 5, p. 507-509. 2006.

FIOCRUZ - Editores: JUNQUEIRA, A. C. V. et al., Manual de Capacitação na Detecção de Trypanosoma cruzi para Microscopistas de Malária e Laboratoristas da Rede Pública, 2ae ed., 2011.

FIOCRUZ - Editores: JURBERG, J. et al., Laboratório Nacional e Internacional de Referência em Taxonomia de Triatomíneos. Instituto Oswaldo Cruz. Vetores da doença de Chagas no Brasil, 4ae ed., 2015.

FIOCRUZ - Autores: RAMOS, V. P. et al., Políticas de Controle e Notificação da Doença de Chagas: enfrentando o silêncio epidemiológico com a notificação dos casos crônicos, 2018. Disponível em: <http://chagas.fiocruz.br/notificacao/> acesso em $15 / 10 / 2019$

FORATINI, O. P., Biogeografia, origem e distribuição da domiciliação de triatomíneos domiciliares na região central do Brasil. Revista de Saúde Pública, 1980.

GALDINO, Y.; SILVA, C. J., Casa e Paisagem Pantaneira. Cuiabá: Carlini \& Caniato, 2009.

GALVÃO, C. et al., Vetores da doença de chagas no Brasil. Curitiba: Sociedade Brasileira de Zoologia, 289 p., 2014.

IBGE, Instituto Brasileiro de Geografia e Estatística. Resultados do censo 2010. Disponível em: <https://www.ibge.gov.br/estatisticas/sociais/populacao/9662- 
censo-demografico-2010.html?edicao=9749\&t=downloads $>$ acesso em 14 de Novembro de 2019.

IMB, Instituto Mauro Borges de Estatísticas e Estudos Socioeconômicos. Atlas do Estado de Goiás, Goiânia, 2014.

JORGE, T. C.; CASTRO, S. L., Doença de Chagas: Manual para experimentação animal. 2000.

JURBERG, J.; GALVÃO, C., Biologia, ecologia e sistemática dos vetores de Triatominae (Heteroptera, Reduviidae) da doença de Chagas e implicações para a saúde humana, 2006.

LIMA-COSTA Insetos do Brasil. Escola Nacional de Agricultura, 1952.

LIMA-COSTA, M. F. et al., Tendência da mortalidade entre idosos brasileiros (19802000). Epidemiologia e Serviços de Saúde. v. 13, no 217-228, 2004.

MELLO, F., Estudo morfológico dos ovos e ninfas de triatoma dimidiata (Latreille, 1811) vistos através de microscopia óptica e eletrônica de varredura (hemiptera, reduviidae, triatominae), 2008.

MONCAYO, A.; SILVEIRA, A. C., Tendência epidemiológica atual da doença de Chagas na América Latina e desafios futuros em epidemiologia, vigilância e políticas saudáveis. Memórias do Instituto Oswaldo Cruz. Vol, 104, p: 17-30. 2009.

NEVES, D. P. et al., Parasitologia Humana. 13a ed. São Paulo: editora Atheneu, 2016.

OLIVEIRA, A. W. S.; SILVA, I. G., Distribuição geográfica e indicadores entomológicos de triatomíneos sinantrópicos capturados no Estado de Goiás. Revista da Sociedade Brasileira de Medicina Tropical. Vol, 40, no2, p: 204-208, 2007.

OMS. Organização Mundial de Saúde. Doença de Chagas (Tripanossomíase Americana), 2019. Disponível em: <https://www.who.int/en/news-room/factsheets/detail/chagas-disease-(american-trypanosomiasis)\#> acesso em 24/09/2019

PAULA, M. B. C. et al., Ocorrência de positividade para Trypanosoma cruzi em triatomina de municípios do sul do Brasil, de 2002 a 2004. Revista da Sociedade Brasileira de Medicina Tropical, Uberaba, v. 43, n. 1, p. 9-14, 2010.

PINTO DIAS, J. C., Doença de chagas humana e migração no contexto da globalização: alguns aspectos particulares. Revista de medicina tropical, v. 2013, 2013

PONTES, G. B., Comportamento sexual de Rhodnius prolixus. (Heteroptera: Reduviidae), Belo Horizonte, 2010. 
PRATA, A. Aspectos clínicos e epidemiológicos da doença de Chagas. As doenças infecciosas, v. 1, n. 2, p. 92-100, 2001.

RASSI-JUNIOR, A. et al., Doença de Chagas, Londres, v. 375, p. 1388-1402, 2010

SANTANA, K. S. O. et al., Presença de ninfas de Triatoma tibiamaculata em peridomicilos em Salvador, Bahia. Revista de Patologia Tropical, v. 42, n 4, p: 455-458, 2013.

SANTOS-JÚNIOR, J. E. et al., Avaliação de focos naturais de Panstrongylus megistus em um fragmento florestal em Porto Alegre, Rio Grande do Sul, Brasil, Revista da Sociedade Brasileira de Medicina Tropical, Uberaba, v. 46, n. 5, p. 575-583, 2013.

SEGOVIA, M. et al., Rastreamento de fontes epidemiológicas moleculares da doença de Chagas transmitida por via oral, Venezuela. Doenças Infecciosas Emergentes. Atlanta, v. 19, n. 7, p. 1098-1101, 2013.

SILVA, M. J., Parque das emas: última pátria do cerrado. Goiânia, Kelps, 2005.

SILVA, M. J., Quilombos do Brasil Central: Violência e Resistência Escrava 1919-1888. Goiânia: Kelps, 2003.

SILVA, R. M., Isolamento e caracterização de fucosidases digestivas em Arachnida. PhD Thesis, Universidade de São Paulo, 2010.

SILVEIRA, A. C., Novos desafios e o futuro do controle. Revista da Sociedade Brasileira de Medicina Tropical. Vol. 44, no 2, p: 122-124, 2011.

SOTO, H. et al. Investigação de vetores e reservatórios em Chagas agudo por transmissão oral possível em Aguachica, Cesar, Colômbia. Cadernos de Saúde Pública, Rio de Janeiro, v. 30, n. 4, p. 746-756, 2014.

SOUZA-LIMA, R. C. et al., Surto de doença de Chagas aguda associada à transmissão oral na região do Rio Negro, Amazônia Brasileira. Rev. Soc. Bras. Med. Trop., Uberaba, v. 46, n. 4, p. 510-514, 2013.

TAYLOR, M. A. et al., Parasitologia veterinária, tradução José Jurandir Fagliari, Thaís Gomes Rocha, 4a ed., Rio de Janeiro, Guanabara Koogan, 2017.

THIAGO, F., A Comunidade Quilombola do Cedro, Mineiros, Goiás: etnobotânica e educação ambiental, Cáceres-MT: UNEMAT, 2011.

VALENTE, V. C., Estudo genotípico de Trypanossoma cruzi: epidemiologia e caracterização molecular de isolados do homem, triatomíneos e mamíferos silvestres do Pará, Amapá e Maranhão, Tese. Universidade Federal do Pará, 2011. 
VILLELA M. M. et al., Vigilância entomológica da doença de Chagas na região CentroOeste de Minas Gerais, Brasil, entre os anos de 2000 e 2003. Cad Saude Publica, 2005.

WHO, WORLD HEALTH ORGANIZATION et al., Prioridades de pesquisa para doença de Chagas, tripanossomíase humana africana e leishmaniose. World Health Organization, 2012.

WHO, WORLD HEALTH ORGANIZATION, Doença de Chagas (Tripanossomíase Americana), 2019. Disponível em: <https://www.who.int/en/news-room/factsheets/detail/chagas-disease-(american-trypanosomiasis)\#> Acesso em 10/10/2019.

ZELEDON, R. O., Triatoma dimidiata e sua relação com a enfermaria de Chagas. Ed. Universidad Estatal a Distância (UNED), São José, Costa Rica, 1981. 


\section{PRINCIPAIS DOENÇAS INFECCIOSAS E PARASITÁRIAS DE IMPORTÂNCIA EM MEDICINA VETERINÁRIA REVISÕES DE LITERATURA}




\section{PRINCIPAIS DOENÇAS INFECCIOSAS E PARASITÁRIAS DE IMPORTÂNCIA EM MEDICINA VETERINÁRIA REVISÕES DE LITERATURA}

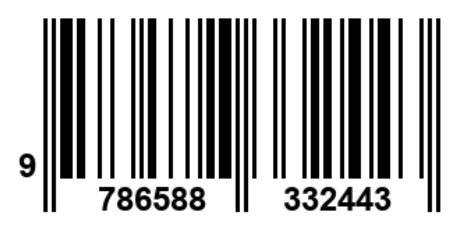

